\title{
Wpływ unijnej \\ polityki regionalnej \\ na zrównoważony rozwój \\ euroregionów zachodniego \\ pogranicza Polski
}


畒 


\section{Ekonomia}

\section{Wpływ unijnej}

polityki regionalnej

na zrównoważony rozwój

euroregionów zachodniego

pogranicza Polski

Anna Misztal 
Anna Misztal - Uniwersytet Łódzki, Wydział Ekonomiczno-Socjologiczny

Zakład Analizy i Strategii Przedsiębiorstwa, 90-214 Łódź, ul. Rewolucji 1905 r. nr 41

\author{
RECENZENT \\ Dariusz Nowak \\ REDAKTOR INICJUJĄCY \\ Monika Borowczyk \\ REDAKTOR \\ Magdalena Kacicka \\ Bogusława Kwiatkowska \\ SKŁAD I ŁAMANIE \\ Monika Wolska \\ KOREKTA TECHNICZNA \\ Leonora Wojciechowska \\ PROJEKT OKŁADKI \\ Stämpfli Polska Sp. z o.o.
}

Zdjęcie wykorzystane na okładce: (C) Shutterstock.com

Wydrukowano z gotowych materiałów dostarczonych do Wydawnictwa UŁ

C Copyright by Anna Misztal, Łódź 2016

(C) Copyright for this edition by Uniwersytet Łódzki, Łódź 2016

Wydane przez Wydawnictwo Uniwersytetu Łódzkiego

Wydanie I. W.07819.16.0.M

Ark. druk. 13,375

ISBN 978-83-8088-650-6

e-ISBN 978-83-8088-651-3

Wydawnictwo Uniwersytetu Łódzkiego

90-131 Łódź, ul. Lindleya 8

www.wydawnictwo.uni.lodz.pl

e-mail: ksiegarnia@uni.lodz.pl

tel. (42) 6655863 


\section{Spis treści}

Wstęp

Rozdział 1

Problematyka rozwoju regionalnego w Unii Europejskiej

1.1. Uwagi wstępne

1.2. Region, regionalizm, regionalizacja - konceptualizacja pojęć 13

1.3. Istota rozwoju regionalnego 21

1.4. Rozwój zrównoważony - nowe podejście do problematyki regionalnej 23

1.5. Teoretyczne koncepcje źródeł zróżnicowania regionalnego 27

1.6. Regiony w Unii Europejskiej 34

1.6.1. Procesy kształtowania się regionów w Unii Europejskiej 35

1.6.2. Przestrzenne zróżnicowanie poziomu rozwoju regionalnego w Unii Europejskiej 36

$\begin{array}{ll}\text { 1.6.3. Współczesne uwarunkowania rozwoju regionalnego } & 37\end{array}$

1.7. Uwagi końcowe $\quad 39$

Rozdział 2

Instrumenty finansowe unijnej polityki regionalnej dla rozwoju regionów

2.1. Uwagi wstępne $\quad 41$

2.2. Polityka regionalna Unii Europejskiej - rys historyczny, uwarunkowania, implikacje $\quad 41$

2.2.1. Geneza i rozwój polityki regionalnej - wczoraj i dziś 42

2.2.2. Strategia Europa $2020 \quad 47$

2.2.3. Polityka regionalna Unii Europejskiej na lata 2014-2020 49

2.2.4. Zasady polityki regionalnej 51

2.3. Instrumenty finansowe polityki regionalnej 52

2.3.1. Europejski Fundusz Rozwoju Regionalnego (EFRR) 53

2.3.2. Europejski Fundusz Społeczny 54

2.3.3. Europejski Fundusz Orientacji i Gwarancji Rolnej 55

2.3.4. Finansowy Instrument Orientacji Rybołówstwa 55

2.3.5. Fundusz Spójności 56 
2.4. Inicjatywy Wspólnotowe jako narzędzie dla zrównoważonego rozwoju euroregionów 57

2.5. Rola polityki regionalnej Unii Europejskiej w niwelowaniu różnic rozwojowych

2.6. Uwagi końcowe

Rozdział 3

Euroregion jako szczególna forma współpracy transgranicznej

3.1. Uwagi wstępne

3.2. Współpraca transgraniczna - pojęcie, cele, zakres

3.2.1. Konceptualizacja pojęcia współpraca transgraniczna

3.2.2. Geneza i podstawy prawne europejskiej współpracy transgranicznej 67

3.2.3. Formy współpracy transgranicznej

3.3. Euroregion, euroregionalizacja - ujęcie teoretyczne $\quad 71$

$\begin{array}{ll}\text { 3.3.1. Euroregion - definicja, cele, struktura organizacyjna } & 71\end{array}$

$\begin{array}{ll}\text { 3.3.2. Uwarunkowania rozwoju euroregionów } & 75\end{array}$

$\begin{array}{ll}\text { 3.3.3. Finansowanie działania euroregionów } & 77\end{array}$

3.3.4. Instytucjonalne uwarunkowania rozwoju regionów $\quad 79$

3.4. Współpraca transgraniczna jako wyznacznik rozwoju regionów 81

3.5. Uwagi końcowe 83

Rozdział 4

Implementacja idei trwałego i zrównoważonego rozwoju w euroregionach

4.1. Uwagi wstępne $\quad 85$

4.2. Geneza euroregionów 85

4.3. Euroregionalizacja w Europie Środkowo-Wschodniej-specyfika tworzenia i funkcjonowania

4.4. Euroregionalizacja w Polsce

4.5. Realizacja koncepcji rozwoju zrównoważonego w polskich euroregionach - warunki, efekty

4.5.1. Efekty współpracy euroregionalnej na pograniczu zachodnim 94

4.5.2. Efekty współpracy euroregionalnej na pograniczu południowym 99

4.5.3. Efekty współpracy euroregionalnej na pograniczu wschodnim i północnym 104

$\begin{array}{ll}\text { 4.6. } & \text { Uwagi końcowe } \\ \end{array}$

Rozdział 5

\section{Uwarunkowania wdrażania koncepcji zrównoważonego rozwoju w euroregionach na zachodniej granicy Polski}

5.1. Uwagi wstępne 109

5.2. Euroregiony na pograniczu zachodnim - geneza, struktura 109

5.3. Diagnoza sytuacji gospodarczej, społecznej i ochrony środowiska naturalnego 113

$\begin{array}{ll}\text { 5.3.1. Położenie euroregionów } & 113\end{array}$

$\begin{array}{ll}\text { 5.3.2. Środowisko naturalne } & 114\end{array}$ 
5.3.3. Potencjał ludzki i warunki życia mieszkańców 116

$\begin{array}{ll}\text { 5.3.4. Instrastruktura i przemysł } & 126\end{array}$

$\begin{array}{ll}\text { 5.3.5. Rolnictwo i turystyka } & 128\end{array}$

5.4. Wybrane inicjatywy euroregionów na rzecz rozwoju przedsiębiorczości i klastrów $\begin{array}{ll}\text { na zachodniej granicy Polski } & 132\end{array}$

5.5. Uwagi końcowe 136

Rozdział 6

Potencjał i cele ekorozwoju w euroregionach na zachodnim pograniczu Polski

$\begin{array}{ll}\text { 6.1. Uwagi wstępne } & 137\end{array}$

$\begin{array}{ll}\text { 6.2. Cele euroregionów } & 137\end{array}$

$\begin{array}{ll}\text { 6.2.1. Kohezja gospodarcza, społeczna i ekologiczna } & 139\end{array}$

6.2.2. Edukacja i świadomość ekologiczna 140

$\begin{array}{ll}\text { 6.2.3. Rozwój przedsiębiorczości } & 141\end{array}$

6.2.4. Racjonalne wykorzystanie zasobów środowiska naturalnego 143

6.3. Analiza potencjału rozwojowego euroregionów 144

6.4. Ocena spójności społecznej, gospodarczej i ekologicznej w euroregionach 146

6.5. Doświadczenia euroregionów na zachodniej granicy Polski 154

$\begin{array}{ll}\text { 6.6. Uwagi końcowe } & 159\end{array}$

Rozdział 7

Analiza wpływu funduszy unijnych na zrównoważony rozwój euroregionów

161

7.1. Uwagi wstępne 161

7.2. Instrumenty finansowe Unii Europejskiej wspierające zrównoważony rozwój euro$\begin{array}{ll}\text { regionów zachodniego pogranicza Polski } & 161\end{array}$

7.3. Statystyczna ocena wpływu unijnych funduszy regionalnych na zrównoważony rozwój euroregionów 163

7.3.1. Metodyka badań 164

$\begin{array}{ll}\text { 7.3.2. Wyniki badań } & 169\end{array}$

$\begin{array}{ll}\text { 7.4. Uwagi końcowe } & 185\end{array}$

$\begin{array}{ll}\text { Zakończenie } & 187\end{array}$

$\begin{array}{ll}\text { Bibliografia } & 191\end{array}$

$\begin{array}{ll}\text { Spis schematów } & 209\end{array}$

$\begin{array}{ll}\text { Spis tabel } & 211\end{array}$

$\begin{array}{ll}\text { Spis wykresów } & 213\end{array}$ 



\section{Wstęp}

W naukach ekonomicznych istnieje szereg zjawisk i problemów badawczych, które pomimo prób ich kwantyfikacji, opisu i naukowego wyjaśniania pozostają wielowymiarowe i nie znajdują jednolitych rozwiązań. Zagadnienia wyrównywania dysproporcji i rozwoju regionalnego są niezwykle interesującym problemem badawczym. Rozwój jest procesem złożonym i długotrwałym, u którego podstaw leży duże przestrzenne zróżnicowanie, które jest naturalną konsekwencją funkcjonowania każdego społeczeństwa. Zróżnicowanie poziomu rozwoju regionów oraz kwestie spójności społeczno-gospodarczej stanowią jeden z ważniejszych aspektów integracji w ramach kontynentu europejskiego.

Szczególnym rodzajem regionów są regiony transgraniczne, często określane mianem peryferyjnych lub opóźnionych. Ich położenie wzdłuż granic państwowych powoduje, że charakteryzują się niższym poziomem rozwoju społeczno-gospodarczego. Istotną rolę w polityce Unii Europejskiej zajmuje współpraca transgraniczna, która dąży do eliminacji negatywnych skutków istnienia granic państwowych oraz zapewnienia trwałego i zrównoważonego rozwoju obszarów transgranicznych. Stanowi ona swego rodzaju odpowiedź na konflikty, które pojawiały się w historii, i jest czynnikiem wpływającym na rozwój i pogłębianie procesów integracyjnych w Europie.

Euroregiony wywodzą się ze współpracy transgranicznej i stanowią jej zinstytucjonalizowaną formę, ukierunkowaną na współpracę w ściśle określonych dziedzinach. Ich celem jest podnoszenie poziomu i jakości życia mieszkańców, rozwój gospodarczy, zapobieganie klęskom żywiołowym, wymiana kulturowa, nawiązywanie relacji pomiędzy szkołami i instytucjami publicznymi.

W literaturze przedmiotu problematyka euroregionalna jest analizowana głównie pod kątem gospodarczego, społecznego i kulturowego wpływu instytucji euroregionalnych na rozwój terenów przygranicznych. Brakuje natomiast analizy wdrażania koncepcji zrównoważonego rozwoju przez euroregiony i badania wpływu środków z funduszy polityki regionalnej Unii Europejskiej na zapewnienie ich trwałego i zrównoważonego rozwoju. 
Podstawowym celem monografii jest przedstawienie roli unijnej polityki regionalnej w zapewnieniu zrównoważonego rozwoju euroregionów. Zasadność regionalnego ujmowania koncepcji zrównoważonego rozwoju wiąże się z integralnością środowiska przyrodniczego i wykraczaniem poza kompetencje poszczególnych gmin problemów związanych z terenami chronionymi, gospodarką wodną, gospodarką odpadami, ograniczeniem zanieczyszczeń.

Efektywność współpracy euroregionalnej w dużej mierze zależy od posiadanych środków finansowych, $\mathrm{z}$ tego wynika ogromna rola narzędzi polityki regionalnej ukierunkowanych na przekazywanie środków finansowych na realizację wspólnych projektów gospodarczych, społecznych i z zakresu ochrony środowiska naturalnego. W tym kontekście hipoteza główna pracy została sformułowana następująco: Fundusze unijnej polityki regionalnej mają istotny wpływ na zrównoważony rozwój euroregionów.

$\mathrm{W}$ toku wywodów podjęto również próbę odpowiedzi na następujące pytania badawcze:

- Czy realizacja koncepcji zrównoważonego i trwałego rozwoju na poziomie regionalnym jest konsekwencją wzrostu roli i znaczenia regionów w Unii Europejskiej?

- Czy ewolucja instrumentów finansowych unijnej polityki regionalnej wpływa na efektywność ich wykorzystania w regionach?

- Czy euroregion dzięki odpowiedniej strukturze organizacyjnej i realizowanym strategiom przyczynia się do aktywizacji terenów przygranicznych?

- Jaką rolę odgrywają euroregiony w realizacji zrównoważonego rozwoju?

- Czy euroregion jest podstawowym ogniwem strategii tworzenia MŚP oraz kreowania sieci współpracy pomiędzy podmiotami gospodarczymi w regionach transgranicznych?

- Czy instrumenty finansowe unijnej polityki regionalnej przyczyniają się do zrównoważonego rozwoju euroregionów?

Monografia ma charakter teoretyczno-empiryczny. Realizacja celu badawczego wymagała zastosowania metody retrospektywnego i krytycznego przeglądu wyselekcjonowanej polskiej i anglojęzycznej literatury przedmiotu (zwartej i czasopiśmienniczej), analizy przyczynowo-skutkowej oraz analizy dokumentów źródłowych, aktów prawnych, danych statystycznych. Podstawową metodą badawczą stosowaną w publikacji jest metoda dedukcyjna. Analizie poddano euroregiony położone na zachodnim pograniczu Polski, gdyż stanowią one ciekawy obszar badawczy, a ich doświadczenia można przenieść na pozostałe euroregiony.

Układ opracowania podporządkowany został weryfikacji przyjętej hipotezy głównej. Wstęp zawiera syntetyczne wprowadzenie w problematykę badań oraz podstawowe pytania badawcze. Pierwsze cztery rozdziały stanowią próbę przedstawienia podstawowych zagadnień teoretycznych, kolejne trzy poświęcone zostały analizie empirycznej. W zakończeniu przedstawiono podsumowanie przeprowadzonych analiz oraz wnioski wynikające $\mathrm{z}$ całokształtu badań. 
Rozdział 1 ma charakter wstępny, instrumentalny i porządkujący. Poświęcony został problematyce rozwoju regionalnego. Punktem wyjścia dla rozważań była próba określenia podstawowych definicji związanych $\mathrm{z}$ regionem, regionalizacją. Pozwoliły one przejść do omówienia istoty i uwarunkowań, a także przyczyn występowania dysproporcji w rozwoju regionalnym. Przedstawiono koncepcje trwałego i zrównoważonego rozwoju jako nowe podejście do problematyki regionalnej. Końcowe rozważania dotyczą zasadności jej wdrażania na poziomie regionalnym.

$\mathrm{W}$ rozdziale 2 przedstawiono historię i ewolucję polityki regionalnej UE, a także jej rolę w zrównoważonym rozwoju regionów. Celem rozdziału jest ukazanie zmian, jakie miały miejsce w podejściu do kwestii pomocy finansowej z UE dla rozwoju regionów.

W rozdziale 3 opisano rolę współpracy transgranicznej dla integracji i rozwoju obszarów peryferyjnych w Unii Europejskiej oraz uwarunkowania funkcjonowania euroregionów. Końcowe rozważania dotyczą wpływu euroregionów na aktywizację terenów przygranicznych oraz znaczenia polityki regionalnej dla ich dalszego rozwoju.

W rozdziale 4 podjęto próbę określenia zasadności implementacji koncepcji zrównoważonego rozwoju w euroregionach. Idea zrównoważonego rozwoju przedstawiona została w kontekście warunków jej realizacji na poziomie euroregionalnym. Rozważania zawierają szkic euroregionalizacji w Polsce i podstawowe zagadnienia rozwoju współpracy euroregionalnej. W rozdziale przedstawiono efekty współpracy transgranicznej w aspekcie ekonomicznym, społecznym i ochrony środowiska naturalnego na granicach Rzeczpospolitej Polskiej.

W rozdziale 5 opisano uwarunkowania geograficzne, społeczne i ekonomiczne rozwoju euroregionów. Podjęto również próbę ukazania euroregionu jako podstawowego ogniwa strategii tworzenia przedsiębiorstw oraz kreowania współpracy pomiędzy podmiotami gospodarczymi w regionach transgranicznych.

W rozdziale 6 opisano cele euroregionów w zakresie realizacji koncepcji zrównoważonego rozwoju. Podjęto również próbę oceny spójności społecznej, gospodarczej i ekologicznej euroregionów na zachodnim pograniczu Polski. Opisano doświadczenia i bariery współpracy oraz sprecyzowano zalecenia na przyszłość.

Rozdział 7 ma charakter empiryczny. Wstępne rozważania poświęcone zostały analizie unijnej polityki regionalnej wdrażanej w euroregionach zachodniego pogranicza Polski. Stworzono wskaźnik zrównoważonego rozwoju euroregionów oraz przeprowadzono statystyczną analizę wpływu zmiennych cząstkowych na jego poziom z wykorzystaniem wskaźnika korelacji Pearsona oraz statystycznej analizy regresji. Pozwoliło to na stworzenie modelu empirycznego oceny wpływu środków finansowych przekazywanych w ramach unijnej polityki regionalnej na poziom zrównoważonego rozwoju euroregionów.

Wydanie niniejszego opracowania zostało sfinansowane przez Wydział Ekonomiczno-Socjologiczny Uniwersytetu Łódzkiego. Monografia powstała na bazie rozprawy doktorskiej napisanej pod kierunkiem naukowym dr hab. Ma- 
rianny Grety, prof. nadzw. UŁ. Szczególne podziękowania za cierpliwość, serdeczność i pomoc składam na ręce Pani Promotor oraz dr. hab. Krzysztofa Lewandowskiego. Na kształt monografii wpłynęły również sugestie wniesione przez dr. hab. Dariusza Nowaka, prof. nadzw. Uniwersytetu Ekonomicznego w Poznaniu, prof. dr. hab. Sławomira Juszczyka ze Szkoły Głównej Gospodarstwa Wiejskiego oraz prof. dr. hab. Leszka Jasińskiego z Politechniki Warszawskiej. Bardzo serdecznie dziękuję również dr hab. Nataszy Duraj, prof. nadzw. UŁ, prof. dr. hab. Janowi Durajowi oraz wszystkim Pracownikom Zakładu Analizy i Strategii Przedsiębiorstwa za wsparcie oraz cenne uwagi.

Anna Misztal 


\section{Rozdział 1}

\section{Problematyka rozwoju regionalnego w Unii Europejskiej}

\subsection{Uwagi wstępne}

Integracja w Unii Europejskiej oparta została na zasadach solidarności, równości i współpracy poszczególnych narodów w celu zapewnienia trwałego i zrównoważonego rozwoju na kontynencie. Spójność społeczna, gospodarcza i terytorialna od momentu podpisania Traktatu $z$ Maastricht stała się głównym kierunkiem polityk UE. Zmniejszanie dysproporcji w rozwoju poszczególnych regionów uważa się za element pogłębiający procesy integracyjne oraz zapewniający rozwój całego ugrupowania integracyjnego. Celem rozdziału jest udzielenie odpowiedzi na pytanie badawcze: Czy realizacja koncepcji zrównoważonego i trwałego rozwoju na poziomie regionalnym jest konsekwencją wzrostu roli i znaczenia regionów w Unii Europejskiej? Temat niniejszego opracowania wymaga zaprezentowania problematyki rozwoju regionalnego. Punktem wyjścia jest omówienie zagadnień teoretycznych związanych $\mathrm{z}$ regionem, regionalizmem, regionalizacją oraz rozwojem regionalnym. W rozdziale przedstawiono etapy kształtowania się regionów oraz przestrzenne zróżnicowanie poziomu rozwoju regionalnego w Unii Europejskiej.

\subsection{Region, regionalizm, regionalizacja - konceptualizacja pojęć}

Teoretyczne koncepcje regionów zależą od przyjętych kryteriów ich wyodrębniania. Badacze zajmujący się kwestią regionów i ich rozwoju w bardzo różnorodny sposób definiują pojęcie „region”. Bogactwo definicyjne tego terminu powoduje, że w literaturze przedmiotu jest on rozpatrywany w oparciu o różne dane, wskaźniki, teorie i dokumenty. Zagadnienia regionu i regionalizmu są obiektem 
zainteresowania szeregu nauk, w tym: ekonomii, politologii, socjologii, historii, geografii, międzynarodowych stosunków gospodarczych ${ }^{1}$.

Etymologicznie termin „region” wywodzi się z łaciny i pochodzi od słów „regio” - królestwo, „rego” - rządzić. Pierwotnie określał on obszar, który był władany przez jednego, wspólnego władcę ${ }^{2}$. Region jest zjawiskiem niepowtarzalnym, niedającym się wpisać $\mathrm{w}$ jeden powszechnie uznawalny i obowiązujący szablon ${ }^{3}$. $\mathrm{Na}$ uwagę zasługuje fakt, że wraz z postępem myśli ekonomicznej i pojawianiem się nowych nurtów w teorii ekonomii następowała ewolucja w konceptualizacji terminu „region”.

Głównym nurtem u schyłku XIX w. i w pierwszej połowie XX w. było podejście chorologiczne do problematyki regionalnej, u którego podstaw leżała chęć poszukiwania odmienności i różnic w poszczególnych regionach. Dokonywano typologii regionów poprzez kryteria geograficzno-przestrzenne ${ }^{5}$. W latach sześćdziesiątych $\mathrm{XX}$ w. pojawiło się nowe podejście nie tylko do problematyki regionalnej, lecz także do nauki, określane mianem regional science, która jako oddzielna dyscyplina naukowa jest dziełem Waltera Isarda i traktowana jest jako zinstytucjonalizowane podejście do tematyki regionalnej. Podstawą badań prowadzonych w ramach tej koncepcji jest uwzględnienie złożoności i współzależności szeregu zjawisk mających charakter ekonomiczno-społeczny, kulturowy, polityczny ${ }^{6}$. Począwszy od lat 90. XX w. wśród koncepcji definujących termin „region” dominują te, które uznają go za strukturę przestrzenną (region społeczny). W ostatnich latach coraz większą popularność zyskuje podejście humanistyczne (region kulturowy) ${ }^{7}$.

1 W. Jastrzębska, Rola euroregionów i współpracy transgranicznej w procesie integracji europejskiej, Wydawnictwo Uniwersytetu Rzeszowskiego, Rzeszów 2008, s. 95.

2 S. Sala, Wpływ procesów globalizacji na region, "Prace Komisji Geografii Przemysłu”, nr 10/2008, s. 55; W. Kopaliński, Słownik wyrazów obcych i zwrotów obcojęzycznych, Wydawnictwo Wiedzy Powszechnej, Warszawa 1989, s. 434-435.

3 K. Wlaźlak, Rozwój regionalny jako zadanie administracji publicznej, Oficyna Wolters Kluwer Polska, Warszawa 2010, s. 19.

4 I. Sagan, Współczesne studia regionalne - teoria i metodologia, a także praktyka, „Studia Regionalne i Lokalne", nr 2(16)/2004, s. 32.

5 Ibidem, s. 27.

6 Z. Chojnicki, Problematyka metodologiczna studiów regionalnych ,,'Studia Regionalne i Lokalne", nr 4(18)/2004, s. 6-7; A. Świeca, T. Brzezińska-Wójcik, Region w ujęciu geograficznym, [w:] M. Dziekanowska, J. Styka (red.), Region w koncepcjach teoretycznych i diagnozach empirycznych, Wydawnictwo Perfecta Info, Lublin 2008, s. 15-40.

7 K. Kwaśniewski, Słownik etnologiczny. Terminy ogólne, PWN, Warszawa-Poznań 1987, s. 304. 


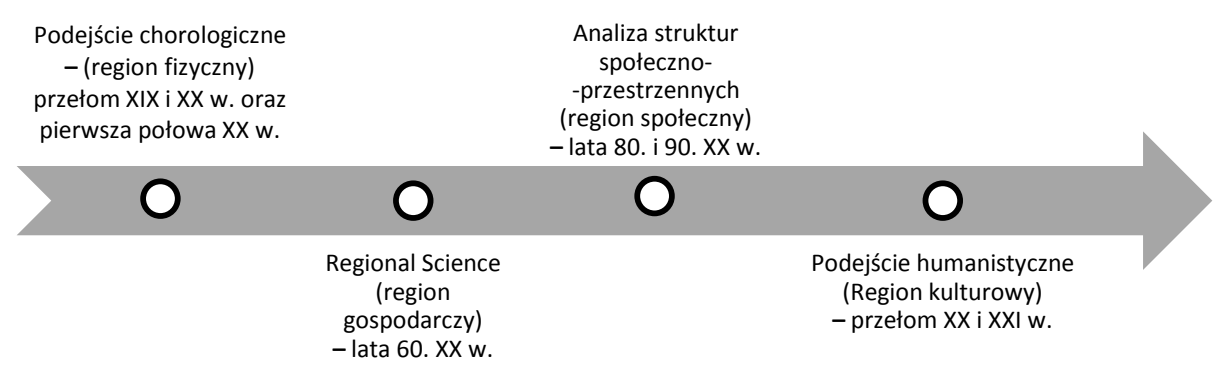

Schemat 1.1. Ujęcia definicyjne "regionu" - zmiany w czasie

Źródło: opracowanie własne na podstawie: I. Sagan, Współczesne studia regionalne - teoria i metodologia, a także praktyka ,"Studia Regionalne i Lokalne", nr 2(16)/2004, s. 25-39.

Determinantami wyróżniającymi poszczególne regiony są pewne indywidualne i reprezentatywne cechy o charakterze geograficznym, społecznym, ekonomicznym i politycznym umożliwiające delimitację danego obszaru ${ }^{8}$.

Przesłanką wyodrębniania regionów geograficznych jest bliskość położenia, występowanie wspólnych cech ukształtowania powierzchni czy zasobów naturalnych'. J.S. Nye uznaje, że „region” to „ograniczona liczba państw, sąsiadujących ze sobą, połączonych pewnym stopniem wzajemnej współzależności” ${ }^{10}$. Zdaniem R. Czarnego oznacza to: „pewien kompleks przestrzenny wyodrębniony na podstawie całego zespołu wzajemnie powiązanych zjawisk polityki międzynarodowej $[\ldots]]^{\prime 11}$.

W naukach politycznych pod pojęciem „region” kryje się największa jednostka podziału administracyjnego kraju, posiadająca osobowość prawną, własne środki finansowe, autonomię w podejmowaniu decyzji. Zazwyczaj w politologii „region” ujmowany jest jako relatywnie duży i jednorodny obszar zamieszkały przez dużą liczbę ludności.

Region socjologiczny, zdaniem A. Kwileckiego, jest „synonimem regionalnej zbiorowości, [...] złączonej mniej lub bardziej rozwiniętym poczuciem odrębności i więzią opartą na emocjonalnym stosunku do zamieszkiwanego terytorium"12.

$8 \quad$ Z. Chojnicki, Region w ujęciu geograficzno-systemowym, [w:] T. Czyż (red.), Podstawy regionalizacji geograficznej, Poznań 1996, s. 24; J. Darmosz, Region i regionalizm (studium interdyscyplinarne), Warszawa 1987, s. 22; S. Sala, op. cit., s. 55.

9 J. Grzela, Region, regionalizm, regionalizacja - wybrane aspekty teoretyczne ,, Studia i Materiały. Miscellanea Oeconomicae", nr 1(15)/2011, s. 15.

10 J.S. Nye, International Regionalism: Readings, Little, Brown \& Co., Boston 1968, s. 6-7.

11 R.M. Czarny, Regionalizm w stosunkach międzynarodowych 1945-75, Wydawnictwo WSP, Kielce 1986, s. 4-5.

12 A. Kwilecki, Region i badania regionalne w perspektywie socjologii, „Ruch Prawniczy, Ekonomiczny i Socjologiczny", z. 2/1992, s. 38. 


\begin{tabular}{|c|c|c|c|}
\hline \multicolumn{4}{|c|}{ Wielowymiarowość pojęcia „region” } \\
\hline $\begin{array}{l}\text { Wymiar polityczno- } \\
\text {-administracyjny } \\
\text { (oddziaływania } \\
\text { o charakterze politycznym } \\
\text { oraz administracyjno- } \\
\text {-prawnym) }\end{array}$ & $\begin{array}{c}\text { Wymiar ekonomiczny } \\
\text { (zjawiska i procesy } \\
\text { gospodarcze } \\
\text { zachodzące w regionie) }\end{array}$ & $\begin{array}{c}\text { Wymiar } \\
\text { społeczno-kulturowy } \\
\text { (ujęcie } \\
\text { antropologiczno- } \\
\text {-aksjologiczne) }\end{array}$ & $\begin{array}{c}\text { Wymiar przestrzenny } \\
\text { (perspektywa } \\
\text { geograficzna, } \\
\text { przyrodnicza } \\
\text { i techniczna) }\end{array}$ \\
\hline
\end{tabular}

Schemat 1.2. Ujęcia definicyjne "regionu" - wielowymiarowość

Źródło: D. Waldziński, Polityka regionalna w Polsce w procesie przemian kulturowo-cywilizacyjnych. Zarys problemu, Wydawnictwo Uniwersytetu Warmińsko-Mazurskiego, Olsztyn 2005, s. 27-35.

"Region ekonomiczny” rozumiany jest jako pewna część terytorium geograficznego, która charakteryzuje się spójnością społeczno-ekonomiczną oraz podobną strukturą zagospodarowania przestrzennego. Wśród kryteriów wyodrębniania regionów ekonomicznych należy wyróżnić: potencjał gospodarczy, strukturę przemysłu, poziom urbanizacji, cyfryzacji, powiązania społeczno-ekonomiczne. „Region ekonomiczny” to: „ukształtowany lub kształtujący się układ ekonomiczny, którego elementy powiązane są między sobą i ze środowiskiem przyrodniczym [...]"13. W ujęciu ekonomicznym „region” to struktura ekonomiczna o przestrzennym charakterze, zbudowana ze sfery realnej, czyli podmiotów gospodarczych, oraz sfery regulacji (władze państwowe i samorządowe) ${ }^{14}$.

Pierwotnie Rada Europy określiła, że „region” to „szczebel poniżej państwa”. Obecnie obowiązująca definicja zawarta została w przedłożonej przez Radę Europy Europejskiej Karcie Samorządu Terytorialnego. M. Kulesza, dokonując syntezy zapisów dokumentu, podkreśla, że region powinien posiadać wspólnotę interesów gospodarczych, władzę pochodzącą z wolnych wyborów, poczucie wspólnej tożsamości obywateli, potrzebę realizacji spraw interesu ogólnego. Powinien również być jednostką terytorialną najwyższego stopnia ${ }^{15}$.

Dla celów statystycznych i ułatwienia realizacji polityki regionalnej władze Unii Europejskiej wprowadziły jednolitą strukturę jednostek terytorialnych, która określana jest jako „nomenklatura jednostek terytorialnych dla celów statystycznych" (The Nomenclature of Territorial Units for Statistics - NUTS). Obecnie wy-

13 R. Domański, Geografia ekonomiczna, PWN, Warszawa 1982, s. 228.

14 M. Wosiek, Współczesna teoretyczna koncepcja regionu ekonomicznego, [w:] A.A. Ткач (red.), Інститучіональний вектор економічного розвитку, „Збірник наукових праць, Випуск", 1(2) МІДМУ "КПУ", s. 131-137.

15 M. Proniewski, Rozwój regionów peryferyjnych w Unii Europejskiej. Wybrane aspekty, Białystok 2012; M. Kulesza, Zasada subsydiarności jako klucz do reform ustroju administracyjnego państw Europy Środkowej i Wschodniej (na przykładzie Polski), [w:] D. Milczarek (red.), Subsydiarność, Centrum Europejskie Uniwersytetu Warszawskiego, Warszawa 1998, s. 124. 
różnia się trzy poziomy nomenklatury opierające się na podziałach administracyjnych i planistycznych ${ }^{16}$.

„Region” w Unii Europejskiej, jak pisze C.T. Szyjko, rozumiany jest jako „konkretny dla danego kraju obecny podział administracyjno-terytorialny [...] z tą jednak uwagą, że należy $\mathrm{w}$ tych przypadkach uwzględnić ustrój państwowy poszczególnych krajów, ich podział na państwa regionalne, federalne i unitarne"17. W państwach regionalnych i federalnych uprawnienia i zadania regionów określone są w konstytucjach, przy czym mają one legitymację do ustanawiania przepisów prawa miejscowego, która nie podlega kontroli władz państwowych. W przypadku państw unitarnych mamy do czynienia z decentralizacją władzy na rzecz regionów. Wykształcony region powinien być podporządkowany władzy centralnej, posiadać wspólnotę interesów ekonomicznych, poczucie wspólnej tożsamości obywateli, władzę pochodzącą z wyborów ${ }^{18}$.

Tabela 1.1. Etapy rozwoju regionalizmu

\begin{tabular}{|l|l|}
\hline $\begin{array}{l}\text { Pojawienie się świadomości } \\
\text { regionalnej }\end{array}$ & $\begin{array}{l}\text { Poczucie przynależności do danego obszaru, wspólnej toż- } \\
\text { samości, opartej o tradycje, kulturę, religię. }\end{array}$ \\
\hline Wspólnota interesów & Pojawienie się wspólnych potrzeb, interesów i możliwości. \\
\hline $\begin{array}{l}\text { Wzrost interakcji pomiędzy } \\
\text { państwami i społecznościami } \\
\text { regionalnymi }\end{array}$ & $\begin{array}{l}\text { Organizacja konferencji regionalnych, stałe relacje pomię- } \\
\text { dzy partnerami, konsultacje w kwestiach istotnych dla roz- } \\
\text { woju regionów. }\end{array}$ \\
\hline Integracja państw regionu & $\begin{array}{l}\text { Integracja ekonomiczna i polityczna mająca na celu liberali- } \\
\text { zacje przepisów ekonomicznych i prawnych. }\end{array}$ \\
\hline
\end{tabular}

Źródło: opracowanie własne na podstawie: E. Haliżak, Regionalizm w stosunkach międzynarodowych, Wydawnictwa Uniwersytetu Warszawskiego, Warszawa 2006, s. 270-280.

Z pojęciem "region” niewątpliwie wiążą się dwa podobnie brzmiące terminy: „regionalizm” i „regionalizacja”. Źródeł regionalizmu należy dopatrywać się we wspólnej historii, tradycji, pochodzeniu etnicznym ${ }^{19}$. Pojęcie „regionalizm” zostało stworzone w 1874 r. przez Leona de Beluc-Perussisa ${ }^{20}$. Prawdziwy rozkwit jednak przeżywało ono pod koniec XIX w., kiedy to narodziła się świadomość odrębności i myślenia kategoriami poszczególnych obszarów. Ma ono charakter polityczny i jest

16 S. Łodziński, Cele i zasady polityki regionalnej w Unii Europejskiej, „Kancelaria Sejmu, Biuro Studiów i Ekspertyz", nr 483/1997, http://biurose.sejm.gov.pl/teksty_pdf_97/i-483.pdf, s. 1 [dostęp 12.07.2016].

17 C.T. Szyjko, Enigma nowego regionalizmu europejskiego, Wydawnictwo i Drukarnia „Złote Myśli", Warszawa 2010, s. 12-13.

18 J. Strzelec, Doświadczenia i wyzwania rozwoju regionalnego w latach 1999-2013 na przykładzie województwa świętokrzyskiego, Wydawnictwo Uniwersytetu Humanistyczno-Przyrodniczego im. Jana Kochanowskiego, Kielce 2010, s. 10.

19 K. Wlaźlak, op. cit., s. 20.

20 J. Damrosz, Region i regionalizm (Studium interdyscyplinarne), Warszawa 1987, s. 81. 
rezultatem pojawienia się ruchów społecznych, dla których poczucie odrębności językowej, kulturowej czy gospodarczej jest niezwykle istotne (Francja, Hiszpania, Włochy, Polska w okresie międzywojennym ${ }^{21}$. Regionalizm administracyjny pojawił się po II wojnie światowej, związane jest to z wprowadzeniem nowych jednostek terytorialnych, jak również decentralizacją władzy na rzecz niższych szczebli samorządu terytorialnego.

$\mathrm{Na}$ przestrzeni lat pojęcie „regionalizmu” ewoluowało i ulegało licznym przekształceniom. Jak piszą T. Czyż i Z. Chojnicki: „pojęcie regionalizmu odnosi się zarówno do stanu świadomości społecznej, [...] jak i do aktywności gospodarczej, kulturowej i politycznej [...] Regionalizm stanowi syndrom różnorodnych własności specyficznych dla zbiorowości ludzi występujących na danym obszarze i określających jego odrębność" ${ }^{22}$. Regionalizm jest zjawiskiem, u którego podstaw leży położenie geograficzne, współzależności polityczne, gospodarcze, kulturowe i historyczne. Jest niejako rezultatem sąsiedztwa i podobieństw w kształcie ustrojów politycznych ${ }^{23}$. K. Chorąży uważa, że regionalizm to: „świadomość istnienia interesów, uznanych za wspólne przez mieszkańców terytorium o charakterze homogenicznym i dążenie do współuczestnictwa w ich realizacji”24. $Z$ definicji tej jednoznacznie wynika, że u podstaw wszystkich działań związanych ze zjawiskiem regionalizmu leżą wspólne interesy oraz chęć podejmowania decyzji odnośnie do realizacji założonych celów.

Definicje regionalizmu przybierają różne formy. Słownik Webster's New World Dictionary pod hasłem „regionalizm” rozumie: „poczucie lojalności społeczności lokalnej wobec obszaru wyróżnionego pod względem symilaryzacji gospodarczej, politycznej, społecznej, ustrojowej i poczucia wspólnej tożsamości [...], jak również kierunek i trend w sztuce, $\mathrm{u}$ którego podstaw leżą sprawy regionalne [...], aż wreszcie podejście badawcze do tematyki regionalnej25”. Bardziej treściwie termin „regionalizm” definiuje McLean w Oksfordzkim słowniku polityki jako: „postępowanie lub podejście dotyczące regionalnej władzy”26. Wzajemna współpraca pomiędzy regionami i państwami oparta została o wspólnotę interesów, podobną kulturę, tradycję, sytuację społeczno-polityczną ${ }^{27}$.

21 A. Kociszewski, Regionalizm mazowiecki, Triada, Warszawa 1993, s. 123-124; Z. Niewiadomski, Samorząd terytorialny, [w:] Z. Niewiadomski (red.), Prawo administracyjne, Warszawa 2007, s. 138-141.

22 Z. Chojnicki, Region w ujęciu geograficzno-systemowym, [w:] T. Czyż (red.), Podstawy regionalizacji geograficznej, Bogucki Wydawnictwo Naukowe, Poznań 1996, s. 30-31.

23 K. Macios, Regionalizm i współpraca regionalna, wos.org.pl [dostęp 10.08.2012].

24 K. Chorąży, Zagadnienia ustroju lokalnego Francji, Lublin 1998, s. 167.

25 Webster's New World Distionary, Chicago 1993, s. 1912.

26 I. McLean, The Concise Oxford Dictionary of Politics, Oxford-New York 1996, s. 424.

27 E. Haliżak, Regionalizm w stosunkach międzynarodowych, [w:] E. Haliżak, R. Kuźniar (red.), Stosunki międzynarodowe. Geneza, struktura, dynamika, Wydawnictwa Uniwersytetu Warszawskiego, Warszawa 2006, s. 269-270. 
Pewne jest, że organizacja współczesnego państwa demokratycznego wymaga przestrzegania przez władze zasady pluralizmu państwowego, decentralizacji władzy i demokracji. Wdrażanie tych zasad wymaga „wieloaspektowej organizacji społecznej, powstawania pomiędzy jednostką a państwem szeregu społeczności pośrednich. [...] rezygnacji ze strony państwa z części swych uprawnień na rzecz niższych społeczności; szerokiego udziału faktycznego społeczeństwa w rządach" ${ }^{28}$. Słowa te dobitnie wskazują na to, że w obrębie jednego państwa powinna mieć miejsce autonomia dla społeczności lokalnych, dla ich odrębności i samorządności.

Współcześnie w literaturze głównego nurtu problematyki regionalnej podkreśla się istnienie dwóch form regionalizmu: oddolnego (bottom-up regionalism) i odgórnego (top-down regionalism ${ }^{29}$. Regionalizm oddolny określany jest jako ruch społeczny, pewien sposób myślenia, poczucie wspólnej tożsamości opartej o regionalne zwyczaje, kulturę, tradycję, religię. Natomiast regionalizm odgórny przejawia się tym, że władze centralne, chcąc działać bardziej efektywnie, przekazują część swoich uprawnień na rzecz samorządów lokalnych ${ }^{30}$.

Unia Europejska przez wielu naukowców uważana jest za najlepszy przykład struktury regionalizacji gospodarki. L. Mączka twierdzi, że regionalizm w wydaniu europejskim stanowi swoistą opozycję dla procesów globalizacji i międzynarodowych organizacji gospodarczych i finansowych ${ }^{31}$. Podkreśla, że procesy regionalizacji prowadzą do wyodrębnienia wielu różnych bloków gospodarczych i politycznych ${ }^{32}$. Meritum regionalizacji gospodarczej jest proces przekształcania struktury gospodarczej wewnątrz integrujących się podmiotów, ale również tworzenie trwałych relacji w celu zbudowania jednolitego organizmu gospodarczego, wyróżniającego się specyfiką i indywidualnością na tle innych. W tym rozumieniu regionalizacja gospodarcza stanowi jeden $\mathrm{z}$ warunków racjonalnego wykorzystania zasobów i osiągnięcia realnego wzrostu gospodarczego ${ }^{33}$.

Regionalizm może być postrzegany $\mathrm{w}$ dwóch aspektach: podmiotowym i przedmiotowym. Aspekt podmiotowy oznacza działalność ludności zamieszkującej dany obszar na rzecz regionu, a zatem podejmowanie wszelkich działań, prowadzących do postępu i rozwoju danego terytorium. W aspekcie przed-

28 C. Strzeszewski, Katolicka nauka społeczna, Ośrodek Dokumentacji i Studiów Społecznych, Warszawa 1985, s. 514.

29 W. Misiuda-Rewera, Włochy. Republika autonomii, Wydawnictwo UMCS, Lublin 2005, s. 58; M. Keating, Is there a regional level of government in Europe?, [w:] P. Le Gales, Ch. Lequense (red.), Regions in Europe, London-New York 1998, s. 14-17.

30 A. Lewandowski, Regionalizmy i lokalizmy, Katowice, europrojekty.pl [dostęp 15.02.2014].

31 T. Skoczek, Wpływ lokalizmu i regionalizmu na media, Kultura, Warszawa 2009, s. 136.

32 L. Mączka, Gospodarka globalna u progu XXI wieku, Wydawnictwo Akademii Ekonomicznej w Krakowie, Kraków 2003, s. 15.

33 R. Pałka, Globalizacja i integracja regionalna a rola państwa, "Gazeta Innowacje”, nr 18/2003, s. 12, http://imik.wip.pw.edu.pl/innowacje18/strona12.htm [dostęp 12.06.2015]. 
miotowym regionalizm dotyczy obszaru wraz z zawartymi w nim bogactwami naturalnymi ${ }^{34}$.

Regionalizm oznacza działania podejmowane w regionach w celu uzyskania autonomii w wybranych dziedzinach życia (działania typu bottom-up) ${ }^{35}$. Kontrastem dla pojęcia "regionalizm” jest termin „regionalizacja” - jak pisze J. Olbrycht, jest ona „działaniem typu top-down” i polega na podejmowaniu i realizacji przez Unię Europejską i państwa członkowskie zadań, które mają na celu rozwój regionów ${ }^{36}$.

"Regionalizacja” jest pojęciem wieloznacznym i może być rozumiana w ujęciu dynamicznym jako działania i czynności bądź też statycznie - jako rezultat ${ }^{37}$. Komitet Regionów określa „regionalizację” jako proces prowadzący do rozwoju określonego obszaru. Może ona zachodzić zarówno w oparciu o już funkcjonujące podmioty lub też (jeżeli jest to uzasadnione merytorycznie) może wymagać utworzenia nowej jednostki terytorialnej ${ }^{38}$.

Regionalizacja, jak pisze M. Cyrek, „obejmuje zjawiska zacieśniania współpracy i upodabniania się struktur $\mathrm{w}$ ramach ugrupowań o mniejszej przestrzennie skali” ${ }^{39}$. Termin „regionalizacja” i „decentralizacja” są pojęciami stosowanymi w zależności od charakteru i typu państwa. W państwach federalnych używa się terminu „regionalizacja”, natomiast w państwach unitarnych „decentralizacja” ${ }^{40}$. W Europie Zachodniej od wielu lat mamy do czynienia z postępem i rozwojem decentralizacji.

Konkludując, można stwierdzić, że regionalizacja jest procesem prowadzącym do uzyskania przez regiony prawa do podejmowania niezależnych decyzji i działań, dotyczących kwestii ich rozwoju. U jej podstaw leży integracja ekonomiczna,

34 H. Skorowski, Antropologiczno-etyczne aspekty regionalizmu, Wydawnictwo Salezjańskie, Warszawa 1990, s. 57-72.

35 Commitee of the Regions, Regional and local democracy in the European Union, Brussels 1999, s. 6.

36 J. Olbrycht, Status regionów a programowanie na poziomie regionalnym, Ekspertyza na zlecenie Departamentu Koordynacji Polityki Strukturalnej w MGPiPS, Warszawa 2004; http://www.funduszestrukturalne.gov.pl, s. 1-2 [dostęp 17.06.2012].

37 B. Woś, Rozwój regionów i polityka regionalna w Unii Europejskiej oraz w Polsce, Oficyna Wydawnicza Politechniki Wrocławskiej, Wrocław 2005, s. 21.

38 European Parliament. Directorate General for Research, Regionalisation in Europe, Working Paper, Regional Policy Series REGI 108aXX, s. 23.

39 M. Cyrek, Procesy upodabniania się struktur gospodarczych Polski i wybranych krajów Unii Europejskiej, "Zeszyty Naukowe Uniwersytetu Rzeszowskiego", nr 8/2006, s. 282.

40 I. Pietrzyk, Polityka regionalna Unii Europejskiej i regiony w państwach członkowskich, Wydawnictwo Naukowe PWN, Warszawa 2002, s. 213; J. Świeca, Regionalizacja i federalizm a ustrojowa kwestia elastyczności europejskich systemów demokratycznych na przykładzie Szwajcarii, Belgii i Niemiec, Wyższa Szkoła Zarządzania i Marketingu w Sosnowcu, Sosnowiec 2004, s. 25. 
poczucie wspólnoty i możliwości jej dalszego społeczno-gospodarczego rozwoju. Zamierzeniem regionalizacji jest zwiększenie znaczenia i roli regionów $\mathrm{w}$ procesie podejmowania decyzji na poziomie krajowym i europejskim ${ }^{41}$.

\subsection{Istota rozwoju regionalnego}

Problematyka rozwoju regionalnego jest złożona i kompleksowa, wymaga podejścia holistycznego ${ }^{42}$. W piśmiennictwie termin „rozwój regionalny” jest różnorodnie definiowany ${ }^{43}$. A.C. Nelson uznaje, że są nim „zmiany w regionalnej produktywności mierzonej wielkością populacji, zatrudnieniem, dochodem i wartością produkcji dodanej. Ponadto obejmuje również rozwój społeczny rozumiany jako poziom opieki zdrowotnej, dobrobyt, jakość środowiska czy kreatywność" ${ }^{4}$. $\mathrm{Na}$ poprawę poziomu i jakości życia wskazuje również definicja traktująca, że jest nim „trwały wzrost poziomu życia mieszkańców i potencjału gospodarczego w skali dużej jednostki terytorialnej”45. Rozwój regionalny oznacza zatem „wzrost potencjału gospodarczego regionów oraz trwałą poprawę ich konkurencyjności i poziomu życia ludności, przyczyniające się do rozwoju społeczno-gospodarczego

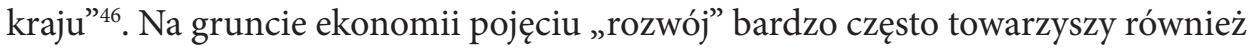
termin „wzrost”. Wzrost gospodarczy dotyczy zwiększania produktu krajowego na jednego mieszkańca, ma on zatem charakter ilościowy. Pojęcie wzrostu jest węższe od pojęcia rozwoju. Rozwój prowadzi nie tylko do zmian ilościowych, ale rów-

41 P. Huber, Regional labour market developments in transition, „The European Journal of Comparative Economics", no 4(2)/2007, s. 6.

42 S. Juszczyk, Korporatyzacja innowacji jako współczesna bariera rozwoju nauk ekonomicznych, „Rocznik Nauk Rolniczych. Seria G. Ekonomika Rolnictwa” 2010, t. 97, z. 2, s. 145; A. Hołuj, D. Korecki, Uwarunkowania rozwoju regionalnego w Polsce, "Zeszyty Naukowe Wyższej Szkoły Ekonomicznej w Bochni", nr 7/2008, s. 23; P. Churski, Czynniki rozwoju regionalnego w świetle koncepcji teoretycznych ,,Zeszyty Naukowe Wyższej Szkoły Humanistyczno-Ekonomicznej we Włocławku. Nauki Ekonomiczne", t. XIX, z. 3/2005, s. 31.

43 Z. Szymla, Podstawy badań rozwoju regionalnego, ,ZZeszyty Naukowe Wyższej Szkoły Ekonomicznej w Bochni", nr 3/2005, s. 101.

44 W. Dziemianowicz, Kapitał zagraniczny a rozwój regionalny i lokalny w Polsce ,,Studia Regionalne i Lokalne", nr 21(54)/1997, s. 29.

45 M. Benio, J. Bober, J. Hausner, S. Kołdras, T. Kudłacz, Ł. Mamica (red.), Programowanie rozwoju regionalnego. Poradnik dla samorządów województwa, Małopolska Szkoła Administracji Publicznej Akademii Ekonomicznej w Krakowie, Kraków 1999, s. 22.

46 M. Kozak, A. Pyszkowski, R. Szewczyk, Słownik rozwoju regionalnego, PARR, Warszawa 2001, s. 46. 
nież jakościowych, które mają charakter niemierzalny. Wzrost jest warunkiem koniecznym i niezbędnym dla pojawienia się rozwoju gospodarczego ${ }^{47}$.

W literaturze głównego nurtu dominującym czynnikiem mającym wpływ na rozwój regionów jest mobilizacja endogenicznego potencjału tkwiącego w regionach. Należy podkreślić, że tak postrzegany rozwój jest rezultatem działań i prac podejmowanych przez społeczności, podmioty gospodarcze i władze regionalne ${ }^{48}$. Rozwój ten, jak pisze B. Woś, „oznacza oddolny sposób generowania dynamiki rozwoju - bazujący na zasobach endogenicznych i wykorzystujący cały wewnętrzny potencjał rozwojowy w różnej skali przestrzennej (»rozwój o różnej geometrii«)”49.

Znamiene jest, że istnienie różnic w poziomie rozwoju poszczególnych regionów uznaje się za obiektywny rezultat funkcjonowania i rozwoju każdego społeczeństwa ${ }^{50}$. Różnice w poziomie rozwoju poszczególnych regionów pozwalają wyodrębnić regiony słabiej i lepiej rozwinięte. Klasyfikacja poszczególnych regionów odbywa się przy uwzględnieniu różnych kryteriów wyboru.

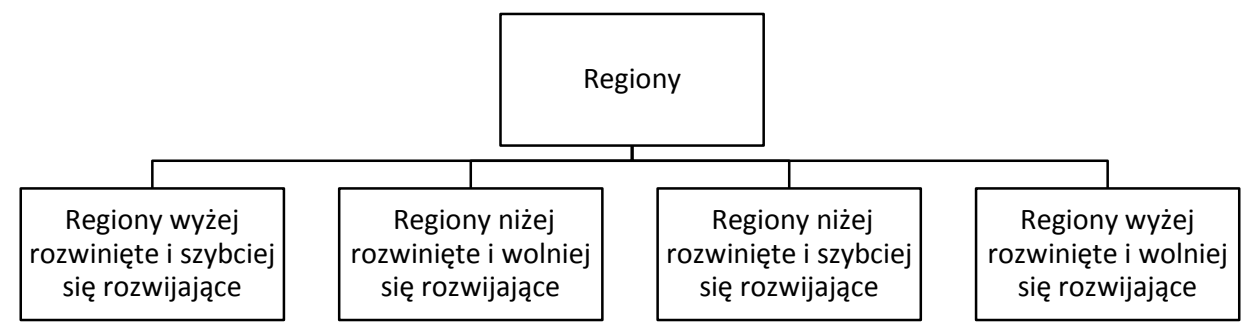

Schemat 1.3. Typologia regionów wg L. Klassena

Źródło: opracowanie własne na podstawie: L. Klassen, Area, Economic and Social Redevelopment, Paris 1965, [za:] Z. Szymla, Podstawy badań nad rozwojem regionalnym, „Zeszyty Naukowe Wyższej Szkoły Ekonomicznej w Bochni", nr 3/2005, s. 103.

A. Kukliński uważa, że rozróżnienie to powinno odbywać się poprzez weryfikację trzech przesłanek: zdolności i wielkości potencjału gospodarczego, efektywności podmiotów gospodarczych, jakości i poziomu życia w regionach ${ }^{51}$. Z kolei L. Klassen wprowadza typologię regionów uwzględniającą poziom i tempo ich

47 P. Churski, op. cit., s. 2

48 E. Pancer-Cybulska, Uwarunkowania samorządności lokalnej i regionalnej w Polsce w aspekcie kreowania i wzrostu konkurencyjności, [w:] M. Klamut (red.), Konkurencyjność regionów, Wydawnictwo Akademii Ekonomicznej we Wrocławiu, Wrocław 1999, s. 220-226.

49 B. Woś, Rozwój regionów..., s. 26-27.

50 Z. Szymla, op. cit., s. 102.

51 A. Kukliński, Gospodarka przestrzenna i studia regionalne. Problemy dyskusyjne, „Biuletyn KPZK PAN", nr 111/1980, s. 75-80. 
rozwoju ${ }^{52}$. G. Gorzelak rozwija typologię Klassena, uwzględniając w niej rozważania dotyczące znaczenia i roli regionów dla rozwoju całego kraju. Wyróżnia on poza regionami silnymi i słabymi, regiony wyzyskiwane i wyzyskujące ${ }^{53}$. Składowymi rozwoju regionalnego są: wzrost gospodarczy i zatrudnienia, poprawa jakości życia mieszkańców, innowacyjność, wdrażanie nowych technologii, rozwój infrastruktury komunikacyjnej, poprawa stanu środowiska naturalnego, wzrost tożsamości regionalnej i postęp procesów integracyjnych ${ }^{54}$.

\subsection{Rozwój zrównoważony - nowe podejście do problematyki regionalnej}

Termin „zrównoważony rozwój” został wprowadzony przez Hansa Carla von Carlowitza i odnosił się do takiego gospodarowania lasem, gdy wycina się ilość drzew, która powinna być zastąpiona nowymi sadzonkami ${ }^{55}$. Nazwa ta przyjęta została przez ruch ochrony środowiska naturalnego i wprowadzona do szerokiej debaty publicznej. Najbardziej rozpowszechnioną, a zarazem jedną z najprostszych definicji zrównoważonego rozwoju zawiera raport przedstawiony przez Komisję Brundtland, zgodnie z którą: „Zrównoważony rozwój to rozwój, który zaspokaja potrzeby obecne, nie zagrażając możliwościom zaspokojenia potrzeb przyszłych pokoleń" 56 . Podobnie zrównoważony rozwój definiuje Organizacja Narodów Zjednoczonych: „Zrównoważony rozwój Ziemi to rozwój, który zaspokaja podstawowe potrzeby wszystkich ludzi [...] bez zagrożenia możliwości zaspokojenia potrzeb przyszłych pokoleń i bez przekraczania długookresowych granic pojemności ekosystemu Ziemi" "57. Zgodnie z koncepcją zrównoważonego rozwoju wzrost gospodarczy przyczynia się do zwiększenia kohezji społecznej i przebiega z uwzględnieniem podnoszenia standardów w zakresie ochrony środowiska naturalnego.

52 L. Klassen, Area, Economic and Social Redevelopment, Paris 1965, [za:] Z. Szymla, Podstawy badań nad rozwojem regionalnym, "Zeszyty Naukowe Wyższej Szkoły Ekonomicznej w Bochni", nr 3/2005, s. 103.

53 G. Gorzelak, Reforma ekonomiczna w Polsce na tle rozwoju regionalnego, „Ekonomista”, nr 1/1989, s. 11.

54 A. Klasik, F. Kuźnik, Konkurencyjny rozwój regionów w Europie, [w:] Z. Szymla (red.), Konkurencyjność miast i regionów, Wydawnictwo Akademii Ekonomicznej w Krakowie, Kraków 2001, s. 23.

55 E. Mazur-Wierzbicka, Koncepcja zrównoważonego rozwoju w praktyce społeczno-gospodarczej Unii Europejskiej, „Ekonomia”, nr 4(21)/2012, s. 36.

56 D. Kiełczewski, Rozwój zrównoważony w skali regionalnej. Środowisko przyrodnicze - czynnik czy bariera rozwoju?, [w:] Zrównoważony rozwój - aspekty rozwoju społeczności lokalnych, Forum Inicjatyw Wspólnotowych, Białystok 2009, s. 29.

57 R. Stappen, Raport Brundtland, New York 2006, s. 27-28. 
W literaturze przedmiotu można znaleźć dwa podejścia do zrównoważonego rozwoju ${ }^{58}$ :

- ekonomiczne, w którym wzrost gospodarczy utożsamiany jest z paradygmatem ochrony środowiska naturalnego,

- ideologiczno-historiozoficzne, skupiające uwagę na nowych zachowaniach i celach społecznych przyczyniających się do rozwoju całej cywilizacji ${ }^{59}$.

Istotą zrównoważonego rozwoju jest współistnienie relacji gospodarczych, społecznych i ochrony środowiska naturalnego poprzez realizację następujących celów:

- gospodarczego, polegającego na zaspokajaniu materialnych potrzeb ludzkich,

- społecznego, zapewnienie minimum socjalnego, zapewnienie pożywienia, ochronę zdrowia, kulturę i edukację,

- ekologicznego, powstrzymaniu degradacji środowiska naturalnego i niwelowaniu zagrożeń związanych z działaniem sił przyrody ${ }^{60}$.

Rozwój, zdaniem T. Borysa, jest „nową filozofią rozwoju globalnego, regionalnego i lokalnego, przeciwstawiająca się wąsko rozumianemu wzrostowi gospodarczemu, wskazująca, że ekorozwój nie może być utożsamiany ani z wąsko rozumianą ochroną środowiska - przeciwieństwem rozwoju gospodarczego, ani z rozwojem gospodarczym naruszającym w sposób istotny i nieodwracalny zasoby środowiska"61. Koncepcja zrównoważonego rozwoju przedstawia nowe mechanizmy zmierzające do rozwoju społeczno-gospodarczego, oparte o zasadę trwałości i samopodtrzymywania się. Wskazuje ona na trzy jego cele:

- sprawiedliwość wewnątrzpokoleniową, polegającą na niwelowaniu dysproporcji w rozwoju i poziomie życia obywateli, likwidacji ubóstwa i zapewnieniu powszechnej opieki zdrowotnej, potrzeb edukacyjnych i kulturalnych,

- sprawiedliwość międzypokoleniową, uwzględniającą konieczność zachowania kapitału naturalnego do dyspozycji przyszłych pokoleń,

- sprawiedliwość wobec istot pozaludzkich ${ }^{62}$, ochrona zwierząt i roślin powinna być celem samym w sobie ${ }^{63}$.

58 A. Skowroński, Zrównoważony rozwój perspektywą dalszego postępu cywilizacyjnego, „Problemy Ekorozwoju", t. 1, nr 2/2006, s. 51.

59 B. Piontek, Koncepcja rozwoju zrównoważonego i trwałego Polski, Wydawnictwo Naukowe PWN, Warszawa 2002, s. 51.

60 J. Machowski, Ochrona środowiska. Prawo i zrównoważony rozwój (Stan prawny na dzień 1 stycznia 2003 r.), Wydawnictwo Akademickie „Żak", Warszawa 2003, s. 100-101.

61 T. Borys, Jak budować program ekorozwoju. Informacje ogólne, Regionalny Ośrodek Ekorozwoju Fundacji Karkonoskiej w Jeleniej Górze, Jelenia Góra 1998, s. 11.

62 D. Pearce, Economics, Equity and Sustainable Development, „Futures", vol. 20, no 6/1988, s. 598-605.

63 D. Kiełczewski, op. cit., s. 29. 
Celem zrównoważonego rozwoju jest wzrost dobrobytu społeczeństwa postrzegany nie tylko jako poprawa jakości i warunków życia, lecz także jako poprawa stanu środowiska naturalnego ${ }^{64}$. Zgodnie z poglądem D.C. Northa „rozwiązywanie problemów współczesnej cywilizacji wiąże się z przechodzeniem od świata, w którym źródłem niepewności jest świat przyrody, do świata, w którym niepewność ta pochodzi ze świata społecznego"65. Rozwój zrównoważony może być rozpatrywany zarówno w wąskim ujęciu (utożsamianym z ekorozwojem), jak i w szerokim (ład zintegrowany). Ekorozwój jest swego rodzaju filozofią wzrostu, która zdaniem T. Borysa „nie może być utożsamiana ani z wąsko rozumianą ochroną środowiska - przeciwieństwem rozwoju gospodarczego, ani z rozwojem gospodarczym naruszającym w sposób istotny i nieodwracalny zasoby środowiska" ${ }^{66}$. Ekorozwój powinien uwzględniać rozwój społeczny, gospodarczy i dbałość o ochronę środowiska ${ }^{67}$. Zasady zrównoważonego rozwoju zostały sformułowane na II konferencji Organizacji Narodów Zjednoczonych „Środowisko i rozwój” (27 zasad). Na plan pierwszy wysuwają się następujące postulaty: zasada stawiania człowieka i jego potrzeb w centrum zainteresowania (harmonizacja rozwoju ludzkości z ochroną środowiska naturalnego), uwzględnianie potrzeb obecnych i przyszłych pokoleń, ochrona środowiska we wszystkich procesach rozwojowych, zmniejszanie ubóstwa na świecie ${ }^{68}$.

Zrównoważony rozwój może być również rozpatrywany w skali regionalnej. Zgodnie z definicją przedstawioną przez D. Kiełczewskiego jest to „takie wykorzystanie regionalnych zasobów, które zapewni społeczności regionu wzrost dobrobytu przy równoczesnym zagwarantowaniu możliwości rozwojowych przyszłym pokoleniom (sprawiedliwość międzypokoleniowa) oraz społecznościom innych regionów (sprawiedliwość wewnątrzpokoleniowa)" ${ }^{69}$. Wydaje się, że wdrażanie zrównoważonego rozwoju na poziomie regionalnym jest szczególnie istotne,

64 T. Pakulska, M. Poniatowska-Jaksch, Rozwój zrównoważony - „szeroka i wąska” interpretacja, stan wiedzy, Wydawnictwo Szkoły Głównej Handlowej Oficyna Wydawnicza, Warszawa 2009, s. 4-7.

65 D.C. North, Understanding Economic Change and Economic Growth (Pojmowanie zmian ekonomicznych i wzrostu gospodarczego), [w:] G.W. Kołodko (red.), Globalizacja, marginalizacja, rozwój, Wydawnictwo Wyższej Szkoły Przedsiębiorczości i Zarządzania im. Leona Koźmińskiego, Warszawa 2003, s. 137.

66 T. Borys, Jak budować program ekorozwoju. Informacje ogólne, Regionalny Ośrodek Ekorozwoju Fundacji Karkonoskiej w Jeleniej Górze, Jelenia Góra 1998, s. 11.

67 B. Podskrobko, Teoretyczne aspekt ekorozwoju, „Ekonomia i Środowisko”, nr 1(10)/1997, s. 9. Pierwsze definicje rozwoju zrównoważonego, zwanego ekorozwojem, sformułowano w Polsce w połowie lat 80;; por. B. Zaufal, M. Białecka, Ekorozwój szansa przetrwania cywilizacji, [w:] Materiały z konferencji Polskiego Klubu Ekologicznego, Wydawnictwo Akademii Górniczo-Hutniczej, Kraków 1986, s. 17.

68 B. Podskrobko, Zarządzanie środowiskiem, Wydawnictwo PWE, Warszawa 1998, s. 124-125.

69 D. Kiełczewski, op. cit., s. 31. 
a przy tym bardziej efektywne, gdyż to właśnie społeczności lokalne są w stanie szybciej reagować na zmieniające się otoczenie.

Władze Unii Europejskiej dostrzegły konieczność zaangażowania mieszkańców w kształtowanie rozwoju gospodarczego i społecznego regionów oraz zachowanie istniejących zasobów przyrody. Należy zauważyć, że zapisy dotyczące ochrony środowiska $\mathrm{w}$ prawie pierwotnym Wspólnot znalazły się stosunkowo późno. Pierwsze wzmianki zawarte zostały w Jednolitym Akcie Europejskim, następnie modyfikowane były przez postanowienia Traktatu $z$ Maastricht i Traktatu Amsterdamskiego. Zapisy Traktatu z Maastricht podkreśliły, że rozwojowi społeczno-gospodarczemu musi towarzyszyć dbałość o ochronę środowiska naturalnego. W Traktacie $z$ Amsterdamu podkreślono, że dbałość o środowisko naturalne jest jednym $\mathrm{z}$ nadrzędnych celów UE, a „w ramach realizowanego rynku wewnętrznego ma być wzmacniana spójność i ochrona środowiska oraz realizowana polityka zapewniająca, aby postępowi $\mathrm{w}$ integracji gospodarczej towarzyszył równoległy postęp w innych dziedzinach"70.

Kolejnym krokiem w realizacji zrównoważonego rozwoju była przyjęta przez Radę Unii Europejskiej w marcu 2000 r. Strategia z Lizbony, której nadrzędnym celem było uczynienie z Unii Europejskiej najbardziej konkurencyjnej gospodarki świata ${ }^{71}$. Początkowo rozwój Wspólnoty miał się opierać na dwóch filarach: ekonomicznym i społecznym. Po szczycie w Goeteborgu dodano trzeci filar: ekologiczny $^{72}$. W czerwcu 2006 r. sporządzono Odnowioną strategię zrównoważonego rozwoju UE, w której sformułowano siedem głównych wyzwań związanych ze zrównoważonym rozwojem: „zmiany klimatu i czysta energia; transport zorganizowany z poszanowaniem zasady zrównoważonego rozwoju, zrównoważona konsumpcja i produkcja; ochrona zasobów naturalnych i gospodarowanie nimi; zdrowie publiczne; integracja społeczna, demografia i migracja oraz ubóstwo na świecie"73.

70 G. Calster, S.J. Berwin, K. Deketelaere, The Intergovernmental Conference and Greening the EU Treaty „„European Environmental Law Review", no 1/1998, s. 14.

71 J. Gierczyńska, Ewolucja wspólnych polityk Unii Europejskiej w kierunku zrównoważonego rozwoju, [w:] D. Kiełczewski, B. Dobrzańska (red.), Ekologiczne problemy zrównoważonego rozwoju, Wydawnictwo Wyższej Szkoły Ekonomicznej w Białymstoku, Białystok 2009, s. 63-64.

72 J.Gierczycka, Ekonomiczne i społeczne problemy realizacji zrównoważonego rozwoju (w aspekcie Strategii Lizbońskiej), [w:] Uwarunkowania i mechanizmy zrównoważonego rozwoju. Materiały VI Międzynarodowej Konferencji Naukowej, Wydawictwo Wyższej Szkoły Ekonomicznej w Białymstoku, Białystok 2007, s. 60.

73 Komisja Europejska, Raport Komisji Europejskiej w sprawie zrównoważonego rozwoju UE, http://www.euractiv.pl/innowacyjnosc-i-kreatywnosc/wywiad/raport-komisji-europejskiej -w-sprawie-zrownowaonego-rozwoju-001161 [dostęp 10.02.2012]. 


\subsection{Teoretyczne koncepcje źródeł zróżnicowania regionalnego}

Zróżnicowanie poziomu rozwoju regionów jest konsekwencją uwarunkowań natury geograficzno-historycznej, jak i przeobrażeń w strukturze przemysłu, w tym zmian w lokalizacji produkcji, liberalizacji wymiany handlowej oraz swobody przepływu czynników produkcji. Kluczowe jest sformułowanie i przedstawienie koncepcji teoretycznej, która w możliwie najlepszy sposób opisywałaby rozwój regionalny. Wydaje się jednak, że złożoność problemów dotyczących rozwoju regionalnego nie daje się zamknąć w ramach jednej, uniwersalnej teorii. W literaturze przedmiotu można znaleźć wiele idei stanowiących odbicie zmian, które zachodzą w światowej gospodarce i powstają na bazie aktualnie przeprowadzanych badań i analiz ${ }^{74}$.

Współczesne teorie rozwoju regionalnego wywodzą się ze szkół ekonomicznych nurtu neoklasycznego i neokeynesowskiego. Pierwsze z nich podkreślają znaczenie wolnego rynku jako mechanizmu zapewniającego równowagę i optymalny rozwój. Teorie neokeynesowskie z kolei akcentują konieczność interwencjonizmu ze strony władz, również w wymiarze regionalnym. Istotne jest, że teorie te powinny się wzajemnie uzupełniać tak, by traktowane jako całość mogły w sposób jak najbardziej obiektywny i całościowy stworzyć uzasadnienie dla zjawisk rozwojowych zachodzących w regionach ${ }^{75}$.

W literaturze przedmiotu istnieje szereg klasyfikacji teorii rozwoju regionalnego. Do dalszej analizy wybrano te, które można odnieść do rozwoju euroregionów. Koncepcje te można podzielić na dwie grupy. Pierwsza odnosi się do rozwoju egzogenicznego (rozwój „od góry”), druga zaś do rozwoju endogenicznego (rozwój „od dołu”)

W myśl koncepcji egzogenicznych potencjał wewnętrzny jest niewystarczający i konieczne są inwestycje zewnętrzne, transfer doświadczeń oraz wsparcie instytucji zewnętrznych. Podstawą koncepcji jest proces „rozlewania się” (spill over) doświadczeń i kapitału z regionów najwyżej rozwiniętych (centralnych) do regionów peryferyjnych. Rozwój obszarów peryferyjnych stanowi tu niejako naturalną konsekwencję rozwoju gospodarki krajowej ${ }^{77}$. Głównym celem obszarów peryferyjnych

74 P. Churski, op. cit., s. 10-12.

75 P. Nowak, Nowy paradygmat rozwoju regionalnego na przykładzie wybranych regionów Europy zachodniej (rozprawa doktorska), Uniwersytet Ekonomiczny w Poznaniu, Poznań 2011, s. 22.

76 T.G. Grosse, Wybrane koncepcje teoretyczne i doświadczenia praktyczne dotyczące rozwoju regionów peryferyjnych, „Studia Regionalne i Lokalne”, nr 1(27)/2007, s. 28-29.

77 H.W. Richardson, Regional policy in a slow-growth economy, [w:] G. Demko (ed.), Regional Development Problems and Policies in Eastern and Western Europe, Croom Helm, London 1984 , s. 258-281. 
jest otwarcie się na zewnętrzny kapitał inwestycyjny, umożliwiający transfer technologii. Regiony tworzą strukturę hierarchiczną, na której szczycie znajdują się wysoko rozwinięte metropolie, a na dole piramidy - obszary peryferyjne ${ }^{78}$. Rozwój regionów peryferyjnych jest fazowy - pierwszy etap polega głównie na dokonywaniu inwestycji infrastrukturalnych i podejmowaniu działań ukierunkowanych na przyciąganie zewnętrznych inwestorów, następnie stopniowo regiony aplikują zewnętrzną technologię i rozwijają usługi wykorzystujące nowoczesne rozwiązania.

Tabela 1.2. Wybrane współczesne koncepcje rozwoju regionalnego

\begin{tabular}{|c|c|c|}
\hline \multirow{4}{*}{ 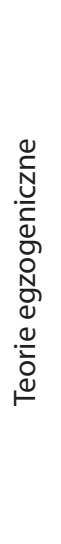 } & $\begin{array}{l}\text { Teoria wzrostu } \\
\text { zrównoważonego }\end{array}$ & $\begin{array}{l}\text { - Zaklęty krąg ubóstwa (niska wydajność pracy - niskie } \\
\text { oszczędności - brak kapitału i niskie dochody gospodarstw } \\
\text { domowych - niska wydajność pracy) } \\
\text { - Wzrost możliwy dzięki inwestorom zewnętrznym } \\
\text { - Inwestycje przedsiębiorstw }\end{array}$ \\
\hline & $\begin{array}{l}\text { Teoria wzrostu } \\
\text { niezrównoważo- } \\
\text { nego }\end{array}$ & $\begin{array}{l}\text { - Każdy kraj ma regiony (lub sektory) określane mianem biegu- } \\
\text { nów wzrostu } \\
\text { - Należy rozwijać te regiony, gdyż konsekwencją ich dalszego } \\
\text { rozwoju jest rozwój regionów o niższym poziomie rozwoju }\end{array}$ \\
\hline & $\begin{array}{l}\text { Teoria interwen- } \\
\text { cjonizmu pań- } \\
\text { stwowego }\end{array}$ & $\begin{array}{l}\text { - Region peryferyjny nie ma atutów rozwojowych (słaba infra- } \\
\text { struktura, duża odległość, brak inwestycji przedsiębiorstw) } \\
\text { - Konieczny interwencjonizm państwowy w zakresie realizacji } \\
\text { i wsparcia inwestycji w regionach peryferyjnych }\end{array}$ \\
\hline & Teoria eksportu & $\begin{array}{l}\text { - Należy wyspecjalizować się w określonej produkcji i ekspor- } \\
\text { tować ją (podaż na rynku wewnętrznym może być za niska) }\end{array}$ \\
\hline \multirow{4}{*}{ 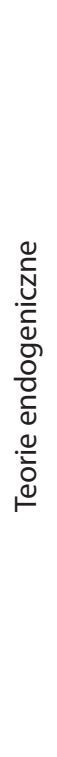 } & $\begin{array}{l}\text { Teoria potrzeb } \\
\text { podstawowych }\end{array}$ & $\begin{array}{l}\text { - Zrównoważony i stabilny rozwój regionu w oparciu o własne } \\
\text { zasoby } \\
\text { - Dbałość o zaspokojenie potrzeb społecznych (oświata, eduka- } \\
\text { cja, kultura itd.) } \\
\text { - Wzrost gospodarczy jako rezultat rozwoju sił wytwórczych }\end{array}$ \\
\hline & $\begin{array}{l}\text { Teoria niezależ- } \\
\text { nego rozwoju } \\
\text { gospodarczego }\end{array}$ & $\begin{array}{l}\text { - Odnosi się do regionów peryferyjnych w krajach wysoko roz- } \\
\text { winiętych } \\
\text { - Swobodny przepływ informacji o technologiach i innowa- } \\
\text { cjach } \\
\text { - Rozbudowa własnego potencjału (region importuje technolo- } \\
\text { gie, które pozwolą zwiększyć mu własne możliwości) }\end{array}$ \\
\hline & $\begin{array}{l}\text { Teoria rozwoju } \\
\text { sieciowego }\end{array}$ & $\begin{array}{l}\text { - Oparta na wzroście kapitału społecznego } \\
\text { - Współpraca wewnątrz regionu } \\
\text { - Pozioma współpraca przedsiębiorstw (te same dobra), piono- } \\
\text { wa współpraca (różne fazy produkcji), diagonalna (specjaliści } \\
\text { ze zbliżonych dziedzin) } \\
\text { - Współpraca przedsiębiorstw z B+R }\end{array}$ \\
\hline & Teoria gron & $\begin{array}{l}\text { - Przedsiębiorstwa działające w pokrewnych sektorach oraz in- } \\
\text { stytucje je otaczające lokalizują swoją działalność w gronach } \\
\text { przemysłowych, tworzą sieć współpracy } \\
\text { - Władze państwowe, regionalne i lokalne powinny prowadzić } \\
\text { politykę regionalną wspierającą rozwój gron przemysłowych }\end{array}$ \\
\hline
\end{tabular}

78 J. Simmie, Innovation and urban regions as national and international nodes for the transfer and sharing of knowledge , "Regional Studies”, vol. 37, no 6-7/2002-2003, s. 607-620. 


\begin{tabular}{|c|c|c|}
\hline \multirow{6}{*}{ 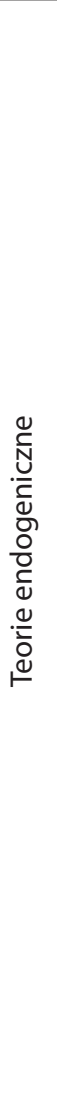 } & $\begin{array}{l}\text { Teoria regionu } \\
\text { uczącego się }\end{array}$ & $\begin{array}{l}\text { - Wiedza i innowacje podstawowym czynnikiem rozwoju } \\
\text { - Środowisko sprzyjające współpracy (przedsiębiorstwa-nauka } \\
\text {-administracja-sektor oganizacji pozarządowych) } \\
\text { - Informacja o innowacjach }\end{array}$ \\
\hline & $\begin{array}{c}\text { Teoria instytucjo- } \\
\text { nalna }\end{array}$ & $\begin{array}{l}\text { - Kształtowanie instytucji formalnych i nieformalnych } \\
\text { - Prawo wspierające przedsiębiorczość, Ochrona prawa własno- } \\
\text { ści } \\
\text { - Kształtowanie kultury ekonomicznej }\end{array}$ \\
\hline & Teorie lokalizacji & $\begin{array}{l}\text { - Wyjaśnia przestrzenne zróżnicowanie rozwoju przez podej- } \\
\text { mowanie działalności gospodarczej w określonych miejscach } \\
\text { w przestrzeni } \\
\text { - Teoria lokalizacji struktur została wyjaśniona na podstawie } \\
\text { tzw. renty położenia, która jest tym wyższa, im miejsce pro- } \\
\text { dukcji znajduje się bliżej miejsca konsumpcji }\end{array}$ \\
\hline & $\begin{array}{l}\text { Teorie polaryzacji: } \\
\text { bieguny wzrostu; } \\
\text { centrum-pery- } \\
\text { ferie }\end{array}$ & $\begin{array}{l}\text { - Skumulowane procesy rozwojowe decydują o przestrzennym } \\
\text { zróżnicowaniu rozwoju } \\
\text { - W teoriach tych zakłada się: zróżnicowanie przestrzeni gospo- } \\
\text { darczej dotyczące determinantów rozwoju, tj.: struktury bran- } \\
\text { żowej oraz konsumpcji i inwestycji; częściową niemobilność } \\
\text { determinantów rozwoju; zależność regionów w procesie roz- } \\
\text { woju; występowanie struktur rynkowych w postaci monopoli } \\
\text { i oligopoli }\end{array}$ \\
\hline & $\begin{array}{l}\text { Nowa geografia } \\
\text { ekonomiczna }\end{array}$ & $\begin{array}{l}\text { - Rozwój regionu jest wypadkową sił odśrodkowych odpowie- } \\
\text { dzialnych za ograniczanie aglomeracji lub ich rozpad oraz sił } \\
\text { dośrodkowych determinujących przyciąganie działalności go- } \\
\text { spodarczej do aglomeracji }\end{array}$ \\
\hline & $\begin{array}{l}\text { Inteligentne spe- } \\
\text { cjalizacje (smart } \\
\text { specialization) }\end{array}$ & $\begin{array}{l}\text { - Koncepcja, według której o rozwoju regionu decyduje jego } \\
\text { potencjał, jego atuty, tzw. specjalizacje regionu } \\
\text { - Koncepcja ta wiąże się z koncepcją klastrową. Podstawą roz- } \\
\text { woju jest zidentyfikowanie własnych zasobów } \\
\text { - Nacisk na innowacje i koncentracja zasobów materialnych } \\
\text { i niematerialnych w kilku obszarach konkurencyjnych w celu } \\
\text { pobudzenia wzrostu gospodarczego }\end{array}$ \\
\hline
\end{tabular}

Źródło: D. Kiełczewski, Różnorodność kulturowa jako czynnik rozwoju Podlasia, [w:] M. Skup, Zrównoważony rozwój - aspekty rozwoju społeczności lokalnych, Fundacja Forum Inicjatyw Rozwojowych, Białystok 2009, s. 29-33; A. Mempel-Śnieżyk, Koncepcje rozwoju regionalnego ze szczególnym uwzględnieniem klastrów i inteligentnych specjalizacji, „Biblioteka Regionalisty”, nr 13/2013, s. 113-114.

Endogeniczne teorie rozwoju koncentrują się na zagadnieniach związanych z wewnętrznym potencjałem regionów oraz możliwościami jego zastosowania $\mathrm{w}$ inteligentnej specjalizacji, wchodzącej w zakres strategii rozwojowej Europa $2020^{79}$. Postęp techniczny jest rezultatem rozwoju nauki, przemysłu, władz rządowych i regionalnych ${ }^{80}$. Zwolennicy koncepcji endogenicznych uważają, że procesy oparte na wewnętrznym potencjale pozwalają na trwały, zrównoważony, autono-

79 M. Greta, Endogeniczność w rozwoju regionów/euroregionów w aspekcie europejskich wyzwań smart specialistaion, „Optimum. Studia Ekonomiczne”, nr 1(67)/2014, s. 46-47.

80 A.H. Jasiński, Innowacje i transfer techniki w procesie transformacji, Wydawnictwo Difin, Warszawa 2006, s. 31. 
miczny i długookresowy rozwój ${ }^{81}$. Takie podejście powoduje, że rozwój regionów peryferyjnych nie jest zależny od regionów centralnych. Uwarunkowany jest zaś przez wewnętrzną akumulację kapitału oraz kapitał ludzki i rzeczowy regionów ${ }^{82}$. Nie zachodzi tu zasada swobodnego „rozlewania” się rozwoju z centrów do peryferii (procesy wolnorynkowe powodują rozwój obszarów metropolitarnych przy jednoczesnym marginalizowaniu regionów peryferyjnych). Procesy globalizacji, wzrost konkurencji oraz mechanizm wolnego rynku powodują różnicowanie regionów pod względem rozwoju, a nie prowadzą do konwergencji między nimi ${ }^{83}$.

Europejska polityka regionalna odnosi się właśnie do tych koncepcji, a jej podstawowym celem jest niwelowanie dysproporcji w poziomie rozwoju regionów europejskich oraz zmniejszanie negatywnych aspektów wprowadzenia wspólnego ryn$\mathrm{ku}^{84}$. Koncepcje rozwoju endogenicznego podkreślają, że regiony posiadają zestaw własnych, unikalnych cech, dlatego konieczne jest budowanie strategii rozwojowych w oparciu o ich indywidualne atrybuty i predyspozycje. Niektórzy badacze przedmiotu podkreślają wręcz, że nie ma jednej uniwersalnej polityki rozwoju regionalnego, a polityki rozwoju są odmienne w zależności od tego, czy odnoszą się do regionów centralnych, czy peryferyjnych ${ }^{85}$. Współczesne koncepcje rozwoju endogenicznego odnoszące się do regionów peryferyjnych akcentują konieczność zewnętrznego wsparcia, otwarcia na zewnętrzne rynki zbytu oraz czerpania z doświadczeń regionów wysoko rozwiniętych (koncepcja izomorfizmu polegająca na „transferze doświadczeń i pomysłów zewnętrznych do miejscowej praktyki politycznej i administracyjnej”) ${ }^{86}$.

Teorie wskazujące na wagę zasobności endogenicznej w szczególnym miejscu stawiają euroregiony, w których ma miejsce koncentracja korzyści wynikających z tradycji handlowych i przemysłowych, zasobów ludzkich, specyficznych cech politycznych i kulturowych oraz położenia geograficznego. Znajomość wewnętrznego potencjału pozwala na podkreślenie mocnych stron euroregionów oraz określenie determinant ich rozwoju ${ }^{87}$. Nowe teorie rozwoju regionalnego, $w$ tym przede wszystkim: nowa geografia ekonomiczna, koncepcje sieci, grona, regionalne systemy innowacji, regiony uczące się stanowią rezultat ponownego zainteresowania kwestiami obszaru i lokalizacji ${ }^{88}$.

81 A. Olechnicka, Regiony peryferyjne w gospodarce informacyjnej, Wydawnictwo Naukowe Scholar, Warszawa 2004, s. 69-92.

82 G. Myrdal, Economic Theory and Underdeveloped Regions, Duckworth, London 1957, s. 23-25.

83 G. Grossman, E. Helpman, Innovation and Growth in the Global Economy, MIT Press, Cambridge 1991, s. 359.

84 T.G. Grosse, op. cit., s. 30.

85 F. Tödtling, M. Trippl, One size fits all? Towards a differentiated regional innovation policy approach, „Research Policy”, vol. 34, no 8/2005, s. 1203-1219.

86 T.G. Grosse, op. cit., s. 32.

87 M. Greta, Endogeniczność w rozwoju..., s. 50-52.

88 R. Florida, Toward the Learning Regions, „Futures”, vol. 27/2005, s. 528. 
Nowa geografia ekonomiczna P. Krugmana podkreśla, że lokalizacja i handel są ze sobą ściśle związane. Bliskość rynków zbytu powoduje, że regiony położone $\mathrm{w}$ ich pobliżu rozwijają się szybciej. Wynika to z faktu, że zwiększają się wówczas przychody skali, a maleją koszty transportu ${ }^{89}$. W ramach teorii powstał, mający istotny wkład w rozwój myśli ekonomicznej, model rdzenia i peryferii, w którym przeciwstawiane są sobie silnie rozwijające się aglomeracje, pozostające w opozycji do obszarów peryferyjnych. Podstawową determinantą rozwoju aglomeracji są przesłanki ${ }^{90}$ : pierwotne - natury geograficznej (rodzaje gruntów, ukształtowanie powierzchni, dostępność do zbiorników wodnych oraz zasoby siły roboczej) oraz wtórne (związane $\mathrm{z}$ lokalizacją przedsiębiorstw głównie $\mathrm{w}$ dobrze rozwiniętych aglomeracjach, w których są odpowiednie zasoby pracowników i dostępność do rynków zbytu). Podstawowym czynnikiem mającym wpływ na rozwój regionalny są koszty handlowe. Przedsiębiorcy koncentrują swoją działalność w regionach, w których koszty są niższe (zazwyczaj regiony centralne). Prowadzi to do wzrostu poziomu rozwoju tzw. rdzeni kosztem obszarów peryferyjnych. Koncentracja przemysłu w ośrodkach aglomeracyjnych zazwyczaj prowadzi do wzrostu kosztów pracy i szeroko rozumianych kosztów urbanizacyjnych, co może stać się jedną z przyczyn decyzji o przeniesieniu działalności gospodarczej do regionów peryferyjnych ${ }^{11}$. Poziom koncentracji przemysłu uwarunkowany jest również przez czynniki, takie jak: koszty transportu, dostępność do produktów i usług, wykwalifikowana kadra pracownicza. Nowa geografia ekonomiczna podkreśla, że koncentracja przemysłu w ośrodkach aglomeracyjnych może prowadzić do wzrostu dysproporcji w poziomie rozwoju regionów.

Ciekawe założenia zawarte są w koncepcji gron Portera, który rekomenduje centralnym władzom państwowym implementacje polityki regionalnej, która wspierałaby rozwój tzw. gron przemysłowych. Grona (klastry) to „geograficzne skupiska wzajemnie powiązanych firm, wyspecjalizowanych dostawców, jednostek świadczących usługi, firm działających w pokrewnych sektorach i związanych z nimi instytucji (na przykład uniwersytetów, jednostek normalizacyjnych i stowarzyszeń branżowych) w poszczególnych dziedzinach, konkurujących między sobą, ale także współpracujących" ${ }^{\prime 2}$. Grona to powiązane wzajemnymi relacjami podmioty gospodarcze, kontrahenci, przedsiębiorcy działający w podobnych branżach i sektorach. Celem władz nie jest tworzenie nowych gron, gdyż to wymagałoby ogromnych inwestycji finansowych, ale wspieranie już istniejących

89 M. Fujita, T. Mori, Frontiers of the New Economic Geography , Discussion Paper", no 27/2005, s. $10-11$.

90 P. Nowak, Nowy paradygmat rozwoju regionalnego na przykładzie wybranych regionów Europy Zachodniej, Uniwersytet Ekonomiczny w Poznaniu, Poznań 2011, s. 31.

91 B. Rokicki, Teoria ekonomiczna a regionalne zróżnicowanie rynku pracy, Uniwersytet Warszawski, Warszawa 2008, s. 5.

92 M.E. Porter, Porter o konkurencji, Wydawnictwo PWE, Warszawa 2001, s. 246. 
centrów. Podmioty gospodarcze działające $\mathrm{w}$ gronach nawiązują współpracę, wykorzystują swoją wiedzę i doświadczenie oraz regionalne zasoby ${ }^{93}$. W ramach klastrów skupione są przedsiębiorstwa, które współpracują, ale też i ze sobą konkurują. Prowadzi to do wzrostu produktywności i innowacyjności oraz spadku kosztów produkcji. Teoria podkreśla, że klastry działają w oparciu o benchmarking polegający na wyszukiwaniu najlepszych światowych praktyk (celem jest równanie do najlepszych ${ }^{94}$. Obecnie w literaturze przedmiotu dominują dwa podejścia do funkcjonowania klastrów. Pierwszy kierunek zwany „szkołą kalifornijską" podkreśla rolę czynników społecznych (charakterystycznych dla danej lokalizacji) i niehandlowych interakcji podmiotów klastra w budowie jego przewagi konkurencyjnej. W ramach tego podejścia analizowane są koncepcje poświęcone sieciom biznesowym, parkom naukowym i inkubatorom przedsiębiorczości oraz lokalnym systemom produkcyjnym. Z kolei „szkoła nordycka” podkreśla naturalną zdolność klastrów do tworzenia innowacji. Klaster stanowi tu pewien złożony system, w którym interakcje pomiędzy podmiotami i instytucjami go tworzącymi pobudzają innowacyjność. W ramach tej szkoły pojawiły się koncepcje środowiska innowacyjnego, regionalnego systemu innowacyjnego i regionu uczącego się̨ ${ }^{95}$.

$\mathrm{U}$ podstaw teorii rozumiejących region jako miejsce tworzenia wiedzy leży przekonanie, że regiony zajmują kluczową pozycję w kreowaniu i rozprzestrzenianiu wiedzy, a poprzez tworzenie odpowiedniej infrastruktury są w stanie zachęcić przedsiębiorców do prowadzenia działalności gospodarczej na ich terenie oraz wprowadzenia innowacji produktowych lub procesowych ${ }^{96}$. Koncepcja inteligentnych specjalizacji wskazuje na konieczność optymalnego wykorzystania wewnętrznego, unikatowego i specyficznego dla każdego regionu potencjału rozwojowego. W koncepcji regionu uczącego się regiony tworzą swoistą platformę wiedzy i kreatywności, a poprzez budowę odpowiedniej infrastruktury umożliwiającej przepływ wiedzy i innowacji przyczyniają się do wzrostu ilości przedsiębiorstw i ułatwienia kooperacji między nimi. Podstawą rozwoju regionów w gospodarce opartej na wiedzy jest umiejętność odpowiedniego wykorzystania i transferu wiedzy. Region uczący się to: ,jednostka terytorialna niezbędna dla rozwoju gospodarki opartej na wiedzy poprzez zagwarantowanie infrastruktury produkcyjnej opartej na powiązanej ze sobą sieci dostawców i nabywców, rynku pracy zapewniającego podaż kreatywnych pracowników wiedzy zdolnych do ustawicznego uczenia się,

93 M. Gorynia, B. Jankowska, Koncepcja klastrów jako sposób regulacji zachowań podmiotów gospodarczych, "Ekonomista”, nr 3/2007, s. 311.

94 E. Wojnicka, P. Rot, P. Tamowicz, T. Brodzicki, Regionalny system innowacyjny w województwie pomorskim, Gdańsk 2001, s. 6.

95 J. Góra, Model dynamiki klastra jako narzędzie badania możliwości adaptacyjno-rozwojowych klastra, http://www.instytut.info/IVkonf/referaty/Gora.pdf, s. 7-9 [dostęp 10.09.2014].

96 S. Juszczyk, M. Jasionek, Żródła i bariery działalności innowacyjnej w przedsiębiorstwach branży spożywczej województwa podlaskiego, ,'Stowarzyszenie Ekonomistów Rolnictwa i Agrobiznesu. Roczniki Naukowe", t. XIII, z. 2/2011, s. 172. 
infrastruktury komunikacyjnej i transportowej umożliwiającej ciągłą wymianę wiedzy i informacji oraz rynku finansowego i polityki przemysłowej dostosowanej do potrzeb organizacji opartej na wiedzy"97. Regiony wykorzystujące know-how są podstawowym elementem rozwoju społecznego, gospodarczego oraz ochrony środowiska w gospodarce opartej na wiedzy. W świetle teorii regionu uczącego się region stanowi centralną jednostkę, gdyż infrastruktura oraz zasoby, które przedsiębiorstwa mogą wykorzystywać dla swojego rozwoju, są na poziomie regionalnym ${ }^{98}$.

Modele regionalnego systemu innowacji oparte są na założeniu, że region innowacyjny jest regionem uczącym się. Przy czym wiedza kreowana w regionach powinna służyć lokalnej społeczności. Regionalny system innowacji oparty jest na sieci wzajemnych powiązań instytucji, których zadaniem jest upowszechnianie w regionach innowacji. Teoria kładzie istotny nacisk na wykształcenie odpowiedniej struktury regionalnej, której bazą jest współpraca pomiędzy instytucjami otoczenia biznesu, nauki czy banków 99 .

W ramach nowej ekonomii instytucjonalnej brakuje wyraźnie wyodrębnionego jednego głównego nurtu metodologicznego, gdyż zawiera ona elementy teorii kosztów transakcji, szkoły austriackiej, praw własności czy programów badawczych ekonomii ewolucyjnej ${ }^{100}$. W ramach nowej ekonomii instytucjonalnej poruszane są dwa kluczowe zagadnienia związane z instytucjami oraz kosztami transakcyjnymi. Koszty transakcyjne rozumiane są tu jako koszty funkcjonowania systemu ekonomicznego. U podstaw teorii leży przekonanie teoretyków, że zjawiska społeczne, gospodarcze i polityczne muszą być analizowane z uwzględnieniem ich otoczenia instytucjonalnego ${ }^{101}$. Efektywność systemu uzależniona jest od „zdolności systemu instytucjonalnego do ustawicznego dostosowywania się do zmian technologicznych i demograficznych oraz szoków pojawiających się w systemie społecznym"102. W ramach nurtu instytucjonalnego podejmowane są próby ocenienia wpływu roli instytucji na rozwój regionalny, roli innowacji w rozwoju regionalnym (próba odpowiedzi na pytanie, dlaczego innowacje technologiczne szybciej rozwijają się w jednym regionie, a wolniej w innych), uwarunkowań społeczno-kulturowych

97 M. Godowska, Region uczący się - uwarunkowania i determinanty rozwoju na przykładzie województwa małopolskiego, „Rola Przedsiębiorczości w Edukacji”, nr 8, http://p-e.up.krakow. $\mathrm{pl} /$ article/viewFile/126/65, s. 279 [dostęp 10.02.2012].

98 R. Florida, Toward the learning region, „Futures”, vol. 27, no 5/1995.

99 M. Kochmańska, Regionalne systemy innowacji, http://www.sbc.org.pl, s. 29 [dostęp 10.02.2012].

100 B. Fiedor, Nowa Ekonomia Instytucjonalna jako podstawa teoretycznej refleksji nad procesem transformacji od gospodarki centralnie sterowanej do rynkowej, Otwarty Uniwersytet Ekonomiczny Wiedzainfo.pl, http://www.wiedzainfo.pl, s. 1 [dostęp 10.10.2012].

101 M. Rosińska, Analiza ekonomiczna przedsiębiorstwa w oparciu o teorie instytucjonalne - koncepcja "instytucjonalizmu organizacyjnego przedsiębiorstw”, "Acta Universitatis Lodziensis. Folia Oeconomica", 221/2008, s. 257-275.

102 J. Godłów-Legiędź, Transformacja ustrojowa z perspektywy nowej ekonomii instytucjonalnej, „Ekonomista", nr 2/2005, s. 176. 
(otoczenie społeczne ma wpływ na zwyczaje w kwestii zakładania i prowadzenia działalności gospodarczej, a tym samym przyczynia się do rozwoju regionu) oraz problematyki zarządzania i kierowania rozwojem regionalnym ${ }^{103}$. Interesującą koncepcją rozwoju regionalnego powstałą na gruncie nowej ekonomii instytucjonalnej jest podejście Michaela Storpera, który uważa, że na rozwój wpływ mają innowacje technologiczne, kooperacja $\mathrm{w}$ ramach systemu produkcji oraz koncentracja producentów w poszczególnych regionach ${ }^{104}$.

Podsumowując rozważania dotyczące wybranych współczesnych teorii rozwoju regionalnego, można uznać, że o pozycji regionów decyduje szereg czynników zarówno endogenicznych, jak i egzogenicznych. Obowiązujący obecnie paradygmat rozwoju regionalnego podkreśla, że warunkiem rozwoju gospodarczego w regionach jest wiedza oraz umiejętność jej praktycznego wykorzystania. Należy zaznaczyć, że nowy model rozwoju eksponuje znaczenie wewnętrznego potencjału regionów ${ }^{105}$. Dobre rozpoznanie możliwości endogenicznych pozwala na właściwe, skoordynowane i celowe wskazanie działan priorytetowych, które powinny być $\mathrm{w}$ pierwszej kolejności dofinansowane $\mathrm{z}$ funduszy unijnych. Kluczowe jest uwzględnienie swoistej kombinacji, zawierającej cechy i zasoby naturalne danego terytorium oraz jego potencjał w kształtowaniu wiedzy i innowacji ${ }^{106}$. Zastosowanie tu mogą mieć wnioski wypływające z teorii, takich jak: koncepcja gron Portera, regionów „uczących się" czy regionalnych systemów innowacji ${ }^{107}$.

\subsection{Regiony w Unii Europejskiej}

Unia Europejska stanowi swego rodzaju rezultat regionalizacji zachodzącej w dzisiejszym zglobalizowanym świecie, stanowiąc szczególny supranarodowy region $^{108}$. Pozycja regionów w Unii Europejskiej jest coraz silniejsza, spowodowane jest to zwiększeniem świadomości regionalnej, zmianą reguł i zależności ekonomicznych charakteryzujących ogół stosunków międzynarodowych. Świadomość regionalna powoduje konieczność efektywnego zarządzania swoim obszarem. Po-

103 R. Martin, Institutional Approaches in Economic Geography, [w:] E. Sheperd, T.J. Barnes, A Companion in Economic Geography, Blackwell, Oxford 2000, s. 77-94.

104 M. Stroper, The Regional Word. Territorial Development in a Global Economy, The Guilford Press, New York 1997, s. 5-10.

105 A. Amin, An Institutionalist Perspective on Regional Economic Development, "International Journal of Urban and Regional Research", vol. 23, no 2/1999.

106 M. Greta, Endogeniczność w rozwoju ..., s. 51.

107 R. Florida, Toward the Learning Regions, „Futures", vol. 27, no 5/2005, s. 528.

108 M. Cichocki, Regionalizacja versus integracja. Teorie rozwoju regionalnego a polityka bezpieczeństwa , „Nowa Europa. Przegląd Natoliński”, nr 1(11)/2011, s. 4. 
jęcie „Europy regionów” nabiera nowego znaczenia nie tylko w kontekście mikroekonomicznym, dotyczącym rozwoju i poprawy życia społeczności lokalnych, lecz także w aspekcie makroekonomicznym ${ }^{109}$.

\subsubsection{Procesy kształtowania się regionów w Unii Europejskiej}

Unia Europejska nie jest jednolitym organizmem - występują różnice w poziomie rozwoju gospodarczego, społecznego, kulturowego, politycznego. Od samego początku funkcjonowania Wspólnoty jej regiony charakteryzowały się zróżnicowaniem w poziomie rozwoju gospodarczego ${ }^{110}$. Nierówności na terenie Unii Europejskiej pojawiły się już w latach osiemdziesiątych, kiedy do ugrupowania przystąpiły Grecja, Hiszpania i Portugalia, kraje o niższym poziomie rozwoju i o zdecydowanie biedniejszych regionach, a stały się jeszcze bardziej widoczne w pierwszej dekadzie XXI w., kiedy to do ugrupowania dołączyły zdecydowanie słabiej rozwinięte kraje Europy Środkowo-Wschodniej. Znaczne zróżnicowanie rozwoju regionów oraz postępująca globalizacja spowodowały wzrost zainteresowania problematyką rozwoju regionalnego ${ }^{111}$. Pozycja regionów w Unii Europejskiej jest dodatkowo wzmacniana poprzez postępujące procesy integracji gospodarek i wdrażanie zasady subsydiarności ${ }^{112}$.

U źródeł proregionalnego nurtu integracji europejskiej leży przekonanie o tym, że regiony działają efektywniej niż całe państwa ${ }^{113}$. Regiony w Unii Europejskiej, jak pisze W. Jastrzębska, „powstają w wyniku procesów endogenicznych, czyli w oparciu o własny potencjał regionalny, na który składają się: regionalna przestrzeń, międzynarodowy system społeczny (w tym kapitał społeczny), system instytucjonalny oraz własny dorobek kulturowy" 114 . W ujęciu tym podkreślona jest odrębność regionalna, która odróżnia dany region od regionów z nim sąsiadujących. Stanowi ona główny element tworzenia i formowania się nowych regionów,

109 Ibidem, s. 3.

110 K. Czubocha, Finansowanie polityki regionalnej Unii Europejskiej a wyzwania XXI wieku, „eFinanse. Kwartalnik Finansowy", nr 3/2006 [dostęp 15.05.2015].

111 A. Olechnicka, Regiony peryferyjne w gospodarce informacyjnej, Wydawnictwo Naukowe Scholar, Warszawa 2004, s. 43.

112 W. Jastrzębska, op. cit., s. 96-97.

113 J. Strzelec, Doświadczenia i wyzwania rozwoju regionalnego w latach 1999-2013 na przykładzie województwa świętokrzyskiego, Wydawnictwo Uniwersytetu Humanistyczno-Przyrodniczego im. Jana Kochanowskiego, Kielce 2010, s. 10-11; M. Proniewski, Uwarunkowania i kierunki polityki rozwoju regionalnego Unii Europejskiej, „Przestrzeń \& Regiony. Rocznik Wydziału Gospodarki Przestrzennej Wyższej Szkoły Finansów i Zarządzania", nr 2/2013, s. 7.

114 W. Jastrzębska, op. cit., s. 97. 
które kształtują się poprzez procesy endogeniczne i „poprzez formy organizacji, które ułatwiają komunikację i przenikanie wartości”"115.

Znamienne jest uzależnienie kształtowania i rozwoju regionów w Unii Europejskiej od struktury terytorialnej poszczególnych państw. Opracowania poświęcone tematyce regionalnej zawierają wiele różnych typologii państw w zależności od występującej w nich struktury terytorialnej. Komitet Regionów, dokonując klasyfikacji tych struktur, położył szczególny nacisk na rolę regionów w rozwoju państw. Różne poziomy struktur państwa doprowadziły do wykształcenia się kilku modeli regionów w Unii Europejskiej:

- Model 1 - regiony mające legitymację do ustanawiania prawa pierwotnego zapisaną w konstytucji (np. landy niemieckie, specjalne regiony włoskie i belgijskie),

- Model 2 - regiony mające możliwość ustanawiania przepisów prawa pierwotnego bez gwarancji w ustawie zasadniczej (Irlandia Północna, Szkocja, Hiszpania),

- Model 3 - regiony mające uprawnienia do uchwalania prawa wtórnego zgodnie z konstytucją (Czechy, regiony włoskie),

- Model 4 - regiony mające możliwość uchwalania prawa wtórnego bez zagwarantowania im tej możliwości w konstytucji (Polska, Walia),

- Model 5 - regiony nie są organami upoważnionymi do stanowienia prawa, mogą natomiast podejmować decyzje mające wpływ na funkcjonowanie i rozwój regionów (Francja, Dania, Szwecja),

- Model 6 - regiony niemające możliwości stanowienia prawa, mogą podejmować decyzje, posiadają władze pochodzące $\mathrm{z}$ wyborów (Finlandia) ${ }^{116}$.

Modele funkcjonowania regionów zaprezentowane powyżej wyraźnie wskazują na miejsce i rolę regionów w wewnętrznym systemie funkcjonowania państw członkowskich Unii Europejskiej, natomiast statystyka NUTS określa, w jaki sposób należy rozdysponować pomoc w ramach unijnej polityki regionalnej.

\subsubsection{Przestrzenne zróżnicowanie poziomu rozwoju regionalnego w Unii Europejskiej}

Zróżnicowanie poziomu rozwoju społeczno-gospodarczego i terytorialnego poszczególnych regionów europejskich jest konsekwencją uwarunkowań natury geograficzno-historycznej oraz przeobrażeń w strukturze przemysłu, u podstaw

115 F. Danielewski, Regionalizm: pojęcie, ewolucja, [w:] R. Fedan (red.), Przedsiębiorstwo i region. Przedsiębiorstwo i region w procesie transformacji, Uniwersytet Rzeszowski, Rzeszów 2006, s. 16.

116 I. Pietrzyk, Polityka regionalna Unii Europejskiej i regiony w państwach członkowskich, Wydawnictwo Naukowe PWN, Warszawa 2004, s. 299. 
których leżą zmiany w lokalizacji produkcji i liberalizacja wymiany handlowej oraz swoboda przepływu czynników produkcji ${ }^{117}$. Asymetria w rozwoju poszczególnych regionów jest widoczna i stanowi podstawę dla prowadzonej unijnej polityki regionalnej.

Najbogatszymi regionami, charakteryzującymi się wysokim poziomem rozwoju gospodarczego i społecznego są głównie największe aglomeracje miejskie (Londyn, Paryż, Bonn, Amsterdam, Rzym i Mediolan). Wyraźnie zaznaczona sieć rozwoju rozciąga się przez Francję, Niemcy, Austrię. Terytoria obejmujące obszary Europy Środkowo-Wschodniej można uznać za obszary potencjalnie silnego wzrostu i rozwoju ${ }^{118}$.

U źródeł różnego tempa rozwoju regionalnego w Unii Europejskiej leży peryferyjne położenie regionów słabiej rozwiniętych względem tzw. biegunów wzrostu $^{119}$. Do zwiększania dysproporcji w rozwoju przyczynia się również pogłębianie procesów integracji i pojawienie się efektu przestrzennej koncentracji $^{120}$. Rozwój regionalny w Unii Europejskiej odbywa się na trzech płaszczyznach: międzynarodowej (horyzontalnej) pomiędzy krajami, krajowej (interregionalnej) - dotyczącej problemów regionalnych krajów, lokalnej (intraregionalnej) w skali potrzeb rozwoju regionów wewnątrzkrajowych, posiadających struktury administracyjno-samorządowe ${ }^{121}$.

\subsubsection{Współczesne uwarunkowania rozwoju regionalnego}

Regiony w Unii Europejskiej zaczynają odgrywać rolę pierwszoplanowych aktorów, a debaty dotyczące przyszłości Wspólnoty koncentrują się na zwiększeniu ich autonomii i uprawnień. Decentralizacja staje się głównym elementem polityki ugrupowania, a klimat międzynarodowych stosunków gospodarczych i politycznych sprzyja wzrostowi roli regionów. Restrukturyzacja i przemiany w strukturze przemysłu, efekty realizacji wspólnego rynku, globalizacja ekonomii niewątpliwie przyczyniają się do wzrostu znaczenia regionów, które odgrywają podstawową rolę

117 J. Żebrowska, Angielsko-polski słownik dla beneficjentów programu PHARE spójność gospodarcza i społeczna, Polska Agencja Rozwoju Regionalnego, Warszawa 2001.

118 M. Zając, Zadania polityki regionalnej Unii Europejskiej wobec wzrostu zróżnicowań regionalnych zwiq̨zanych z ostatnim rozszerzeniem, "Zeszyty Naukowe Akademii Ekonomicznej w Krakowie", nr 701/2006, s. 95; T. Latocha, Bezpośrednie inwestycje zagraniczne w Unii Europejskiej w świetle teorii rozwoju regionalnego i teorii lokalizacji, Łódź 2005, s. 46.

119 W. Misiak, J.L. Siemiński, Koncepcje rozwoju regionalnego Polski w świetle doświadczeń inte-

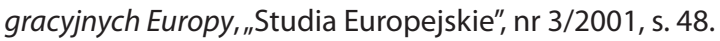

120 J.Witkowska, Bezpośrednie inwestycje zagraniczne w Europie Środkowowschodniej na gruncie teorii bezpośrednich inwestycji zagranicznych, Wydawnictwo Uniwersyetu Łódzkiego, Łódź 1996, s. 180.

121 W. Misiak, J.L. Siemiński, op. cit., s. 35-37. 
w polityce przemysłowej i zatrudnienia. $Z$ tego punktu widzenia konieczne jest efektywne zarządzanie własnym potencjałem, zasobami naturalnymi i ludzkimi ${ }^{122}$.

Na przestrzeni ostatnich lat aktywność regionów w kwestii nawiązywania stosunków społeczno-gospodarczych z partnerami w całej Europie jest coraz bardziej widoczna. Integracja regionalna nabiera rozpędu i coraz większego znaczenia. Reprezentację regionów w UE stanowią: Komitet Regionów, Kongres Władz Lokalnych i Regionalnych, Zgromadzenie Regionów) ${ }^{123}$. Rola regionów w rozwoju gospodarczym, nawiązywaniu stosunków społecznych i politycznych, a także postępowaniu procesów integracyjnych jest bezsprzeczna. Coraz częściej podkreśla się oddolne, czyli regionalne i lokalne walory procesów integracyjnych. Integracja regionalna pozwala, jak twierdzi R. Suchocka, „być obywatelem Europy nie za pośrednictwem państwa członkowskiego, ale poprzez bardziej bliską mieszkańcom reprezentację regionalną"124. Bazując na doświadczeniach federalnych lub zregionalizowanych państw członkowskich, można stwierdzić, że regiony, będąc bliżej obywateli, efektywniej rozwiązują problemy. Regionalizacja umożliwia zrównoważony rozwój przestrzenno-gospodarczy, a także zapewnia bezpośrednie uczestnictwo społeczności lokalnych w podejmowaniu decyzji ważnych z punktu widzenia rozwoju regionalnego ${ }^{125}$.

Model funkcjonowania Unii Europejskiej w myśl koncepcji „Europy ojczyzn” przeżywa bardzo wyraźny kryzys. Niewątpliwie na taki stan rzeczy wpływ miały światowy kryzys gospodarczy i zawirowania w strefie euro spowodowane zwiększającym się długiem publicznym wielu krajów, które wprowadziły wspólną walutę. Odpowiedzią na taki stan rzeczy może być rozwój koncepcji „Europy regionów” ${ }^{26}$. Termin „Europa regionów”, jak pisze S. Parzymies, oznacza „wychodzącą poza granice poszczególnych europejskich państw narodowych bezpośrednią współpracę między wyodrębnionymi według kryteriów właściwych dla każdego $\mathrm{z}$ tych państw jednostkami terytorialnymi, formalnie lub nieformalnie nazywanymi regionami” ${ }^{127}$. Z kolei W. Weidenfeld i W. Wessels podkreślają, że „Europa regionów” jest „włączeniem »trzeciego szczebla« - regionów - do europejskiego procesu integracji, a także alternatywny wzorzec, uwzględniający, przede wszystkim kulturową i polityczną różnorodność, samodzielność i zdolność do

122 M. Dammeyer, Rozwój regionów w Europie, „Studia Europejskie. Komitet Regionów Unii Europejskiej", 2/1999, s. 14-16.

123 M. Balak-Hryńkiewicz, Europa regionów a zasada subsydiarności w Unii Europejskiej, Świętokrzyskie Centrum Edukacji na Odległość, Kielce 2007, s. 7-8.

124 R. Suchocka, Regiony w procesie europejskiej integracji, [w:] P. Buczkowski, K. Bondyra, P. Śliwa (red.), Jaka Europa? Regionalizacja a integracja, Wydawnictwo Wyższej Szkoły Bankowej, Poznań 1998, s. 100-102.

125 M. Dammeyer, op. cit., s. 16.

126 M. Balak-Hryńkiewicz, op.cit, s. 8-9.

127 S. Parzymies, Europa regionów, ,Sprawy Międzynarodowe”, nr 3/1994, s. 29. 
działania regionów oraz przybliżenia procesu decyzyjnego do obywateli”128. Koncepcja ta ma wielu zwolenników, ale ma też oponentów, którzy uważają, że polityka spójności powinna być kreowana na poziomie państwowym ${ }^{129}$.

Bezsprzecznie coraz wyraźniejsze jest zaangażowanie regionów w podejmowanie decyzji dotyczących kształtu i przyszłości Unii Europejskiej. Współpraca pomiędzy poszczególnymi regionami również nabiera większego znaczenia, a regiony stają się centralnym punktem dyskusji nad kształtem polityki spójności. Zwiększona aktywność regionów jest zauważalna w trzech aspektach:

- formułowaniu nowych przepisów legislacyjnych,

- rozwijaniu współpracy transgranicznej, zarówno tej niezinstytucjonalizowanej, jak i w formie euroregionów,

- kształtowaniu sfery gospodarczej i finansowania rozwoju regionalnego ${ }^{130}$.

Regiony odgrywają zasadniczą rolę $\mathrm{w}$ realizacji unijnej strategii na rzecz zatrudnienia i wzrostu, której zadaniem jest wyjście Europy ze światowego kryzysu gospodarczego. Główna rola przypisana regionom dotyczy zapewnienia trwałego, a zarazem inteligentnego wzrostu gospodarczego, który sprzyja aktywizacji społecznej. Konieczne dla rozwoju regionów jest bardziej efektywne wykorzystanie środków finansowych pochodzących z funduszy unijnych, jak i poszerzenie współpracy $\mathrm{z}$ regionami sąsiadującymi $\mathrm{w}$ celu rozwiązywania problemów społeczno-gospodarczych.

\subsection{Uwagi końcowe}

Region rozumiany jest jako wydzielony obszar posiadający pewne charakterystyczne cechy pozwalające na jego delimitację. Rozwój regionów jest jednym z podstawowych punktów realizacji unijnej polityki na rzecz trwałego i zrównoważonego rozwoju. Wdrażanie koncepcji zrównoważonego i trwałego rozwoju na poziomie regionalnym wydaje się naturalną konsekwencją procesów zachodzących w Unii Europejskiej oraz zmian w podejściu do koncepcji rozwoju regionalnego. Obecnie dominuje pogląd, że rozwój regionalny jest determinowany przez konieczność mobilizowania wewnętrznego potencjału regionu, zaś rolą władz jest inicjowanie prac i czynności ukierunkowanych na wsparcie oddolnych inicjatyw, podnoszących konkurencyjność i poziom rozwoju społeczno-gospodarczego. Rozwój regionalny uwarunkowany jest przez szereg czynników, do których można

128 W. Weidenfeld, W. Wessels, Europa od A do Z, Wydawnictwo „Wokół Nas”, Gliwice 1999, s. 64.

129 T. Kupiec, Rola regionów w Europie w kontekście polityki spójności UE, Katowice 2009, s. 10-11.

130 A. Palej, Wzrost znaczenia regionów i ich roli w Unii Europejskiej na przykładzie najnowszych propozycji i postulatów w wymiarze politycznym i ekonomicznym, Kraków-Przegorzały 2009. 
zaliczyć: liczbę instytucji otoczenia biznesu, normy społeczno-kulturowe, dostępność do ośrodków naukowych, klimat gospodarczy, innowacje, potencjał ludzki, interwencjonizm ze strony władz publicznych. W myśl zasady subsydiarności władze regionalne mogą efektywniej realizować zadania zapewniające trwały i zrównoważony rozwój lokalnych obszarów. Ma to szczególnie istotne znaczenie z punktu widzenia spójności społecznej, gospodarczej i ekologicznej w Unii Europejskiej. Region stanowi obecnie ważne miejsce w unijnej polityce na rzecz wzrostu, której podstawowym celem jest niwelowanie dysproporcji w poziomie rozwoju społeczno-gospodarczego i poprawa poziomu życia obywateli Unii Europejskiej. 


\section{Rozdział 2}

\section{Instrumenty finansowe unijnej polityki regionalnej dla rozwoju regionów}

\subsection{Uwagi wstępne}

Instrumenty finansowe Unii Europejskiej ukierunkowane są na osiągnięcie równomiernego i trwałego rozwoju regionów. Ten rozdział stanowi próbę odpowiedzi na następujące pytanie badawcze: Czy ewolucja instrumentów finansowych polityki regionalnej wpływa na efektywność ich wykorzystania? Ponad trzydziestoletnie doświadczenie w kształtowaniu unijnej polityki regionalnej wskazuje, że stanowi ona ważny element rozwoju regionów we Wspólnocie. U podstaw polityki regionalnej leży przekonanie o niemożności samoistnego niwelowania się dysproporcji i konieczności pomocy ze strony Unii Europejskiej we wdrażaniu rozwiązań prawnych i ekonomicznych. Na przestrzeni ostatnich lat polityka regionalna UE ewoluowała w kierunku zwiększenia efektywności i skuteczności, co bezpośrednio związane jest ze zwiększeniem racjonalności i maksymalnym wykorzystaniem środków finansowych $\mathrm{z}$ funduszy unijnych. Polityka regionalna w ostatnim okresie zyskała na znaczeniu, jednocześnie wyraźnie widać, że wprowadzono nowe, prostsze procedury oraz położono nacisk na nowe podejście do planowania rozwoju regionalnego. W rozdziale omówiono zagadnienia teoretyczne związane z rozwojem i ewolucją unijnej polityki regionalnej.

\subsection{Polityka regionalna Unii Europejskiej - rys historyczny, uwarunkowania, implikacje}

Unia Europejska należy do najbogatszych regionów świata, choć na jej obszarze występują znaczne różnice w poziomie rozwoju społeczno-gospodarczego, warunków i jakości życia obywateli. Instrumentem służącym niwelowaniu asymetrii 
w rozwoju poszczególnych obszarów Unii Europejskiej jest polityka regionalna ${ }^{1}$, która jest „działaniem mającym na celu, przy pomocy zespołu instrumentów prawnych i finansowych, usunięcie dysproporcji w rozwoju gospodarczym i społecznym regionów w UE oraz zapewnienie zrównoważonego wzrostu wszystkich jej obszarów z zachowaniem jej wewnętrznej spójności ekonomicznej i społecznej”2. Oznacza również „bezpośrednie i pośrednie oddziaływanie na przestrzenną strukturę gospodarki poprzez wspomaganie rozwoju wybranych regionów”3. Jak podkreśla art. 174 Traktatu $z$ Maastricht, działania Unii Europejskiej w sposób szczególny koncentrują się na wsparciu „obszarów wiejskich, obszarów podlegających przemianom przemysłowym i regionom, które cierpią na skutek poważnych i trwałych niekorzystnych warunków przyrodniczych lub demograficznych"4.

\subsubsection{Geneza i rozwój polityki regionalnej - wczoraj i dziś}

Pejoratywne konsekwencje występowania dysproporcji w rozwoju regionów w Europie Zachodniej zostały zauważone już w latach trzydziestych XX w. w okresie „Wielkiego Kryzysu”. Dostrzeżono wówczas, że zróżnicowanie w rozwoju poszczególnych obszarów przyczynia się do pogłębiania niepokojów społecznych i politycznych. Po II wojnie światowej polityka regionalna na dobre wkroczyła na arenę stosunków międzynarodowych. W początkowym okresie ograniczała się do redystrybucji środków finansowych na rzecz regionów uboższych, następnie ewoluowała w kierunku stopniowej regionalizacji państw, aż wreszcie stała się podstawową polityką realizowaną przez Unię Europejską ${ }^{5}$.

W podpisanym w 1958 r. Traktacie Rzymskim ujęto zapis, że „państwa członkowskie pragną wzmocnienia jedności swoich gospodarek i zabezpieczenia ich harmonijnego rozwoju poprzez redukowanie zróżnicowań istniejących między regionami oraz łagodzenie zacofania regionów mniej uprzywilejowanych”. Ogólnikowy zapis zawarty $\mathrm{w}$ preambule nie przełożył się na praktyczne działania w zakresie rozwoju poszczególnych regionów. Zawierał jedynie apel do państw

$1 \quad$ M. Zając, Zadania polityki regionalnej Unii Europejskiej wobec wzrostu zróżnicowań regionalnych zwiqzanych z ostatnim rozszerzeniem, „Zeszyty Naukowe Akademii Ekonomicznej w Krakowie", nr 701/2006, s. 95; B. Winiarski, Polityka gospodarcza, Wydawnictwo Naukowe PWN, Warszawa 2006, s. 278-286.

2 M. Rudnicki, Polityka regionalna Unii Europejskiej, Wydawnictwo Wyższej Szkoły Bankowej, Poznań 2000, s. 30.

3 M. Ciepielewska, B. Mucha-Leszko, Integracja Europejska. Droga do unii ekonomicznej i monetarnej, Wydawnictwo Uniwersytetu Marii Curie-Skłodowskiej, Lublin 1994, s. 83.

4 Traktat o Unii Europejskiej (Traktat z Maastricht), Dz.U.C 191 z 29.07.1992 r.

5 S. Łodziński, Cele i zasady polityki regionalnej w Unii Europejskiej, „Kancelaria Sejmu Biuro Studiów i Ekspertyz", nr 483/1997, http://biurose.sejm.gov.pl/teksty_pdf_97/i-483.pdf, s. 1 [dostęp 12.07.2015]. 
tworzących Wspólnotę o prowadzenie polityki wewnętrznej ukierunkowanej na niwelowanie różnic w rozwoju poszczególnych regionów. Na mocy postanowień Traktatu Rzymskiego powołano do życia Europejski Bank Inwestycyjny, którego zadaniem zgodnie $\mathrm{z}$ art. 267 jest „przyczynianie się, dzięki środkom pochodzącym z rynku kapitałowego i źródeł własnych, do zrównoważonego i stabilnego rozwoju rynku wewnętrznego Wspólnoty”. Europejski Bank Inwestycyjny jest instytucją non profit, a jego zadaniem jest udzielanie pożyczek i kredytów na realizację projektów przyczyniających się do rozwoju regionów zacofanych, poprzez wspieranie inwestycji w infrastrukturę, projekty badawcze i innowacyjne, poprawę stanu środowiska naturalnego i energetykę $e^{6}$. Traktat Rzymski powołał do życia Europejski Fundusz Społeczny, którego głównym celem było zwiększanie stanu zatrudnienia. Jest to najstarszy fundusz strukturalny, a nadzór nad jego pracami sprawuje powołana w 1968 r. Dyrekcja Generalna ds. Polityki Regionalnej, która również nadzoruje funkcjonowanie Europejskiego Funduszu Rozwoju Regionalnego, Funduszu Kohezji (Spójności) i Przedakcesyjnego Instrumentu Strukturalnego (ISPA).

Tabela 2.1. Etapy polityki regionalnej UE

\begin{tabular}{|l|l|}
\hline Etapy funkcjonowania polityki regionalnej & \multicolumn{1}{|c|}{ Ewolucja polityki regionalnej } \\
\hline I etap (pasywna polityka regionalna) & $\begin{array}{l}\text { Powołanie Europejskiego Banku Inwestycyjnego } \\
\text { (1958) i Dyrekcji Generalnej ds. Polityki Regional- } \\
\text { nej (1968), powstanie Europejskiego Funduszu } \\
\text { Rozwoju Regionalnego (1975) }\end{array}$ \\
\hline II etap (aktywizacja polityki regionalnej) & $\begin{array}{l}\text { Reformy z 1984, podpisanie JAE, reforma fundu- } \\
\text { szy strukturalnych (1988) }\end{array}$ \\
\hline III etap (nowy model polityki regionalnej) & $\begin{array}{l}\text { Traktat z Maastricht (1992), utworzenie Funduszu } \\
\text { Spójności, powołanie Komitetu Regionów, Agen- } \\
\text { da 2000 }\end{array}$ \\
\hline
\end{tabular}

Źródło: opracowanie własne na podstawie: K. Gawlikowska-Hueckel, A. Zielińska-Głębocka, Integracja europejska. Od jednolitego rynku do unii walutowej, Wydawnictwo C.H. Beck, Warszawa 2004, s. 197-198.

Do końca lat 60. XX w. polityka regionalna realizowana była w ramach budżetów państw członkowskich poprzez dotacje, subwencje, ulgi podatkowe i wydatki na inwestycje realizowane na rzecz regionów o niższym poziomie rozwoju. W latach 80. XX w. zakwestionowano taki sposób realizacji polityki, gdyż nie przynosiła ona pożądanych rezultatów ${ }^{7}$. Konieczne stało się przeorientowanie celów polity-

$6 \quad$ K. Michałowska-Gorywoda, Instytucje finansowe unii europejskiej, http://www.nbportal.pl/ library/pub_auto_B_0002/KAT_B2008.PDF [dostęp 05.10.2009].

7 I. Pietrzyk, Polityka regionalna Unii Europejskiej i regiony w państwach członkowskich, Wydawnictwo Naukowe PWN, Warszawa 2001, s. 17. 
ki i zmiana roli państwa, które stało się jednym z podmiotów realizujących zadania regionalne, obok samorządów terytorialnych i podmiotów gospodarczych ${ }^{8}$.

W 1972 r. Europejski Fundusz Społeczny oraz Europejski Fundusz Orientacji i Gwarancji Rolnej otrzymały status funduszy regionalnych. Zdecydowano się również na utworzenie Europejskiego Funduszu Rozwoju Regionalnego (w 1975 r.). Jego powstanie przez wielu uważane jest za początek właściwej polityki regionalnej w Unii Europejskiej. Środki zgromadzone w Funduszu miały refundować wydatki państw członkowskich ponoszone na realizację zadań polityki regionalnej zgodnie z priorytetowymi celami rozwoju regionalnego krajów. Ustalono tzw. kwoty krajowe, a projekty realizowano w oparciu o zasadę współfinansowania (20-30\% całości kosztów) $)^{9}$ W 1979 r. ustalono, że 5\% środków z funduszu przeznaczane będzie dla Komisji Europejskiej na realizację wybranych przez nią celów polityki regionalnej. Istotną zmianą $\mathrm{w}$ funkcjonowaniu funduszu było wprowadzenie w $1985 \mathrm{r}$. tzw. widełek interwencji (zastąpiły one kwoty krajowe). Ustalono również, że minimalny udział interwencji będzie wynosił 88,5\% (11,5\% do dyspozycji Komisji Europejskiej). Wprowadzono również zasadę programowania rozwoju regionalnego, odstąpiono od finansowania pojedynczych projektów na rzecz dużych programów mających kluczowe znaczenie dla Wspólnoty.

Dopiero w drugiej połowie lat 80 . zdecydowano się na rozszerzenie dotychczasowych działań i ich ukierunkowanie na pomoc regionom o niższym tempie rozwoju. W Jednolitym Akcie Europejskim (1987 r.) sprecyzowano cel i zakres polityki regionalnej Wspólnot. W myśl art. 130a JAE: „W celu promowania ogólnego harmonijnego rozwoju Wspólnota powinna rozwinąć akcje prowadzące do wzmocnienia swojej ekonomicznej i społecznej spójności. W szczególności Wspólnota powinna działać na rzecz redukcji zróżnicowań między regionami i ograniczenia zacofania słabiej uprzywilejowanych regionów”. Utworzenie wspólnego rynku (1988-1992) stanowiło istotny krok w integracji krajów Europy i niosło za sobą wiele korzyści społeczno-gospodarczych. Z drugiej jednak strony zwiększała się konkurencja pomiędzy podmiotami gospodarczymi, co mogło nieść za sobą negatywne konsekwencje dla regionów słabiej rozwiniętych ${ }^{10}$. Konieczne stało się podjęcie przez Unię Europejską działań o charakterze protekcyjnym, pozwalającym na dalszy rozwój i konkurowanie podmiotów gospodarczych z regionów słabiej rozwiniętych z tymi z centrów wzrostu.

8 A. Dubowska, Polityka regionalna Unii Europejskiej - ewolucja koncepcji w kontekście pogłębiania integracji, http://civitaseuropae.eu/wp-content/uploads/2009/02/anna_dubowska_ regiony.pdf [dostęp 03.03.2014].

9 K. Gawlikowska-Hueckel, A. Zielińska-Głębocka, Integracja europejska. Od jednolitego rynku do unii walutowej, Wydawnictwo C.H. Beck, Warszawa 2004, s. 197-198.

10 E. Łuków, Integracja gospodarcza i walutowa w Unii Europejskiej, XVIII Ogólnopolska Szkoła Europejska, Przemyśl 2001, s. 5. 
Kluczowym zagadnieniem z punktu widzenia prawidłowego funkcjonowania Europejskiego Funduszu Rozwoju Regionalnego było zdefiniowanie pojęcia „regionów słabiej rozwiniętych". W 1988 r. wprowadzono klasyfikację Nomenclature of Units for Territorial Statistics (NUTS), której celem było wprowadzenie wspólnego dla całej Unii Europejskiej podziału ułatwiającego gromadzenie danych statystycznych i pomoc regionom problemowym. Wyodrębniono trzy poziomy NUTS: NUTS 1 (makroregionów: 3 do 7 milionów mieszkańców), NUTS 2 (regiony: 800 tys. do 3 milionów mieszkańców), NUTS 3 (mniejsze jednostki podziału terytorialnego (150 tys. do 800 tys. mieszkańców) ${ }^{11}$. Ustanowiono również dwa poziomy bardziej szczegółowe Local Administrative Units (LAU) ${ }^{12}$.

W 1988 r. przeprowadzono reformę trzech funduszy strukturalnych i przyjęto zasadę sześcioletniego okresu programowania, który pokrywa się z ramami finansowymi Wspólnoty. Sformułowano również cele, które w następnych okresach programowania ewoluowały, dostosowując się do zmieniającej się sytuacji społeczno-gospodarczej ${ }^{13}$. Istotną reformą było odejście od systemu kwotowego na rzecz zasady współfinansowania (środki finansowe z Unii Europejskiej stanowiły od 25 do $75 \%$ kosztów projektu, a dla krajów kohezyjnych $80-85 \%)^{14}$.

Zasady polityki regionalnej zostały umocnione zapisami Traktatu o Unii Europejskiej (Traktat z Maastricht) z 7 lutego 1992 r. Artykuł 158 stwierdza: „wspierając wszechstronny, harmonijny rozwój UE będzie [...], dążyć do zredukowania różnic w stopniach rozwoju poszczególnych regionów, jak również zmniejszania zacofania najmniej uprzywilejowanych regionów"15. Na mocy Traktatu $z$ Maastricht powołano do życia Fundusz Spójności (Kohezji) i Europejski Instrument Wspierania Rybołówstwa. Utworzenie Funduszu Kohezji stanowiło odpowiedź na pogłębiające procesy integracji i wzrost poziomu konkurencji związany z realizacją Unii Gospodarczej i Walutowej ${ }^{16}$. Pomoc finansowa z Funduszu Spójności przeznaczona była na rzecz regionów, w których poziom PKB per capita jest niższy od 90\% średniej w Unii Europejskiej. Z kolei pomoc finansowa dla regionów położonych na terytoriach peryferyjnych pochodziła z Europejskiego Funduszu Inwestycyjnego. Traktat $z$ Maastricht utworzył rów-

11 A. Jarosz-Angowska, Zróżnicowanie regionalne gospodarki, http://www.studium.agrobizne su.up.lublin.pl/images/materialy/w2.pdf, s. 2-4 [dostęp 14.12.2012].

12 A. Osowska, NUTS (nowe jednostki terytorialne dla celów statystycznych), http://www.profe sor.pl/publikacja, 12299,Artykuly,NUTS-nowe-jednostki-terytorialne-do-celow-statystycz nych [dostęp 14.12.2012].

13 M. Dutkowski, Polityka regionalna w Unii Europejskiej, www.zpsb.szczecin.pl, s. 3-5 [dostęp 15.12.2012].

14 Ibidem, s. 4-8.

15 M. Klamut, Cele i narzędzia polityki regionalnej Unii Europejskiej, http://www.pzdu.pl/ uploads/files/konferencje/1/08_Miroslawa_Klamut.pdf [dostęp 15.01.2013].

16 A. Dąbrowski, Globalizacja a regionalizm, „Prace Naukowe Uniwersytetu Ekonomicznego we Wrocławiu", nr 244/2012, s. 366-373. 
nież Komitet Regionów, który stanowi swego rodzaju reprezentację regionów we władzach Unii Europejskiej.

Zmiany zachodzące w polityce regionalnej i kwestie rozszerzenia Unii Europejskiej o kraje z Europy Środkowo-Wschodniej wymagały wprowadzenia zmian w polityce regionalnej. Kolejny program działania Wspólnoty związany był z realizacją Agendy 2000. Do głównych zmian wprowadzonych podczas szczytu w Berlinie należy zaliczyć: zmniejszenie liczby inicjatyw wspólnotowych z trzynastu do czterech, nadanie charakteru funduszu strukturalnego Instrumentowi Wspierania Rybołówstwa, zmniejszenie liczby celów polityki regionalnej i wprowadzenie okresów przejściowych (pomoc na okres od 3 do 5 lat), ustalenie maksymalnego pułapu środków z funduszy strukturalnych i Funduszu Spójności, który nie mógł przekroczyć 4\% krajowego PKB (w skali roku) ${ }^{17}$.

W związku ze zbliżającym się rozszerzeniem Unii Europejskiej o kraje Europy Środkowo-Wschodniej zdecydowano się również na utworzenie dwóch instrumentów pomocy przedakcesyjnej: ISPA (Instrument for Structural Policies for Pre -accassion) i SAPARD (Support for Pre-accassion Measure for Agriculture and Rural Development) oraz kontynuację programu PHARE ${ }^{18}$.

Tabela 2.2. Instrumenty pomocy przedakcesyjnej

\begin{tabular}{|l|l|}
\hline $\begin{array}{l}\text { ISPA } \\
\text { (Przedakcesyjny Instrument } \\
\text { Polityki Strukturalnej) }\end{array}$ & $\begin{array}{l}\text { Powstał w celu zapewnienia pomocy krajom kandydującym } \\
\text { do członkostwa w UE (Krajom Europy Środkowej i Wschod- } \\
\text { niej). ISPA zapewnia wsparcie w realizacji założeń polityki } \\
\text { ochrony środowiska i polityki transportowej. Średnia alokacja } \\
\text { środków dla Polski od 2000 r. wyniosła 348 mln }\end{array}$ \\
\hline $\begin{array}{l}\text { SAPARD } \\
\text { (Specjalny Przedakcesyjny Pro- } \\
\text { gram na Rzecz Rolnictwa i Roz- } \\
\text { woju Obszarów Wiejskich) }\end{array}$ & $\begin{array}{l}\text { Instrument wsparcia dla krajów kandydujących do Unii Eu- } \\
\text { ropejskiej, ukierunkowany na realizację strukturalnych prze- } \\
\text { kształceń na wsi i przygotowanie krajów kandydujących do } \\
\text { korzystania ze Wspólnej Polityki Rolnej }\end{array}$ \\
\hline $\begin{array}{l}\text { PHARE } \\
\text { (Program Pomocy Polsce } \\
\text { i Węgrom w Restrukturyzacji } \\
\text { Gospodarki) }\end{array}$ & $\begin{array}{l}\text { Początkowo miał na celu wspieranie transformacji w Polsce } \\
\text { i na Węgrzech (1989), od 1990 r. objął również Czechy, Sło- } \\
\text { wację, a następnie Litwę, Łotwę, Estonię, Rumunię. Celem } \\
\text { programu było udzielanie pomocy krajom kandydującym do } \\
\text { Unii Europejskiej (od 2007 r. instrument pomocy przedakce- } \\
\text { syjnej) }\end{array}$ \\
\hline
\end{tabular}

Źródło: ISPA - ogólny podręcznik, Przedakcesyjny Instrument Polityki Strukturalnej Programowanie i Zasady Wdrażania w Polsce, http://bip.mi.gov.pl/pl/bip/integracja_europejska/fundusze/ispa/ px_zasady_wdrazania_ispa.pdf [dostęp 01.03.2014].

17 K. Gawlikowska-Hueckel, A. Zielińska-Głębocka, op. cit., s. 205.

18 Ministerstwo Finansów, Programy PHARE, ISPA, SAPARD,mf.gov.pl [dostęp 17.04.2014]. 
Okres programowania na lata 2007-2013 związany był z realizacją założeń Strategii Lizbońskiej ${ }^{19}$. Głównymi celami polityki regionalnej realizowanej w latach 2007-2013 było zapewnienie rozwoju gospodarczego i stworzenie nowych miejsc pracy. Na realizację założeń przeznaczono 347,4 mld euro. Ponad $80 \%$ z tej kwoty przekazane zostało na realizację celu pierwszego i objęło 35\% ludności Unii Europejskiej. Na realizację celu drugiego „Konkurencyjność regionalna i zatrudnienie” przeznaczono kwotę 55 mld euro, natomiast na cel trzeci „Europejska Współpraca Terytorialna" - 8,7 mld euro (współpraca transgraniczna, ponadnarodowa i międzyregionalna) ${ }^{20}$.

\subsubsection{Strategia Europa 2020}

Zmieniające się otoczenie społeczno-gospodarcze, globalizacja i konkurencja ze strony państw spoza kontynentu europejskiego spowodowały konieczność sformułowania nowego programu rozwoju dla Unii Europejskiej. Celem strategii Europa 2020 jest usunięcie słabych stron funkcjonowania Wspólnoty i zapewnienie stabilnego wzrostu dla całego ugrupowania ${ }^{21}$. Realizacja Strategii uwarunkowana jest przez rozwój inteligentny, rozwój zrównoważony oraz rozwój sprzyjający włączeniu społecznemu ${ }^{22}$. Strategia Europa 2020 wskazuje, że trzy wyżej wymienione cele powinny być realizowane jednocześnie, gdyż tylko takie podejście może zagwarantować stabilny rozwój społeczno-gospodarczy, a tym samym poprawę warunków i jakości życia obywateli. Wyraźny nacisk został położony na rolę innowacji i nowych technologii w zapewnieniu konkurencyjności Unii Europejskiej. Wzrost gospodarczy powinien odbywać się z poszanowaniem zasobów środowiska naturalnego oraz w oparciu o ich efektywne wykorzystanie. Duże znaczenie w kontekście strategii ma rozwój rynku pracy tak, aby poziom zatrudnienia w krajach unijnych był możliwie jak najwyższy. Strategia zawiera w sobie dwa komponenty: zadania wyrażone za pomocą liczb oraz tzw. inicjatywy flagowe ${ }^{23}$. Jej powo-

19 Ministerstwo Rozwoju Regionalnego, http://www.mrr.gov.pl/aktualnosci/rozwoj_regionalny/Strony/Reforma_polityki_spojnosci_wlatach07_13_Implikacie_FE_209.aspx [dostęp 12.01.2013].

20 http://ec.europa.eu/regional_policy/sources/docgener/presenta/working2008/work_ pl.pdf [dostęp 12.01.2013].

21 M. Greta, Euroregiony polskie w procesie integracji europejskiej oraz w przezwyciężaniu peryferyjności i dysproporcji regionalnych, Wydawnictwo Uniwersytetu Łódzkiego, Łódź 2013, s. 96-97.

22 Ministerstwo Rozwoju Regionalnego http://www.mrr.gov.pl/aktualnosci/rozwoj_regio nalny/Strony/Reforma_polityki_spojnosci_wlatach07_13_Implikacie_FE_209.aspx [dostęp 12.02.2013].

23 L.J. Jasiński, Uwagi na temat Strategii „Europa 2020", Aktualna prognoza makroekonomiczna INE-PAN, Konwersatorium o „Przyszłości Społecznej i Gospodarczej Polski” (13 maja 2010 r.), s. 1. 
dzenie zależeć będzie od osiągnięcia do 2020 r. następujących celów: wzrostu stopy zatrudnienia do $75 \%$, przeznaczeniu $3 \% \mathrm{PKB}$ na $\mathrm{B}+\mathrm{R}$, zmniejszeniu emisji $\mathrm{CO}_{2}$ o $20 \%$ w porównaniu z poziomem z 1990 r., zwiększeniu udziału odnawialnych źródeł energii w całkowitym zużyciu energii do $20 \%$, ograniczeniu wskaźnika przerywania nauki do 10\%, zwiększeniu odsetka osób w wieku 30-34 lat posiadających wyższe wykształcenie do co najmniej $40 \%$, ograniczeniu ubóstwa o $25 \%{ }^{24}$.

Strategia Europa 2020 stanowi ważny drogowskaz dla realizowanej w latach 2014-2020 polityki regionalnej Unii Europejskiej i ma być realizowana za pomocą inicjatyw: Innowacyjna Europa, Młodzi w ruchu, Digitalna agenda dla Europy, Oszczędzajaca zasoby Europa, Polityka przemystowa dla ery globalizacji, Agenda dla nowych umiejętności i miejsc pracy, Europejska platforma przeciw biedzie ${ }^{25}$.

Strategia wskazuje na działania w obrębie realizacji koncepcji zrównoważonego rozwoju (schemat 2.1). Na uwagę zasługuje fakt podniesienia konkurencyjności poprzez poprawę warunków funkcjonowania gospodarki rynkowej oraz wzrost wydajności przedsiębiorstw i handlu. Jednocześnie konieczne jest podejmowanie działań przeciwdziałających zmianom klimatu oraz zapewnienie czystych i odnawialnych źródeł energii.
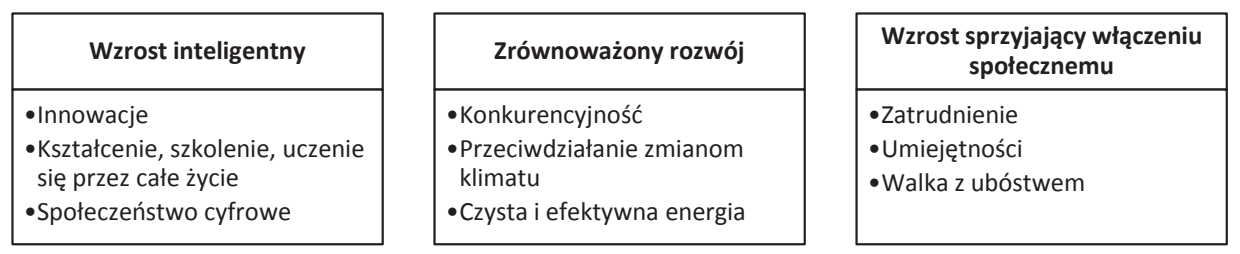

Schemat 2.1. Działania w ramach strategii Europa 2020

Źródło: M. Greta, Euroregiony polskie w procesie integracji europejskiej oraz w przezwyciężaniu peryferyjności i dysproporcji regionalnych, Wydawnictwo Uniwersytetu Łódzkiego, Łódź 2013, s. 96-97.

Z punktu widzenia wdrażania regionalnego wymiaru polityk rozwojowych w Unii Europejskiej strategia Europa 2020 napisana została w tradycyjnym nurcie ekonomii, w którym preferowane jest ujęcie sektorowe zamiast regionalnego ${ }^{26}$. Rozwój uwarunkowany jest kooperacją pomiędzy instytucjami wspólnotowymi a państwami człon-

24 Komunikat Komisji, EUROPA 2020 Strategia na rzecz inteligentnego i zrównoważonego rozwoju sprzyjającego włączeniu społecznemu, s. 12.

25 J. Szlachta, Strategia Europa 2020 a europejska polityka spójności po 2013 roku, http://kole gia.sgh.waw.pl/pl/KAE/struktura/IRG/publikacje/Documents/pim88_9.pdf, s. 237 [dostęp 01.03.2014].

26 J. Otto, T. Kostrzewa-Zielińska, M. Greta, Przedsiębiorczość w założeniach i realizacji Strategii lizbońskiej oraz w założeniach Strategii Europa 2020, „Zeszyty Naukowe Uniwersytetu Szczecińskiego", nr 63/2011, s. 65. 
kowskimi, zmniejszaniem negatywnego oddziaływania granic wewnętrznych oraz mobilnością czynników produkcji ${ }^{27}$. Strategia kładzie nacisk na zwiększanie potencjału innowacyjnego regionów. Dlatego konieczne jest zaangażowanie instytucji i podmiotów regionalnych oraz społeczności lokalnych w realizację jej założeńn ${ }^{28}$.

\subsubsection{Polityka regionalna Unii Europejskiej na lata 2014-2020}

Nowa perspektywa finansowa dla polityki regionalnej na lata 2014-2020 jest ściśle związana z realizowaną strategią Europa 2020. Jej podstawowy cel określony został w art. 3, zgodnie z którym: „Fundusze powinny wnosić wkład w rozwój i prowadzić działania UE mające na celu wzmocnienie spójności gospodarczej, społecznej i terytorialnej Unii”. Środki finansowe powinny przyczyniać się do realizacji priorytetowego celu Wspólnoty, jakim jest inteligentny i zrównoważony rozwój ${ }^{29}$.

W porównaniu z poprzednim okresem programowania na lata 2007-2013 liczbę celów polityki regionalnej zmniejszono do dwóch: Inwestycje w rozwój gospodarczy i wzrost zatrudnienia (96,9\% środków z polityki spójności - 364,3 mld EUR ze środków EFRR, EFS i FS) oraz Europejska współpraca terytorialna (11,7 mld EUR z EFRR, co stanowi 3,1\%) ${ }^{30}$. Przyjęto również listę celów tematycznych dla polityki regionalnej w oparciu o ramy strategii Europa 2020, w tym ${ }^{31}$ : wsparcie dla badań i rozwoju, zwiększenie dostępu do innowacji technologicznych i telekomunikacyjnych, wsparcie konkurencyjności sektorów: MŚP, rybołówstwa i rolnictwa, dostosowanie do zmian klimatycznych, ochrona środowiska naturalnego, zrównoważony transport, wzrost zatrudnienia i mobilności pracy, promocja włączenia społecznego, inwestycje w edukację, zwiększanie efektywności administracji publicznej.

W nowym okresie programowania polityki regionalnej na lata 2014-2020 położono nacisk na efektywność realizacji wyznaczonych celów, poprzez wprowadzanie oceny ex ante i ex post. Aby móc ubiegać się o środki finansowe $\mathrm{z}$ funduszy

27 J. Szlachta, Strategia Europa 2020..., s. 237.

28 M. Dziembała, Wspieranie innowacyjności gospodarek regionalnych w świetle Strategii Europa 2020, „Prace Naukowe Uniwersytetu Ekonomicznego w Katowicach”, nr 480/2013, s. 372.

29 J. Otto, T. Kostrzewa-Zielińska, M. Greta, Unijna polityka wsparcia sektora MSP elementem uwarunkowań międzynarodowej aktywności przedsiębiorstw, [w:] J. Witkor, A. Żbikowska (red.), Marketing międzynarodowy. Uwarunkowania i kierunki rozwoju, Wydawnictwo PWE, Warszawa 2010, s. 114.

30 J. Kudełko, Uwarunkowania rozwoju regionalnego w świetle założeń europejskiej polityki spójności na lata 2014-2020, "Studia Ekonomiczne. Uniwersytet Ekonomiczny w Katowicach”, nr 166/2014, s. 121.

31 Materiały Komisji Europejskiej, Polityka spójności 2014-2020. Inwestycje w rozwój gospodarczy i wzrost zatrudnienia, Urząd Publikacji Unii Europejskiej, Luksemburg 2011, s. 2-7. 
unijnych, koniecznie trzeba spełnić na wstępie określone warunki. Po wykonaniu określonego zadania dokonana będzie analiza efektów, która z kolei będzie czynnikiem warunkującym uzyskanie nowych unijnych środków pomocowych. Dodatkowym czynnikiem mobilizującym regiony i państwa jest nagradzanie tych z nich, które najlepiej wdrażają strategię Europa 2020. Środki finansowe z funduszy pomocowych kierowane są na trzy priorytetowe dziedziny: edukację, gospodarkę niskoemisyjną i energooszczędną oraz dbałość o „czynnik ludzki”32.

Na politykę regionalną w latach 2014-2020 przewidziano w sumie 376 mld EUR (37\% planowanego budżetu). $\mathrm{W}$ porównaniu $\mathrm{z}$ poprzednim okresem programowania budżet na politykę spójności wzrósł o 69 mld euro. Sposób rozdysponowania środków wskazuje na większe wsparcie dla regionów, które zgrupowano pod względem osiąganego PKB per capita na: regiony słabiej rozwinięte - PKB per capita poniżej 75\% średniej UE-27, regiony w fazie przejściowej - PKB per capita między 75 a 90\% średniej UE-27, regiony lepiej rozwinięte - PKB per capita powyżej 90\% średniej UE-27.

Jednocześnie zmieniły się priorytety finansowania projektów z Europejskiego Funduszu Rozwoju Regionalnego. Obligatoryjnie przewidziano, że w regionach lepiej rozwiniętych $80 \%$ środków ma być kierowane na działania zmierzające do rozwoju nowych technologii i innowacji, a 20\% na rozwój infrastruktury energetycznej i odnawialne źródła energii. W przypadku regionów słabiej rozwiniętych powyższy podział przedstawia się następująco: 50\% na innowacje i 50\% na energetykę.

Największy udział w finansowaniu z funduszy polityki spójności mają regiony najsłabiej rozwinięte, do których kierowane jest $43,2 \%$ wszystkich funduszy z polityki regionalnej. Nowym funduszem w perspektywie 2014-2020 jest instrument Łącząc Europę (Connecting Europe Facility - 29,3 mld euro), którego celem jest wsparcie finansowe projektów z zakresu infrastruktury, transportu, telekomunikacji i energetyki ${ }^{33}$.

Kierunek rozwoju polityki regionalnej w okresie programowania 2014-2020 wyraźnie wskazuje na coraz większe znaczenie czynników strukturalnych ${ }^{34}$. Realizowana polityka regionalna obejmuje następujące zagadnienia: inwestowanie we wszystkich regionach oraz określenie poziomu współfinansowania w zależności od poziomu rozwoju regionów, wsparcie kluczowych sektorów wzrostu, określenie zasad rozliczania celów, ustalenie założeń i warunków dotyczących uruchomienia środków finansowych w celu zapewnienia efektywności podejmowanych

32 M. Greta, Euroregiony polskie w procesie integracji europejskiej oraz w przezwyciężaniu peryferyjności i dysproporcji regionalnych, Wydawnictwo Uniwersytetu Łódzkiego, Łódź 2013, s. 101.

33 I. Komosa, Łq̨czq̨c Europę (Connecting Europe Facility), http://www.uniaeuropejska.org/qczceuropq-connecting-europe-facility [dostęp 10.12.2013].

34 M. Greta, K. Lewandowski, Euroregion jako instrument realizacji spójności społeczno-ekonomicznej i Strategii Lizbońskiej, „'Czasopisma Uniwersytetu Rzeszowskiego", z. 12/2008, s. 77. 
inwestycji, poprawę koordynacji podejmowanych działań, wsparcie miejscowego wymiaru podejmowanych działań, wsparcie współpracy transgranicznej, zwiększenie wsparcia dla małych i średnich przedsiębiorstw ${ }^{35}$.

\subsubsection{Zasady polityki regionalnej}

Implementacja polityki regionalnej dokonuje się poprzez działania mające na celu wyrównywanie dysproporcji w rozwoju poszczególnych regionów Unii Europejskiej poprzez stosowanie różnorodnych narzędzi oraz instrumentów ekonomicznych i prawnych. Z kolei zapewnienie jak najbardziej efektywnego zarządzania nimi wymagało wprowadzenia określonych zasad generalnych dotyczących funkcjonowania Wspólnoty oraz zasad operacyjnych traktujących o kształcie i funkcjonowaniu poszczególnych funduszy strukturalnych ${ }^{36}$.

Do nadrzędnych zasad polityki regionalnej należą: zasada koncentracji, dodatkowości, subsydiarności, programowania i partnerstwa. Zasada koncentracji wskazuje, że środki finansowe ze względu na ich ograniczenie należy skoncentrować na wybranych celach i regionach. Środki pochodzące z funduszy strukturalnych powinny służyć konkretnym celom polityki strukturalnej, szczególnie podkreśla się, że należy wspierać regiony najuboższe (Traktat $z$ Amsterdamu) ${ }^{37}$.

Zasada dodatkowości wskazuje, że środki z funduszy unijnych stanowią jedynie uzupełnienie realizowanych projektów. Nie pokrywają danych inwestycji w całości, są jedynie dodatkiem do środków będących w dyspozycji wnioskodawców ${ }^{38}$.

Zasada subsydiarności, określana również mianem zasady pomocniczości, podkreśla, że zadania powinny być realizowane na możliwie najniższym szczeblu, gdyż prowadzi to do lepszej efektywności i skuteczności realizowanych planów. Na szczeblu unijnym powinny być realizowane tylko te zadania, których jednostki samorządowe nie są w stanie wykonać ze względu na ich szeroki zakres.

Zasada programowania pokazuje, że środki finansowe $\mathrm{w}$ ramach polityki regionalnej ustalane są w określonym horyzoncie czasowym. Okresy programowania regionalnego pokrywają się z ramami finansowymi Wspólnoty (obecnie 7 lat).

Zasada partnerstwa podkreśla znaczenie kooperacji pomiędzy władzami Wspólnoty a jednostkami niższych szczebli samorządów terytorialnych w celu rozwoju społeczno-gospodarczego wszystkich regionów.

35 Ukierunkowanie polityki spójności UE na osiąganie maksymalnego wpływu na wzrost gospodarczy i zatrudnienie: European Commission, Reforma w 10 punktach - MEMO/13/1011, http://europa.eu/rapid/press-release_MEMO-13-1011_pl.htm [dostęp 19.11.2013].

36 A. Hołuj, D. Korecki, Uwarunkowania rozwoju regionalnego w Polsce, „Zeszyty Naukowe Wyższej Szkoły Ekonomicznej w Bochni", nr 7/2008, s. 25-26.

37 K. Michałek, B. Master, Jak fundusze europejskie zmieniaja Polskę. Scenariusz zajęć, Fundacja Viribus Unitis, Katowice 2009, s. 13.

38 A. Hołuj, D. Korecki, op. cit., s. 25. 
Wymienione zasady stanowią trzon realizowanej polityki regionalnej Unii Europejskiej. Należy jednak podkreślić, że każde państwo członkowskie poza unijną polityką, realizuje również swoją wewnętrzną politykę regionalną ukierunkowaną na wybrane i ściśle określone priorytetowe cele ${ }^{39}$.

\subsection{Instrumenty finansowe polityki regionalnej}

Instrumenty polityki regionalnej są narzędziami służącymi do realizacji celów określonych w programach unijnych. Środki z funduszy mają za zadanie wspieranie przemian społeczno-gospodarczych w regionach i sektorach gospodarki, które wyróżniają się słabszym tempem i poziomem rozwoju w relacji do średniego poziomu w Unii Europejskiej. Wyróżniono cztery rodzaje funduszy strukturalnych: Europejski Fundusz Rozwoju Regionalnego, Europejski Fundusz Społeczny, Europejski Fundusz Orientacji i Gwarancji Rolnej (zastąpiony przez Europejski Fundusz Rolny Rozwoju Obszarów Wiejskich oraz Europejski Fundusz Gwarancji Rolnej) oraz Finansowy Instrument Orientacji Rybołówstwa, wspierający rozwój sektora rybołówstwa (obecnie Europejski Fundusz Rybacki).

Funkcjonowanie unijnych funduszy strukturalnych oparte zostało od $1989 \mathrm{r}$. o następujące zasady ${ }^{40}$ : koncentracji środków, komplementarności, partnerstwa podejmowania działań $w$ ramach wieloletnich programów, wzmocnienie systemu kontroli i monitoringu. W $1988 \mathrm{r}$. przeprowadzono reformę dotyczącą finansowania funduszy strukturalnych. W pierwszym okresie finansowania w latach 19881993 przeznaczono 63 mld ECU dla wszystkich funduszy, wprowadzono zmianę celów i priorytetowych działań wspólnotowej polityki regionalnej. Wprowadzono koordynację wszystkich instrumentów finansowych, zasadę współfinansowania projektów przez wszystkie fundusze strukturalne oraz ustanowiono tzw. inicjatywy wspólnotowe.

Kolejna reforma została przeprowadzona w 1993 r. i skutkowała zmianami w finansowaniu funduszy strukturalnych. W latach 1994-1999 całkowity budżet funduszy strukturalnych wyniósł 140 mld ECU, z czego 72 mld ECU przekazano na rzecz Europejskiego Funduszu Rozwoju Regionalnego ${ }^{41}$.

39 K. Michałek, B. Master, op. cit., s. 13; Ministerstwo Rozwoju Regionalnego, Strategia Rozwoju Kraju 2007-2015, Warszawa 2012, s. 90-92.

40 D. Czykier-Wierzba, Finansowanie polityki regionalnej w Unii Europejskiej. Euro od A do Z, Narodowy Bank Polski, Warszawa 2003, s. 155-156.

41 Ibidem, s. 13. 
Na lata 2007-2013 Komisja przewidziała dwa fundusze strukturalne: Europejski Fundusz Rozwoju Regionalnego oraz Europejski Fundusz Społeczny. Ze środków EFRR finansowane są projekty zwiększające zatrudnienie, rozwój innowacyjności i przedsiębiorczości (priorytetem są małe i średnie przedsiębiorstwa), poprawę infrastruktury, ochronę środowiska naturalnego ${ }^{42}$. Budżet przeznaczony na realizację Konwergencji wynosi 81,7\%, na Regionalną konkurencyjność i zatrudnienie - 15,9\%, natomiast na Europejską Współpracę terytorialną - 2,4\% ${ }^{43}$.

W latach 2014-2020 na wydatki z Europejskiego Funduszu Rozwoju Regionalnego i Europejski Fundusz Spójności przewidziano w sumie 256 mld euro.

\subsubsection{Europejski Fundusz Rozwoju Regionalnego (EFRR)}

Europejski Fundusz Rozwoju Regionalnego utworzony został w 1975 r. w celu finansowania polityki regionalnej. Głównym jego zadaniem jest gromadzenie środków pieniężnych w celu zmniejszania dysproporcji w rozwoju poszczególnych regionów. W pierwszych pięciu latach funkcjonowania funduszu (1975-1980) środki finansowe kierowane były do wszystkich państw Wspólnoty i służyły refundacji wydatków ponoszonych na inwestycje z zakresu szeroko pojętej infrastruktury i przemysłu. W 1979 r. przeprowadzono reformę EFRR, w wyniku której fundusz ten stał się instrumentem wspólnotowym. Wydzielono do wyłącznej dyspozycji Komisji Europejskiej 5\% środków z Europejskiego Funduszu Rozwoju Regionalnego. Komisja mogła je przeznaczyć na realizację własnych, priorytetowych zadań. Reforma z 1979 r. nadała nowy, wspólnotowy charakter polityce regionalnej. Za kryterium przyznawania środków uznano długotrwały niedorozwój społeczno-gospodarczy, charakteryzujący się niskim poziomem dochodu per capita, wysoką stopą bezrobocia i wskaźnikiem migracji ${ }^{44}$. W 1985 r. wprowadzono minimalne i maksymalne pułapy transferów przekazywanych do poszczególnych państw członkowskich ${ }^{45}$.

W okresie programowania 2014-2020 EFRR ma za zadanie wsparcie rozwoju regionalnego i lokalnego poprzez realizację szczegółowych priorytetów, takich jak: wsparcie prac badawczo-rozwojowych, innowacje, rozwój technologii informacyjnych, telekomunikacyjnych, energetycznych, przejście na gospodarkę nisko-

42 http://20090209.archiwa.gov.pl/repository/wspolpraca/Fundusze_strukturalne.pdf [dostęp 15.05.2014].

43 W. Willak, Polityka spójności na lata 2007-2013, http://www.malopolskie.pl/Pliki/2006/4_ CONF24FEB2006WWillakPL.pdf, s. 10-14 [dostęp 16.05.2014].

44 http://ec.europa.eu/regional_policy/sources/docgener/presenta/working2008/work_ pl.pdf [dostęp 16.05.2015].

45 J. Szlachta, Europejski Fundusz Rozwoju Regionalnego - szansa dla Polski, http://www.bzfe. uw.gda.pl/download/Europejski\%20Fundusz\%20Rozwoju\%20Regionalnego.pdf [dostęp 15.05.2014]. 
emisyjną, poprawa efektywności administracji publicznej, zrównoważony rozwój miast, inwestycje w służbę zdrowia, rozwój ośrodków edukacyjnych ${ }^{46}$. EFRR jest instrumentem realizacji strategii Europa 2020, a jego priorytetowe zadania koncentrują się na badaniach, innowacjach, wsparciu małych i średnich przedsiębiorstw, rozwoju technologii informacyjnych i komunikacyjnych oraz wsparciu gospodarki niskoemisyjnej.

\subsubsection{Europejski Fundusz Społeczny (EFS)}

Europejski Fundusz Społeczny jest narzędziem finansowym Unii Europejskiej wspierającym rozwój społeczno-gospodarczy krajów członkowskich. EFS utworzony został na mocy postanowień Traktatu Rzymskiego w 1957 r. Odegrał szczególną rolę w momencie budowy jednolitego rynku wewnętrznego. To właśnie w 1988 r. określono jego podstawowe zadania, w tym m.in.: zawodowe wcielanie na rynek pracy, ochrona pracowników przed długoterminowym bezrobociem, kształcenie, dokształcanie, przeszkalanie, a także finansowanie praktyk i szkoleń wewnątrzzakładowych, kształcenie kadr, wyrównywanie szans kobiet i mężczyzn na rynku pracy, tworzenie miejsc pracy, promowanie nowych technologii ${ }^{47}$.

EFS realizuje swoje zadania za pomocą programów operacyjnych. Podlega on bezpośredniej kontroli ze strony Komisji Europejskiej ${ }^{48}$. Wsparcie z Funduszu wynosi od 50 do $85 \%$ całkowitych kosztów danej inwestycji. Głównym celem Europejskiego Funduszu Społecznego w latach 2000-2013 był: wzrost zatrudnienia, promocja innowacyjności, realizacja szkoleń z zakresu know-how oraz zapewnienie elastyczności na rynku pracy ${ }^{49}$. Ważna jest również jego rola w aktywizacji ludzi starszych, zapewnieniu rozwoju zawodowego, równości szans na rynku pracy czy wsparciu przedsiębiorczości ${ }^{50}$. Działania EFS są zbieżne z realizowaną przez Unię Europejską strategią Europa 2020 oraz Strategia na rzecz wzrostu gospodarczego i zatrudnienia ${ }^{51}$.

46 Polityka spójności 2014-2020. Inwestycje w rozwój gospodarczy i wzrost zatrudnienia, http://ec.europa.eu/regional_policy/sources/docoffic/official/regulation/pdf/2014/propo sals/regulation2014_leaflet_pl.pdf [dostęp 15.05.2014].

47 Centrum Informacji Europejskiej MSZ, http://www.cie.gov.pl/publikacje/fi/docs/europej. pdf [dostęp 12.01.2013]

48 Komisja Europejska, Europejski Fundusz Społeczny, http://ec.europa.eu/employment_so cial/esf/discover/participate_en.htm [dostęp 10.05.2014].

49 http://uniaeuropejska.org/unia/files/encyklopedia/EFS_MKarapuda_\%20FKE.pdf, s. 4-5 [dostęp 12.01.2013].

50 http://ec.europa.eu/employment_social/esf/docs/esf_leaflet_pl.pdf, s. 4 [dostęp 12.01.2013].

51 Ministerstwo Gospodarki i Pracy, Kwalifikowalność wydatków w ramach Europejskiego Funduszu Społecznego, 2005, http://www.wup-rzeszow.pl/sporzl/files/63_WytyczneEFS_aktua lizacja180306.pdf, s. 5-7 [dostęp 10.05.2014]. 
W okresie programowania 2014-2020 znaczenie Europejskiego Funduszu Społecznego uległo zwiększeniu, czego przejawem są: określenie minimalnego udziału EFS w finansowaniu inwestycji w kapitał ludzki, wsparcie dla równouprawnienia kobiet i mężczyzn, określenie, że 20\% z całej puli środków zgromadzonych w EFS ma być przeznaczonych na walkę $\mathrm{z}$ wykluczeniem społecznym, walka $\mathrm{z}$ bezrobociem w szczególności wśród ludzi młodych (minimum 6,4 mld euro na gwarancje dla młodzieży), zwiększenie efektywności funduszu poprzez zmniejszenie liczby celów oraz wprowadzenie nowych, innowacyjnych zasad zarządzania środkami z EFS ${ }^{52}$. Podstawowymi celami Europejskiego Funduszu Społecznego na lata 2014-2020 są: pomoc w znalezieniu zatrudnienia, włączenie społeczne, lepsza edukacja. Te zadania niosą za sobą konieczność wzmocnienia i wsparcia administracji publicznej.

\subsubsection{Europejski Fundusz Orientacji i Gwarancji Rolnej}

Europejski Fundusz Orientacji i Gwarancji Rolnej powstał na mocy postanowień Traktatu ustanawiajacego Wspólnotę Gospodarcza w 1964 r. Sekcja Orientacji zaliczana jest do Funduszy Strukturalnych, a zakres jej działań obejmuje m.in. restrukturyzację i poprawę funkcjonowania gospodarstw rolnych, wdrażanie nowych technologii przy produkcji rolnej, wsparcie terenów leśnych, tworzenie nowych miejsc pracy na obszarach wiejskich, inwestycje w ochronę środowiska naturalnego. Ze środków Europejskiego Funduszu Orientacji i Gwarancji Rolnej w ramach Sekcji Orientacji finansowany jest Sektorowy Program Operacyjny Restrukturyzacja i Modernizacja Sektora Żywnościowego oraz Rozwój Obszarów Wiejskich ${ }^{53}$. Od 2007 r. Fundusz ten został zastąpiony przez dwa nowe - Europejski Fundusz Rolny Rozwoju Obszarów Wiejskich oraz Europejski Fundusz Gwarancji Rolnej.

\subsubsection{Finansowy Instrument Orientacji Rybołówstwa}

Finansowy Instrument Orientacji Rybołówstwa utworzony został w 1993 r. $\mathrm{w}$ celu realizacji zadań związanych w szczególności z adaptacją polityki strukturalnej w rybołówstwie. $Z$ wykorzystaniem FIOR-u finansowane są inicjatywy w następujących dziedzinach: rozwój hodowli ryb, rozwój portów rybackich poprzez zapewnienie odpowiedniej infrastruktury, rozwój i unowocześnianie floty rybackiej, metod połowu ryb, wzrost konkurencyjności unijnych produktów rybnych, promocja i reklama produktów związanych $\mathrm{z}$ rybołówstwem. $\mathrm{W}$ okresie progra-

52 Europejski Fundusz Społeczny, http://ec.europa.eu/esf/main.jsp?catld=62\&langld=pl [dostęp 15.01.2013].

53 EFOiGR, czyli Europejski Fundusz Orientacji i Gwarancji Rolnej, http://www.portfel.pl/pdf/ art773 [dostęp 17.03.2013]. 
mowania 2007-2013 FIOR został zastąpiony przez Europejski Fundusz Rybacki, którego celem jest zapewnienie finansowania sektorowi rybołówstwa i społecznościom nadbrzeżnym.

\subsubsection{Fundusz Spójności}

Fundusz Spójności powstał na mocy Traktatu z Maastricht w celu zmniejszania różnic w poziomie rozwoju społeczno-gospodarczego krajów i regionów Unii Europejskiej. Środki finansowe z Funduszu Kohezji przyznawane są państwom członkowskim, których PKB per capita jest niższy od 90\% średniej dla Unii Europejskiej ${ }^{54}$. Fundusz Kohezji jest jednym z głównych narzędzi realizacji spójności społeczno-gospodarczej. Z Funduszu finansowane są duże projekty z zakresu infrastruktury transportowej i ochrony środowiska o wartości przekraczającej $10 \mathrm{mln}$ euro. Środki finansowe Funduszu Spójności podzielone są na dwie równe części: na ochronę środowiska i na infrastrukturę transportową ${ }^{55}$. W okresie programowania przypadającym na lata 2000-2006 środki pomocowe z Funduszu Kohezji otrzymywały Grecja, Hiszpania, Irlandia, Portugalia oraz wszystkie dziesięć państw, które przystąpiły do Unii Europejskiej w 2004 r. W okresie programowania 2007-2013 środki udostępnione w ramach funduszy strukturalnych i Funduszu Spójności wyniosły 336,1 mld euro.

Fundusz Spójności jest instrumentem realizacji spójności społeczno-gospodarczej, natomiast nie jest zaliczany do funduszy strukturalnych. Środki finansowe z Funduszu Spójności przekazywane są na pomoc krajom, natomiast fundusze strukturalne zapewniają rozwój regionów ${ }^{56}$. Podstawowym celem Funduszu Kohezji jest wzmacnianie kohezji społeczno-gospodarczej poprzez finansowanie projektów z zakresu ochrony środowiska i infrastruktury transportowej ${ }^{57}$.

W okresie programowania na lata 2014-2020 w ramach Funduszu Spójności przeznaczonych zostało 63,4 mld euro na transeuropejskie sieci transportowe (środki finansowe w ramach Funduszu Spójności przekazywane są na realizację projektów infrastrukturalnych w ramach instrumentu Łącząc Europę) oraz środowisko ( $w$ tym projektów związanych z energetyką, transportem, odnawialnymi

54 S. Konopacki, Polska pięć lat w Unii Europejskiej, Wydawnictwo Ibidem, Łódź 2009, s. $254-257$.

55 http://www.funduszspojnosci.gov.pl/Podstawowe+informacje/ [dostęp12.05.2013].

56 A. Jankowska, Fundusze Unii Europejskiej w okresie programowania na lata 2007-2013, Polska Agencja Rozwoju Przedsiębiorczości, Warszawa 2005, s. 12.

57 L.J. Jasiński, Globalna pozycja Unii Europejskiej w dłuższej perspektywie, „Studia Europejskie. Centrum Europejskie Uniwersytetu Warszawskiego", nr 4(72)/2014, s. 182. 
źródłami energii). W obecnym okresie programowania z Funduszu Spójności korzystają: Litwa, Łotwa, Estonia, Polska, Czechy, Słowacja, Węgry, Cypr, Bułgaria, Rumunia, Chorwacja, Portugalia, Słowenia, Grecja, Malta ${ }^{58}$.

\subsection{Inicjatywy Wspólnotowe jako narzędzie dla zrównoważonego rozwoju euroregionów}

U podstaw stworzenia finansowego wsparcia współpracy transgranicznej w Unii Europejskiej leżało przekonanie, że wyrównywanie dysproporcji w rozwoju poszczególnych regionów i krajów ułatwi przechodzenie do dalszych etapów integracji ${ }^{59}$. Szczególną rolę w finansowaniu współpracy transgranicznej ze środków unijnych odegrały programy Interreg i PHARE. Program PHARE (Poland and Hungary Assistance for Reconstructing of their Economies) powstał w 1989 r., a jego głównym zadaniem było wsparcie przemian gospodarczych, społecznych i politycznych zachodzących w Polsce i na Węgrzech.

Tabela 2.3. Ewolucja programu PHARE

\begin{tabular}{|c|l|l|}
\hline $\begin{array}{c}\text { Okres I } \\
(1989-1991)\end{array}$ & pomoc humanitarna & $\begin{array}{l}\text { Działania te służyć miały rozwiązywaniu prob- } \\
\text { lemów wynikających z przystosowania państw } \\
\text { do wdrożenia gospodarki rynkowej, dlatego też } \\
\text { dominowała wówczas pomoc towarowa, po- } \\
\text { zwalająca zrównoważyć niedostatki rynkowe } \\
\text { w kilku dziedzinach gospodarki. }\end{array}$ \\
\hline $\begin{array}{c}\text { Okres II } \\
(1991-1993)\end{array}$ & $\begin{array}{l}\text { Po 1991 r. program PHARE został skierowany na } \\
\text { reformowanie polskiej gospodarki. W tym okre- } \\
\text { sie przeważała pomoc doradcza i szkoleniowa. } \\
\text { Jej celem było przygotowanie najważniejszych } \\
\text { sektorów gospodarki do warunków wolnego } \\
\text { rynku. }\end{array}$ \\
\hline $\begin{array}{l}\text { Okres III } \\
\text { i szoleniowa }\end{array}$ & $\begin{array}{l}\text { Pomoc zaczęła służyć finansowaniu inwestycji } \\
\text { w określonych sektorach gospodarki (ochrona } \\
\text { środowiska, transport, rolnictwo, rozwój regio- } \\
\text { nalny). Dominowała przede wszystkim pomoc } \\
\text { w rozwoju infrastruktury dróg, sieci kolei i tele- } \\
\text { komunikacji oraz rozwoju regionów słabo roz- } \\
\text { winiętych. }\end{array}$ \\
\hline
\end{tabular}

Źródło: http://blog.matrus.pl/2-2-ewolucja-funduszu-phare [dostęp 12.02.2013].

58 Fundusz Spójności, http://ec.europa.eu/regional_policy/thefunds/cohesion/index_pl.cfm [dostęp 12.02.2013].

59 Główny Urząd Statystyczny, Instrumenty finansowe Unii Europejskiej wspierajace współpracę transgraniczna, http://www.stat.gov.pl/cps/rde/xbcr/wroc/ASSETS_31-42.pdf, s. 31 [dostęp 12.02.2013]. 
Wsparcie finansowe $\mathrm{w}$ ramach programu PHARE objęło w późniejszym okresie również pozostałe państwa Europy Środkowo-Wschodniej. W 1997 r. zostało uznane za instrument pomocy przedakcesyjnej. Z punktu widzenia współpracy transgranicznej ważnym krokiem podjętym w $1994 \mathrm{r}$. było utworzenie $\mathrm{w}$ ramach PHARE Programu Współpracy Przygranicznej PHARE CBC, którego celem było wsparcie współpracy regionów przygranicznych państw Europy Środkowej i Wschodniej z państwami członkowskimi Wspólnoty. Na ten cel, który służyć miał pogłębianiu integracji, przeznaczono 1/4 środków z programu PHARE. Poza programem PHARE CBC powstały również programy: PHARE CREDO wspierający współpracę terenów przygranicznych pomiędzy państwami Europy Środkowo-Wschodniej oraz PHARE TACIS wspierający finansowo współpracę transgraniczną państw należących do Wspólnoty Niepodległych Państw ${ }^{60}$.

Pomoc finansowa udzielana z programu PHARE obejmuje szeroki zakres działalności, a jej elastyczność pozwala dostosować się do charakteru przemian i reform wdrażanych w państwach uczestniczących w programie. Wsparcie dotyczy przede wszystkim działań i dziedzin związanych ze zmianami prawnymi, których celem jest stworzenie demokratycznego społeczeństwa obywatelskiego. Szeroki zakres funkcjonowania programu PHARE powoduje, że z jego środków wspierane są przedsięwzięcia dotyczące inwestycji w infrastrukturę, rozwój małych i średnich przedsiębiorstw, działania zmierzające do wsparcia współpracy transgranicznej.

Podwyższanie spójności społeczno-gospodarczej odbywa się również przy użyciu inicjatyw wspólnotowych. Największą inicjatywą wspierającą rozwój współpracy transgranicznej jest program Interreg. Funkcjonował on w Unii Europejskiej w trzech edycjach, na przestrzeni lat 1991-2006. Z jego środków finansowana jest również współpraca międzynarodowa i międzyregionalna.

Tabela 2.4. Edycje Programu Interreg

\begin{tabular}{|c|c|c|}
\hline $\begin{array}{l}\text { Program } \\
\text { Interreg I } \\
1991-1993\end{array}$ & $1082 \mathrm{mln}$ euro & $\begin{array}{l}\text { Realizowano trzy cele: pomoc obszarom granicznym } \\
\text { w przezwyciężaniu peryferyjności, rozwój współpracy } \\
\text { transgranicznej na wewnętrznych granicach Unii Europej- } \\
\text { skiej oraz stymulowanie współpracy na zewnętrznych gra- } \\
\text { nicach UE z partnerami krajów trzecich. }\end{array}$ \\
\hline $\begin{array}{l}\text { Program } \\
\text { Interreg II } \\
1994-1999\end{array}$ & $3525 \mathrm{mln}$ euro & $\begin{array}{l}\text { Realizowano następujące cele: wspomaganie zintegrowa- } \\
\text { nego rozwoju współpracy transgranicznej i przezwycięża- } \\
\text { nie istniejących w tym obszarze problemów (komponent } \\
\text { A), likwidowanie luk w transeuropejskich sieciach transpor- } \\
\text { towych i energetycznych (komponent B), stworzenie wa- } \\
\text { runków do zrównoważonego rozwoju Europy w kontek- } \\
\text { ście planowania przestrzennego oraz gospodarki wodnej } \\
\text { (komponent C). }\end{array}$ \\
\hline $\begin{array}{l}\text { Program } \\
\text { Interreg III } \\
2000-2006\end{array}$ & $4875 \mathrm{mln}$ euro & $\begin{array}{l}\text { Wydzielono trzy komponenty: A - współpraca transgra- } \\
\text { niczna, B - współpraca transnarodowa, C - współpraca } \\
\text { międzyregionalna. }\end{array}$ \\
\hline
\end{tabular}

Źródło: http://www.stat.gov.pl/cps/rde/xbcr/wroc/ASSETS_31-42.pdf, s. 40 [dostęp 10.05.2014]. 
Na program Interreg I, który realizowany był w latach 1991-1993, przewidziano 1082 mln euro, na Interreg II w latach 1994-1999 - 3525 mln euro, a na Interreg III - 4875 mln euro. Podstawowe cele poszczególnych edycji programu przedstawiono w tabeli 2.4.

W okresie programowania na lata 2007-2013 po raz pierwszy zdecydowano się uznać współpracę transgraniczną ukierunkowaną na harmonijne pogłębianie integracji terytorium Unii Europejskiej za jeden z celów polityki regionalnej. Cel ten nazwano Europejska Współpraca Terytorialna.

Programy w ramach Europejskiej Współpracy Terytorialnej obejmują zintegrowane zamierzenia dotyczące priorytetów działania Unii Europejskiej, które są finansowane z Europejskiego Funduszu Rozwoju Regionalnego. Wsparcie współpracy transgranicznej w latach 2007-2013 objęło: unijne zewnętrzne regiony przygraniczne, niektóre wybrane regiony zlokalizowane przy granicach wewnętrznych oraz określone regiony położone przy granicach morskich (NUTS III) ${ }^{61}$.

Wyodrębnienie współpracy transgranicznej jako odrębnego celu polityki regionalnej potwierdza znaczenie i rolę tej formy kooperacji dla zwiększania spójności społeczno-gospodarczej. Na współpracę transgraniczną zwiększono również środki finansowe w ramach Europejskiego Funduszu Rozwoju Regionalnego. W latach 2007-2013 przeznaczono w sumie kwotę w wysokości 7,75 mld euro. Realizacja polityki współpracy transgranicznej w latach 2007-2013 jest kontynuacją inicjatywy Interreg i jest wdrażana poprzez realizację trzech programów operacyjnych:

- współpracy transgranicznej (kontynuacja Interreg IIIA) ukierunkowanej na rozwój inicjatyw lokalnych i regionalnych,

- współpracy transnarodowej (kontynuacja Interreg IIIB) ukierunkowanej na wspieranie rozwoju obszarów miejskich, innowacyjność, ochronę środowiska naturalnego tak, by zwiększyć integrację terytorialną w ramach Unii Europejskiej,

- współpracy międzyregionalnej (kontynuacja (Interreg IVC) zapewniającej wymianę doświadczeń w zakresie innowacyjności ${ }^{62}$.

Beneficjentami programów finansowanych w ramach Europejskiej Współpracy Terytorialnej na lata 2014-2020 są władze lokalne i regionalne, szkoły wyższe, euroregiony, organizacje pozarządowe, instytucje badawcze, centra innowacyjności, organizacje non profit i wiele innych ${ }^{63}$. Beneficjenci EWT mogą realizować szereg projektów wpływających na zwiększanie spójności społeczno-ekonomicznej

61 A. Jankowska, Fundusze Unii Europejskiej w okresie programowania 2007-2013, Polska Agencja Rozwoju Przedsiębiorczości, Warszawa 2005.

62 Urząd Marszałkowski Województwa Zachodniopomorskiego, Europejska Współpraca Terytorialna 2007-2013, http://www.ewt.wzp.pl/ewt/ewt_2007-2013/europejska_wspolpraca_te rytorialna_2007_-_2013.htm [dostęp 02.03.2013].

63 http://www.ewt.gov.pl/WstepDoFunduszyEuropejskich/Strony/Beneficjenci.aspx [dostęp 02.03.2013]. 
w regionach, w tym np. rozwój bazy i oferty turystycznej, transgraniczne projekty infrastrukturalne, ochronę zabytków, przedsięwzięcia kulturalne i projekty naukowe. Inicjatywa skierowana jest również na wsparcie integracji oraz wykorzystanie dotychczasowych rezultatów, osiągniętych w zakresie innowacyjności przedsiębiorstw i klastrów, w tym inicjatywy „Region wiedzy”.

\subsection{Rola polityki regionalnej Unii Europejskiej w niwelowaniu różnic rozwojowych}

Polityka regionalna w ostatnich latach nabrała olbrzymiego znaczenia, a nurt proregionalny stał się głównym elementem realizowanej polityki gospodarczej UE. Analizy i statystyki dotyczące efektów realizacji celów polityki regionalnej wyraźnie wskazują, że przynosi ona widoczne efekty. W pierwszym okresie programowania wskaźnik poziomu PKB per capita uległ wyraźnej poprawie, a dysproporcje pomiędzy regionami w UE zmniejszyły się o 3\% oraz o kolejne $5 \%$ w drugim okresie programowania w latach 1994-1999. W latach 2000-2006 podkreślono znaczenie zwiększania poziomu konkurencyjności regionów o niższym poziomie rozwoju gospodarczego, dlatego $90 \%$ środków z funduszy strukturalnych przeznaczono na ten właśnie cel (rozwój infrastruktury $1 / 3$ środków, rozwój zasobów ludzkich $1 / 4$ środków i $1 / 3$ na wspieranie rolnictwa ${ }^{64}$. Dokonując analizy ex post, należy stwierdzić, że dzięki środkom finansowym pochodzącym z EFRR powstało $24 \%$ autostrad zbudowanych w tym okresie. Do sieci wodociągowej podłączono ok. 14 mln ludzi, a do urządzeń uzdatniania wody szacunkowo - 20,5 mln użytkowników. Dzięki wsparciu sektora małych i średnich przedsiębiorstw powstało około 638 tys. nowych miejsc pracy. Niewątpliwie widoczne są sukcesy realizowanej polityki regionalnej, natomiast należy pamiętać, że wiele rzeczy wymaga zreformowania i horyzontalnego podejścia zarówno do celów, jak i zmieniającej się sytuacji społeczno-gospodarczej. Okres programowania na lata 2007-2013 był szczególnie trudny. Unia Europejska stanęła przed koniecznością nie tylko realizacji własnych celów społeczno-gospodarczych, lecz także przed światowym kryzysem gospodarczym. Wydaje się jednak, że polityka regionalna winna być realizowana w podobnym zakresie jak dotychczas. Realizacja unijnej polityki regionalnej w latach 2014-2020 bezpośrednio związana jest ze strategią Europa 2020. Na plan pierwszy wśród celów na obecny okres wybija się położenie nacisku na innowacyjność oraz wdrażanie nowych technologii.

64 Komisja Europejska, Unity, Solidarity, Diversity for Europe, its People and its Territory. Second Report on Economic and Social Kohesion, Statistical Annex, Brussels, January 2001, s. 56. 
Regionalizacja unijnej polityki gospodarczej wpływa w znacznym stopniu na wzrost konkurencyjności poszczególnych regionów, a tym samym powoduje, że stają się one bardziej samodzielne i mają możliwość wpływania na rozwój poszczególnych krajów członkowskich. Mechanizm polityki realizowanej przez Unię Europejską sprzyja powstawaniu silnych regionów odgrywających znaczącą rolę w polityce międzynarodowej ${ }^{65}$. Jak pisze B. Woś, proces wzrostu roli europejskich regionów w polityce gospodarczej wydaje się nieunikniony i nieuchronny. Podkreśla on również dwie główne tendencje, pierwszą jest wzrost podmiotowości regionów poprzez obecnie prowadzoną politykę strukturalną Unii Europejskiej, drugą jest zwiększenie aktywności regionów w zakresie przeobrażeń społeczno-gospodarczych na ich obszarze. Komisja Europejska dąży do tego, aby władze regionalne prowadziły możliwie jak największy zakres własnych działań wspierających zwiększanie spójności społeczno-gospodarczej w regionach najuboższych ${ }^{66}$.

\subsection{Uwagi końcowe}

Celem polityki regionalnej Unii Europejskiej jest pomoc regionom słabiej rozwiniętym lub opóźnionym, a przez to zmniejszanie dysproporcji w poziomie i jakości życia w całej Wspólnocie. Polityka regionalna jest jedną z ważniejszych polityk Unii Europejskiej, a fundusze na jej finansowanie zatwierdzane są w ramach okresów budżetowych. Ewolucja instrumentów polityki regionalnej wyraźnie wskazuje, że władze unijne dążą do jak najbardziej efektywnego ich wykorzystania, a zarazem takiego ukierunkowania, aby zwiększyć spójność społeczną, gospodarczą i terytorialną w Unii Europejskiej. Jednocześnie wyraźnie widać, że w okresie programowania na lata 2014-2020 rozwój regionów uwarunkowany jest przez podejmowanie działań $\mathrm{w}$ zakresie nowych technologii, innowacji, badań i rozwoju. Ukierunkowanie funduszy unijnych na zwiększanie inwestycji w nowe technologie jest zgodne ze strategią Europa 2020, której głównym celem jest unowocześnienie europejskiej gospodarki tak, by mogła ona konkurować z innymi światowymi potęgami.

65 W. Toczyski, W. Sartorius, J. Zaucha, Międzynarodowa współpraca regionów. Wybór ekspertyz, Przedświt, Warszawa 1997, s. 26-27.

66 B. Woś, Europejska integracja a podmiotowość regionów, [w:] Z. Mikołajewicz (red.), Uwarunkowania i strategie rozwoju regionalnego w procesach europejskiej integracji, Wydawnictwo Uniwersytetu Opolskiego, Opole 2000, s. 107-115. 



\section{Rozdział 3}

\section{Euroregion jako szczególna forma współpracy transgranicznej}

\subsection{Uwagi wstępne}

Współpraca transgraniczna pomiędzy regionami przygranicznymi jest nieodzownym elementem realizacji koncepcji stałego i zrównoważonego rozwoju. Ma ona na celu eliminowanie negatywnych skutków istnienia granic państwowych i wspieranie rozwoju obszarów peryferyjnych. Zinstytucjonalizowaną formą współpracy transgranicznej są euroregiony, które dzięki wyodrębnieniu odpowiednich struktur organizacyjnych zapewniają skoordynowany rozwój obszarów przygranicznych, oparty na wsparciu finansowym z Unii Europejskiej. Rozdział 3 zawiera zarys problematyki współpracy transgranicznej w Unii Europejskiej. Zdefiniowany został region przygraniczny oraz podstawowe zagadnienia teoretyczne i specyfika współpracy euroregionalnej. Podjęto próbę odowiedzi na pytanie: Czy euroregion dzięki odpowiedniej strukturze organizacyjnej i realizowanym strategiom przyczynia się do aktywizacji terenów przygranicznych?

\subsection{Współpraca transgraniczna - pojęcie, cele, zakres}

Współpraca transgraniczna oznacza współdziałanie pomiędzy regionami przygranicznymi. Idea współpracy pomiędzy lokalnymi i regionalnymi społecznościami narodziła się w latach 50. XX w. w Europie Zachodniej. Rozpoczęły ją regiony graniczne Holandii i Niemiec oraz Niemiec i Francji. Następnie wraz z rozwojem i zmianami zachodzącymi w stosunkach międzynarodowych w Europie współpracę transgraniczną nawiązały regiony przygraniczne Grecji, 
Hiszpanii i Portugalii, a po przemianach ustrojowych pod koniec lat 80 . i na początku lat 90. XX w. również regiony przygraniczne w Europie Środkowej i Wschodniej'.

\subsubsection{Konceptualizacja pojęcia współpraca transgraniczna}

Współpraca pomiędzy regionami coraz częściej określana jest jako współpraca terytorialna, w ramach której można wyodrębnić trzy składowe: współpracę transgraniczną określaną często mianem przygranicznej (cross-border), międzyregionalną (interregional), ponadnarodową (transnational).

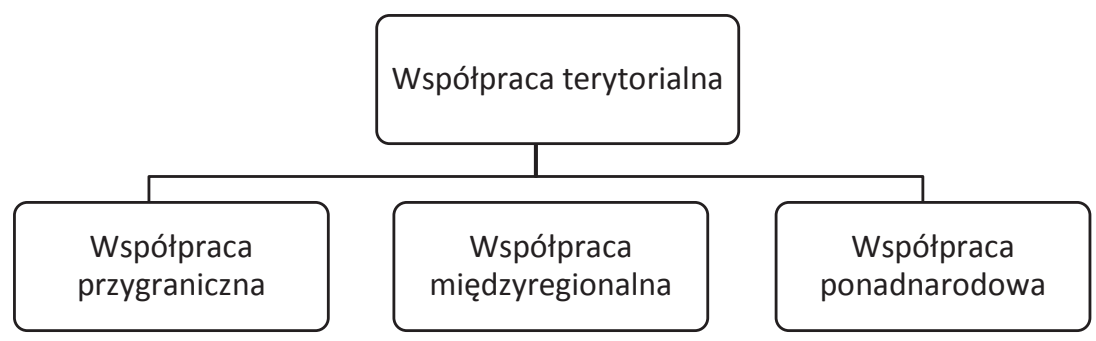

Schemat 3.1. Rodzaje współpracy terytorialnej

Źródło: P.R. Krugman, M. Obstfeld, Ekonomia międzynarodowa. Teoria i polityka, t. 2, Wydawnictwo Naukowe PWN, Warszawa 2007, s. 423-424.

Współpraca międzyregionalna jest formą współpracy pomiędzy jednostkami terytorialnymi i podmiotami szczebla regionalnego i lokalnego, które nie są położone w bezpośrednim sąsiedztwie. Ta forma współpracy dotyczy zazwyczaj regionów o mniejszej powierzchni. Współpraca transnarodowa $\mathrm{z}$ kolei jest prowadzona przez podmioty regionalne i lokalne na większych obszarach (np. współpraca państw Krajów Beneluksu, Europy Środkowo-Wschodniej, państw basenu Morza Bałtyckiego). Szczególną formą współpracy terytorialnej jest współpraca transgraniczna ${ }^{2}$. Jej celem są „wszelkiego rodzaju pokojowe międzynarodowe stosunki, mające na celu wzajemne korzyści”’3. Zgodnie z zapisami Europejskiej Konwencji Ramowej o współpracy transgranicznej między wspólnotami i władzami terytorialnymi współpraca transgraniczna to „każde wspólnie podjęte działanie mające na celu umocnienie sąsiedzkich kontaktów między wspólnotami i władzami

1 Główny Urząd Statystyczny, Współpraca transgraniczna w Europie, http://www.stat.gov.pl/ cps/rde/xbcr/wroc/ASSETS_14-19.pdf, s. 14 [dostęp 20.05.2014].

2 P.R. Krugman, M. Obstfeld, Ekonomia międzynarodowa. Teoria i polityka, t. 2, Wydawnictwo Naukowe PWN, Warszawa 2007, s. 423-424.

3 E.J. Osmańczyk, Encyklopedia spraw międzynarodowych i ONZ, PWN, Warszawa 1974, s. 1008. 
terytorialnymi dwóch lub większej liczby umawiających się stron”4. Współpraca transgraniczna odbywa się w ramach regionów przygranicznych i transgranicznych. Region przygraniczny to region umiejscowiony po jednej stronie granicy państwowej ${ }^{5}$. Może on być również postrzegany jako obszar lub terytorium położone w sąsiedztwie granicy państwa ${ }^{6}$.

Region transgraniczny obejmuje terytorium przekraczające co najmniej jedną granicę państwową. Charakteryzuje się występowaniem szeregu współzależności gospodarczych oraz wspólnoty więzi społecznych pomiędzy mieszkańcami. Region transgraniczny to obszar po obu stronach granicy, w którym, jak pisze M. Fic, „ludność chce współpracować, by pobudzać postęp kulturalny, społeczny i gospodarczy"7. Czynnikami delimitacji regionów transgranicznych są przede wszystkim: stopień homogeniczności i ich położenie, status i poziom rozwoju, stopień formalizacji granic państwowych, skala instytucjonalizacji współpracy ${ }^{8}$.
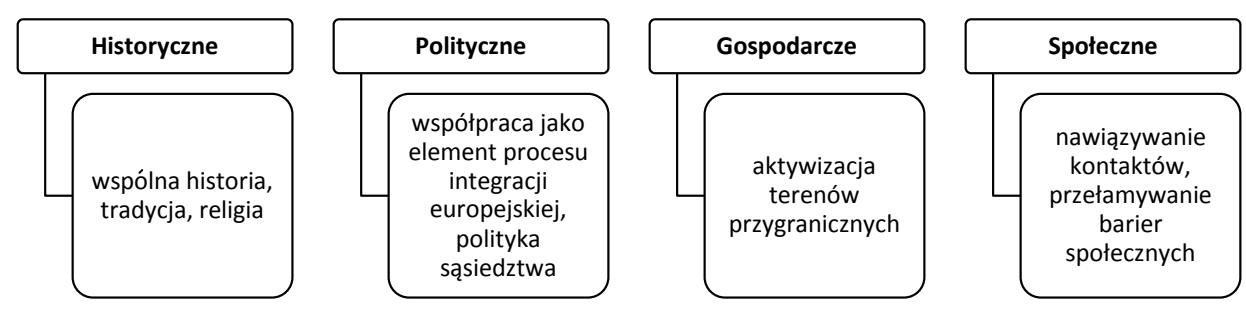

Schemat 3.2. Główne przesłanki rozwoju współpracy transgranicznej w Europie

Źródło: B. Kawałko, Granica wschodnia jako czynnik ożywienia i rozwoju społeczno-ekonomicznego regionów przygranicznych. Synteza, 2008, s. 625, http://www.polskawschodnia.2007-2013.gov.pl/ analizyraportypodsumowania/documents/kawalko.pdf [dostęp: 23.05.2014].

Współdziałanie „ponad granicami” w Europie ma wieloletnią i bogatą tradycję, jest nieodzownym czynnikiem determinującym stały i zrównoważony rozwój regionów. Kooperacja pomiędzy regionami przygranicznymi w głównej

4 Rada Europy, Europejska Konwencja Ramowa o współpracy transgranicznej między wspólnotami i władzami terytorialnymi - dokument Rady Europy podpisany 21 maja 1980 r. w Madrycie.

5 M. Obrębalski, Społeczno-ekonomiczna charakterystyka pogranicza Polski, „Wiadomości Statystyczne", nr 10/1999, s. 58.

6 Problemy polsko-ukraińskiej współpracy przygranicznej,,_Biuletyn PAN”, nr 9/1995, s. 51.

7 M. Fic, Elementy metodologii obszarów przygranicznych, "Wiadomości Statystyczne", nr 11/1996, s. 23.

8 B. Kawałko, Stymulowanie rozwoju w regionie transgranicznym, "Gospodarka Narodowa", nr 6/1997, s. 47-49. 
mierze oparta jest o wewnętrzny potencjał regionu, zasoby naturalne i ludz$k^{9}{ }^{9}$. Nawiązanie współpracy może prowadzić do wzrostu poziomu konkurencyjności regionów przygranicznych, poprzez ułatwienie im dostępu do rynków zagranicznych ${ }^{10}$.

Z ekonomicznego punktu widzenia współpraca transgraniczna umożliwia trwały i zrównoważony rozwój obszarów przygranicznych, określanych często mianem peryferyjnych lub zacofanych ${ }^{11}$. Jej przejawem jest podejmowanie szeregu działań wspierających rozwój małej i średniej przedsiębiorczości, inicjatyw związanych z ochroną środowiska naturalnego, wspieraniem handlu oraz przedsięwzięć kulturalnych. Socjologiczny aspekt współpracy transgranicznej przejawia się w tym, że bardzo często granice państw określane są mianem „blizn historii”, które dzielą ludność o podobnej charakterystyce społecznej i przywiązaniu do wspólnych wartości.

Współpraca „ponad granicami” stanowi dla społeczności regionalnych i lokalnych, a także dla całej Unii Europejskiej element współtworzący integrację gospodarczą i społeczną. Istotą współpracy transgranicznej jest tworzenie sieci powiązań na szczeblu regionalnym i lokalnym, dzięki którym tworzy się stała i skoordynowana współpraca gospodarcza i kulturalna ${ }^{12}$.

Współpraca transgraniczna ${ }^{13}$ dotyczy transgranicznych więzi i relacji pomiędzy władzami regionalnymi, jest zjawiskiem zróżnicowanym i złożonym, wpływającym na budowanie więzi i relacji międzynarodowych, stanowi składowy element wszystkich programów samorządowych gmin przygranicznych, jest formą uspołeczniania stosunków międzynarodowych. Pogłębianie zakresu współpracy „ponad granicami” i jej coraz szerszy zakres związane są z rosnącymi potrzebami społeczności regionalnych i lokalnych.

9 B. Kawałko, Granica wschodnia jako czynnik ożywienia i rozwoju społeczno-ekonomicznego regionów przygranicznych. Synteza, Ekspertyza dla Ministerstwa Rozwoju Regionalnego, Warszawa 2008, s. 623.

10 A. Mierosławska, Czynniki aktywizujące i hamujące rozwój współpracy transgranicznej, "Samorząd Terytorialny", nr 3/2004, s. 43.

11 K. Tomaszewski, Regiony w procesie integracji europejskiej, Oficyna Wolters Kluwer Polska, Kraków 2007, s. 113.

12 E. Szadkowska, Pojęcie współpracy transgranicznej, [w:] M. Perkowski, Współpraca transgraniczna. Aspekty prawno-ekonomicznego, Fundacja Prawo i Partnerstwo, Białystok 2010, s. $15-16$.

13 M. Greta, T. Kostrzewa-Zielińska, Od współpracy transgranicznej do euro regionalizacji i uruchamiania przedsiębiorczości lokalnej, „Ekonomia i Zarządzanie. Zeszyty Naukowe Politechniki Białostockiej", z. 12/2008, s. 66-67. 


\subsubsection{Geneza i podstawy prawne europejskiej współpracy transgranicznej}

Koncepcje współpracy regionalnych i lokalnych społeczności wykraczających poza granice jednego państwa narodziły się w Europie w latach 50. XX w. Rozwój i pogłębianie procesów integracyjnych w Europie przyczyniły się do wzrostu znaczenia regionów transgranicznych. W 1971 r. utworzono Stowarzyszenie Europejskich Regionów Granicznych (SERG) ${ }^{14}$, a w 1985 r. powstała Rada Regionów Europejskich, która w 1987 r. przekształcona została w Zgromadzenie Regionów Europy ${ }^{15}$. Kolejnym etapem w kształtowaniu europejskiej współpracy transgranicznej było powołanie w 1994 r. Komitetu Regionów, w skład którego wchodzą przedstawiciele władz lokalnych i regionalnych ${ }^{16}$. Komitet Regionów ma za zadanie dbać o interesy społeczności lokalnych i regionalnych. Komisja i Rada zobowiązane są do zasięgania opinii Komitetu przed zatwierdzeniem propozycji legislacyjnych dotyczących regionów ${ }^{17}$.

Począwszy od końca lat 80. XX w., władze Wspólnot Europejskich podejmują szereg działań mających na celu promocję i rozwój regionów. Ogólny kierunek został zachowany zapisami Traktatu z Lizbony (01.12.2009). Jego celem jest uczynienie z Unii Europejskiej najbardziej konkurencyjnej gospodarki świata. Uregulowania zawarte w Traktacie podkreślają konieczność poprawy pozycji i znaczenia regionów oraz uwzględnienia potrzeb społeczności lokalnych ${ }^{18}$.

Dynamiczny rozwój współpracy transgranicznej można było zaobserwować w Europie na przełomie lat 60. i 70. Wówczas o kształcie i formie tej współpracy decydowały umowy bilateralne zawierane pomiędzy zainteresowanymi krajami ${ }^{19}$. W pierwszym okresie istnienia Wspólnot Europejskich wyraźnym orędownikiem współpracy regionów przygranicznych została Rada Europy ${ }^{20}$.

14 K. Gawlikowska-Hueckel, A. Zielińska-Głębocka, Integracja europejska. Od jednolitego rynku do unii walutowej, Wydawnictwo C.H. Beck, Warszawa 2004, s. 54-65.

15 M. Lechwar, Instytucjonalne podstawy europejskiej współpracy transgranicznej, Rzeszów 2008, s. 24.

16 A. Palej, Wzrost znaczenia regionów i ich roli w Unii Europejskiej na przykładzie najnowszych propozycji i postulatów w wymiarze politycznym i ekonomicznym, Konferencja „20 lat demokracji, 5 lat członkostwa. Jaka Polska w jakiej Unii Europejskiej?" 24-25 listopada 2009 r., Kraków-Przegorzały, s. 5.

17 A. Wlaź, Instytucje Unii Europejskiej, Ministerstwo Spraw Zagranicznych, Warszawa 2010, s. 30 .

18 M. Perkowski, Prawo zarządzania projektami finansowymi z funduszy europejskich, Wydawnictwo Wolters Kluwer, Warszawa 2008, s. 36.

19 E. Kulesza, Współpraca transgraniczna jako czynnik rozwoju lokalnego na przykładzie gmin polskiego pogranicza z Rosja, Toruń 2003, s. 39.

20 M. Greta, Euroregiony a integracja europejska. Wnioski dla Polski, Wydawnictwo Uniwersytetu Łódzkiego, Łódź 2003, s. 76. 
Przełomowym momentem w realizacji współpracy transgranicznej w Europie było zalecenie 784 Zgromadzenia Parlamentarnego z 28 czerwca 1975 r. Zwrócono w nim uwagę na konieczność stworzenia norm prawnych i podpisania konwencji na temat współpracy transgranicznej ${ }^{21}$. Rezultatem podejmowanych działań było podpisanie w 1980 r. Europejskiej Konwencji Ramowej o Wspótpracy Transgranicznej między Wspólnotami i Władzami Terytorialnymi (Konwencja Madrycka), której cel określony w Preambule wskazuje na konieczność wspierania współpracy transgranicznej i rozwoju społeczno-gospodarczego regionów przygranicznych ${ }^{22}$. W konwencji tej również zawarto definicję współpracy transgranicznej obowiązującą w Unii Europejskiej ${ }^{23}$, którą określono jako: „każde wspólne podjęte działanie mające na celu umocnienie i dalszy rozwój sąsiedzkich kontaktów między wspólnotami i władzami terytorialnymi dwóch lub większej liczby umawiających się stron"24. Postanowienia zawarte w Konwencji Madryckiej pozwalają na wykreowanie pewnych modeli umów międzypaństwowych, wśród których można wyodrębnić:

- model prostej umowy pomiędzy państwami członkowskimi, którego celem jest promowanie i zachęcanie do nawiązywania współpracy transgranicznej,

- umowa typu gentleman agreement, która nie wymusza zobowiązań prawnych i jest realizowana w drodze konsultacji i porozumień,

- model traktatu zobowiązującego władze regionalne lub lokalne do zawierania umów w oparciu o ustawodawstwo publiczne lub prywatne,

- model traktatu dający władzom regionalnym instytucjonalizację współpracy poprzez zawieranie stowarzyszeń i związków władz lokalnych ${ }^{25}$.

Istotny wkład w rozwój współpracy transgranicznej wniosła Europejska Karta Samorzadu Terytorialnego podpisana 15 października 1985 r. przez Komitet Ministrów Rady Europy ${ }^{26}$. Najważniejsze dla realizacji współpracy transgranicznej było uwzględnienie idei autonomii władzy lokalnej w międzynarodowych uregu-

21 R. Radek, Znaczenie współpracy transgranicznej w rozwoju społeczności lokalnych i regionalnych, Katowice 2007, s. 109.

22 R. Kusiak-Winter, Współpraca transgraniczna gmin Polski i Niemiec - studium administracyjnoprawne „,Prace Naukowe Wydziału Prawa, Administracji i Ekonomii Uniwersytetu Wrocławskiego", nr 11/2011, s. 67.

23 E. Szadkowska, Prawny wymiar współpracy transgranicznej, [w:] M. Perkowski, Współpraca transgraniczna. Aspekty prawno-ekonomiczne, Fundacja Prawo i Partnerstwo, Białystok 2010, s. 26.

24 E. Wilde de, Ten years of European outline convention on transfrontier co-operation - Results and new prospects, Council of Europe, 5th European Conference of Frontier Regions Rovaniemi/Finland, 18-21 June 1991, s. 224.

25 S. Ercman, Das Europäische Rahmenübereinkommen über die grenzüberschreitende Zusammenarbeit zwischen Gebietskörperschaften, [w:] M. Bothe, M. Prieur, G. Ress (red.), Rechtsfragen grenzüberschreitender Umweltbelastungen, Fachtagung/Saarbrucken, Berlin 1984, s. 252

26 Europejska Karta Samorzq̨u Lokalnego, Dz.U. z 1994 r., nr 124, poz. 607. 
lowaniach prawnych, a także wspieranie idei samorządności i rozwoju społeczności lokalnych ${ }^{27}$. Dokument zawiera nadrzędne zasady funkcjonowania samorządu terytorialnego w Unii Europejskiej i zapewnia możliwość zawierania przez gminy współpracy z zagranicznymi partnerami ${ }^{28}$. Konwencja Madrycka stanowi lex specialis w zakresie współpracy transgranicznej w porównaniu do Europejskiej Karty Samorzadu Terytorialnego ${ }^{29}$.

Kolejnym ważnym dokumentem dotyczącym współpracy transgranicznej jest opracowana przez Stowarzyszenie Europejskich Regionów Granicznych Europejska Karta Regionów Granicznych i Transgranicznych (19 listopada 1981 r.) ${ }^{30}$. Przedstawia ona zadania mające wpływ na rozwój terenów transgranicznych: niwelowanie negatywnego wpływu granic państwowych na rozwój społeczności przygranicznych, wzmacnianie możliwości i warunków społeczno-gospodarczych, ujednolicenie planów przestrzennych w Europie, likwidacja barier i przeszkód wynikających $z$ uwarunkowań infrastrukturalnych i gospodarczych ${ }^{31}$. Uregulowania prawne dotyczące ochrony środowiska naturalnego nakładają na państwa obowiązek nawiązywania współpracy transgranicznej ${ }^{32}$. Biorąc pod uwagę kwestie dotyczące polityki regionalnej, należy nadmienić, że kształt współpracy transgranicznej ewoluował wraz z rozwojem polityki spójności społeczno-gospodarczej ${ }^{33}$.

Współpraca transgraniczna w literaturze przedmiotu bardzo często określana jest mianem polityki sąsiedztwa co najmniej dwóch państw oddzielonych wspólną granicą ${ }^{34}$. Podmiotami realizującymi współpracę transgraniczną są zarówno jednostki terytorialne, jak i inne podmioty gospodarcze i społeczne szczebla regionalnego lub lokalnego ${ }^{35}$. Umocowania prawne niezwykle ważne dla realizacji współpracy transgranicznej zapewniają również regulacje zawarte w ustawodaw-

27 M. Lis, Regiony jako trzeci poziom współpracy europejskiej, [w:] M. Maciejewski (red.), Społeczeństwo w przełomie. Polska, Niemcy i Unia Europejska, Wrocław 1999, s. 300.

28 I. Lipowicz, Europejski standard samorzq̨du terytorialnego a ustawodawstwo polskie, "Samorząd Terytorialny", nr 11-12/1991, s. 75.

29 Council of Europe, Explanatory report on the European Charter of Local Self-Government, Strasburg 1984, s. 18.

30 Europejska Karta Regionów Granicznych i Transgranicznych uchwalona w EUREGIO na pograniczu Holandii i Niemiec, 20 listopada 1981 r.

31 Z. Matusiewicz, Lokalny wymiar integracji europejskiej, [w:] M. Barański, M. Stolarczyk (red.), Władze lokalne i regionalne w warunkach globalizacji, Wydawnictwo Uniwersytetu Śląskiego, Katowice 2003, s. 368.

32 R. Kusiak-Winter, op. cit., s. 85-86.

33 K. Gawlikowska-Hueckel, A. Zielińska-Głębocka, Integracja europejska. Od jednolitego rynku do unii walutowej, Wydawnictwo C.H. Beck, Warszawa 2004, s. 34.

34 S. Dołzbłasz, A. Raczyk, Współpraca transgraniczna w Polsce po akcesji do UE, Warszawa 2010, s. 14.

35 E. Bruszewska, Państwo we współpracy transgranicznej, [w:] M. Perkowski (red.), Współpraca transgraniczna. Aspekty prawno-ekonomiczne, Fundacja Prawo i Partnerstwo, Białystok 2010, s. 32. 
stwie wewnętrznym poszczególnych państw. Szczegółowo wyodrębnione zasady, cele i formy współpracy transgranicznej są rezultatem umów bilateralnych podpisywanych pomiędzy krajami członkowskimi ${ }^{36}$.

\subsubsection{Formy współpracy transgranicznej}

Współpraca transgraniczna realizowana jest w różnych formach: w komisjach rządowych, komisjach planowania przestrzennego i w tzw. zinstytucjonalizowanych formach współpracy transgranicznej określanych mianem euroregionów ${ }^{37}$. Zgodnie z unormowaniami legislacyjnymi można wyodrębnić dwie główne formy współpracy transgranicznej:

- rządową, która polega na udziale terenowej administracji rządowej w kreowaniu i tworzeniu ram dla współpracy transgranicznej,

- rządowo-samorządową, która związana jest głównie z działaniami podejmowanymi przez jednostki samorządu terytorialnego ${ }^{38}$.

Wśród licznych form współpracy transgranicznej istotną rolę odgrywają porozumienia i umowy zawierane pomiędzy państwami na podstawie przepisów obowiązującego prawa wewnętrznego państw. Dotyczą one przede wszystkim współpracy gospodarczej, w dziedzinie kultury, polepszania infrastruktury, zagospodarowania przestrzennego, działań w zakresie ochrony środowiska. Obok porozumień między państwami we współpracy przygranicznej są również porozumienia na niższych szczeblach, w tym: dwustronne pomiędzy województwami i obwodami oraz porozumienia samorządów i gmin ${ }^{39}$.

Do form współpracy transgranicznej należy zaliczyć euroregiony oraz projekt europejski, który daje możliwość realizacji przedsięwzięć i projektów współfinansowanych przez Unię Europejską. Zgodnie z definicją Project Management Institute jest to „ograniczone w czasie przedsięwzięcie podejmowane w celu wytworzenia unikatowego wyrobu, dostarczenia unikatowej usługi lub uzyskania unikatowego rezultatu". W przytoczone wyżej ujęcie definicyjnie doskonale wpisuje się Komisja Europejska, która uznaje, że jest to „szereg działań o określonych ce-

36 Współpraca transgraniczna na przykładzie Euroregionu Karpaty, Pojęcie współpracy transgranicznej $i$ euroregionu, http://lukdan.vxm.pl/karpacki/podstawy_prawne.html\#umowy [dostęp 04.04.2013].

37 Biuro Studiów i Analiz Kancelarii Senatu, Dokumenty europejskie. Współpraca transgraniczna i regionalna, Warszawa 1995, s. 113.

38 B. Kawałko, Granica wschodnia jako..., s. 638; M. Proniewski, Wpływ granicy i współpracy transgranicznej na rozwój regionalny i lokalny regionu północno-wschodniego, [w:] A. Mync, R. Szul (red.), Rola granicy i współpracy transgranicznej w rozwoju regionalnym i lokalnym, Europejski Instytut Rozwoju Regionalnego, Warszawa 1999, s. 112-115.

39 B. Kawałko, Wybrane problemy polsko-ukraińskiej współpracy transgranicznej, „Barometr Regionalny. Analizy i prognozy", nr 2(24)/2011, s. 45. 
lach zmierzających do osiągnięcia wytyczonego wyniku w ograniczonych ramach czasowych" ${ }^{\text {"40 }}$. Wśród partnerów projektu europejskiego można wymienić jednostki samorządu terytorialnego, uczelnie wyższe, izby gospodarcze i handlowe, instytucje kultury, kościoły, euroregiony.

\subsection{Euroregion, euroregionalizacja - ujęcie teoretyczne}

Koncepcja tworzenia euroregionów narodziła się w Europie w następstwie procesów społecznych, gospodarczych i politycznych zachodzących po II wojnie światowej. Jej genezy należy upatrywać w związku z pojawieniem się trzech wspólnot: Europejskiej Wspólnoty Węgla i Stali, Europejskiej Wspólnoty Energii Atomowej oraz Europejskiej Wspólnoty Gospodarczej. Euroregiony stały się pomostami pomiędzy obszarami położonymi po dwóch stronach granicy, ułatwiając swobodę przepływu usług, kapitału i ludzi oraz zapewniając dostęp do lokalnych rynków zbytu. Pierwszy euroregion powstał na granicy niemiecko-holenderskiej w $1958 \mathrm{r}$. Od jego nazwy „Euregio” wprowadzono termin euroregion, który określa zinstytucjonalizowaną formę współpracy regionów przygranicznych ${ }^{41}$.

\subsubsection{Euroregion - definicja, cele, struktura organizacyjna}

Punktem wyjścia dla tworzenia euroregionów była współpraca transgraniczna, a euroregion można rozumieć jako: „region szczególny, transgraniczny, łączący współpracą regiony co najmniej dwóch sąsiadujących ze sobą państw, w których ta współpraca została zinstytucjonalizowana"42. Przewodnik współpracy transgranicznej definiuje euroregion jako: „formalną strukturę współpracy transgranicznej, skupiającą przedstawicieli szczebla regionalnego, a także w uzasadnionych przypadkach partnerów gospodarczych i społecznych. Ma zwykle typową strukturę organizacyjną, składającą się z wybieralnej rady, zarządu, tematycznych grup

40 A. Jabłońska, W. Hryniewiecka, Projekt Europejski jako forma współpracy transgranicznej, [w:] M. Perkowski (red.), Współpraca transgraniczna. Aspekty prawno-ekonomiczne, Fundacja Prawo i Partnerstwo, Białystok 2010, s. 91.

41 M. Greta, T. Kostrzewa-Zielińska, Od współpracy transgranicznej do euro regionalizacji i uruchamiania przedsiębiorczości lokalnej, „Ekonomia i Zarządzanie. Zeszyty Naukowe Politechniki Białostockiej", z. 12/2008, s. 65-66.

42 Ibidem, s. 68. 
roboczych oraz sekretariatu" ${ }^{43}$. Inna definicja euroregionu odnosi się do lokalizacji geograficznej i uznaje, że jest nim pewien „obszar geograficzny, obejmujący przygraniczne części dwu lub więcej państw, które chcą ze sobą współpracować i koordynować działania społeczności lokalnych w różnych dziedzinach" ${ }^{34}$. Zakres współpracy euroregionalnej jest szeroki i może obejmować wiele dziedzin życia gospodarczego, społecznego i kulturalnego. Definicja administracyjna wskazuje, że euroregion to „ponadgraniczne zjednoczenie związków administracyjnych w celu poprawy stosunków we wszystkich płaszczyznach życia społeczno-gospodarczego członków tego zjednoczenia" ${ }^{35}$. Euroregiony realizują zarówno zadania dotyczące bieżących problemów, jak i prowadzą działalność strategiczną zmierzającą do scalania ugrupowania integracyjnego poprzez aktywizację terenów przygranicznych państw członkowskich ${ }^{46}$. W literaturze przedmiotu mianem euroregionu określa się również „grupę jednostek municypalnych należących do państw położonych po różnych stronach granicy, posiadających wspólną strukturę administracyjną" ${ }^{37}$.

Z kolei Różycki definiuje euroregion jako: „pewną przestrzeń, w której krajobraz i mieszkańcy mają mnóstwo cech wspólnych, a zarazem odróżniają się od innych regionów; jest to również wielostronna, ponadgraniczna wspólnota komunalna, utworzona na obszarach części państw wchodzących w skład danego państwa"48.

Euroregiony mogą być tworzone $z$ inicjatywy gminy (euroregiony samorządowe) bądź przez przedstawicielstwa władzy rządowej na szczeblu wojewódzkim. Euroregion można scharakteryzować jako:

- formalny związek, działający w oparciu o instytucje i organy powołane przez władze państwowe lub regionalne,

- nieformalny związek, oparty o współpracę pomiędzy powołanymi stowarzyszeniami, dążącymi do zwiększania współpracy pomiędzy regionami położonymi wzdłuż granic państwowych,

- porozumienie co najmniej dwóch regionów oddzielonych granicą państwową należącą do co najmniej dwóch państw, mających zinstytucjonalizowany charakter,

43 Stowarzyszenie Europejskich Regionów Granicznych, Praktyczny przewodnik współpracy transgranicznej, Warszawa 1997, s. 24.

44 M. Golka, Pogranicza - transgraniczność - transkulturowość, [w:] L. Gołdyka (red.), Transgraniczność w perspektywie socjologicznej - kontynuacje, Zielona Góra 1999, s. 13-15.

45 G. Michałowska (red.), Mały słownik stosunków międzynarodowych, Warszawa 1996, s. 37.

46 M. Greta, K. Lewandowski, Euroregion Bałtyk wobec wyzwań aktywujących pogranicze , „Ostrołęckie Towarzystwo Naukowe im. Adama Chętnika. Zeszyty Naukowe", nr 20/2006, s. 145.

47 K. Sodu, Foreign Direct Investment for Development. Maximizing Benefits Minimizing Costs, OECD Report 2002, s. 37.

48 S. Różycki, Idea euroregionalizacji i jej ocena na przykładzie badań ankietowych w euroregionie Nysa, Wydawnictwo Akademii Ekonomicznej, Liberez 1995, s. 140. 
- stowarzyszenie przygranicznych regionów administracyjnych co najmniej dwóch państw uznających granicę państwową,

- organizację ponad granicami powołaną w celu rozwiązywania lokalnych problemów gospodarczych, społecznych, kulturowych, budowania więzi społecznych i relacji gospodarczych ${ }^{49}$.

Instytucje współpracy powoływane są na podstawie wewnętrznych uregulowań prawnych, a współdziałanie pomiędzy nimi odbywa się w oparciu o umowy partnerskie przekraczające granice państwowe ${ }^{50}$. Powołanie organizacji euroregionalnej wymaga akceptacji ze strony Unii Europejskiej, która poprzez narzędzia polityki regionalnej zapewnia określoną pomoc finansową. W słowie euroregion cząstka „euro” oznacza określoną lokalizację przestrzenną i integrację w ramach UE, natomiast druga jego część „region” dotyczy określonego terytorium geograficznego ${ }^{51}$.

Czynnikiem odróżniającym zwykłą współpracę transgraniczną od euroregionu jest pojawienie się stałych i zinstytucjonalizowanych form kooperacji w formie stowarzyszeń, rad, sekretariatów czy grup roboczych ${ }^{52}$. Głównym celem euroregionów jest „współpraca gospodarcza, rozwój połączeń komunikacyjnych, ochrona środowiska oraz działalność kulturalno-edukacyjna i turystyka" ${ }^{33}$. Swoje działania koncentrują na podnoszeniu poziomu życia mieszkańców regionów peryferyjnych i wzroście konkurencyjności regionów przygranicznych, wymianie doświadczeń i informacji, rozwoju gospodarki i infrastruktury drogowej, kolejowej oraz technicznej, usprawnieniu ruchu granicznego, budowaniu relacji pomiędzy podmiotami gospodarczymi, dbałości o środowisko naturalne, zapobieganiu klęskom żywiołowym, nawiązywaniu relacji pomiędzy szkołami i instytucjami publicznymi ${ }^{54}$.

49 G. Ślusarz, Czynniki rozwoju społeczno-gospodarczego - aspekty teoretyczne, [w:] A. Czudec, G. Ślusarz (red.), Regionalne uwarunkowania rozwoju wiejskich obszarów przygranicznych Polski i Ukrainy, Rzeszów 2003, s. 21; M. Greta, T. Kostrzewa-Zielińska, Od współpracy transgranicznej do euroregionalizacji i uruchamiania przedsiębiorczości lokalnej, „Zeszyty Naukowe Politechniki Białostockiej. Ekonomia i Zarządzanie", z. 12/2008, s. 69; W. Malendowski, M. Ratajczak, Euroregiony. Pierwszy krok do integracji europejskiej, Dom Wydawniczy Elipsa, Wrocław 1998, s. 90.

50 A. Warych-Juras, Euroregiony jako nowa forma współpracy europejskiej, „Informator Polskiego Towarzystwa Geograficznego Oddział w Krakowie", t. 1/2003, s. 178-179.

51 W. Jastrzębska, Rola euroregionów i współpracy transgranicznej w procesie integracji europejskiej, Wydawnictwo Uniwersytetu Rzeszowskiego, Rzeszów 2008, s. 97.

52 E. Małecka (red.), Euroregiony na granicach Polski 2003, GUS, Wrocław 2004, s. 16.

53 Z. Czachór, Słowniczek europejski, Przedstawicielstwo Komisji Europejskiej w Polsce, Warszawa 1996, s. 6.

54 W. Malendowski, M. Ratajczak, Euroregiony - pierwszy krok do integracji europejskiej, Wydawnictwo Alta 2, Wrocław 1998, s. 11-18; W. Malendowski, M. Szczepaniak, Rola euroregionów w procesie integracji europejskiej, [w:] W. Malendowski, M. Szczepaniak (red.), Euroregiony - mosty bez granic, Wydawnictwo Dom Wydawniczy Elipsa, Warszawa 2000, s. 8. 
W euroregionach prowadzona jest polityka regionalna określana mianem euroregionalizacji. Polega ona na wytyczaniu i realizowaniu określonych zamierzeń i celów ukierunkowanych na niwelowanie różnic w rozwoju peryferyjnych obszarów transgranicznych w Unii Europejskiej. Euroregionalizacja ma służyć wzmacnianiu kohezji społeczno-gospodarczej w regionach peryferyjnych. Zdaniem M. Grety euroregionalizacja to: „polityka regionalna prowadzona w euroregionach polegająca na tworzeniu euroregionów i osiąganiu celów związanych $\mathrm{z}$ niwelowaniem dysproporcji regionalnych $\mathrm{w}$ regionach transgranicznych" ${ }^{55}$.

Euroregiony wykształciły własne struktury organizacyjne, których charakter uzależniony jest od celów, metod i zakresu współpracy. Dokonując analizy porównawczej poszczególnych euroregionalnych struktur organizacyjnych $\mathrm{w}$ różnych częściach Starego Kontynentu, można zauważyć, że bardzo często tworzą je organy o podobnym charakterze i zbliżonym zakresie działalności. Mogą się one natomiast różnić liczbą członków tworzących dany organ ${ }^{56}$. Zgodnie z postanowieniami Europejskiej Konwencji Ramowej o współpracy przygranicznej między Wspólnotami i władzami terytorialnymi euroregiony posiadają prawo do dowolnej, wybranej przez nie formy współpracy, począwszy od spontanicznych, doraźnych spotkań, po zorganizowane grupy kontaktowe. Wzorcowy euroregion posiada następujące organy:

- zgromadzenie - organ o charakterze parlamentarnym, posiadający największy zakres kompetencji, jego członkowie pochodzą z wyboru;

- zarząd (prezydium) - kieruje działalnością euroregionu, reprezentuje go na zewnątrz, zarządza majątkiem, podejmuje działania w oparciu o przepisy prawa i regulamin wprowadzony na zebraniu członków ${ }^{57}$; określa kierunki i cele działania euroregionu, uchwala statut euroregionu i plany finansowe ${ }^{58}$. Prezydium tworzą wybrani przedstawiciele zarządu;

- grupy robocze - stanowiące swoiste forum wymiany doświadczeń, poglądów w celu określania i realizacji wyznaczonych celów;

- sekretariat - odpowiada za bieżącą obsługę organów euroregionów oraz przygotowuje i organizuje ich posiedzenia ${ }^{59}$.

55 M. Greta, Euroregionalizacja i jej wpływ na lokalny rynek pracy, [w:] D. Kopycińska (red.), Działania ekonomiczne podmiotów rynkowych, Katedra Mikroekonomii Uniwersytetu Szczecińskiego, Szczecin 2007. s. 188.

56 Analiza benchmarking Euroregionu Neisse-Nisa-Nysa oraz pozostałych euroregionów $w R C$ ze szczególnym uwzględnieniem granicy czesko-polskiej, http://www.ern.cz/analyza/ern_cz/pl/ index.php?D=7 [dostęp 17.02.2014].

57 Stowarzyszenie Euroregionu Karpaty, http://www.karpacki.pl/euroregion-fundusze_unijne -zarzad-39.html [dostęp 17.02.2014].

58 Umowa o współpracy pod nazwa euroregion Silesia zawarta w dniu 20 września 1998 r. w Opawie, http://www.euroregion-silesia.eu [dostęp 17.02.2014].

59 Urząd Komitetu Integracji Europejskiej, http://archiwum-ukie.polskawue.gov.pl/HLP/files. nsf/0/81B767C7051F6C90C1256E7B004840F6/\$file/EUROREGI.PDFs.2 [dostęp 12.07.2014]. 
Jednostki współtworzące euroregion posiadają odrębność prawną i są tworzone w oparciu o przepisy prawa wewnętrznego. Dzięki umocowaniu prawnemu mają możliwość zawierania porozumienia o współpracy i powołania wspólnych organów. Decyzje i ustalenia podejmowane przez organy euroregionów są wiążące jedynie dla nich, nie obejmują jednak mieszkańców zamieszkałych w danym euroregionie. Dopiero jednostki samorządowe poprzez podjęcie odpowiednich decyzji mogą nadać tym ustaleniom moc prawa powszechnie obowiązującego w danych regionach, pod warunkiem, że władza centralna nadała im takie kompetencje. Co do zasady zakres działań euroregionów i realizacja zadań ogranicza się wyłącznie do celów, które leżą w kompetencji danego euroregionu.

Euroregiony funkcjonują w oparciu o swoje statuty, które określają strony umowy euroregionalnej, prawa i obowiązki, nadrzędne zasady funkcjonowania euroregionów, skład ich organów czy sposoby finansowania współpracy ${ }^{60}$.

Euroregionalizacja na trwałe zapisała się na kartach historii integracji europejskiej, a jej rezultatem jest powstanie dziesiątków euroregionów zarówno na wewnętrznych granicach Unii Europejskiej, jak i na jej granicach zewnętrznych. Stanowią one nieodłączny element integracji w Unii Europejskiej. Euroregionalizacja przyczyniła się do wykreowania „społeczeństw euroregionalnych”, które są świadome swojej roli w kreowaniu wzrostu gospodarczego i rozwoju społecznego.

\subsubsection{Uwarunkowania rozwoju euroregionów}

Regiony przygraniczne charakteryzują się niższym poziomem życia obywateli i mniejszym tempem wzrostu gospodarczego względem obszarów centralnych. Euroregiony tworzone są, aby niwelować niekorzystne uwarunkowania położenia geograficznego i walczyć z niedogodnościami, takimi jak: peryferyjne położenie, niższy poziom rozwoju infrastruktury drogowo-kolejowej, słabszy poziom dostępu usług dla przedsiębiorców i ludności, odmienne systemy prawne i administracyjne dwóch sąsiadujących państw, utrudniony dostęp do centrów handlowych ${ }^{61}$.

Założeniem jest, aby euroregiony umożliwiały osiąganie korzyści w wyniku działań podejmowanych ponad granicami państwowymi ${ }^{62}$. Pierwsze euroregio-

60 Załącznik nr 1 do uchwały nr 2/XXI/2003 Konferencji Krajowej Stowarzyszenia Gmin Polskich Euroregionu Nysa z dnia 20 października 2003 r. w sprawie zmiany statutu; Statut Stowarzyszenia Gmin Polskich Euroregionu Nysa; A. Warych-Juras, Euroregiony jako nowa forma współpracy europejskiej, „Informator Polskiego Towarzystwa Geograficznego Oddział w Krakowie", t. 1/2003, s. 183.

61 I. Pietrzyk, Polityka regionalna Unii Europejskiej i regiony w państwach członkowskich, Wydawnictwo Naukowe PWN, Warszawa 2002, s. 299.

62 W. Malendowski, M. Ratajczak, Euroregiony - pierwszy krok do integracji europejskiej, Wydawnictwo Alta 2, Wrocław 1998, s. 8; W. Malendowski, M. Szczepaniak, op. cit., s. 10-18. 
ny na zachodzie Europy powstawały głównie w celu łagodzenia lokalnych konfliktów, potem ich misją stało się zmniejszanie dysproporcji w rozwoju terenów peryferyjnych $^{63}$. U podstaw zacieśniania współpracy transgranicznej $\mathrm{w}$ formie euroregionów leżą przesłanki gospodarcze, historyczne, polityczne, społeczne i kulturowe ${ }^{64}$.

Euroregiony w Europie Zachodniej współtworzyły obraz integrującego się kontynentu europejskiego i niewątpliwie przyczyniły się do realizacji idei zjednoczeniowych ${ }^{65}$. Ich funkcjonowanie można rozpatrywać na różnych płaszczyznach: prawnej, politycznej, historycznej, ekonomicznej. W aspekcie prawnym funkcjonowanie euroregionów oparte jest na przepisach wewnętrznych i uregulowaniach prawnych państw członkowskich. Euroregiony nie stanowią odrębnego regionu w danym państwie (nie są wyodrębnioną jednostką samorządową), a ich organy nie mają uprawnień do tworzenia prawa obowiązującego na ich obszarze. Na płaszczyźnie politycznej euroregiony działają zgodnie z linią polityki zagranicznej poszczególnych państw, są jej częścią składową. W ujęciu historycznym obszary euroregionów niejednokrotnie łączy wspólna, często skomplikowana historia ${ }^{66}$.

Rozwój euroregionów jest bardzo ściśle związany z rozwojem i wzrostem znaczenia współpracy transgranicznej, a także samej polityki regionalnej. Począwszy od drugiej połowy lat 80 . XX w., w Europie zachodzą dwa równolegle przebiegające procesy:

- integracyjne, mające na celu zmniejszanie znaczenia wewnętrznych granic Wspólnoty i wzmocnienie jej granic zewnętrznych,

- regionalizacyjne, mające na celu regionalizację (szczególnie dotyczącą nawiązywania kontaktów sąsiedzkich z regionami spoza ugrupowania) ${ }^{67}$.

Euroregiony „są punktami krystalizacji wzajemnych stosunków [...] Pozwalają unikać problemów, zanim się jeszcze pojawią i dostatecznie wcześnie rozpoznają ewentualne trudności i zapobiegają przeradzaniu się tychże w poważne problemy". Wydaje się, że powyższe stwierdzenie idealnie oddaje charakter i zadania euroregionów, które funkcjonują w myśl zasady: lepiej zapobiegać problemom niż później z nimi walczyć.

63 M. Greta, Euroregionalizacja i jej..., s. 188.

64 M. Mindur, Polityka współpracy transgranicznej na polskich pograniczach wschodnich, pótnocnych i południowych a przyspieszenie procesów integracyjnych Polski z państwami Unii Europejskiej, „Polityka Gospodarcza", nr 5-6/2001-2002, s. 201.

65 M. Greta, Euroregionalizacja i jej..., s. 189.

66 I. Źurba, Euroregion jako najbardziej zaawansowany organizacyjnie i funkcjonalnie poziom współpracy transgranicznej, „Nierówności Społeczne a Wzrost Gospodarczy”, nr 12/2008, s. $126-127$.

67 A. Warych-Juras, op. cit., s. 178. 


\subsubsection{Finansowanie działania euroregionów}

Euroregiony działają w oparciu o własne środki finansowe pochodzące w głównej mierze ze składek członkowskich oraz o fundusze przewidziane na realizację rozwoju współpracy transgranicznej w ramach unijnej polityki regionalnej ${ }^{68}$. Członkowie euroregionów mają obowiązek współpracy i finansowania działalności w uzgodnionej w Statucie wysokości oraz określonej formie ${ }^{69}$. Źródłami finansowania euroregionów są:

- składki członkowskie, część opłacana przez miasta i gminy zazwyczaj określana jest na rok i ustalona na poziomie kwoty przypadającej na jednego mieszkańca. Pozostali członkowie euroregionów opłacają składkę członkowską ustaloną na zasadach ryczałtowych. Statuty mogą również zawierać zapis zwalniający niektórych członków z opłacania składek;

- wpłaty od krajów lub miast, jest to specyficzna forma składek członkowskich, stanowiąca swoistą dotację na rzecz rozwoju obszarów peryferyjnych;

- przychody finansowe z własnej działalności gospodarczej, euroregiony mogą podejmować działalność ukierunkowaną na osiąganie zysków w celu późniejszej realizacji swoich priorytetowych zamierzeń;

- środki finansowe pochodzące z Unii Europejskiej wspierające rozwój i realizację współpracy transgranicznej, $\mathrm{w}$ tym $^{70}$ :

- środki finansowe pochodzące z Funduszu Małych Projektów za realizację obsługi administracyjnej (realizacja programów PHARE CBC, Interreg III),

- realizacja euroregionalnych projektów w ramach programów współpracy transgranicznej (w ramach PHARE CBC i Interreg III),

- realizacja projektów współpracy ponadnarodowej i międzyregionalnej w ramach Interreg B i C i projektów z funduszy strukturalnych,

- fundusze pieniężne przekazane $\mathrm{w}$ ramach jednorazowych projektów na konkretne przedsięwzięcia, konferencje, kampanie informacyjne,

- kredyty pomostowe, zaciągane na realizację priorytetowych celów rozwoju euroregionów ${ }^{71}$.

Środki finansowe Unii Europejskiej wspierające rozwój euroregionów są częścią trzeciego celu polityki spójności określanego mianem Europejskiej Współpra-

68 Euroregion Neisse-Nisa-Nysa, Analiza benchmarking Euroregionu Neisse-Nisa-Nysa oraz pozostałych euroregionów w RC ze szczególnym uwzględnieniem granicy czesko-polskiej, http://www.ern.cz/analyza/ern_cz/pl/index.php?D=10 [dostęp 22.06.2014].

69 Statut Zwiq̨zu Euroregion "Tatry", Rozdział VI Majątek Zwiq̨zku, § 24.

70 H. Rasz, Euroregiony na granicach Polski, Informacja nr 686, Biuro Studiów i Ekspertyz 1999, s. 13.

71 Euroregion Neisse-Nisa-Nysa, Analiza benchmarking Euroregionu Neisse-Nisa-Nysa oraz pozostałych euroregionów $w$ RCz ze szczególnym uwzględnieniem granicy czesko-polskiej. 
cy Terytorialnej ${ }^{72}$, będącej kontynuacją inicjatywy Interreg III $^{73}$. Fundusze z EWT służą: wspieraniu przedsiębiorstw (nacisk na rozwój MŚP), organizacji szkoleń, propagowaniu nauki języków obcych, zapobieganiu katastrofom przyrodniczym, ochronie zabytków i dóbr naturalnych, rozwojowi infrastruktury, polepszaniu stosunków dobrosąsiedzkich ${ }^{74}$.

Dużą rolę we współfinansowaniu współpracy transgranicznej odgrywa również Europejski Fundusz Rozwoju Regionalnego i powołane rozporządzeniem z 2006 r. Europejskie Ugrupowanie Współpracy Terytorialnej (EUWT) ${ }^{75}$. EUWT „umożliwia stowarzyszanie samorządów różnych państw członkowskich bez konieczności podpisywania uprzednio międzynarodowych umów, ratyfikowanych przez narodowe parlamenty"76. Ciekawymi programami uruchomionymi przez Unię Europejską na lata 2014-2020 są:

- Program Espon 2020 (48,6 mln euro, przy wsparciu z UE w wysokości 41,3 mln euro pochodzących z EFRR), którego celem jest wzmocnienie skuteczności europejskiej polityki spójności poprzez wsparcie współpracy w zakresie transferu badań, wiedzy i innowacji ukierunkowanego na rozwój europejskiego wymiaru terytorialnego,

- Interreg Europa (359 mln euro z EFRR), instytucje mogą podejmować współpracę nad wybranymi dziedzinami polityki regionalnej (w tym: rozwojem przedsiębiorczości, wsparciem dla klastrów itd.),

- Program Interact (39 mln euro z EFRR) ukierunkowany na poprawę zdolności instytucjonalnych oraz wydajności administracji publicznej (w tym zarządzanie i kontrola efektywności programów EWT),

- URBACT - Europejski Program Współpracy Terytorialnej dla Zrównoważonego Rozwoju Obszarów Miejskich (74,302 mln euro z EFRR).

Wszystkie wymienione inicjatywy i programy przewidziane na lata 2014-2020 wpisują się w koncepcję budowy innowacyjnej gospodarki opartej na wiedzy, a środki finansowe ukierunkowane są na wdrażanie innowacji, prowadzenie badań, szkolenia i edukację ${ }^{77}$.

72 J. Ładysz, Polityka strukturalna Polski i Unii Europejskiej, Wydawnictwo Naukowe PWN, Warszawa 2008, s. 150-151.

73 S. Naruszewicz, Polityka spójności Unii Europejskiej. Wybrane zagadnienia, Wydawnictwo Difin, Warszawa 2004, s. 318.

74 W. Kosiedowski, B. Słowińska, Położenie przygraniczne jako szansa rozwoju północno-wschodniej Polski w warunkach integracji europejskiej (w świetle badań ankietowych), [w:] Z. Strzelecki (red.), Samorząd terytorialny w Polsce. Szanse rozwoju regionalnego i lokalnego w warunkach Unii Europejskiej, Wydawnictwo SGH, Warszawa 2008, s. 363-366.

75 Committee of the Regions, 114th Meeting of the Committee of the Regions Bureau, Brussels, 28 January 2009 , s. 7-8.

76 B. Jurkowska, Unijne programy wsparcia współpracy transgranicznej w latach 2007-2013 w państwach członkowskich i sq̨siadujących z Unią Europejskq I,'Studia Lubuskie”,'t. VII/2011, s. 185, s. 201.

77 Serwis Programów Europejskiej Współpracy Teytorialnej, https://www.ewt.gov.pl/strony/ o-programach/przeczytaj-o-programach/urbact-iii/ [dostęp 23.05.2015]. 


\subsubsection{Instytucjonalne uwarunkowania rozwoju regionów}

Współpraca regionów przygranicznych jest jednym z priorytetów Unii Europejskiej. Niezwykle ważną rolę w jej rozwoju odgrywają unijne instytucje, w tym przede wszystkim Rada Europy, powołany w 1994 r. Komitet Regionów, pełniący funkcję doradczą dla Rady Unii Europejskiej, Parlamentu Europejskiego i Komisji Europejskiej oraz Stowarzyszenie Europejskich Regionów Granicznych (SERG) będące międzynarodową organizacją pozarządową, utworzoną przez regiony w celu zwiększenia ich roli we współpracy europejskiej ${ }^{78}$.

Rada Europy jest organizacją międzyrządową powstałą 5 maja 1949 r. Podstawowym celem Rady Europy jest realizacja działań w zakresie praw człowieka, demokracji, przestrzegania i tworzenia nowych standardów prawa w Europie ${ }^{79}$. Z punktu widzenia tematyki niniejszej monografii szczególnie ważne są kompetencje Rady Europy w zakresie: wsparcia samorządów lokalnych i regionalnych, rozwoju współpracy transgranicznej, analizy struktur administracyjnych władz lokalnych i regionalnych, wsparcia zróżnicowania kulturowego regionów $w^{80}$.

Komitet Regionów powołany został w 1994 r. na mocy Traktatu $z$ Maastricht. Jest to organ doradczy, który stanowi reprezentację poglądów i stanowisk społeczności lokalnych i regionalnych na temat ustawodawstwa Unii Europejskiej. Obowiązkiem Komisji i Rady Unii Europejskiej jest konsultowanie z Komitetem Regionów wszystkich inicjatyw i unormowań prawnych wpływających na rozwój społeczności lokalnych i regionalnych ${ }^{81}$. Komitet Regionów jest swoistą reprezentacją działającą w imieniu unijnych obywateli w sprawach związanych z kształtem i rozwojem polityki regionalnej. Pośredniczy w relacjach pomiędzy instytucjami Unii Europejskiej a regionami ${ }^{82}$. W Komitecie Regionów prowadzone są debaty i wydawane są zalecenia wpływające na kształt polityki regionalnej UE ${ }^{83}$. Zgodnie z zapisami deklaracji misji KR-u „Jesteśmy ambasadorami Europy w regionach, miastach i gminach, a także ich rzecznikami w europejskiej debacie[...]”. W Komitecie Regionów zasiadają przedstawiciele wszystkich państw członkowskich,

78 http://www.karpacki.pl/euroregion-karpacki/euroregiony-w-/ [dostęp 10.02.2014].

79 Stałe Przedstawicielstwo Rzeczpospolitej Polskiej przy Radzie Europy w Strasburgu, O Radzie Europy, http://www.strasburgre.msz.gov.pl/pl/o_re/o_radzie_europy_info/ [dostęp 14.02.2014].

80 M. Greta, Euroregiony polskie w procesie integracji europejskiej oraz w przezwyciężaniu peryferyjności i dysproporcji regionalnych, Wydawnictwo Uniwersytetu Łódzkiego, Łódź 2013, s. 64.

81 A. Stabińska, Historia i rola Komitetu Regionów, http://www.mazovia.pl/komitet-regionow/ historia-i-rola-komitetu-regionow [dostęp 10.01.2014].

82 Komitet Regionów (KR) - członkowie, https://polskawue.gov.pl/Komitet,Regionow,(KR),,czl onkowie,329.html [dostęp 10.01.2014].

83 A. Hadyńska, Komitet Regionów a wielopoziomowe sprawowanie rządów w Unii Europejskiej, http://euro.ue.poznan.pl/pl/konferencja/535/fb1324cf04d3d3eaec06a811fbe6903cfb 1324cf04d3d3eaec06a811fbe6903c [dostęp 12.02.2014]. 
obecnie liczy on 353 członków wybieranych na pięcioletnią kadencję. Skład Komitetu jest pochodną wyborów do władz samorządowych poszczególnych państw lub też mogą do niego wchodzić członkowie pełniący główne role we władzach regionalnych ${ }^{84}$. Zgodnie z ustaleniami z Lizbony Komitet Regionów na samym początku procesu legislacyjnego ma za zadanie pośredniczyć w konsultacjach pomiędzy społecznościami lokalnymi i regionalnymi a Komisją Europejską. Zadaniem Komitetu jest analizowanie wpływu unijnych aktów prawnych na rozwój lokalny i regionalny.

SERG odegrało istotną rolę w kreowaniu działań i inicjatyw ukierunkowanych na rozwój oraz reprezentowanie regionów granicznych i wymianę doświadczeń ${ }^{85}$. Główne zadania Stowarzyszenia Europejskich Regionów Granicznych oscylują wokół wsparcia dla regionów granicznych, niwelowania negatywnych aspektów funkcjonowania granic państwowych, $w$ tym przede wszystkim łagodzenie różnic w rozwoju społeczno-gospodarczym regionów peryferyjnych. Do Stowarzyszenia Europejskich Regionów Granicznych należą: regiony graniczne i transgraniczne Unii Europejskiej, są one pełnoprawnymi członkami z prawem głosu, regiony graniczne i transgraniczne państw posiadające przez okres dwóch lat status obserwatora oraz honorowi członkowie SERG - bez prawa głosu, a także osoby fizyczne, stowarzyszenia i instytucje współpracy transgranicznej - bez prawa głosu, pełniące funkcje doradcze ${ }^{86}$. Regiony wchodzące w skład SERG mają obowiązek promowania współpracy transgranicznej, informowania o bieżącej sytuacji w regionach oraz wpłacania składek członkowskich. Swoje zadania i cele SERG realizuje poprzez: wdrażanie programów i projektów, pozyskiwanie i zarządzanie funduszami, organizację konferencji związanych $\mathrm{z}$ regionami transgranicznymi, współpracę z Unią Europejską, przekazywanie informacji związanych z regionami granicznymi do wiadomości publicznej, rozwój działalności Centrum Europejskich Regionów Granicznych i Transgranicznych. Stowarzyszenie Europejskich Regionów Granicznych tworzą: Zgromadzenie Ogólne, Komitet Wykonawczy, Sekretarz Generalny ${ }^{87}$.

84 Komitet Regionów, http://europa.eu/about-eu/institutions-bodies/cor/index_pl.htm [dostęp 11.04.2014].

85 M. Lechwar, Instytucjonalne podstawy europejskiej współpracy transgranicznej, http://www. univ.rzeszow.pl/nauka/konferencje/rl_most/02-Lechwar.pdf [dostęp 15.03.2014].

86 Stowarzyszenie Europejskich Regionów Granicznych, http://archiwumukie.polskawue.gov. $\mathrm{pl} / \mathrm{www} /$ serce.nsf/0/257754E84270A9F3C1256E830060C6F0?Open\&RestrictToCategory= [dostęp 01.03.2012].

87 MonitorSamorządowy,Euroregiony, http://www.regioset.pl/monitor.php?lg=0\&art=7\&unit=5 [dostęp 15.04.2013]. 


\subsection{Współpraca transgraniczna jako wyznacznik rozwoju regionów}

Po zakończeniu II wojny światowej współpraca transgraniczna była jednym z warunków pokoju, a jej celem było dążenie do nawiązywania sąsiedzkich kontaktów po to, by niwelować pojawiające się antagonizmy pomiędzy społecznościami lokalnymi ${ }^{88}$. Obecnie jest ona ważnym czynnikiem kreującym korzyści gospodarcze i społeczne, a także umożliwiającym rozwój regionom peryferyjnym. Współpraca transgraniczna jest jednym $\mathrm{z}$ podstawowych warunków korzystania ze środków finansowych pochodzących z programów pomocowych służących usuwaniu dysproporcji w rozwoju poszczególnych regionów ${ }^{89}$.

Priorytetem współpracy transgranicznej jest stworzenie sieci powiązań pomiędzy regionami przygranicznymi państw i umożliwianie im współpracy gospodarczej, społecznej i rozwiązywania problemów ${ }^{90}$. Różnorodność form tej współpracy i jej szeroki aspekt podmiotowy i przedmiotowy stają się wyznacznikiem rozwoju terenów przygranicznych. Znamienne jest, że współpraca ta co do zasady odbywa się w oparciu o lokalne i regionalne zasoby oraz środki finansowe Unii Europejskiej.

Wzrost konkurencyjności powoduje, że regiony przygraniczne są często niejako zmuszane do podejmowania działań w interesie swoich obywateli. Ewolucji podlega również samo postrzeganie granicy państwowej. Następuje odejście od traktowania jej jako linii demarkacyjnej oddzielającej dwa często wrogo do siebie nastawione obszary. Współczesne granice państwowe stają się granicami administracyjnymi, a pomiędzy oddzielonymi przez nie obszarami odbywa się współpraca o szerokim zakresie. O jej kształcie decyduje wzrost znaczenia regionów w Unii Europejskiej ${ }^{91}$ oraz specjalnie jej dedykowane programy pomocy finansowej, zmierzające do rozbudowy infrastruktury transportowej i usuwania barier w przepływie towarów, usług i kapitału. Europejska Karta Regionów Granicznych i Transgranicznych uznaje, że podstawą aktywnej współpracy transgranicznej jest „rozwój infrastruktury regionów granicznych, usunięcie przeszkód w transgranicznym przepływie osób i towarów, wzrost poziomu przychodów i wysoko-

88 A. Żelazo, Pojęcie współpracy transgranicznej samorzq̨du terytorialnego, Polski Instytut Spraw Międzynarodowych, „Biuletyn”, nr 24(212)/2004, s. 1.

89 B. Jurkowska, Unijne programy wsparcia współpracy transgranicznej w latach 2007-2013 w państwach członkowskich i sq̨siadujących z Uniq Europejskq " "Studia Lubuskie", t. VII/2011, s. 185.

90 M. Greta, Euroregiony a integracja europejska. Wnioski dla Polski, Wydawnictwo Uniwersytetu Łódzkiego, Łódź 2003, s. 39.

91 A. Żelazo, Pojęcie współpracy transgranicznej..., s. 2-3. 
ści PKB brutto w stosunku do przeciętnej krajowej w państwach graniczących ze sobą" 92 .

Rada Europy, która odgrywa olbrzymią rolę w propagowaniu działań na rzecz regionów europejskich, wymienia trzy główne płaszczyzny współpracy transgranicznej:

- współpraca transgraniczna zapewnia lepszą jakość produktów i usług, prowadzi zatem do wzrostu efektywności władz samorządowych,

- zapewnienie autonomii i swobody w zakresie współpracy pomiędzy samorządami poszczególnych regionów położonych przy granicach różnych państw,

- określana mianem politycznej traktuje współpracę transgraniczną jako warunek zapewnienia pokoju i niwelowania wzajemnych antagonizmów.

Współpraca transgraniczna napotyka na szereg przeszkód wynikających z różnorodności regionów przygranicznych w Unii Europejskiej, a także znacznych dysproporcji w poziomie ich rozwoju ${ }^{93}$. Bariery w rozwoju poszczególnych regionów mogą być różne na granicach każdego z państw członkowskich, a czynniki negatywnie wpływające na rozwój współpracy w jednym kraju mogą być całkowicie nieistotne $\mathrm{w}$ drugim. Bariery mają charakter ekonomiczny, prawny lub społeczny ${ }^{94}$. Hamulcem ekonomicznym jest różne tempo wzrostu i poziomu życia obywateli mierzone przy pomocy wskaźnika PKB per capita ${ }^{95}$. Bardzo często regiony przygraniczne należą do obszarów peryferyjnych. W przeciwieństwie do regionów centralnych nie przyciągają zbyt wielu inwestorów zagranicznych ${ }^{96}$. Barierami natury prawnej są różnorodne wewnętrzne unormowania prawne dotyczące szeregu działań wpływających na współpracę transgraniczną, brak ujednolicenia zasad podatkowych, skomplikowane procedury dotyczące prowadzenia działalności gospodarczej ${ }^{97}$. Do przeszkód społecznych należy zaliczyć wzajemne antagonizmy będące wynikiem wspólnej, często tragicznej historii ${ }^{98}$.

92 M. Fic, S. Ogrodowicz, Badania społeczno-gospodarcze obszarów przygranicznych, „Wiadomości Statystyczne", nr 6/1996, s. 59.

93 S. Pisarenko, Bariery społeczno-gospodarcze ukraińsko-polskiej współpracy transgranicznej, [w:] J. Kitowski (red.), Czynniki i bariery regionalnej współpracy transgranicznej - próba syntezy, Wydział Ekonomiczny Filii Uniwersytetu Marii Curie-Skłodowskiej, Rzeszów 1998, s. 43.

94 A. Mierosławska, Czynniki aktywizujace i hamujące rozwój współpracy transgranicznej, "Samorząd Terytorialny", nr 3/2004, s. 47.

95 S. Ciok, Bariery i ograniczenia współpracy transgranicznej, [w:] J. Kitowski (red.), Czynniki bariery regionalnej współpracy transgranicznej - próba syntezy, Wydawnictwo UMCS, Lublin 1998, s. 62.

96 K. Krok, M. Smętkowski, Polsko-ukraińska współpraca transgraniczna, [w:] G. Gorzelak, K. Krok (red.), Nowe granice Unii Europejskiej - współpraca czy wykluczenie?, Wydawnictwo Naukowe Scholar, Warszawa 2006, s. 182-183.

97 B. Kawałko, Granica wschodnia..., s. 41.

98 E. Mikuła-Bączek, Czynniki ograniczające i aktywizujące współpracę transgraniczna Polski i Ukrainy, [w:] M. G. Woźniak (red.), Spójność społeczno-ekonomiczna a modernizacja regionów transgranicznych, Wydawnictwo Uniwersytetu Rzeszowskiego, Rzeszów 2008, s. 120. 


\subsection{Uwagi końcowe}

Współpraca transgraniczna pomiędzy regionami przygranicznymi w Unii Europejskiej jest swoistym elementem składowym działań podejmowanych w ramach integracji kontynentu europejskiego. Stanowi ważne ogniwo w realizacji unijnej polityki spójności społeczno-gospodarczej. Dotychczasowy dorobek prawny Unii Europejskiej wydaje się wystarczający, aby współpraca transgraniczna w oparciu o obowiązujące aktualnie przepisy prawa unijnego, międzynarodowego czy wewnętrznego mogła się trwale rozwijać. Euroregiony są specyficzną i charakterystyczną dla europejskiej współpracy transgranicznej zinstytucjonalizowaną formą kooperacji o szerokim zakresie problemowym. Współpraca transgraniczna $\mathrm{w}$ formie euroregionów niesie za sobą wiele korzyści prowadzących nie tylko do wzrostu gospodarczego i społecznego w regionach, lecz także do nawiązywania, a następnie zacieśniania relacji sąsiedzkich i pogłębiania procesów integracyjnych. 



\section{Rozdział 4 \\ Implementacja idei trwałego i zrównoważonego rozwoju w euroregionach}

\subsection{Uwagi wstępne}

Wdrażanie koncepcji zrównoważonego rozwoju powinno odbywać się poprzez współpracę pomiędzy władzami euroregionów oraz tworzenie specjalnych planów i strategii rozwoju długookresowego. Zasadność jej realizowania przez euroregiony związana jest $\mathrm{z}$ faktem, że kwestie ochrony środowiska i rozwoju gospodarczego mogą być najbardziej efektywnie rozwiązywane poprzez lokalne działania. Ten rozdział zawiera opis specyfiki funkcjonowania euroregionów w Europie Środkowo-Wschodniej oraz próbę uzasadnienia realizacji idei rozwoju zrównoważonego w euroregionach. Założono, że jednolite obszary przyrodnicze wymagają kompleksowej i jednolitej polityki środowiskowo-gospodarczej, a rozwiązywanie problemów związanych z gospodarką odpadami, ograniczeniem zanieczyszczeń czy aktywizacją gospodarczą ludności wymaga podejmowania działań w skali ich występowania, a zatem we współpracy pomiędzy gminami, powiatami i województwami.

\subsection{Geneza euroregionów}

Geneza tworzenia euroregionów w Unii Europejskiej sięga okresu po II wojnie światowej i wiąże się bezpośrednio z pojawiającymi się ideami jednoczenia kontynentu europejskiego. Rozwój euroregionów związany jest ze wzrostem znaczenia współpracy transgranicznej oraz pogłębianiem integracji na kontynencie, która rozwijała się w następujących etapach:

- w latach 40. XX w., tuż po II wojnie światowej głównym celem integracji $\mathrm{w}$ Europie było niwelowanie wzajemnych antagonizmów pomiędzy państwami, 
- zaczęto traktować zagadnienia gospodarcze jako pomost w jednoczeniu kontynentu,

- regiony zaczęto uznawać za wyodrębnione obszary geograficzne, o określonych wzajemnych relacjach społecznych, gospodarczych i kulturowych ${ }^{1}$.

Powstanie współpracy euroregionalnej przypada na lata 50. XX w. Jej prekursorami były związki z regionów pogranicza holendersko-niemieckiego i niemiecko-francuskiego. Za najstarsze euroregiony uznaje się Euroregion Euroregio i Ems-Dollar. Wieloletnią tradycję posiada również Euroregion Regio (pogranicze Niemiec, Francji i Szwajcarii). Dwa pierwsze euroregiony są znakomitym przykładem współpracy i pokonywania wzajemnych barier i animozji pomiędzy narodami. Euroregion Regio natomiast położony jest na granicy państw UE i Szwajcarii, państwa niebędącego członkiem Wspólnoty².

Interesującym przykładem przenikania wspólnej historii i tradycji jest Euroregion Saar-Lor-Lux położony na terytorium Niemiec, Francji, Belgii i Luksemburga. Obejmuje on terytoria państw, które stanowiły obszar Cesarstwa Rzymskiego Narodu Niemieckiego ${ }^{3}$. Podobnie Euroregion Arge Alp obejmujący obszar Tyrolu (Niemcy, Szwajcaria, Włochy), pasma górskiego, o które toczyły się spory pomiędzy Austrią i Włochami. Jeszcze przed II wojną światową Hitler i Mussolini podjęli decyzję, że region stanie się częścią Włoch. Podtrzymano ją również po II wojnie światowej, ale obszar zamieszkany był przez dużą grupę ludności posługującą się językiem niemieckim. W myśl zawartych porozumień zdecydowano się na zapewnienie pewnej autonomii regionowi, a współpraca euroregionalna odegrała znamienitą rolę $\mathrm{w}$ wykreowaniu porozumienia ${ }^{4}$. Regiony alpejskie stały się swoistymi prekursorami współpracy euroregionalnej na terenach górskich. Na bazie ich doświadczeń oparta została współpraca w Pirenejach, gdzie w 1983 r. powołano Wspólnotę Roboczą Regionów Pirenejskich obejmującą trzy regiony francuskie, cztery hiszpańskie (Katalonia, Aragonia, Nawarra i Kraj Basków) i Księstwo Andory. Podobne porozumienie oparte na rozwiązaniach alpejskich powstało pod nazwą Wspólnota Robocza Jury (francuski region Franche-Comté i kantony szwajcarskie Jury, Berna, Vaud i Neuchâtel).

Kwestie związane z rozwojem infrastruktury często decydowały o nawiązywaniu współpracy euroregionalnej - budowano nowe połączenia drogowe i kolejowe

1 R. Radek, Znaczenie współpracy transgranicznej w rozwoju społeczności lokalnych i regionalnych, Uniwersytet Śląski Wydział Nauk Społecznych Instytut Nauk Politycznych i Dziennikarstwa, Katowice 2007, s. 136.

2 Euroregion Karpacki, Geneza i rozwój regionów, http://www.karpacki.pl/euroregion-fundu sze_unijne-dane_ogolne-35.html [dostęp 12.04.2014].

3 R. Radek, op. cit., s. 140.

4 F. Köning, Południowy Tyrol - trudna droga do pojednania w duchu europejskim, [w:] M. Zalewska-Zemła (red.), Euroregiony, Gliwice 1993, s. 33-36. 
pomiędzy regionami. Przykładem takiego rozwiązania było powołanie Euroregionu Transmache pomiędzy Francją, Wielką Brytanią i Belgią ${ }^{5}$.

Ciekawym przykładem euroregionów są te powstałe na granicy Irlandii Północnej i Republiki Irlandii, które działają w oparciu o realizację priorytetów, wśród których można wyróżnić działania na rzecz poprawy środowiska naturalnego, infrastruktury, rozwoju handlu i przemysłu.

Często euroregiony tworzone są w celu realizacji konkretnego projektu, tak jak choćby w Euregio czynnikiem decydującym o powołaniu euroregionu było powstanie stacji kolejowej w mieście Coevorden. Z kolei Euroregion Scheldemond jest wynikiem realizacji wspólnych celów gospodarczych Belgii i Holandii, a jego znaczenie wynika z bliskości portu w Antwerpii. Celem Euroregionu było utworzenie kanału komunikacyjnego, dzięki któremu duże statki żeglugi morskiej uzyskały swobodny dostęp do portu w Antwerpii ${ }^{6}$.

\subsection{Euroregionalizacja w Europie Środkowo- -Wschodniej - specyfika tworzenia i funkcjonowania}

Rozwój euroregionów w Europie Środkowo-Wschodniej jest wynikiem przemian ustrojowych oraz transformacji systemów politycznych i gospodarczych, które miały miejsce na początku lat 90 . XX w. Współpraca euroregionalna rozwijała się szczególnie na granicach zewnętrznych Unii Europejskiej, gdyż była wspierana środkami finansowymi z krajów Wspólnoty. Zapoczątkowane przemiany zaowocowały utworzeniem w Europie Środkowo-Wschodniej wielu euroregionów, których celem była nie tylko aktywizacja terenów przygranicznych, lecz także integracja tej części Starego Kontynentu z państwami Europy Zachodniej

Zmiany systemu politycznego w Europie Środkowo-Wschodniej doprowadziły nie tylko do odzyskania suwerenności politycznej i demokratyzacji państw, lecz także umożliwiły odrodzenie gospodarki rynkowej, rozwój samorządności lokalnej i świadomości regionalnej. Czynniki te miały decydujący wpływ na rozwój współpracy euroregionalnej w tej części Europys. Euroregiony odegrały istotną

\footnotetext{
5 http://www.regiontransmanche.com/index.html [dostęp 25.04.2014].

6 R. Radek, op. cit., s. 145-146.

7 A. Warych-Juras, Euroregiony jako nowa forma współpracy europejskiej, „Informator Polskiego Towarzystwa Geograficznego Oddział w Krakowie", t. 1/2003, s. 179-180.

8 http://www.kamillo.bpl.vectranet.pl/eurokraszak/PODSTRONY/euroregiony.htm [dostęp 16.05.2014].
} 
rolę w transformacji przestrzeni w Europie Środkowo-Wschodniej. Determinantami rozwoju euroregionów były przede wszystkim:

- przekształcenia systemów społeczno-gospodarczych,

- zwiększenie autonomii regionów i samorządów,

- konieczność nawiązania współpracy transgranicznej w celu budowy dobrych stosunków z państwami sąsiednimi,

- rozwiązanie szeregu problemów gospodarczych, społecznych i ekologicznych w regionach przygranicznych (peryferyjnych),

- uczestnictwo państw Europy Środkowej i Wschodniej w konwencjach międzynarodowych traktujących o współpracy transgranicznej,

- określenie standardów prawnych i unifikacja prawa w celu nawiązania lepszej współpracy pomiędzy regionami,

- pojawienie się szeregu inicjatyw społeczności lokalnych mających na celu rozwój obszarów współpracy z zagranicą ${ }^{9}$.

Główną przesłanką współpracy euroregionalnej w Europie Środkowo-Wschodniej jest konieczność aktywizacji gospodarczej i społecznej regionów przygranicznych ${ }^{10}$. Działania podejmowane są w zakresie rozwoju infrastruktury technicznej, rozwoju przejść granicznych, ochrony środowiska naturalnego, rozwoju turystyki, przepływu siły roboczej, handlu transgranicznego ${ }^{11}$.

Kluczowe znaczenie dla rozwoju euroregionów w Europie Środkowo-Wschodniej miało powołanie w $1991 \mathrm{r}$. Euroregionu Nysa, poprzedzone podpisaniem układu stowarzyszeniowego Polski z Unią Europejską. Był to kluczowy moment w nawiązaniu współpracy transgranicznej pomiędzy państwem wchodzącym w skład UE i państwem bloku wschodniego ${ }^{12}$. Kolejne euroregiony zaczęły powstawać w oparciu o inicjatywy samorządów lokalnych i regionalnych ${ }^{13}$.

Współpraca transgraniczna w Europie rozwija się, a jej efektem jest powstanie ponad 180 regionów transgranicznych o różnym stopniu instytucjonalizacji. Polska zaangażowana jest we współpracę w 18 strukturach współpracy transgranicznej, Czechy - w 13, Słowacja - w 11, Litwa, Rosja, Białoruś i Ukraina - w 4 każda.

9 S. Trojan, J. Tyszczenko, Wpływ procesów demokratyzacji w państwach Europy Środkowo-Wschodniej na współpracę transgraniczna, [w:] M. Malikowski, D. Wojakowski (red.), Granice i pogranicza nowej Unii Europejskiej: Z badań regionalnych, etnicznych i lokalnych, Kraków 2005, s. 98-117.

10 T. Borys, Problemy statystyki transgranicznej, ,'Wiadomości Statystyczne”, nr 9/1999, s. 43.

11 S. Ogrodowicz, Ruch i handel graniczny oraz ich skutki społeczne i ekonomiczne, „Wiadomości Statystyczne", nr 11/1999, s. 42-44.

12 Euroregiony w Polsce, http://www.karpacki.pl/euroregion-fundusze_unijne-euroregiony_ w_polsce-37.html [dostęp 17.05.2014].

13 A. Żelazo, Współpraca międzynarodowa gmin przygranicznych, „Polski Instytut Spraw Międzynarodowych. Biuletyn", nr 59/2002, s. 531-534. 
Niemcy podjęły współpracę w $27^{14}$. Pierwsze euroregiony we wschodniej części kontynentu powstały na zachodniej granicy Polski. Głównymi przyczynami tworzenia nowych zinstytucjonalizowanych form współpracy transgranicznej były:

- nowy kształt granicy zachodniej Rzeczpospolitej Polskiej, która stała się zewnętrzną granicą Unii Europejskiej,

- zawarcie układu stowarzyszeniowego z UE, w myśl którego współpraca transgraniczna pomiędzy Niemcami i Polską nabrała prekursorskiego charakteru,

- społeczności regionów przygranicznych zaczęły wykazywać coraz większą aktywność i chęć nawiązywania kontaktów społecznych i gospodarczych z mieszkańcami regionów po drugiej stronie granicy,

- wewnętrzne granice pomiędzy Polską, Czechami i Słowacją (Państwami Grupy Wyszehradzkiej) nabrały nowego znaczenia, gdyż stały się granicami pomiędzy państwami stowarzyszonymi z UE ${ }^{15}$.

Proces tworzenia euroregionów w Europie Środkowo-Wschodniej zainicjowany został przez stronę niemiecką, która żywo zainteresowana była rozwojem swojej wschodniej granicy ${ }^{16}$. Euroregiony wschodnioeuropejskie tworzono w oparciu o ich zachodnioeuropejskie odpowiedniki, które również stanowią swego rodzaju pomosty w integracji europejskiej, przyczyniają się do rozwoju i aktywizacji społecznej, gospodarczej i kulturowej regionów przygranicznych, niwelowania konfliktów etnicznych i regionalnych ${ }^{17}$.

\subsection{Euroregionalizacja w Polsce}

Reorientacja systemu społecznego, gospodarczego i politycznego w kierunku demokratycznego państwa prawa i gospodarki rynkowej spowodowały włączenie się Polski do struktur integracyjnych Zachodu ${ }^{18}$. Zwiększenie aktywności samorządów lokalnych oraz przystąpienie do Unii Europejskiej stało się bardzo ważnym krokiem w kształtowaniu polskich euroregionów ${ }^{19}$.

14 A. Miszczuk, Współpraca transgraniczna, http://www.euroreg.uw.edu.pl/doc/Akademia 2007_2008/Sesja_IX/MISZCZUK/Miszczuk_wspolpraca_transgraniczna.pdf [dostęp 17.05.2014].

15 H. Rasz, Euroregiony na granicach Polski, Informacja nr 686(IX) 1999, s. 13.

16 Współpraca transgraniczna w Europie, s. 17, http://www.stat.gov.pl/cps/rde/xbcr/wroc/ ASSETS_14-19.pdf [dostęp 20.05.2014].

17 M. Greta, Euroregionalizacja i jej wpływ na lokalny rynek pracy, [w:] D. Kopycińska (red.), Działania ekonomiczne podmiotów rynkowych, Katedra Mikroekonomii Uniwersytetu Szczecińskiego, Szczecin 2007, s. 189.

18 M. Kulesza, Transformacja ustroju administracyjnego Polski (1990-2000), "Studia luridica”, nr XXXVIII/2000, s. 79-80.

19 J. Kuźmicka, J. Bentkowska, Współpraca transgraniczna w euroregionie Pradziad, http://www. europradziad.pl/doce/050123_wspolpraca.doc, s. 1-2 [dostęp 26.05.2015]. 
Euroregiony na granicy zachodniej zazwyczaj posiadają znacznie większe zasoby finansowe i ludzkie, a ich głównym celem jest nawiązywanie współpracy polsko-niemieckiej. Euroregiony rozlokowane wzdłuż granicy wschodniej wykazują zdecydowanie niższy potencjał wzrostowy, jednakże z punktu widzenia przebiegu dalszych procesów integracyjnych i przyjmowania do Unii Europejskiej nowych członków mają one kluczowe znaczenie, gdyż wschodnia granica Polski jest jednocześnie granicą całej Wspólnoty.

Współpraca euroregionalna prowadzona jest ze wszystkimi państwami graniczącymi z Polską. Swoim zasięgiem obejmuje nie tylko regiony przygraniczne, lecz także, jak w przypadku Euroregionu Karpackiego, Węgry i Rumunię czy w przypadku Euroregionu Bałtyk - Danię i Łotwę ${ }^{20}$. Na polskich granicach funkcjonuje obecnie osiemnaście euroregionów, w tym ${ }^{21}$ :

- cztery na granicy zachodniej - z Republiką Federalną Niemiec - działają dwa dwustronne euroregiony: Sprewa-Nysa-Bóbr, Pro Europa Viadrina oraz dwa trójstronne: ze Szwecją - Pomerania i z Czechami - Nysa;

- osiem na granicy południowej - z Czechami i Słowacją - sześć dwustronnych euroregionów: Tatry, Śląsk Cieszyński, Silesia, Pradziad, Glacensis, Dobrava, jeden trójstronny - Beskidy oraz jeden pięciostronny z Węgrami, Rumunią, Ukrainą i Słowacją - Euroregion Karpacki;

- trzy na granicy wschodniej - z Ukrainą, Białorusią i Litwą - działa jeden dwustronny Euroregion Puszczy Białowieskiej, jeden trójstronny Euroregion Bug i jeden czterostronny z Obwodem Kaliningradzkim Federacji Rosyjskiej - Euroregion Niemen;

- trzy na granicy północnej - z Obwodem Kaliningradzkim Federacji Rosyjskiej - działają dwa dwustronne - Euroregion Szeszupa i Łyna-Ława oraz jeden sześciostronny Euroregion Bałtyk z udziałem jednostek terytorialnych z Danii, Litwy, Łotwy, Rosji i Szwecji.

Podobnie jak w innych krajach Unii Europejskiej, tak i w Polsce nazewnictwo euroregionów jest bardzo silnie związane $\mathrm{z}$ otaczającym je środowiskiem geograficzno-przyrodniczym. Nazwy euroregionów pochodzą od nazw rzek, pasm górskich czy akwenów. Przykładem euroregionów, które zaczerpnęły nazwy od rzek są Euroregion: Nysa, Bug, Niemen, Łyna-Ława, od pasm górskich Euroregion Karpaty, od nazwy morza Euroregion Bałtyk, od krainy geograficznej: Pomerania, Silesia czy Śląsk Cieszyński, od nazwy kompleksu leśnego - Euroregion Puszcza Białowieska ${ }^{22}$.

20 S. Hajduk, Szlaki turystyczne jako element integracji regionów transgranicznych, "Człowiek i Środowisko", nr 31(3-4)/2007, s. 90.

21 Ibidem, s. 90-91; Główny Urząd Statystyczny, Stan współpracy euroregionalnej w Polsce, http://www.stat.gov.pl/cps/rde/xbcr/wroc/ASSETS_20-30.pdf [dostęp 12.03.2013].

22 H. Dumała, Czy istnieje model „polskiego" euroregionu?, [w:] W. Malendowski, M. Szczepaniak (red.), Euroregiony: mosty do Europy bez granic, Wydawnictwo Elipsa, Warszawa 2000, s. 59. 
Cechą charakterystyczną polskich euroregionów jest ich zróżnicowanie pod względem wielkości. Dysproporcja szczególnie widoczna jest na wschodniej i zachodniej granicy. Euroregiony powstałe na granicy zachodniej zajmują mniejszą powierzchnię niż te na granicy północnej i wschodniej. Wynika to z tego, że do porozumień euroregionalnych na zachodniej granicy przystępowały poszczególne gminy (porozumienia zawierane są przez związki regionalne i stowarzyszenia), natomiast do euroregionów na granicy wschodniej i północnej przystępowały całe województwa (porozumienia podpisywane były przez wojewodów) ${ }^{23}$.

Współpraca euroregionalna, w której uczestniczy strona polska, zajmuje łącznie obszar 547206 km² (8\% powierzchni Europy). Przeciętna wielkość euroregionu wynosi $32200 \mathrm{~km}^{2}$. Największymi euroregionami są Euroregion Bałtyk, Niemen, Bug i Karpacki, natomiast najmniejsze to Euroregion Silesia, Śląsk Cieszyński, Glacensis i Pradziad ${ }^{24}$. Średnia gęstość zaludnienia w euroregionach wynosi 79 osób na $\mathrm{km}^{2}$. Największą gęstość zaludnienia mają najmniejsze euroregiony położone na południu kraju, wzdłuż granicy z Czechami: Śląsk Cieszyński i Silesia. Najmniejszą gęstość zaludnienia mają euroregiony Niemen i Tatry. Należy podkreślić, że struktura i wielkość euroregionów może się zmieniać. Przykładem może być tu Euroregion Sprewa-Nysa-Bóbr, do którego w 1997 r. dołączyły nowe gminy czy też Euroregion Karpacki, do którego przyłączyło się ówczesne województwo tarnowskie. Co do zasady do euroregionów mogą przystępować również nowe podmioty zagraniczne, jak było to w przypadku Euroregionu Bug, gdzie do współpracy przyłączyła się Białoruś, w przypadku Euroregionu Karpackiego - Rumunia.

Współpraca euroregionalna może obejmować dwa modele: lokalny (samorządowy) oraz rządowy (administracyjny). Model administracyjny występuje w euroregionach utworzonych na wschodniej i północnej granicy Polski (Karpacki, Bug, Niemen i Bałtyk), natomiast samorządowy w euroregionach na zachodzie i południu Polski (Pomerania, Pro Europa Viadrina, Sprewa-Nysa-Bóbr, Nysa, Glacensis, Pradziad, Silesia, Śląsk Cieszyński, Beskidy i Tatry) ${ }^{25}$.

Euroregiony położone na zachodniej granicy mają większe możliwości rozwojowe niż ich odpowiedniki na wschodniej granicy ${ }^{26}$. Należy jednak pamiętać, że dla Unii Europejskiej również euroregiony na jej zewnętrznej, wschodniej granicy mają duże znaczenie. Związane jest to nie tylko z realizacją unijnej polityki kohezji społeczno-gospodarczej i terytorialnej, lecz także z dalszym przebiegiem procesów integracyjnych z dawnymi wschodnimi republikami byłego Związku Radzieckiego. Mimo podejmowanych działań euroregiony wschodnie posiadają mniej-

23 A. Mierosławska, Euroregiony na granicach Polski, Wydawnictwo Instytutu Ekonomiki Rolnictwa i Gospodarki Żywnościowej, Warszawa 1999, s. 43-44.

24 S. Hajduk, op. cit., s. 94.

25 Ibidem, s. 95.

26 A. Żelazo, Współpraca międzynarodowa gmin przygranicznych, „Polski Instytut Spraw Międzynarodowych. Biuletyn", nr 59/2002, s. 532-533. 
szą liczbę gmin partnerskich, na co niewątpliwie wpływ ma sytuacja gospodarcza i geopolityczna w regionie.

Rozwój euroregionów jest ważnym elementem realizacji polityki spójności społeczno-gospodarczej Unii Europejskiej. W promowanie i organizowanie współpracy euroregionalnej zaangażowane są Rada Europy, Rada Gmin i Regionów Europy. Unia Europejska utworzyła szereg programów finansowych wspierających współpracę transgraniczną. Dużą rolę w rozwoju polskich euroregionów odgrywają również rządowe programy wspierania i rozwoju poszczególnych regionów (Narodowa Strategia Spójności) ${ }^{27}$.

Początek współpracy polskich gmin z ich zagranicznymi odpowiednikami miał miejsce w latach 1990-1994 ${ }^{28}$. Zawarto wówczas traktaty, umowy i porozumienia ze wszystkim państwami graniczącymi z Polską ${ }^{29}$, w tym: Konwencję Madrycka Polska (1993 r.) $)^{30}$, Europejską Kartę Samorządu Terytorialnego (1993 r. $)^{31}$ i Europejska Karte Samorzadu Regionalnego (1997 r.) ${ }^{32}$. Poza wymienionymi aktami prawa międzynarodowego zasady współpracy reguluje Ustawa $z 15$ września 2000 roku o zasadach przystępowania wszystkich jednostek samorzadu terytorialnego do międzynarodowych zrzeszeń społeczności lokalnych i regionalnych ${ }^{33}$.

Cele polskich euroregionów mają wymiar gospodarczy, społeczny i w zakresie ochrony środowiska naturalnego ${ }^{34}$. Większość euroregionów posiada opracowane programy rozwoju regionalnego, obejmujące szeroki zakres współpracy społecznej, gospodarczej i kulturalnej. Koncepcje planów zagospodarowania przestrzennego są zróżnicowane. Można jednak dostrzec pewną prawidłowość. Euroregiony na granicy zachodniej korzystają $\mathrm{z}$ doświadczeń pierwszego powstałego w Polsce

27 Ibidem, s. 533.

28 Europejska Konwencja Ramowa o Współpracy Transgranicznej między Wspólnotami i Władzami Terytorialnymi sporządzona w Madrycie dnia 21 maja 1980 r. (Dz.U. z 1993 r.).

29 J. Korczak, Ewolucja form współdziałania jednostek samorzq̨du terytorialnego na forum międzynarodowym, [w:] J. Sługocki (red.), Samorząd terytorialny w Polsce i w Europie. Doświadczenia i dylematy dalszego rozwoju, Bydgoszcz 2009, s. 331-345.

30 Fragment wypowiedzi Podsekretarza Stanu w MSWiA na Konferencji Rady Europy o współpracy transgranicznej, https://www.mswia.gov.pl/pl/aktualnosci/2502,Konferencja-RadyEuropy-o-wspolpracy-transgranicznej.pdf [dostęp 21.04.2009].

31 Euroregion Karpacki, Geneza i rozwój euroregionów, http://www.karpacki.pl/euroregionfundusze_unijne-dane_ogolne-35.html [dostęp 12.06.2014].

32 Ibidem.

33 M. Furmankiewicz, Polskie samorządy gminne w organizacjach międzynarodowych, Uniwersytet Wrocławski, Wrocław 2004, s. 301; Ustawa z dnia 15 września 2000 r.o zasadach przystępowania jednostek samorzq̨du terytorialnego do międzynarodowych zrzeszeń społeczności lokalnych i regionalnych (Dz.U. z 2000 r., nr 91, poz. 1009). Tekst obowiązuje od 27 października 2002.

34 W. Malendowski, M. Ratajczak, Euroregiony - pierwszy krok do integracji europejskiej, Wydawnictwo Alta 2, Wrocław 1998, s. 8; W. Malendowski, M. Szczepaniak, Rola euroregionów w procesie integracji europejskiej, [w:] W. Malendowski, M. Szczepaniak (red.), Euroregiony - mosty bez granic, Wydawnictwo Dom Wydawniczy Elipsa, Warszawa 2000, s. 11-18. 
Euroregionu Nysa. Zarys koncepcji zagospodarowania przestrzennego został tam opracowany przez trójstronną grupę roboczą. Dla porównania w regionach administracyjno-samorządowych o planach zagospodarowania przestrzennego mogą decydować zespoły naukowców (Euroregion Bug, Bałtyk) ${ }^{35}$.

Euroregiony umożliwiły powstanie specjalnych stref ekonomicznych na obszarach peryferyjnych i przyczyniły się do utworzenia wielu nowych firm funkcjonujących na uprzywilejowanych zasadach (Suwalska Strefa Ekonomiczna w Euroregionie Niemen czy Kostrzyńsko-Słubicka Strefa Ekonomiczna w Euroregionie Pro Europa Viadrina). Dynamicznie rozwija się również współpraca w dziedzinie ochrony środowiska naturalnego, współpracy naukowej, badawczej i kulturowej. Strategicznym celem polskich euroregionów jest optymalne wykorzystanie ich wewnętrznego potencjału rozwojowego oraz jak najbardziej efektywne spożytkowanie środków pomocowych z Unii Europejskiej ${ }^{36}$.

\subsection{Realizacja koncepcji rozwoju zrównoważonego w polskich euroregionach - warunki, efekty}

Działania ukierunkowane na zapewnienie trwałego i zrównoważonego rozwoju ujmowane są w euroregionalnych strategiach ekorozwoju ${ }^{37}$. Zasadność wdrażania idei zrównoważonego rozwoju na poziomie regionalnym jest zgodna $\mathrm{z}$ zapisami Agendy $21^{38}$. Programy rozwoju polskich euroregionów uwzględniają ich indywidualne cechy fizyczno-geograficzne. Kwestie ochrony środowiska i rozwoju gospodarczego, jako że bardzo często mają charakter regionalny, najbardziej efektywnie rozwiązywane mogą być przez lokalne działania ${ }^{39}$.

Słuszność realizacji koncepcji zrównoważonego i trwałego rozwoju w euroregionach wynika $\mathrm{z}$ tego, że jednolite systemy środowiskowe bardzo często wykra-

35 A. Warych-Juras, Euroregiony jako nowa forma współpracy europejskiej, „Informator Polskiego Towarzystwa Geograficznego Oddział w Krakowie", t. 1/2003, s. 183.

36 P. Żuber, Rozwój regionalny w Polsce. Raport 2009, Ministerstwo Rozwoju Regionalnego, Warszawa 2009, s. 7.

37 G. Grzelak, Ekorozwój w Euroregionie "Sprewa-Nysa-Bóbr". Projekt Pilotażowy, Gubin 2000, s. 5.

38 I. Rumianowska, Euroregionalny Program Rozwoju Zrównoważonego w Euroregionie Sprewa -Nysa-Bóbr, [w:] B. Fiedor, J. Rymarczyk (red.), Ekonomia i międzynarodowe stosunki gospodarcze, Wydawnictwo Akademii Ekonomicznej im. Oskara Langego, Wrocław 2007, s. 128.

39 T. Borys, W stronę zrównoważonego rozwoju polskich gmin i powiatów, [w:] T. Borys (red.), Zarządzanie zrównoważonym rozwojem. Agenda 21 w Polsce - 10 lat po Rio, Wydawnictwo Ekonomia i Środowisko, Białystok 2003, s. 41-42. 
czają poza obszar pojedynczej gminy, a konieczne jest ich objęcie jednolitym programem ochrony środowiska. Ponadto kompetencje władz poszczególnych gmin obejmują tylko podległe im obszary, co bardzo często uniemożliwia efektywne działania na rzecz poprawy stanu środowiska naturalnego ${ }^{40}$.

Euroregiony powstałe na granicy zachodniej są efektem inicjatyw oddolnych, a uczestnictwo $\mathrm{w}$ nich uwarunkowane jest przystąpieniem do lokalnych stowarzyszeń jednostek samorządowych po obu stronach granicy ${ }^{41}$. Charakteryzują się one różną powierzchnią, odmienną gęstością zaludnienia i posiadają odrębne cele szczegółowe, ukierunkowane na zrównoważony rozwój regionów przygranicznych.

Euroregiony położone przy południowej granicy Polski mają podobny potencjał rozwojowy. Podstawowymi rodzajami działalności gospodarczej w euroregionach przy granicy z Czechami są handel, usługi i budownictwo. Natomiast przy granicy ze Słowacją dominują handel, hotelarstwo, gastronomia i transport. Rozwój pogranicza w dużym stopniu uzależniony jest od turystyki ${ }^{42}$.

Cechą charakterystyczną euroregionów polskiego pogranicza wschodniego jest wysoki stopień ich peryferyjności i niski poziom rozwoju. Dominującą gałęzią gospodarki jest rolnictwo. Wschodnia granica Polski oddziela obszary zamieszkałe przez ludność posiadającą wspólną historię, tradycję i pochodzenie etniczne ${ }^{43}$. Euroregiony wschodnie mają dużą powierzchnię, gdyż sygnatariuszami Statusów powołujących zinstytucjonalizowaną współpracę byli wojewodowie, a do współpracy przystępowały całe województwa ${ }^{44}$.

\subsubsection{Efekty współpracy euroregionalnej na pograniczu zachodnim}

Efekty funkcjonowania współpracy euroregionalnej można dostrzec zarówno $\mathrm{w}$ aspekcie społecznym, gospodarczym, jak i ochrony środowiska naturalnego ${ }^{45}$. Rozwój zrównoważony w euroregionach dokonuje się poprzez wsparcie różnorodnych działań o charakterze transgranicznym w obszarach, takich jak: ułatwianie samorządom gminnym i mieszkańcom dostępu do funduszy unijnych, promocja gospodarcza i rozwój sektora małych i średnich przedsiębiorstw, tworzenie ponad-

40 I. Rumianowska, op. cit., s. 129.

41 J. Pułkownik, Euroregion Pro Europa Viadrina jako przykład współpracy transgranicznej, "Zeszyty Studiów Doktoranckich/Uniwersytet Ekonomiczny w Poznaniu", nr 43/2005, s. 25.

42 A. Krakowiak-Bal, Potencjał gospodarczy gmin przygranicznych Polski Południowej, "Infrastruktura i Ekologia Terenów Wiejskich", nr 2/2/2006, s. 149-158.

43 B. Kawałko, Granica wschodnia jako czynnik ożywienia i rozwoju społeczno-ekonomicznego regionów przygranicznych. Synteza, Ekspertyza dla Ministerstwa Rozwoju Regionalnego, Warszawa 2008, s. 622.

44 S. Hajduk, op. cit., s. 94.

45 Centrum Informacji Europejskiej Urzędu Komitetu Integracji Europejskiej http://www.cie. gov.pl [dostęp 12.01.2015]. 
granicznych koncepcji rozwoju przestrzenno-gospodarczego, prowadzenie działań o charakterze kulturalno-oświatowym, tworzenie infrastruktury technicznej i przejść granicznych ${ }^{46}$.

\section{Aspekt gospodarczy}

W Euroregionie Pomerania powstał wspólny obszar gospodarczy Odry, regionu wybrzeża i Zalewu Szczecińskiego ze związkiem z obszarem metropolitarnym Berlina i regionem cieśniny Öresund. Głównym celem wspólnego obszaru gospodarczego jest przyciąganie inwestorów, wspieranie innowacyjności, zapewnianie rozwoju transportu w regionie, skoordynowanie współpracy gospodarczej, tworzenie struktur turystycznych ${ }^{47}$. Wsparciem dla działań z zakresu gospodarki zajmują się centra usługowo-doradcze, które mają za zadanie zapewnić przedsiębiorstwom i obywatelom informacje dotyczące funkcjonowania podmiotów gospodarczych po obu stronach granicy. W Euroregionie Pomerania funkcjonuje międzynarodowa sieć kooperacji, która dzięki wsparciu Inicjatywy Wspólnotowej Interreg IIIB dla basenu Morza Bałtyckiego realizuje cząstkowe i tematyczne projekty, związane $z$ funkcjonowaniem i rozwojem instytucji, miast, uczelni wyższych ${ }^{48}$. Szczególną rolę dla gospodarki Euroregionu odgrywają małe i średnie przedsiębiorstwa, które otrzymują wsparcie transgranicznych centrów serwisowych oraz coaching dla branż z zakresu usług inżynierskich, technologii informatycznych, opieki medycznej i turystyki. W rezultacie podjętych działań nastąpiła poprawa połączeń komunikacyjnych i ich lepsze wykorzystanie na rzecz rozwoju w Euroregionie (integracja dróg wodnych na południowym Bałtyku - Baltic Gateway, Baltic+). Wprowadzono alternatywne koncepcje dla rozwoju obszarów wiejskich, przeprowadzając restrukturyzację gospodarki rolnej i leśnej (BALTIC+, High Quality Tourism). Stworzono również transnarodową sieć dróg dla turystyki wodnej, która wykorzystywana jest jako czynnik ekonomiczny pobudzający rozwój i zwiększający ilość miejsc pracy ${ }^{49}$.

W Euroregionie Pro Europa Viadrina rozwija się współpraca gospodarcza, która oparta została nie tyko na współpracy samorządów, lecz także na działaniach podejmowanych przez organizacje pozarządowe, organizacje pracodawców (Izby Przemysłowo-Handlowe w Gorzowie Wielkopolskim i we Frankfurcie nad

46 Euroregiony, http://marketcontact.eu/pl/wiadomosci-gospodarcze/91-euroregiony.html [dostęp 12.09.2014].

47 W.O.W. Kommunalberatung und Projektbegleitung GmbH, Döllinger Architekten Inregia AB Stockholm Inros Lackner AG Rostock, Regionalne Biuro Gospodarki Przestrzennej Województwa Zachodniopomorskiego, Transgraniczna koncepcja działań i rozwoju Euroregionu POMERANIA na lata 2007-2013, Szczecin 2006, s. 12-14.

48 Euroregion Pomerania, Transgraniczna koncepcja działań i rozwoju Euroregionu POMERANIA na lata 2007-2013, s.25, http://www.pomerania.net/download/EHK_POMERANIA_2007-13_ Endfassung_PL.pdf [dostęp 18.03.2013]. 
Odrą) i organizacje pracownicze. W Euroregionie znajduje się dobrze rozbudowana planistycznie sieć obszarów przemysłowych oraz duża liczba małych i średnich przedsiębiorstw.

W Euroregionie Sprewa-Nysa-Bóbr powstało Regionalne Biuro Współpracy Zielona Góra-Cottbus, którego głównym zadaniem jest przekazywanie informacji i danych rynkowych dla podmiotów gospodarczych. Wprowadzono ułatwienia w uzyskiwaniu zezwoleń i dostępie do informacji o zamówieniach publicznych, organizowane są seminaria, szkolenia i doradztwo zawodowe ${ }^{50}$. Do 2006 r. w ramach projektu Zdobywanie rynku w Polsce zawarto dwadzieścia siedem porozumień o współpracy pomiędzy przedsiębiorstwami z niemieckiej i polskiej części Euroregionu. Udało się stworzyć korzystne warunki dla współpracy pomiędzy podmiotami gospodarczymi z Polski i Niemiec. Władze Euroregionu kładą nacisk na współpracę szkół wyższych z przedsiębiorstwami, w tym wprowadzanie innowacji przy wydobyciu węgla czy uzyskiwaniu energii ze źródeł alternatywnych (np. Agro-Sieć Biomasa - współpraca producentów, naukowców i przetwórstwa).

$\mathrm{Na}$ przestrzeni lat funkcjonowania Euroregionu Neisse-Nysa-Nisa nastąpił wzrost regionu w obszarze gospodarczym poprzez zawiązanie ściślejszej współpracy w dziedzinie gospodarki i turystyki. Euroregion charakteryzuje się bogatym zapleczem akademickim, a także dużą liczbą małych i średnich przedsiębiorstw. Kluczowe branże to przemysł metalowy, budowa maszyn (produkcja tramwajów, pociągów, produkcja maszyn rolniczych, części samochodowych), przemysł tekstylny i informatyczny. Rozwój współpracy transgranicznej odbywa się również poprzez tworzenie sieci przedsiębiorstw transgranicznych działających w oparciu o wspólne strategie rozwoju i korzystające ze współpracy z jednostkami akademickimi. Ścisła współpraca pomiędzy podmiotami gospodarczymi i jednostkami samorządowymi z Czech, Niemiec i Polski stała się codziennością. Władze euroregionalne promują rozwój innowacyjności, przyznając raz w roku nagrodę „Innowacja - Euroregion Neisse-Nisa-Nysa" dla podmiotów gospodarczych wprowadzających innowacje. Za rozwój gospodarczy w Euroregionie odpowiada grupa robocza Eurex Gospodarka, której nadrzędnym celem jest stworzenie strategii dotyczącej wspólnej przestrzeni gospodarczej i życiowej. W Euroregionie ma miejsce również szeroko zakrojona współpraca w dziedzinie turystyki, która w ostatnim okresie skupia się na projektach, takich jak: nowa droga grzbietowa wzdłuż wspólnej granicy, uczestnictwo w regionalnych targach turystycznych czy włączenie budowli sakralnych do projektu turystycznego Via Sacra ${ }^{51}$. Założeniem współpra-

50 Euroregion Sprewa-Nysa-Bóbr, Plan rozwoju i działania euroregionu, http://euroregionsnb.pl/media/dokumenty/Ogolne/plan_rozwoju_i_dzialania_euroregionu_sprewa_nysa_ bobr.pdfs.65 [dostęp 15.05.2015].

51 H. Grosse, Euroregion Neisse-Nysa-Nisa na drodze do wspólnej przestrzeni gospodarczej, [w:] M. Zdulski (red.), 20 lat współpracy transgranicznej w Euroregionie Neisse-Nysa-Nisa, Wydawnictwo Ad Rem, Jelenia Góra 2011, s. 25-27. 
cy w Euroregionie był rozwój gospodarczy i pogłębianie współpracy gospodarczej samorządów. Rezultatem podjętych działań jest przede wszystkim nagroda „Innowacji Regionu”, opracowanie wspólnej Koncepcji rozwoju ERN, powołanie samorządu gospodarczego Euroregionu Nysa, publikacja czasopism o tematyce gospodarczej. Pozytywnym efektem współpracy w Euroregionie jest również Koncepcja rozwoju turystyki, utworzenie sieci przejść granicznych, utworzenie sieci rowerowych magistrali w Euroregionie, promocja turystyki regionalnej ${ }^{52}$.

\section{Aspekt społeczny i kulturowy}

W Euroregionie Pomerania funkcjonuje Europejski Portal Mobilności Zawodowej, którego zadaniem jest doradztwo w zakresie polsko-niemieckiego rynku pracy, poszukiwanie ofert pracy po obu stronach granicy, pośrednictwo w poszukiwaniu pracowników z konkretnych dziedzin, ułatwianie współpracy pomiędzy instytucjami ${ }^{53}$. Prowadzone są działania mające na celu podnoszenie poziomu kształcenia zawodowego, ułatwianie adaptacji do nowych miejsc i warunków pracy, walka z wykluczeniem społecznym, tworzone są placówki zdrowotne.

W Euroregionie Pro Europa Viadrina rozwija się współpraca społeczna i kulturowa. Stanowi on siedzibę wielu instytucji i uczelni wyższych ukierunkowanych na rozwój współpracy międzynarodowej. Władze wspierają również projekty z zakresu edukacji, kultury i budowy pozytywnych relacji sąsiedzkich.

W Euroregionie Sprewa-Nysa-Bóbr ma miejsce współpraca akademicka pomiędzy polską a niemiecką częścią Euroregionu. Niemieckie uczelnie BTU Cottbus i Wyższa Szkoła Zawodowa w Lausitz współpracują z polskimi uczelniami. Istnieje tam również szereg instytucji odpowiadających za transfer badań i technologii (np. Centrum Zastosowań Planowania Systemów Logistycznych i Informacyjnych Frauenhofer, Centrum Technologii Energetycznej Brandenburg, szereg instytutów Uniwersytetu Zielonogórskiego $)^{54}$.

W Euroregionie Neisse-Nysa-Nisa funkcjonuje Grupa Robocza Historia, która zajmuje się badaniem wspólnej historii, zwoływane są sympozja i konferencje naukowe np. Sympozjum na temat: Czechy a Górne Łużyce czy też Europa Środkowa-Czechy-Śląsk-Górne Łużyce w grze wielkich mocarstw w XVIII w. W ramach grupy roboczej ma miejsce promocja wspólnej historii i dziedzictwa kulturowego poprzez udział w projekcie Dziedzictwo Kulturowe - Tożsamość - Dialog (Poczdam, Wenecja, Liberec, Görlitz, Jelenia Góra 2005-2006) oraz po-

52 S. Banaszak, Statystyka, [w:] M. Zdulski (red.), 20 lat współpracy transgranicznej w Euroregionie Neisse-Nysa-Nisa, Wydawnictwo Ad Rem, Jelenia Góra 2011, s. 40-43.

53 Euroregion Pomerania, Praca na polsko-niemieckim pograniczu, http://www.pomerania.net/ main.cfm?l=pl\&rubrik=3\&th=5\&newsid=957 [dostęp 10.04.2014].

54 Euroregion Sprewa-Nysa-Bóbr, Plan rozwoju i działania euroregionu, s. 100. 
wstanie projektu pod hasłem Kraina Domów Przysłupowych ${ }^{55}$. W Euroregionie Neisse-Nysa-Nisa funkcjonuje również Grupa Robocza Równość szans, której zadaniem jest „wprowadzenie równych szans dla kobiet i mężczyzn we wszystkich dziedzinach życia społeczno-gospodarczego" ${ }^{\text {56 }}$. Grupa Eurex Edukacja zainicjowała program Szkolny portal informacyjny Euroregionu Neisse-Nysa-Nisa, którego celem jest wymiana doświadczeń i nawiązywanie współpracy i kontaktów w dziedzinie edukacji ${ }^{57}$.

\section{Aspekt ochrony środowiska naturalnego}

W Euroregionie Pomerania podejmowane są działania mające na celu zapewnienie odpowiedniej gospodarki wodnej, gospodarki odpadami, a także zapobieganie klęskom naturalnym. Działania koncentrują się na tworzeniu dogodnych warunków dla rozwoju współpracy w ochronie środowiska (np. kooperacja pomiędzy Parkiem Narodowym Dolnej Odry a polskim parkiem cedyńskim i Doliny Dolnej Odry). Wdrażane są wytyczne unijne w kwestii ochrony środowiska naturalnego. Ich konsekwencją jest utworzenie sieci ekologicznej Natura 2000, w skład której wchodzą dyrektywa siedliskowa (FFH) oraz obszar ochrony ptaków ${ }^{58}$. Składowym elementem euroregionalnej strategii ochrony środowiska naturalnego jest włączenie parków regionalnych do rozwoju społeczno-gospodarczego metropolii (np. region Berlina i Brandenburgii).

Główne projekty z zakresu ochrony środowiska naturalnego realizowane $\mathrm{w} \mathrm{Eu}-$ roregionie Pro Europa Viadrina to budowa oczyszczalni ścieków (w Rzepinie, Słońsku, Sulęcinie) oraz modernizacja oczyszczalni w Gorzowie Wielkopolskim. W ramach ochrony środowiska stworzono kompleksowy program gromadzenia, segregacji i wywozu odpadów komunalnych dla środkowego prawobrzeża Odry. Współpraca obejmuje również zwalczanie klęsk żywiołowych i ponadgraniczną współpracę w zakresie ochrony środowiska naturalnego na terenie Gorzowa i powiatu Märkich-Oderland ${ }^{59}$.

Obszar Euroregionu Sprewa-Nysa-Bóbr charakteryzuje się cenną i bogatą przyrodą i niezwykłym krajobrazem - występuje tu duża liczba chronionych gatunków roślin i zwierząt. Wśród projektów związanych z ochroną środowiska naturalnego realizowanych w Euroregionie można wyróżnić Program Ekorozwoju, projekt turystyczny ścieżek rowerowych, wspólną oczyszczalnię ścieków Gubin

55 M. Winzeler, Historia, [w:] M. Zdulski, 20 lat współpracy transgranicznej w Euroregionie Neisse -Nysa-Nisa, Wydawnictwo Ad Rem, Jelenia Góra 2011, s. 27-31.

56 I. Fabish, Równość szans, [w:] M. Zdulski, 20 lat współpracy transgranicznej w Euroregionie Neisse-Nysa-Nisa, Wydawnictwo Ad Rem, Jelenia Góra 2011, s. 39.

57 R. Gellrich, Edukacja: stan obecny i perspektywy, [w:] M. Zdulski, 20 lat współpracy transgranicznej w Euroregionie Neisse-Nysa-Nisa, Wydawnictwo Ad Rem, Jelenia Góra 2011, s. 44.

58 Euroregion Pomerania, Transgraniczna koncepcja rozwoju, s. 59-60.

59 Stowarzyszenie Gmin Polskich Euroregionu Pro Europa Viadrina, Phare CBC 1994-2000, http://www.euroregion-viadrina.pl/projekty_infra.php [dostęp 10.03.2014]. 
-Guben. Euroregion uczestniczy również w ponadgranicznym projekcie ochrony lasów - EUROLAS (ochrona lasów przed pożarami) oraz ponadgraniczych projektach ochrony środowiska w zakresie zapobiegania, zwalczania i usuwania skutków katastrof naturalnych ${ }^{60}$.

Obszar Euroregionu Neisse-Nysa-Nisa stanowi terytorium, na którym środowisko naturalne zostało wyraźnie zniszczone na skutek negatywnego działania przemysłu. W ramach Euroregionu powstała Grupa Eurex Lasy, której celem była ochrona zasobów przyrody, w szczególności ochrona zagrożonych gatunków zwierząt i ekosystemów. W 2011 r. w ramach współpracy euroregionalnej zorganizowano Dolnośląski Festiwal Leśny we Wrocławiu, Konferencję Leśną Jak ucieka czas lasu i człowieka na zamku Frydlant czy Festiwal Dary Lasu w Lwówku Śląskim $(\mathrm{PL}-\mathrm{D})^{61}$. W Euroregionie funkcjonują również dwie grupy: Ochrona przed katastrofami i Bezpieczeństwo ${ }^{62}$. Efektem współpracy w dziedzinie ochrony środowiska jest zapewnienie wymiany informacji na temat sytuacji ekologicznej, opracowanie Raportu o stanie lasów w Euroregionie Nysa, pogłębianie wiedzy o ochronie przyrody w poszczególnych krajach, organizowanie konferencji poświęconych ochronie środowiska naturalnego. Pozytywnym aspektem funkcjonowania Euroregionu jest również realizacja Programu Czysta Nysa, poprawa jakości i stanu wód, wspieranie budowy oczyszczalni ścieków, zarybianie zasobów wodnych czy walka z klęskami żywiołowymi ${ }^{63}$.

\subsubsection{Efekty współpracy euroregionalnej na pograniczu południowym}

Głównym celem tworzenia euroregionów na pograniczu południowym było nawiązanie współpracy polskich regionów przygranicznych z ich odpowiednikami z Czech i Słowacji. Współpraca ta obejmuje szeroki zakres, począwszy od kwestii gospodarczych, społecznych, kulturowych, po kwestie związane z ochroną środowiska naturalnego i zapewnieniem rozwoju turystyki w regionie.

60 Klub Europejski im. Marii Dąbrowskiej w Płocku, Euroregion Sprewa-Nysa-Bóbr, Płock, http://klubue.3lo.pl/index.php?option=com_content\&view=article\&id=110\&ltemid=86 [dostęp 10.03.2014].

61 Ch. Schurr, Lasy - żywa wymiana w zielonej części Euroregionu Nysa, [w:] M. Zdulski, 20 lat współpracy transgranicznej w Euroregionie Neisse-Nysa-Nisa, Wydawnictwo Ad Rem, Jelenia Góra 2011, s. 10.

62 M. Gałęski, 20 lat ochrony przed zagrożeniami. Przeciwdziałanie i usuwanie skutków katastrof i klęsk na styku granic Niemiec, Czech i Polski, [w:] M. Zdulski, 20 lat współpracy transgranicznej w Euroregionie Neisse-Nysa-Nisa, Wydawnictwo Ad Rem, Jelenia Góra 2011, s. 35-36.

63 S. Banaszak, op. cit., s. 40-43. 


\section{Aspekt gospodarczy}

W Euroregionie Glacensis funkcjonuje czterdzieści dziewięć umów i porozumień partnerskich realizujących oddolne inicjatywy. Na podstawie zawartych porozumień opracowywane są wspólne wnioski do programów pomocowych i realizowane są transgraniczne projekty o charakterze społecznym, gospodarczym, kulturowym. Organizowana jest Konferencja kłodzko-orlicka będąca inicjatywą poświęconą planowaniu przestrzennemu ${ }^{64}$. Wśród zrealizowanych projektów znalazło się m.in. otwarcie drogowego przejścia granicznego Nowa MorawaStaré Město pod Sněžníkem i dwóch przejść granicznych na szlakach turystycznych w Górach Bialskich: Bielice-Papršek, Bielice-Nýžnerov. Udało się również wzmocnić współpracę stowarzyszeń reprezentujących poprzez zintegrowanie instytucji wspierających rozwój kontaktów międzynarodowych pod kątem lepszego pozyskiwania środków $z$ funduszy unijnych.

Obszar Euroregionu Pradziad ma charakter przemysłowo-rolniczy, dominującymi gałęziami przemysłu po polskiej stronie są przemysł chemiczny (Kędzierzyn-Koźle) oraz maszyn i wyrobów z metali ${ }^{65}$. W Euroregionie mają miejsce liczne promocje gospodarcze, organizowane są cykliczne wystawy (np. Wystawy Twórców Ludowych i Rzemiosła Artystycznego Pogranicza Polsko-Czeskiego i Targów „Inter-Region”). Ważnym elementem ułatwiającym współpracę gospodarczą jest baza danych o przedsiębiorstwach funkcjonujących po obu stronach granicy. W Euroregionie organizowane są również przedsięwzięcia $\mathrm{z}$ zakresu promocji i rozwoju turystyki (np. dotyczące „Turystyki Królestwa Pradziad”) ${ }^{66}$.

Euroregion Silesia w pierwszym okresie swojego funkcjonowania włączył się w działania Polsko-Czeskiej Komisji Międzyrządowej ds. Współpracy Transgranicznej, której zadaniem jest rozbudowa i poprawa funkcjonowania przejść granicznych oraz infrastruktury technicznej i drogowej. W Euroregionie realizowane są projekty dotyczące rozwoju sektora MŚP pt. Promowanie $i$ wspieranie małych $i$ średnich przedsiębiorstw $z$ europejskich obszarów górniczych oraz $w$ regionach o tradycji przemysłowej. Innymi projektami realizowanymi w ramach programów współpracy międzyregionalnej EWT są projekty Dzieląc się doświadczeniami Europy - polityki, innowacja i design i Zrównoważona mobilność miejska ${ }^{67}$.

64 Euroregion Glacensis, 15 lat Euroregionu, Projekt współfinansowany ze środków Europejskiego Funduszu Rozwoju Regionalnego w ramach Programu operacyjnego Współpracy Transgranicznej Republika Czeska Rzeczpospolita Polska 2007-2013 oraz budżetu państwa za pośrednictwem Euroregionu Glacensis, s. 12-13.

65 J. Kuźmicka, J. Bentkowska, Współpraca transgraniczna w euroregionie Pradziad, http://www. europradziad.pl/doce/050123_wspolpraca.doc, s. 5 [dostęp 26.05.2015].

66 Ibidem, s. 12.

67 Euroregion Silesia, Europejska Współpraca Terytorialna w latach 2007-2013. Realizacja Programów EWT w Euroregionie Silesia, Efekty Współpracy Transgranicznej, „Biuletyn Euroregionu Silesia", nr 5/2012, s. 2. 
Euroregion Śląsk Cieszyński jest jednym z najmłodszym euroregionów na granicach Polski. Mimo krótkiego okresu funkcjonowania zrealizowano wiele projektów współpracy (np. Inforeg 2000 i Regiotour, których rezultatem było stworzenie bazy informacji odnośnie do imprez kulturalnych, sportowych i gospodarczych $)^{68}$. Opracowano studium przekraczania granic państwowych (projekt Border Crossing), wspólną strategię rozwoju turystyki (projekt Interturism). Powstało również Studium rozwoju pogranicza polsko-czeskiego, a dzięki pozyskaniu środków finansowych udało się zmodernizować infrastrukturę drogową i przygraniczną ${ }^{69}$.

Rozwój Euroregionu Beskidy uwarunkowany jest w znacznej mierze walorami turystycznymi regionu. Realizowane są projekty zachęcające do organizacji turystyki biznesowej (szkoleń, konferencji, spotkań integracyjnych). Aktywnie działają instytucje wsparcia i organizowane są szkolenia z zakresu pozyskiwania dodatkowych środków pieniężnych na realizację projektów społeczno-gospodarczych ${ }^{70}$.

W Euroregionie Tatry, aby rozwijać współpracę gospodarczą i nawiązywać kontakty pomiędzy przedsiębiorstwami po obu stronach granic, powołano organizację Polsko-Słowackiego Forum Gospodarczego. Dzięki wsparciu finansowemu z Unii Europejskiej (z programów PHARE i Interreg III) udało się zrealizować szereg infrastrukturalnych projektów, w tym m.in.: wybudowano Most Wyszehradzki, zmodernizowano granice państwowe i drogi lokalne (np. Leluchów-Dubne -Wojkowa). Utworzono System Informacyjny Euroregionu „Tatry” INFOTATRY, w którym zamieszczono informację o gminach i miastach członkowskich Euroregionu ${ }^{71}$.

\section{Aspekt społeczny}

W Euroregionie Pradziad ma miejsce współpraca mająca na celu zbliżanie społeczności czeskiej i polskiej poprzez organizowanie szeregu akcji promocyjnych, festynów, imprez sportowych, kulturalnych (np. w Prudniku wystawy twórców ludowych pogranicza, w Otmuchowie „Lato kwiatów”, w Nysie „Lato w Euroregionie Pradziad"). Na uwagę zasługuje również powołanie dwujęzycznej szkoły średniej i biznesowej szkoły wyższej. W polskich szkołach istnieje możliwość nauczania w języku czeskim ${ }^{72}$.

W Euroregionie Silesia istnieje szeroko zakrojona współpraca w dziedzinie edukacji, kultury i szkolnictwa. Jej rezultatem jest wydanie czesko-polskiego pod-

68 Euroregion Śląsk Cieszyński, Działalność Euroregionu oraz Stowarzyszenia „OLZA", http://www. greenways.olza.pl/ [dostęp 12.04.2014].

69 Euroregion Śląsk Cieszyński, Sprawozdanie z działalności za rok 2002 Stowarzyszenia Rozwoju i Współpracy Regionalnej "Olza w Cieszynie”, Cieszyn 2003, s. 2-3.

70 Euroregion Beskidy, Mały projekt duży efekt, czyli Mikroprojekty w Euroregionie Beskidy, Bielsko-Biała 2014, s. 5-7.

71 Transgraniczny Związek Euroregion Tatry, Wspólna polsko-słowacka Strategia Rozwoju Euroregionu "Tatry" na lata 2008-2015, Nowy Targ 2008, s. 10-11.

72 J. Kuźmicka, J. Bentkowska, op. cit., s. 12. 
ręcznika edukacyjnego służącego regionalnemu nauczaniu: Wspólne dziedzictwo raciborsko-opawskie. Istnieją ułatwienia dla uczniów i studentów, którzy mają możliwość korzystania z pomocy sekretariatów Euroregionu w zakresie pisania prac naukowych. Euroregion Silesia w 2002 r. nawiązał współpracę w ramach tzw. Czwórki Wyszehradzkiej odnośnie do zawierania umów partnerskich. Rezultatem współpracy było organizowanie wspólnych imprez na terenie Polski, Czech i Węgier ${ }^{73}$.

W Euroregionie Śląsk Cieszyński funkcjonuje baza informacji czesko-polskiej dotycząca imprez kulturalno-sportowych oraz Agencje Informacji Przygranicznej w Cieszynie i w Trzyńcu (Czechy). Ważnym kulturalnym przedsięwzięciem jest realizacja projektu szlaków dziedzictwa kultury Greenways jako nowego produktu turystycznego. Euroregion czynnie uczestniczy również w akcjach i konferencjach promocyjnych oraz imprezach wystawienniczych w Katowicach, Poznaniu, Pradze ${ }^{74}$.

Celem strategicznym Euroregionu Beskidy jest rozwój procesów integrujących społeczność Euroregionu i budujących demokrację lokalną. W ramach współpracy euroregionalnej pozyskiwani są partnerzy zagraniczni do realizacji wspólnych projektów społeczno-kulturalnych. Promowane są działania zmierzające do budowy trwałych więzi i relacji pomiędzy społecznościami lokalnymi po obu stronach granic. Wspierane są działania mające na celu integrację zawodową i społeczną grup defaworyzowanych ${ }^{75}$.

Motywem przewodnim działań podejmowanych w Euroregionie Tatry w aspekcie społeczno-kulturalnym jest podobieństwo języka i podobny styl życia mieszkańców pogranicza polsko-słowackiego ${ }^{76}$. Realizowane są Dni kultury słowackiej w Polsce, Dni kultury polskiej na Słowacji, Festyn Góralski Euroregion bez granic, a także liczne wystawy, publikacje, konferencje. Znamienną rolę w budowaniu pozytywnych relacji pomiędzy społecznościami lokalnymi odegrała realizacja małych projektów „ludzie dla ludzi” kulturalnych, sportowych, społecznych. Ciekawym projektem jest spotkanie siedmiu kultur pogranicza polsko-słowackiego ${ }^{77}$.

\section{Aspekt ochrony środowiska naturalnego}

W Euroregionie Pradziad realizowanych jest szereg projektów mających na celu ochronę środowiska naturalnego oraz rozwój walorów turystycznych na obszarze całego Euroregionu. Przykładem aktywności z zakresu ochrony środowiska

73 J. Novotná-Galuszková, D. Kardaczyńska, M. Siara, Euroregion Silesia, Przekraczamy granice, Wydawnictwo i Agencja Informacyjna WAW Grzegorz Wawoczny, Racibórz 2009, s. 20-25.

74 Euroregion Śląsk Cieszyński, Sprawozdanie z działalności za rok 2002..., s. 2-3.

75 Euroregion Beskidy, Strategia rozwoju euroregionu Beskidy, s. 37-38, http://www.euroregion -beskidy.pl/pl/images/stories/zdjecia/strategiaerb.pdf [dostęp 20.04.2014].

76 Euroregion Tatry, Dodatnie saldo, pytania o przyszłość, "15-lecie Euroregionu Tatry”, nr 80/2010, s. 18.

77 Transgraniczny Związek Euroregion Tatry, Wspólna polsko-słowacka..., s. 9. 
jest wsparcie dla projektu przerzutu ścieków i budowy kanalizacji w dolinie Złotego Potoku (w ramach programu PHARE CBC 2,2 mln euro) ${ }^{78}$.

Euroregion Silesia zgodnie z zapisami statutowymi prowadzi działania mające na celu ochronę środowiska naturalnego. Wśród zrealizowanych projektów są m.in. projekt Redukcja ryzyka oraz skutków zagrożeń naturalnych $i$ wywołanych działalnością człowieka, a także działania mające na celu ochronę przeciwpowodziową w regionach poprzez wzmocnienie działania jednostek Ochotniczych Straży Pożarnych czy ochrona przeciwpowodziowa na pograniczu opawsko-raciborskim poprzez wsparcie finansowe i szkolenia dla służb kryzysowych ${ }^{79}$.

Jednym z priorytetowych celów funkcjonowania Euroregionu Śląsk Cieszyński jest wsparcie działań zmierzających do ochrony środowiska naturalnego. Zrealizowano projekt działań mający na celu monitorowanie zanieczyszczeń z przygranicznych przedsiębiorstw (np. Huta w Trzyńcu) oraz wsparto działania w ramach stworzenia systemu wspólnego ostrzegania przed klęskami żywiołowymi oraz nadmiernym zanieczyszczaniem środowiska naturalnego. Podejmowane są również działania z zakresu gospodarki wodno-ściekowej, a także realizowane szkolenia i programy edukacyjne na temat szkodliwości emisji substancji trujących środowisko ${ }^{80}$.

Jednym z celów Euroregionu Beskidy jest dbanie o bogactwo zasobów przyrody i ochrona środowiska. Realizacja tego celu strategicznego odbywa się poprzez promowanie i wsparcie budowy systemów energetycznych opartych na źródłach odnawialnych (efektem jest ograniczenie stopnia zanieczyszczenia powietrza z emitorów punktowych), produkcję ekologicznej żywności. W Euroregionie utworzono system kształtowania i wykorzystania zasobów wodnych, uporządkowano system gospodarki odpadami i zachowano tereny szczególnie ważne ze względu na bogate zasoby środowiska przyrodniczego ${ }^{81}$.

Bogactwo zasobów naturalnych i szeroki wachlarz rozwoju turystyki w Euroregionie Tatry wymaga podejmowania działań służących ochronie środowiska naturalnego. Realizowanych jest wiele projektów mających wpłynąć na poprawę stanu zasobów przyrody. W ramach programu PHARE CBC zrealizowano projekty: Czysta rzeka - dorzecze Popradu i Dunajca, Rozwój infrastruktury ochrony środowiska powiatów Kieżmark, Poprad i Stara Lubowla. Zrealizowano projekt Chronimy i tworzymy krajobraz Euroregionu Tatry.

78 J. Kuźmicka, J. Bentkowska, op. cit., s. 12.

79 Euroregion Silesia, Europejska Współpraca Terytorialna w latach 2007-2013. Realizacja Programów EWT w Euroregionie Silesia. Efekty Współpracy Transgranicznej, „Biuletyn Euroregionu Silesia", nr 5/2012, s. 2-3.

80 Euroregion Śląsk Cieszyński, Sprawozdanie z działalności za rok 2002..., s. 2-3.

81 Euroregion Beskidy, Strategia rozwoju euroregionu Beskidy, s. 42-43, http://www.euroregion -beskidy.pl/pl/images/stories/zdjecia/strategiaerb.pdf [dostęp 15.05.2015]. 


\subsubsection{Efekty współpracy euroregionalnej na pograniczu wschodnim i północnym}

Wschodnia granica Rzeczpospolitej Polskiej jest równocześnie granicą wschodnią całej Unii Europejskiej. Z tego też względu władze Wspólnoty kładą nacisk na rozwój współpracy z państwami, które w przyszłości mogą zostać członkami Unii Europejskiej. Rozwój współpracy euroregionalnej jest również niezwykle ważny z punktu widzenia rozwoju Polski Wschodniej. Ciekawa współpraca odbywa się również na północnej granicy, a jej specyfika wiąże się z tym, że obejmuje ona obszary oddzielone od siebie akwenem wodnym.

\section{Aspekt gospodarczy}

Głównym celem Euroregionu Bug jest inspirowanie, wspomaganie i koordynacja współpracy transgranicznej samorządów, społeczności lokalnych i władz administracyjnych $\mathrm{z}$ obszarów przygranicznych ${ }^{82}$. Euroregion aktywnie korzysta ze środków finansowych z UE, przede wszystkim z Funduszu małych Projektów w ramach PHARE - Polska Granica Wschodnia i Programu Sąsiedztwa Polska -Białoruś-Ukraina Interreg III/TACIS $\mathrm{CBC}^{83}$. Wśród zrealizowanych projektów na szczególną uwagę zasługują programy: Aktywizacja kontaktów gospodarczych pomiędzy Regionem Lubelskim i Okręgiem Wolyńskim, Transgraniczne przedsięwzięcia okołobiznesowe dla sektora małych i średnich przedsiębiorstw, Rozwój transgranicznej wspótpracy gospodarczej w regionie Brześć-Biała Podlaska, Wspótpraca ponad granicami, Zwiększenie absorpcji funduszy europejskich $w$ regionach przygranicznych Polski i Ukrainy, Turystyka - szansa rozwoju obszarów przygranicznych Chetm-Kowel ${ }^{84}$.

Euroregion Niemen utworzony został $\mathrm{w}$ celu podniesienia poziomu życia mieszkańców pogranicza dzięki wykorzystaniu możliwości, które pojawiły się na skutek przemian społecznych, politycznych i gospodarczych i wykorzystaniu położenia obszaru Mazur i Suwalszczyzny. W Euroregionie wprowadzono szereg projektów mających wpłynąć na rozwój gospodarczy regionu. Utworzono Stowarzyszenie Izb Gospodarczych ERN, organizowane są konferencje i targi gospodarcze, trwają pracę nad zagospodarowaniem Kanału Augustowskiego, utworzono Centrum Informacji Turystycznej Euroregionu Niemen ${ }^{85}$.

82 Statut Stowarzyszenia Samorządów Euroregionu Bug, Cele Stowarzyszenia i sposoby ich realizacji, http://euroregionbug.pl/content/view/10/8/ [dostęp 13.06.2015].

83 Związek Transgraniczny Euroregion Bug, Stowarzyszenie Samorządów Euroregionu Bug, Informacje ogólne, http://www.euroregionbug.pl/content/view/12/18/ [dostęp 17.06.2015].

84 Euroregion Bug, Beneficjenci PHARE na terenie Euroregionu Bug, s. 14, http://euroregionbug. $\mathrm{pl} /$ downloads/beneficjenci.doc [dostęp 17.06.2015].

85 Stowarzyszenie Euroregionu Niemen, Początki Euroregionu Niemen, http://www.niemen. org.pl/index.php?option=com_content $\& v i e w=$ category\&layout=blog\&id=2\&ltemid $=4 \& l a$ $\mathrm{ng}=\mathrm{pl}$ [dostęp 17.08.2014]. 
Euroregion Łyna-Ława jest jednym $\mathrm{z}$ najmłodszych euroregionów, powstał w 2003 r. Wśród dotychczas zrealizowanych przedsięwzięć należy wymienić współorganizację Międzynarodowego Spływu Łyną „Stopki-Prawdinsk”, budowę przejścia granicznego dla ruchu turystycznego na Łynie, opracowanie Strategii Euroregionu Łyna-Ława. Euroregion bierze również udział w projekcie Budowa potencjału instytucjonalnego organizacji pozarzadowych Obwodu Kaliningradzkiego do uczestnictwa $w$ polsko-rosyjskiej wspólpracy transgranicznej ${ }^{86}$. W Euroregionie funkcjonuje Specjalna Strefa Ekonomiczna, której celem jest aktywizacja biznesu po obu stronach granicy. Głównym źródłem dochodów mieszkańców Euroregionu Łyna-Ława jest turystyka. Decydującym czynnikiem wpływającym na rozwój turystyki w Euroregionie jest nowoczesna i rozbudowana baza noclegowa (ponad 200 obiektów hotelarskich). Rozwój turystyki z kolei pozwala na rozwój małej i średniej przedsiębiorczości ${ }^{87}$.

W Euroregionie Bałtyk realizowany jest projekt Seagull dla Euroregionu Bałtyk, którego głównym celem jest zbudowanie i rozwinięcie długotrwałej strategii i planu rozwoju dla regionu. Plan ma być podstawą realizacji inwestycji w infrastrukturę oraz środowisko naturalne. Celem projektu ma być zrównoważony i trwały rozwój całego regionu ${ }^{88}$. W Euroregionie realizowane są również projekty BaltNet (rozwój współpracy na rzecz integracji rynków pracy w regionie), DISKE (rozwój innowacyjnych systemów i współpraca MŚP).

\section{Aspekt społeczny}

Euroregion Bug realizuje wiele projektów mających na celu aktywizację i zbliżenie lokalnej ludności po obu stronach granic. Organizowane są wystawy, spotkania kulturalne, artystyczne. Wśród zrealizowanych w Euroregionie projektów wyróżnić można m.in. Transgraniczny sport, kultura i wypoczynek nad Jeziorem Firlej, Festiwal Międzynarodowe Poleskie Lato z Folklorem, Program Edukacyjny Dla Młodzieży w Zakresie Ochrony Dóbr Kultury Euroregionu Bug, Europejskie Centrum Edukacji, Kultura narodów na pradawnym szlaku królewskim Warszawa-Kijów ${ }^{89}$.

W Euroregionie Niemen prowadzone są działania na rzecz nawiązywania partnerskich relacji pomiędzy instytucjami kulturalnymi i samorządowymi. Efektem współpracy euroregionalnej jest utworzenie Instytutu Demokracji Lokalnej Euroregionu i Centrum Koordynacji Przestrzennej Niemen. Działanie Euroregionu

86 Główny Urząd Statystyczny, Euroregiony na granicach Polski. Euroregiony na pograniczu północnym, s. 166, http://www.stat.gov.pl/cps/rde/xbcr/wroc/ASSETS_165-174.pdf [dostęp 17.06.2015].

87 Euroregion Łyna Ława, http://www.powiat-olsztynski.pl/t2/index.php?page=projlyna [dostęp 17.08.2014].

88 Stowarzyszenie Gmin RP Euroregionu Bałtyk, Seagull, http://www.eurobalt.org.pl/index. php [dostęp 17.08.2014].

89 Euroregion Bug, Projekty realizowane w II naborze, http://www.euroregionbug.pl/content/ view/29/3/ [dostęp 18.08.2014]. 
w aspekcie społecznym oparto o organizowanie i upowszechnianie dokonań lokalnych artystów, organizowanie festiwali dotyczących kultury pogranicza i opracowywanie wspólnych wydawnictw popularno-naukowych poświęconych kulturze i społeczności pogranicza ${ }^{90}$.

Aspekt społeczny funkcjonowania Euroregionu Łyna-Ława przejawia się w promowaniu przez Euroregion dorobku kulturalnego narodów. Władze Euroregionu podkreślają konieczność zbliżenia społeczności lokalnych i ich integracji.

Euroregion Bałtyk jest inicjatorem i koordynatorem większości projektów i wydarzeń transgranicznych w Obwodzie Kaliningradzkim. Społeczność lokalna ma możliwość aktywnego uczestnictwa w wydarzeniach kulturalnych, takich jak: Międzynarodowy Konkurs Dzieci i Młodzieży Euroregionu Bałtyk Od morza jesteśmy ${ }^{91}$. W Euroregionie wdrożono projekt dotyczący współpracy i integracji młodzieży Południowego Bałtyku.

\section{Aspekt ochrony środowiska naturalnego}

Jednym ze statutowych celów Euroregionu Bug jest ochrona środowiska naturalnego w dorzeczu Bugu. W Euroregionie udało się zrealizować projekty dotyczące ochrony przyrody, takie jak: Zielona Wyspa (wzmocnienie współpracy pomiędzy Gminą Sułów i Rejonem Maniewicze poprzez promocję działań proekologicznych u partnera zagranicznego), Wspótpraca europejska na rzecz turystyki ekologicznej w Euroregionie Bug, Transgraniczna strategia przeciwpowodziowa $w$ dolinie rzeki Bug.

W Euroregionie Niemen duży nacisk kładzie się na aspekt ochrony środowiska. Priorytetowymi działaniami była budowa zlewni rzek Niemen, wprowadzenie gospodarki odpadami, budowa oczyszczalni ścieków oraz utworzenie transgranicznych obszarów chronionych ${ }^{92}$.

W Euroregionie Puszcza Białowieska znajduje się unikalny kompleks lasów pierwotnych Puszczy Białowieskiej. Zasadniczym celem jest ochrona kompleksu przyrodniczego, a także działania mające na celu racjonalne wykorzystanie istniejących zasobów przyrody ${ }^{93}$.

W Euroregionie Łyna-Ława zasób walorów przyrody jest wyjątkowy, a na jego obszarze funkcjonują liczne rezerwaty przyrody. Celem Euroregionu jest wspólne rozwiązywanie problemów ekologicznych i dbałość o ochronę środowiska natu-

90 Stowarzyszenie Euroregionu Niemen, Poczq̨tki Euroregionu Niemen, http://www.niemen. org.pl/index.php?option=com_content\&view=category\&layout=blog\&id=2\&ltemid=4\&la $\mathrm{ng}=\mathrm{pl}$ [dostęp 07.08.2014].

91 Ramowy Dokument Wymiaru Północnego, „Biuletyn Euroregionu Bałtyk”, nr 4-5/2007, s. 6-7.

92 Stowarzyszenie Euroregionu Niemen, Początki Euroregionu, http://www.niemen.org.pl/, s. 2-5 [dostęp 12.05.2014].

93 Wrota Podlasia, Euroregion Puszcza Białowieska, http://www.wrotapodlasia.pl/pl/region/ wspolpraca_zagraniczna/euroregiony/puszcza_bia\%C5\%82owieska/ [dostęp 14.08.2014]. 
ralnego. Euroregion jest uczestnikiem projektu zagospodarowania zlewni Łyny - Ławy, którego celem jest ochrona zasobów przyrody w dorzeczu tych dwóch rzek.

Jednym z priorytetowych celów Euroregionu Bałtyk jest dbałość o naturalne zasoby przyrody. W tym celu wdrożono szereg projektów i programów, w tym m.in. projekt Moment dotyczący nowoczesnej gospodarki wodnej i Projekt LED, którego celem jest konwersja oświetlenia w miejscach publicznych na nowoczesną i przyjazną środowisku naturalnemu technologię LED.

\subsection{Uwagi końcowe}

W euroregionach, do których należą obszary Polski, wdrażane są strategie na rzecz trwałego i zrównoważonego rozwoju. Wszystkie euroregiony objęte są trzecim celem unijnej polityki regionalnej, a więc mogą korzystać ze wszystkich dostępnych instrumentów finansowych Unii Europejskiej. Zasadność wdrażania koncepcji zrównoważonego rozwoju w euroregionach jest naturalną konsekwencją ewolucji polityki strukturalnej UE. Bliskość geograficzna i relacje społeczno-gospodarcze pomiędzy mieszkańcami bardzo często stanowią element łączący euroregiony. Niosą one za sobą konieczność podejmowania wspólnych działań, wykraczających poza granicę jednego państwa czy regionu. Słuszne jest stwierdzenie, że euroregiony pozytywnie wpływają na rozwój współpracy transgranicznej. Na uwagę zasługuje fakt, że żaden z powołanych na polskich granicach euroregionów nie przestał funkcjonować. Polskie euroregiony mogą stanowić przykład dla nowo tworzonych form sformalizowanej współpracy transgranicznej w Europie Wschodniej i Południowej. Dzięki czemu ich rola w procesie integracji kontynentu europejskiego jest bezsprzeczna, a samo ich funkcjonowanie pobudza lokalne inicjatywy wspierające rozwój przedsiębiorczości, sprzyja aktywizacji społecznej i podejmowaniu działań z zakresu dbania o środowisko naturalne. 



\section{Rozdział 5}

\section{Uwarunkowania wdrażania koncepcji zrównoważonego rozwoju w euroregionach na zachodniej granicy Polski}

\subsection{Uwagi wstępne}

Koncepcja zrównoważonego rozwoju wdrażana jest w euroregionach za pomocą strategii uwzględniających równość pomiędzy wartością gospodarki, społeczeństwa i środowiska naturalnego. Rozwój gospodarczy nie może odbywać się kosztem człowieka i zasobów przyrody. Wdrażanie idei rozwoju zrównoważonego wymaga dużo czasu i uwzględnienia pewnych specyficznych cech charakterystycznych dla danego obszaru. Region transgraniczny położony na zachodniej granicy Polski stanowi ciekawy obszar badawczy. Jego ewolucja od terytorium oddzielającego państwo Wspólnoty z państwem trzecim do pełnoprawnego członka i podmiotu realizacji unijnej polityki spójności stanowi ciekawe studium badawcze poświęcone rozwojowi peryferyjnych obszarów przygranicznych. W rozdziale 5 omówione zostały zagadnienia związane z funkcjonowaniem euroregionów na zachodniej granicy Polski, ich strukturą organizacyjną oraz przedstawiona została analiza sytuacji społecznej, gospodarczej oraz stanu ochrony środowiska na obszarze euroregionów.

\subsection{Euroregiony na pograniczu zachodnim - geneza, struktura}

Geneza tworzenia euroregionów z udziałem Rzeczpospolitej Polskiej sięga początku lat 90. XX w. Na zachodniej granicy Polski utworzony został wówczas Euroregion Neisse-Nisa-Nysa, który stał się prekursorem rozwoju współpracy euroregionalnej w tej części Europy. Euroregiony te tworzone były w celu poprawy 
warunków i poziomu życia miejscowej ludności. Poniżej przedstawione zostaną podstawowe uwarunkowania związane $\mathrm{z}$ funkcjonowaniem euroregionów na zachodnim pograniczu Polski.

Euroregion Pomerania utworzony został 15 grudnia 1995 r. w Szczecinie na skutek porozumienia zawartego pomiędzy jednostkami terytorialnymi Szwecji, Polski i Niemiec. Zgodnie z zawartą umową utworzyły go po stronie niemieckiej cztery powiaty przygraniczne i dwa miasta Meklemburgii-Pomorza Przedniego zrzeszone w Związku Komunalnym Europaregion Pomerania ${ }^{1}$. Stronę szwedzką tworzyły trzydzieści trzy gminy regionu Skania, stanowiące Związek Gmin Skanii. Stronę polską tworzyło Stowarzyszenie Gmin Polskich Euroregionu Pomerania (większość gmin województwa zachodniopomorskiego)². Należy zauważyć, że Komunalny Związek Gmin Skanii był członkiem Euroregionu Pomerania do maja 2013 r. Obecnie w skład Euroregionu Pomerania wchodzą: Stowarzyszenie Gmin Polskich Euroregionu Pomerania (województwo zachodniopomorskie wraz z miastem Szczecin) oraz Komunalny Związek Europaregion Pomerania (pięć powiatów z Brandenburgii i Meklemburgii-Pomorza Przedniego)³.

Tabela 5.1. Euroregion Pomerania - podstawowe informacje

\begin{tabular}{|c|c|c|c|}
\hline Regiony tworzące & Powierzchnia & Ludność (2010 r.) & Główne miasta \\
\hline $\begin{array}{c}\text { Województwo zachod- } \\
\text { niopomorskie }\end{array}$ & $8791 \mathrm{~km}^{2}$ & $1,69 \mathrm{mln}$ & Szczecin, Świnoujście \\
\hline $\begin{array}{c}\text { Mecklenburg Vorpom- } \\
\text { mern Brandenburg }\end{array}$ & $11317 \mathrm{~km}^{2}$ & $0,98 \mathrm{mln}$ & $\begin{array}{c}\text { Locknitz, Bernau, } \\
\text { Neubranenburg }\end{array}$ \\
\hline Skane (do maja $2013 \mathrm{r}$.) & $11000 \mathrm{~km}^{2}$ & $1,20 \mathrm{mln}$ & Malmö, Lund, Landskrona \\
\hline
\end{tabular}

Źródło: opracowanie własne na podstawie: H. Rasz, Euroregiony na granicach Polski, Informacja nr 686, http://biurose.sejm.gov.pl/teksty/i-686.htp [dostęp 18.07.2015].

Nazwa Euroregionu oznacza kraj nad morzem, a u podstaw współpracy leży poczucie wspólnej tożsamości i położenie nad Bałtykiem. Euroregion Pomerania do maja 2013 r. zajmował powierzchnię $31198 \mathrm{~km}^{2}$, po odłączeniu gmin szwedzkich - $20198 \mathrm{~km}^{2}$. Największy jego obszar położony jest po stronie niemieckiej natomiast najmniejszy po stronie polskiej. Zgodnie z danymi z 2010 r. Euroregion zamieszkiwało około 3870 tys. mieszkańców, najwięcej w szwedzkiej części euroregionu, najmniejsze zaludnienie występuje w części polskiej. Do najważniejszych miast Euroregionu należą Szczecin, Świnoujście i Neubrandenburg. Niewąt-

1 M. Perkowski, Współpraca transgraniczna. Aspekty prawno-ekonomiczne, Fundacja Prawo i Partnerstwo, Białystok 2010, s. 4-18.

2 Stowarzyszenie Gmin Polskich Euroregionu Pomerania, Powstanie i historia Euroregionu Pomerania, http://www.pomerania.org.pl/stowarzyszeniea4.php [dostęp 14.04.2015].

3 http://www.pomerania.net/main.cfm?l=pl\&rubrik=5\&th=32 [dostęp 10.08.2014]. 
pliwie wystąpienie z Euroregionu Pomerania regionu Skane wpłynęło na znaczne zmniejszenie liczby ludności zamieszkującej obszar współpracy transgranicznej. Strukturę organizacyjną Euroregionu Pomerania tworzą: Rada Euroregionu (po 12 członków z każdej ze stron), Prezydium Euroregionu (po jednym przedstawicielu każdej ze stron) oraz Sekretariat z siedzibą w Szczecinie ${ }^{4}$.

Euroregion Pro Europa Viadrina powstał w 1993 r. Obejmuje on obszar trzydziestu trzech polskich gmin $\mathrm{z}$ województw: zachodniopomorskiego i lubuskiego oraz jednego miasta wydzielonego i dwóch powiatów z landu Brandenburgia. W skład Euroregionu wchodzą: Stowarzyszenie Gmin Polskich Euroregionu Pro Europa Viadrina oraz Stowarzyszenie Środkowa Odra (niemieckie miasta i powiaty - Frankfurt nad Odrą i powiaty Märkisch Oderland i Oder-Spree). Euroregion Pro Europa Viadrina zajmuje łączną powierzchnię $11645 \mathrm{~km}^{2}$, a jego obszar zamieszkuje blisko 818 tys. mieszkańców. Powierzchnia polskiej części Euroregionu jest 1,4 razy większa od niemieckiej. Natomiast liczba ludności zamieszkałej po obu stronach granicy jest na podobnym poziomie. Strukturę organizacyjną tworzą: Rada Euroregionu (po 10 członków ze strony polskiej i niemieckiej), Prezydium Euroregionu (po 2 członków z każdej ze stron, z których na kadencję dwuletnią wybierany jest Prezydent Euroregionu), Sekretariat Euroregionu (tworzą go dwa biura: w Gorzowie Wielkopolskim i Frankfurcie nad Odrą), Grupy Robocze Projektmanagement, Grupa Robocza ds. Turystyki i Grupa Robocza ds. Gospodarki ${ }^{5}$.

Tabela 5.2. Euroregion Pro Europa Viadrina

\begin{tabular}{|c|c|c|c|}
\hline Regiony tworzące & Powierzchnia & Ludność (2010 r.) & Główne miasta \\
\hline $\begin{array}{c}\text { Północna czéść } \\
\text { woj. lubuskiego }\end{array}$ & $7128 \mathrm{~km}^{2}$ & $0,38 \mathrm{mln}$ & $\begin{array}{c}\text { Gorzów Wielkopolski, } \\
\text { Kostrzyn, Słubice }\end{array}$ \\
\hline $\begin{array}{c}1 \text { miasto wydzielone } \\
\text { i } 2 \text { powiaty z landu } \\
\text { Brandenburgia }\end{array}$ & $4517 \mathrm{~km}^{2}$ & $0,44 \mathrm{mln}$ & $\begin{array}{c}\text { Frankfurt, Seelow, } \\
\text { Beeskow }\end{array}$ \\
\hline
\end{tabular}

Źródło: opracowanie własne na podstawie: H. Rasz, Euroregiony na granicach Polski, Informacja nr 686, http://biurose.sejm.gov.pl/teksty/i-686.htp [dostęp 14.04.2015].

W 1993 r. utworzono Euroregion Sprewa-Nysa-Bóbr, w którym współpracują polskie gminy ze Stowarzyszenia Gmin RP Euroregion Sprewa-Nysa-Bóbr oraz miasta i powiaty Republiki Federalnej Niemiec ${ }^{6}$. Euroregion Sprewa-Nysa-Bóbr

4 Stowarzyszenie Gmin Polskich Euroregionu Pomerania, Władze Euroregionu Pomerania, http://www.pomerania.org.pl/stowarzyszenieb4.php [dostęp 17.09.2014].

5 Stowarzyszenie Gmin Polskich Euroregionu „Pro Europa Viadrina”, Struktura i Schemat organizacyjny, http://euroregion-viadrina.pl/content/struktura-i-schemat-organizacyjny-0 [dostęp 12.04.2015].

6 Umowa o utworzeniu Euroregionu Sprewa-Nysa-Bóbr zawarta między stowarzyszeniem gmin Rzeczpospolitej Polskiej Euroregion Sprewa-Nysa-Bóbr a stowarzyszeniem 
obejmuje część obszaru województwa lubuskiego (50 gmin), województwa wielkopolskiego (1 gmina), zaś po niemieckiej stronie granicy w skład Euroregionu wchodzi 1 miasto wydzielone i 1 powiat $\mathrm{z}$ landu Brandenburgia. Całkowita powierzchnia Euroregionu wynosi $9656 \mathrm{~km}^{2}$, przy czym główny jego obszar położony jest po stronie polskiej (część polska Euroregionu jest ponad czterokrotnie większa od niemieckiej). Po stronie polskiej mieszka $0,63 \mathrm{mln}$ osób, natomiast po stronie niemieckiej - 0,23 mln. Strukturę organizacyjną Euroregionu tworzą: Rada Euroregionu (Konferencja Stowarzyszenia Gmin RP i Zgromadzenie Członków Stowarzyszenia Niemieckiego), Prezydium (konwent Stowarzyszenia Gmin RP i Zarząd Stowarzyszenia Miast i Powiatów RFN) oraz Sekretariat ${ }^{7}$.

Tabela 5.3. Euroregion Sprewa-Nysa-Bóbr

\begin{tabular}{|c|c|c|c|}
\hline Regiony tworzące & Powierzchnia & Ludność (2010 r.) & Główne miasta \\
\hline $\begin{array}{c}\text { Województwo lubuskie } \\
\text { (50 gmin), województwo } \\
\text { wielkopolskie (1 gmina) }\end{array}$ & $7844 \mathrm{~km}^{2}$ & $0,63 \mathrm{mln}$ & Zielona Góra, Żary \\
\hline $\begin{array}{c}1 \text { miasto wydzielone i 1 po- } \\
\text { wiat z landu Brandenburgia }\end{array}$ & $1812 \mathrm{~km}^{2}$ & $0,23 \mathrm{mln}$ & Cottbus, Guben \\
\hline
\end{tabular}

Źródło: opracowanie własne na podstawie: H. Rasz, Euroregiony na granicach Polski, Informacja nr 686, http://biurose.sejm.gov.pl/teksty/i-686.htp [dostęp 15.05.2015].

Tabela 5.4. Euroregion Neisse-Nisa-Nysa

\begin{tabular}{|c|c|c|c|}
\hline Regiony tworzące & Powierzchnia & Ludność (2010 r.) & Główne miasta \\
\hline $\begin{array}{c}\text { Saksonia (powiaty Bautzen } \\
\text { i Görlitz) }\end{array}$ & 4,5 tys. $\mathrm{km}^{2}$ & $0,6 \mathrm{mln}$ & Gorlitz \\
\hline $\begin{array}{c}\text { Województwo dolnośląskie } \\
\text { (8 powiatów) }\end{array}$ & 5,6 tys. $\mathrm{km}^{2}$ & $0,57 \mathrm{mln}$ & $\begin{array}{c}\text { Jelenia Góra, } \\
\text { Zgorzelec }\end{array}$ \\
\hline Liberecky kraj & 3,2, tys. $\mathrm{km}^{2}$ & $0,44 \mathrm{mln}$ & Liberec \\
\hline
\end{tabular}

Źródło: Urząd Statystyczny we Wrocławiu, Czeski Urząd Statystyczny, Przedstawicielstwo Okręgowe w Libercu, Krajowy Urząd Statystyczny Wolnego Państwa Saksonii w Kamenz, Stowarzyszenie Gmin Polskich Euroregionu, Nysa Euroregion Neisse-Nisa-Nysa 2008, Kraków-Liberec 2008, s. 7.

Euroregion Neisse-Nisa-Nysa powstał w 1991 r. w wyniku podpisania wspólnej deklaracji o współpracy pomiędzy samorządami polskimi, niemieckimi i czeskimi. Obejmuje on obszar wschodniej Saksonii (powiaty Bautzen i Görlitz) o powierzchni 4,5 tys. $\mathrm{km}^{2}$, południowej części województwa dolnośląskiego o po-

Euroregion Sprewa-Nysa-Bóbr, http://pliki.euroregion-snb.pl/umowa_snb.pdf [dostęp 15.04.2015].

7 Euroregion Sprewa-Nysa-Bóbr, Struktura organizacyjna, http://euroregion-snb.pl/o_nas/ wladze [dostęp 15.04.2014]. 
wierzchni 5,6 tys. $\mathrm{km}^{2}$ oraz czeską część o powierzchni 3,2 tys. $\mathrm{km}^{2}$. Całkowita powierzchnia Euroregionu wynosi 13,3 tys. $\mathrm{km}^{2}$. Najbardziej zaludnioną częścią jest obszar niemieckich powiatów Bautzen i Görlitz, który zamieszkiwany jest przez 0,6 mln mieszkańców, najmniejsze zaludnienie jest po stronie czeskiej, gdzie mieszka około 0,4 mln mieszkańców. Całkowita ludność Euroregionu wynosi około 1,6 mln mieszkańców.

Euroregion jest wspólnotą trzech krajowych stowarzyszeń, będących autonomicznymi podmiotami prawnymi posiadającymi wspólne cele przedstawione w dokumencie Ramowe Porozumienie Euroregionu Neisse-Nisa-Nysa ${ }^{8}$. Strukturę organizacyjną Euroregionu tworzą następujące organy: Rada Euroregionu (w jej skład wchodzą dziesięcioosobowe przedstawicielstwa każdej z trzech stron), Prezydium (w którego skład wchodzą prezydenci strony polskiej, czeskiej i niemieckiej), Sekretariat oraz Grupy robocze ${ }^{9}$.

\subsection{Diagnoza sytuacji gospodarczej, społecznej i ochrony środowiska naturalnego}

Regiony Polski zachodniej posiadają niższe wskaźniki rozwoju społeczno-gospodarczego w porównaniu z przygranicznymi landami niemieckimi i regionem czeskim. Kluczowe dla rozwoju euroregionów na polskim pograniczu zachodnim jest bliskie sąsiedztwo Niemiec, w tym Berlina oraz efektywne wykorzystanie bogatych przyrodniczo obszarów w dorzeczu Odry pomiędzy Morzem Bałtyckim a Sudetami. W sensie gospodarczym konieczne jest wykorzystanie potencjału endogenicznego i nawiązywanie stosunków gospodarczych pomiędzy Polską, Niemcami i Czechami.

\subsubsection{Położenie euroregionów}

Euroregiony położone są wzdłuż dorzecza Odry i rozciągają się na obszarze od Morza Bałtyckiego do Sudetów, obejmują obszar pięciu polskich województw (zachodniopomorskiego, wielkopolskiego, lubuskiego, opolskiego i dolnośląskiego), trzech wschodnich landów Republiki Federalnej Niemiec (Brandenburgia, Meklemburgia-Pomorze Przednie i Saksonia) oraz Czech. Dokonując analizy położenia geograficznego euroregionów, należy zauważyć, że poziom rozwoju

\footnotetext{
8 Urząd Statystyczny we Wrocławiu, Czeski Urząd Statystyczny, Krajowy Urząd Statystyczny w Saksonii, Rocznik Euroregionu Nysa 2011, Wrocław-Liberec-Kamenz 2011, s. 20.

9 Ibidem, s. 20.
} 
gospodarczego wschodnich landów niemieckich wchodzących w ich skład jest zdecydowanie niższy w porównaniu ze średnią dla Niemiec. Równie niepokojące są negatywne wskaźniki demograficzne dla obszarów Brandenburgii i Meklemburgii. Niewątpliwie wartością, która może zaważyć na rozwoju euroregionów na zachodniej granicy jest bliskość Berlina. Należy odnotować, że w skład Euroregionu Neisse-Nisa-Nysa wchodzą powiaty czeskie, które charakteryzują się niższym poziomem rozwoju społeczno-gospodarczego w porównaniu ze średnią dla Czech. Od wschodniej strony euroregiony graniczą z województwami: kujawsko-pomorskim, pomorskim, łódzkim, śląskim ${ }^{10}$. Położenie geograficzne, w tym przede wszystkim bliskość Niemiec, stwarza świetne warunki dla rozwoju współpracy i nawiązywania pozytywnych relacji sąsiedzkich.

\subsection{2. Środowisko naturalne}

Zrównoważony rozwój ekologiczny w euroregionach na zachodniej granicy Polski dotyczy zwykle obszaru przyrodniczego dorzecza Odry, Zatoki Szczecińskiej i pasa wybrzeża Morza Bałtyckiego. Niemal całe dorzecze Odry objęte jest programem Natura $2000^{11}$. Bogactwo przyrodnicze dorzecza sprawia, że jest ono jednym z głównych korytarzy ekologicznych w Europie. W dolinie Odry zachowane są pozostałości siedlisk zalewowych: starorzeczy, mokradeł, lasów łęgowych ${ }^{12}$. Na przestrzeni ostatnich lat podjęto szereg inwestycji strukturalnych mających na celu rozwój i urbanizację dorzecza Odry. Konieczne jest podejmowanie działań w skali lokalnej, regionalnej i ponadregionalnej w celu ochrony zasobów przyrody i tworzenia korytarzy ekologicznych umożliwiających migrację organizmów i zwierząt nieprzyzwyczajonych do życia poza korytarzem ${ }^{13}$.

Różnorodność poszczególnych fragmentów krajobrazu i bogactwo zasobów przyrody na terytorium Euroregionu Pomerania spowodowało, że występuje w nim wiele obszarów chronionych prawnie, uznanych w układzie ponadregionalnym. W Euroregionie znajdują się następujące wieloobszarowe tereny chronione ${ }^{14}$ :

10 http://polskazachodnia2020.pl/attachments/article/14/Wykorzystanie\%20po\%C5\%82o\% C5\%BCenia\%20przygranicznego....J.\%20Zaleski.pdf [dostęp 10.08.2014].

11 Ministerstwo Środowiska, Raport dla Obszaru Dorzecza Odry z realizacji art. 5 i 6, zał. II, III, IV Ramowej Dyrektywy Wodnej 2000/60/WE, Warszawa 2005, s. 8-11.

12 A. Drabiński, P. Nieznański, Odrzańska Droga Wodna a środowisko przyrodnicze. Studia nad rozwojem Dolnego Śląska, Wrocław 2010, s. 33-35.

13 Z. Mogiła, J. Zaleski, M. Zathey, Wykorzystanie przygranicznego położenia terenów znajdujacych się w zachodniej części Polski dla rozwoju społeczno-gospodarczego, Ekspertyza przygotowana na zamówienie Ministerstwa Rozwoju Regionalnego w ramach prac nad Strategią Rozwoju Polski Zachodniej, Wrocław 2011, s. 32-35.

14 Euroregion Pomerania, Koncepcja Rozwoju i Działania na lata 2000-2006. 
- parki narodowe: Drawieński Park Narodowy, Woliński Park Narodowy, Dolina Dolnej Odry, Krajobraz Zatokowy Pomorza Przedniego, Krajobraz Zatokowy Pomorza Przedniego,

- rezerwaty biosfery: Południowo-Wschodnia Rugia, Schorfheide-Chorin, Fulltofta, Glumslövs, Järavallen, Häckeberga, Tal Klingavälsåns w Lund, Skrylle, Verkeån, Hammars backar-Kåsebergaåsen, Sandhammaren,

- parki krajobrazowe: Drawski Park Krajobrazowy, Cedyński Park Krajobrazowy, Park Krajobrazowy Barlinecko-Gorzowski, Iński Park Krajobrazowy, Szczeciński Park Krajobrazowy, Park Krajobrazowy Doliny Dolnej, Park Krajobrazowy Ujście Warty,

- parki przyrody: Uznam, Rugia, Szwajcaria Meklemburska i jezioro Kummerow, Nad Zalewem Szczecińskim, Jeziora Uckermark, Barnim.

Najważniejszym celem tworzenia terenów chronionych jest zrównoważony rozwój euroregionalny oraz zachowanie biologicznej różnorodności obszarów cennych przyrodniczo. Euroregion Pomerania zgodnie z prawem ochrony środowiska w Unii Europejskiej wyznaczył specjalne obszary europejskiej sieci Natura 2000 składającej się z dwóch dyrektyw: siedliskowej oraz ptasiej (obszary ochrony ptaków) ${ }^{15}$.

W Euroregionie Pro Europa Viadrina ze względu na różnorodność krajobrazu oraz rzeźbę geomorficzną duża część terytorium uznana została za obszary chronione. Na terenie Euroregionu występują: Park Narodowy i Park Krajobrazowy Ujście Warty, Drawieński Park Narodowy, Barlinecko-Gorzowski Park Krajobrazowy, Krzesiński Park Krajobrazowy, Łagowsko-Sulęciński Park Krajobrazowy, Pszczewski Park Krajobrazowy, Park Przyrodniczy Dahme-Heideseen, Park Przyrodniczy Szwajcaria Marchijska, Park Przyrodniczy Dolina Schlaube. Całkowity obszar chroniony w Euroregionie Pro Europa Viadrina stanowi około 40\% jego powierzchni.

W Euroregionie Sprewa-Nysa-Bóbr prawie 30\% terytorium objęte zostało ochroną. Najważniejszymi parkami są Rezerwat Biosferyczny Spreewald, Park Przyrodniczy Schlaubetal, Polsko-Niemiecki Park Przyrodniczy Łuk Mużakowski-Muskauer-Faltenbogen, Rezerwat Przyrody Lieberoser Endmoräne, Łagowski, Gryżyński. W Euroregionie występuje duża ilość chronionych gatunków zwierząt i roślin (np. orzech wodny, orchidee, bocian czarny, wydra). Charakterystycznym dla niemieckiej części Euroregionu jest fakt, że obszar ten położony jest w strefie leja kopalnianego, dlatego brakuje odpowiedniej ilości wody gruntowej (wody Nysy i Szprewy mają obecnie drugą klasę czystości). W Euroregionie znajduje się ponad 200 jezior, a lasy zajmują ponad 50\% powierzchni, w tym 200 tys. ha lasów objęte jest ochroną.

15 Dyrektywa 92/43/EWG Rady z 21 maja 1992 r. o obszarach FFH, Dyrektywa siedliskowa 79/409/EWG Rady z 2 kwietnia 1979 r. (dyrektywa ptasia). 
Euroregion Neisse-Nisa-Nysa w latach 80 . XX w. był jednym z najbardziej zanieczyszczonych obszarów w Europie i wchodził w skład tzw. Czarnego Trójkąta. Dzięki podjętym działaniom udało się w znacznym stopniu poprawić stan środowiska naturalnego. Na terenie Euroregionu znajduje się:

- w czeskiej części ERN: 5 parków krajobrazowych, 8 narodowych pomników przyrody, 8 narodowych rezerwatów przyrody, 37 rezerwatów przyrody oraz 63 pomniki przyrody,

- w polskiej części ERN: 1 park narodowy (Karkonoski Park Narodowy), 7 parków krajobrazowych (w tym: Park Krajobrazowy Góry Izerskie), 17 rezerwatów przyrody, 8 rezerwatów krajobrazowych i 639 pomników przyrody,

- w niemieckiej części ERN (Saksonia): 1 park narodowy, 1 rezerwat biosfery, 3 parki przyrodnicze, 215 rezerwatów przyrody, 178 obszarów chronionych (na szczególną uwagę zasługują Łużycki Park Głazów Narzutowych w Nochten, Park Rododendronów w Kromlau) ${ }^{16}$.

\subsubsection{Potencjał ludzki i warunki życia mieszkańców}

Potencjał ludzki jest kluczowym elementem poziomu konkurencyjności regionów i budowania gospodarki opartej na wiedzy. Dobrze wykształcone społeczeństwo pozwala na szybki transfer wiedzy i technologii. Znaczenie kapitału ludzkiego dla rozwoju regionalnego dostrzeżone zostało przez władze Unii Europejskiej oraz uwzględnione w celach polityki regionalnej ${ }^{17}$. Rozwój produkcji i jej przestrzenna alokacja uwarunkowana jest posiadaniem odpowiedniej grupy specjalistów z różnych dziedzin gospodarki umożliwiających wdrażanie innowacji i nowych technologii ${ }^{18}$. Korzyści płynące $\mathrm{z}$ kapitału ludzkiego powodują, że stanowi on główny czynnik produkcji zapewniający zrównoważony rozwój ${ }^{19}$.

Zmiany demograficzne w Europie polegające na przejściu z wysokiego wskaźnika urodzeń i zgonów do sytuacji, w której niskiemu poziomowi urodzeń towarzyszy duża liczba zgonów są niekorzystne z punktu widzenia rozwoju społe-

16 Euroregion Neisse-Nisa-Nysa, Strategia rozwoju Euroregionu Neisse-Nisa-Nysa na lata 2014-2020, http://www.jawor.pl/pliki/8/strategia-rozwoju-euroregionu-nysa-2014-2020pl.pdf, s. 46-47 [dostęp 06.09.2015].

17 A. Golejewska, Kapitał ludzki, innowacje i instytucje a konkurencyjność regionów Europy Środkowej Wschodniej, „Human capital, innovation and institutions versus the competitiveness of regions in Central and Eastern Europe", nr 49/2012, s. 29-30.

18 P.M. Romer, Endogenous Technological Change, "Journal of Political Economy", no 98/1990, s. 71-102.

19 R.E. Lucas, On the Mechanics of Economic Development, „Journal of Monetary Economics”, no $1(22) / 1988$, s. 33-42. 
czeństwa ${ }^{20}$. Na obszarach współpracy transgranicznej na pograniczu zachodnim zachowana jest podobna tendencja ${ }^{21}$.

W Euroregionie Pomerania od roku 2003 obserwuje się spadek liczby ludności. Co prawda w całym badanym i prognozowanym (do 2020 r.) okresie spadek ludności nie jest duży, ale stały. Najbardziej zaludnioną częścią jest obszar pogranicza polskiego, natomiast, najmniej ludności jest po stronie niemieckiej.

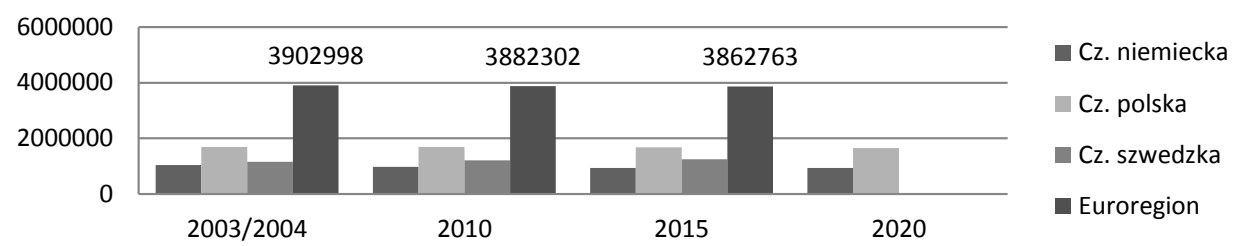

Wykres 5.1. Liczba ludności w Euroregionie Pomerania

Źródło: opracowanie własne na podstawie danych z Sekretariatu Euroregionu Pomerania, http//pomerania.org [dostęp 12.05.2015].

W niemieckiej części Euroregionu w okresie pomiędzy 2003 a 2015 r. nastąpił spadek ludności o 108693 mieszkańców, co stanowi 10\% populacji. Natomiast w części polskiej w analogicznym okresie liczba mieszkańców zmniejszyła się o 20300 mieszkańców. W części szwedzkiej Euroregionu liczba mieszkańców wzrosła o 88757 mieszkańców (część szwedzka odłączyła się od regionu w maju 2013 r.).

Niekorzystne procesy demograficzne są również zauważalne $\mathrm{w}$ analizie grup wiekowych w Euroregionie Pomerania. Zgodnie z danymi zawartymi w Transgranicznej koncepcji rozwoju i działania Euroregionu Pomerania na lata 2014-2020 do 2030 r. odsetek osób starszych będzie rósł. Przy czym szczególnie widoczne będzie to w niemieckiej części Euroregionu (tabela 5.5). Główną grupę ludności w Euroregionie Pomerania stanowią osoby pomiędzy 15-65 rokiem życia. Zauważalny jednak jest trend spadkowy w tej grupie wiekowej. Można również zauważyć, że wzrasta liczba osób powyżej 65. roku życia. Widoczne jest to szczególnie w niemieckiej części Euroregionu.

Zgodnie z prognozą w okresie 2010-2030 liczba osób powyżej 65. roku życia w niemieckiej części Euroregionu wzrośnie o 17,1\%, w polskiej o 10,5\%. Jednocześnie liczba osób poniżej 15. roku nie przekracza w analizowanym okresie 15,3\%.

20 A. Weinkauf, M. Kajcińska, Diagnoza demograficzno-epidemiologiczna dotycząca osób starszych w Polsce i na Mazowszu w latach 2004- 2005, Warszawa 2006, s. 15-26.

21 Z. Woźniak-Hasik, Trendy demograficzne dotyczące wieku w UE. Materiały szkoleniowe, Warszawa 2007, s. 2. 
Tabela 5.5. Prognoza liczby ludności wg grup wiekowych w Euroregionie Pomerania

\begin{tabular}{|c|c|c|c|c|}
\hline \multirow{2}{*}{ Wiek } & $\begin{array}{c}\text { Części } \\
\text { euroregionu }\end{array}$ & 2010 & 2020 & 2030 \\
\hline \multirow{2}{*}{ Poniżej 15 lat } & polska & $14,9 \%$ & $15,3 \%$ & $13,4 \%$ \\
\cline { 2 - 5 } & niemiecka & $11,3 \%$ & $11,4 \%$ & $11,8 \%$ \\
\hline \multirow{2}{*}{$15-65$ lat } & polska & $72,9 \%$ & $66,2 \%$ & $64,0 \%$ \\
\cline { 2 - 5 } & niemiecka & $66,2 \%$ & $62,7 \%$ & $48,7 \%$ \\
\hline \multirow{2}{*}{ Powyżej 65 lat } & polska & $12,2 \%$ & $18,5 \%$ & $22,7 \%$ \\
\cline { 2 - 5 } & niemiecka & $22,5 \%$ & $25,9 \%$ & $39,6 \%$ \\
\hline
\end{tabular}

Źródło: opracowanie własne na podstawie: Transgraniczna koncepcja rozwoju i działania Euroregionu Pomerania na lata 2014-2020, http://www.pomerania.org.pl/site/aktualizacja-transgra nicznej-koncepcji-rozwoju-i-dzialania-e/179, s. 6 [dostęp 12.09.2015].

W Euroregionie Pro Europa Viadrina w latach 2004-2011 liczba ludności spadła z poziomu 823827 do poziomu $819377^{22}$.

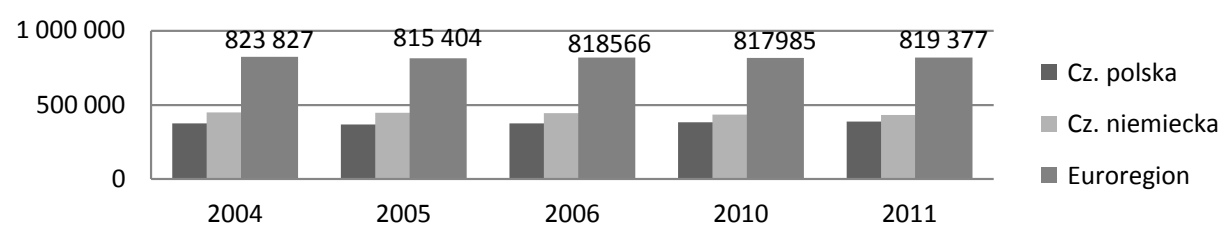

Wykres 5.2. Liczba ludności w Euroregionie Pro Europa Viadrina

Źródło: opracowanie własne na podstawie danych statystycznych z Sekretariatu Euroregionu Pro Europa Viadrina.

Jest to rezultatem spadku liczby ludności w części niemieckiej Euroregionu, gdzie na przestrzeni badanego okresu liczba ludności obniżyła się o 16901 osób. Natomiast w części polskiej miał miejsce wzrost liczby ludności z 374453 do 386 904. Zgodnie z prognozą na rok 2030 w Euroregionie Pro Europa Viadrina liczba ludności spadnie poniżej 750000 mieszkańców ${ }^{23}$.

W Euroregionie Pro Europa Viadrina struktura ludności jest charakterystyczna dla regionów europejskich. Procentowy udział osób starszych jest również zdecydowanie wyższy. Znamiene jest, że na przestrzeni lat 2000-2011 udział osób

22 Statystyka liczby ludności w Euroregionie Pro Europa Viadrina uwzględniająca poszczególne krajowe części euroregionu obejmuje okres do 2011 r., wg. stanu na maj 2015 r.

23 Euroregion Pro Europa Viadrina, Koncepcja Rozwoju i Działania Euroregionu Pro Europa Viadrina, Gorzów Wielkopolski-Frankfurt 2014, s. 19. 
powyżej 65. roku życia wzrósł o 5,6\% z poziomu 12,5 do 18,1\%, a osób poniżej 15 . roku życia spadł z poziomu 16,3 do 15,7\%. Zgodnie z prognozą w 2030 r. liczba osób starszych wzrośnie w porównaniu z rokiem bazowym o 22,6\%.

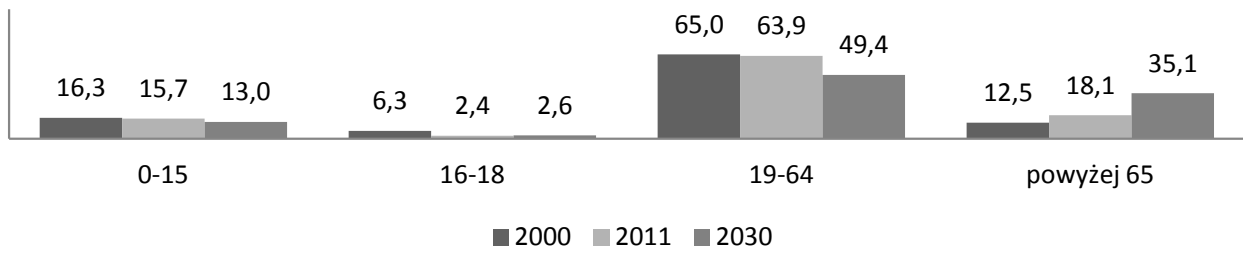

Wykres 5.3. Procentowy udział grup wiekowych w Euroregionie Pro Europa Viadrina Źródło: opracowanie własne na podstawie danych statystycznych z Sekretariatu Euroregionu Pro Europa Viadrina.

W Euroregionie Sprewa-Nysa-Bóbr zmiany demograficzne również nie są korzystne. Zarówno w polskiej, jak i w niemieckiej części Euroregionu liczba ludności spada. W 2000 r. liczba ludności wynosiła 916 154, natomiast w 2010 r. - 856240. Prognoza wskazuje, że w 2030 r. liczba ludności w Euroregionie wyniesie 794 491, zatem w całym analizowanym okresie nastąpi spadek ludności o 13,3\%.

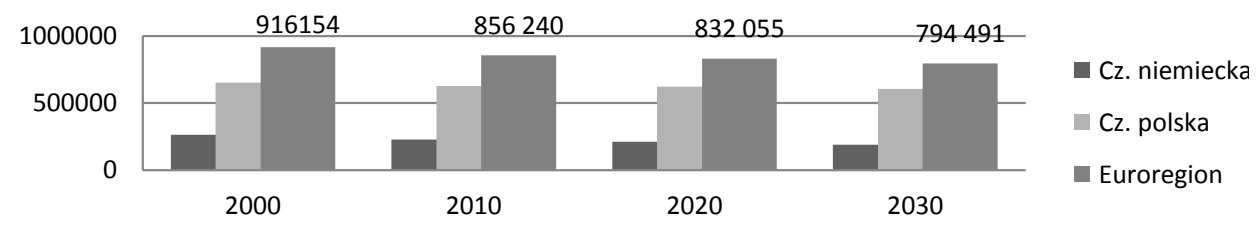

Wykres 5.4. Liczba ludności w Euroregionie Sprewa-Nysa-Bóbr

Źródło: opracowanie własne na podstawie http://euroregionsnb.pl/media/dokumenty/Plan_ rozwoju_i_dzia_ania.pdf oraz http://euroregionsnb.pl/media/dokumenty/Ogolne/plan_rozwo ju_i_dzialania_euroregionu_sprewa_nysa_bobr.pdf [dostęp 17.03.2015].

Największy procentowy udział w grupach ludności przypada na osoby w wieku 15-65 lat (powyżej 70\%). Pozostałe dwie grupy wiekowe ludności poniżej 15. roku i powyżej 65. roku życia stanowią po 15\% ogółu ludności zamieszkującej Euroregion $^{24}$.

24 Dane statystyczne uwzględniające udział grup ludności w Euroregionie Sprewa-Nysa-Bóbr obejmują okres do 2010, wg stanu na maj 2015 r. 


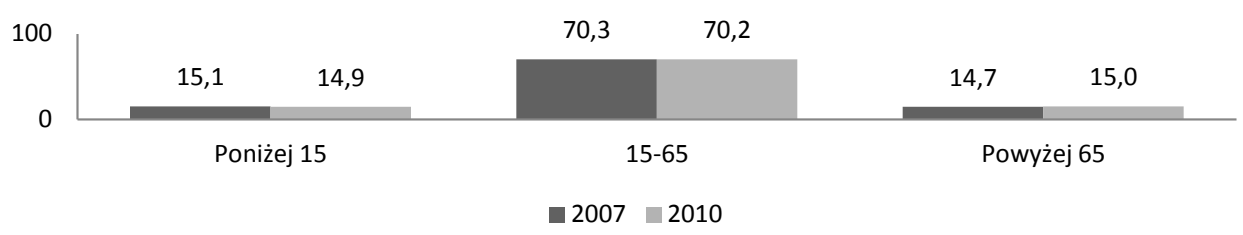

Wykres 5.5. Procentowy udział grup wiekowych w Euroregionie Sprewa-Nysa-Bóbr Źródło: opracowanie własne na podstawie http://euroregion snb.pl/media/dokumenty/Plan_ rozwoju_i_dzia_ania.pdf, s. 37 [dostęp 01.01.2015].

W Euroregionie Neisse-Nisa-Nysa liczba ludności również zmniejszy się z poziomu 1769849 w 1991 r. do prognozowanego poziomu 1432400 w 2025 r., a więc o 337449 . W polskiej części Euroregionu liczba ludności obniży się z poziomu 604372 do 487 300, a w części niemieckiej z 739518 do 505 600. Jednocześnie zgodnie z prognozą w części czeskiej Euroregionu liczba ludności będzie wzrastała z poziomu 425959 w $1991 \mathrm{r}$. do $439500 \mathrm{w} 2025 \mathrm{r}$.

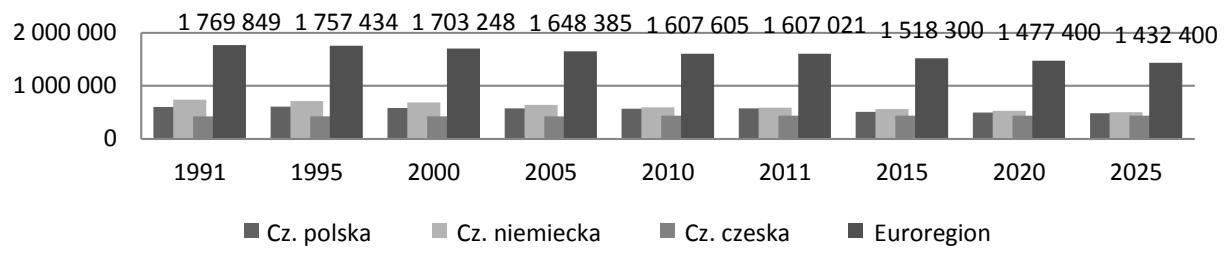

Wykres 5.6. Euroregion Neisse-Nisa-Nysa

Źródło: opracowanie własne na podstawie bazy danych z Sekreatriatu Euroregionu Neisse -Nisa-Nysa.

W Euroregionie Neisse-Nisa-Nisa główną grupę wiekową stanowią osoby starsze. Począwszy od 2000 r. wzrasta liczba osób powyżej 65. roku życia z poziomu $20,5 \%$ do poziomu $30,6 \%$.

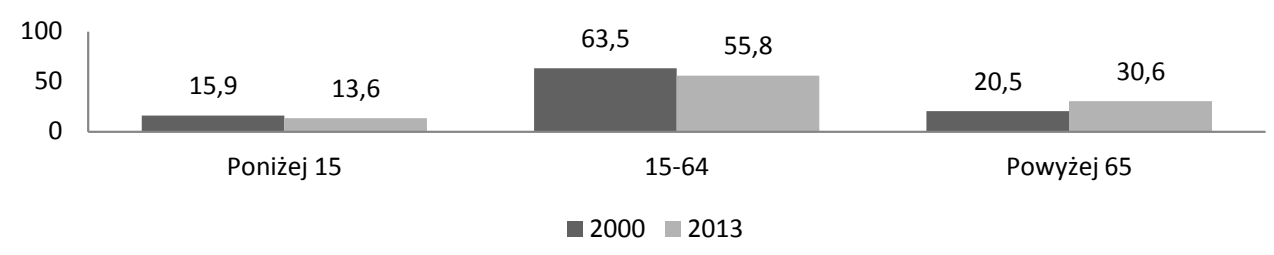

Wykres 5.7. Procentowy udział grup ludnościowych w Euroregionie Neisse-Nisa-Nysa

Źródło: opracowanie własne na podstawie GUS Wrocław, Powiaty w Euroregionie Nysa 2014, http://wroclaw.stat.gov.pl/publikacje-i-foldery/inne-opracowania/powiaty-w-euroregionie-ny sa-2014,4,3.html, s. 9 [dostęp 15.10.2015]. 
Jednocześnie w grupie wiekowej pomiędzy 15 a 64 rokiem życia procentowy udział ludności spada. Można również zauważyć niewielki spadek wśród najmłodszych mieszkańców do 15. roku życia, gdzie procentowy udział spada z poziomu 15,9 do $13,6 \%$.

\section{Analiza poziomu wykształcenia}

Niezwykle ważnym wyznacznikiem potencjału mieszkańców jest poziom ich wykształcenia. Analizując poszczególne euroregiony pod kątem liczby osób posiadających wykształcenie średnie lub wyższe, można zauważyć, że sytuacja demograficzna znajduje swoje odzwierciedlenie w liczbie studentów.

Liczba osób posiadających minimum średnie wykształcenie w Euroregionie Pomerania spada (z 61 do 58\%). Procentowo największą liczbę wśród studentów Euroregionu Pomerania stanowią studenci niemieccy. Na przestrzeni lat 2001 -2014 procentowy udział studentów z Polski w całkowitej liczbie studentów w Euroregionie wzrasta, natomiast udział studentów niemieckich spada.

Tabela 5.6. Wybrane dane o edukacji w Euroregionie Pomerania

\begin{tabular}{|c|c|c|c|c|c|c|c|}
\hline \multirow[t]{2}{*}{ Lata } & \multicolumn{3}{|c|}{$\begin{array}{c}\text { Udział studentów } \\
\text { w poszczególnych częściach } \\
\text { do całkowitej liczby studentów } \\
\text { euroregionu }\end{array}$} & \multicolumn{4}{|c|}{$\begin{array}{l}\text { Osoby z minimum średnim wykształceniem (\%) } \\
\text { - grupa wiekowa 25-64 lata }\end{array}$} \\
\hline & $\begin{array}{c}\text { część } \\
\text { niemiecka }\end{array}$ & $\begin{array}{c}\text { część } \\
\text { szwedzka }\end{array}$ & $\begin{array}{l}\text { część } \\
\text { polska }\end{array}$ & $\begin{array}{c}\text { część } \\
\text { niemiecka }\end{array}$ & $\begin{array}{c}\text { część } \\
\text { szwedzka }\end{array}$ & $\begin{array}{l}\text { część } \\
\text { polska }\end{array}$ & Euroregion \\
\hline 2001 & 0,55 & 0,22 & 0,23 & 63,55 & 52,7 & 66,5 & 60,92 \\
\hline 2004 & 0,49 & 0,23 & 0,28 & 61,60 & 53,5 & 65,3 & 60,13 \\
\hline 2007 & 0,48 & 0,25 & 0,27 & 64,00 & 45,3 & 64,7 & 58,00 \\
\hline 2010 & 0,48 & 0,26 & 0,26 & 65,05 & 44,5 & 65,0 & 58,18 \\
\hline 2014 & $\begin{array}{l}\text { brak } \\
\text { danych }\end{array}$ & $\begin{array}{l}\text { brak } \\
\text { danych }\end{array}$ & $\begin{array}{c}\text { brak } \\
\text { danych }\end{array}$ & 67,55 & 44,0 & 62,5 & 58,00 \\
\hline
\end{tabular}

Źródło: opracowanie własne na podstawie danych z Sekretariatu Euroregionu Pomerania i bazy Eurostat.

Jednocześnie duża liczba osób z minimum średnim wykształceniem występuje w niemieckiej i polskiej części euroregionu. W niemieckiej części Euroregionu Pomerania udział grupy wzrasta z poziomu 63,6\% w 2001 r. do 67,55\% w 2014 r., a w części polskiej liczba osób spada z poziomu 66,5 do 62,5\%.

W Euroregionie Pro Europa Viadrina zmniejsza się liczba studentów. Analiza wskaźnika liczby studentów w poszczególnych częściach Euroregionu pokazuje, że w całym analizowanym okresie procentowy udział polskich studentów był wyższy. 
Tabela 5.7. Wybrane dane o edukacji w Euroregionie Pro Europa Viadrina

\begin{tabular}{|c|c|c|c|c|c|}
\hline \multirow[t]{2}{*}{ Lata } & \multicolumn{2}{|c|}{$\begin{array}{c}\text { Udział studentów } \\
\text { w poszczególnych częściach } \\
\text { do całkowitej liczby studentów } \\
\text { euroregionu }=1\end{array}$} & \multicolumn{3}{|c|}{$\begin{array}{l}\text { Osoby z minimum średnim wykształceniem } \\
\qquad(\%) \text { - grupa wiekowa } 25-64 \text { lata }\end{array}$} \\
\hline & część niemiecka & część polska & część niemiecka & część polska & Euroregion \\
\hline 2001 & 0,46 & 0,54 & 64,8 & 69,45 & 67,125 \\
\hline 2004 & 0,40 & 0,60 & 62,1 & 67,65 & 64,875 \\
\hline 2007 & 0,40 & 0,60 & 63,3 & 68,40 & 65,850 \\
\hline 2010 & 0,41 & 0,59 & 63,4 & 67,60 & 65,500 \\
\hline 2014 & brak danych & brak danych & 66,2 & 64,95 & 65,580 \\
\hline
\end{tabular}

Źródło: opracowanie własne na podstawie danych z Sekretariatu Euroregionu Pro Europa Viadrina i bazy Eurostat.

Podobnie sytuacja wygląda w przypadku osób posiadających wykształcenie minimum średnie. Dysproporcje w wielkości wskaźnika nie są tak wysokie jak w przypadku udziału liczby studentów, ale również można zauważyć, że po polskiej stronie występuje większy procentowy udział osób posiadających średnie lub wyższe wykształcenie. Dopiero w 2014 r. proporcja ta ulega zmianie.

W Euroregionie Sprewa-Nysa-Bóbr wyraźnie widać, że w całym analizowanym okresie liczba studentów po stronie polskiej wynosiła około $70 \%$ całej liczby studentów w Euroregionie.

Tabela 5.8. Wybrane dane o edukacji w Euroregionie Sprewa-Nysa-Bóbr

\begin{tabular}{|c|c|c|c|c|c|}
\hline \multirow[t]{2}{*}{ Lata } & \multicolumn{2}{|c|}{$\begin{array}{c}\text { Udział studentów } \\
\text { w poszczególnych częściach } \\
\text { do całkowitej liczby studentów } \\
\text { euroregionu =1 }\end{array}$} & \multicolumn{3}{|c|}{$\begin{array}{l}\text { Osoby z minimum średnim wykształceniem } \\
(\%) \text { - grupa wiekowa 25-64 lata }\end{array}$} \\
\hline & część niemiecka & część polska & część niemiecka & część polska & Euroregion \\
\hline 2001 & 0,34 & 0,66 & 64,8 & 71,85 & 68,325 \\
\hline 2004 & 0,28 & 0,72 & 62,1 & 70,50 & 66,300 \\
\hline 2007 & 0,28 & 0,72 & 63,3 & 71,85 & 67,575 \\
\hline 2010 & 0,28 & 0,72 & 63,4 & 69,30 & 66,350 \\
\hline 2014 & brak danych & brak danych & 66,2 & 67,05 & 66,600 \\
\hline
\end{tabular}

Źródło: opracowanie własne na podstawie danych z Sekretariatu Euroregionu Sprewa-Nysa -Bóbr oraz Eurostat.

Jednocześnie odsetek studentów w Euroregionie obniżył się, co jest zgodne z ogólną tendencją demograficzną i spadkiem liczby ludności. Jednocześnie w Euroregionie Sprewa-Nysa-Bóbr jest wysoki procent ludności posiadającej minimum średnie wykształcenie. 
Liczba osób pomiędzy 25. a 64. rokiem życia w Euroregionie, która posiada wykształcenie średnie lub wyższe, wynosi w całym analizowanym okresie ponad 66\%. W 2014 r. w polskiej części Euroregionu liczba osób z wykształceniem średnim i wyższym wynosi $67,05 \%$, a w części niemieckiej $66,2 \%$.

W Euroregionie Neisse-Nisa-Nysa udział studentów z poszczególnych części euroregionu największy jest po stronie niemieckiej, gdzie studenci stanowią 48\% wszystkich studentów w roku 2001, natomiast w 2010 r. - 42\%. Procentowy udział studentów z polskiej części jest jedynie nieznacznie niższy i w 2012 r. stanowi $40 \%$ wszystkich studentów. Najmniejsza liczba studentów jest po stronie czeskiej, gdzie w całym badanym okresie stanowią oni średnio $17,5 \%$ całej grupy studentów Euroregionu.

Tabela 5.9. Wybrane dane o edukacji w Euroregionie Neisse-Nisa-Nysa

\begin{tabular}{|c|c|c|c|c|c|c|c|}
\hline \multirow{2}{*}{ Lata } & \multicolumn{3}{|c|}{$\begin{array}{c}\text { Wskaźnik ilości studentów } \\
\text { w poszczególnych częściach } \\
\text { do całkowitej liczby studentów } \\
\text { euroregionu }\end{array}$} & \multicolumn{3}{|c|}{\begin{tabular}{c}
\multicolumn{2}{|c|}{ Osoby z minimum średnim wykształce- } \\
niem (\%) - grupa wiekowa 25-64 lata
\end{tabular}} \\
\cline { 2 - 8 } & $\begin{array}{c}\text { część } \\
\text { niemiecka }\end{array}$ & $\begin{array}{c}\text { cześć } \\
\text { polska }\end{array}$ & $\begin{array}{c}\text { część } \\
\text { czeska }\end{array}$ & $\begin{array}{c}\text { część } \\
\text { niemiecka }\end{array}$ & $\begin{array}{c}\text { czesść } \\
\text { polska }\end{array}$ & $\begin{array}{c}\text { czesść } \\
\text { czeska }\end{array}$ & $\begin{array}{c}\text { Eurore- } \\
\text { gion }\end{array}$ \\
\hline 2001 & 0,48 & 0,35 & 0,18 & 64,3 & 69,1 & 77,8 & 70,40 \\
\hline 2004 & 0,42 & 0,41 & 0,17 & 63,0 & 68,4 & 80,3 & 70,57 \\
\hline 2007 & 0,43 & 0,4 & 0,17 & 63,5 & 69,3 & 79,6 & 70,80 \\
\hline 2010 & 0,42 & 0,4 & 0,18 & 63,7 & 67,8 & 78,5 & 70,00 \\
\hline 2014 & brak danych & brak danych & $\begin{array}{c}\text { brak } \\
\text { danych }\end{array}$ & 67,4 & 64,7 & 75,3 & 69,13 \\
\hline
\end{tabular}

Źródło: opracowanie własne na podstawie danych z Sekretariatu Euroregionu Sprewa-Nysa -Bóbr oraz Eurostat.

Ilość osób posiadająca średnie lub wyższe wykształcenie najwyższa jest po stronie czeskiej i stanowi ponad 75\% ludności w wieku 25-64. W niemieckiej części Euroregionu odsetek tej grupy w 2014 r. stanowił $67,4 \%$. W polskiej części zauważalny jest natomiast niewielki procentowy spadek liczby osób $\mathrm{z}$ analizowanej próby z poziomu 69,1\% w 2001 r. do poziomu 64,7\% w roku 2014.

\section{Warunki mieszkaniowe}

Poziom życia mieszkańców poszczególnych euroregionów uzależniony jest od warunków mieszkaniowych. Można zauważyć, że w każdym z euroregionów po stronie niemieckiej warunki mieszkaniowe są zdecydowanie lepsze. Przeciętna powierzchnia mieszkaniowa przypadająca na 1 osobę jest po stronie niemieckiej dwa razy większa w porównaniu z częścią polską (tabela 5.10). 
W Euroregionie Pomerania przeciętnie na mieszkanie w części niemieckiej przypadają 2 osoby, w części polskiej 3. Powierzchnia użytkowa na 1 osobę w części polskiej wynosi 22,6 $\mathrm{m}^{2}$, natomiast $\mathrm{w}$ części niemieckiej jest 1,7 razy większa i wynosi 39,2 m². W Euroregionie Pro Europa Viadrina w części polskiej na mieszkanie przypadają 3 osoby, a w części niemieckiej 2, powierzchnia użytkowa w części polskiej wynosi $22,7 \mathrm{~m}^{2}$, a w części niemieckiej $38,7 \mathrm{~m}^{2}$.

Tabela 5.10. Zasoby mieszkaniowe w euroregionach na pograniczu zachodnim (2010 r.)

\begin{tabular}{|c|c|c|c|c|}
\hline \multirow{2}{*}{ Euroregiony na pograniczu zachodnim } & \multirow{2}{*}{$\begin{array}{c}\text { Przeciętna liczba } \\
\text { osób na } \\
\text { mieszkanie }\end{array}$} & \multicolumn{2}{|c|}{$\begin{array}{c}\text { Przeciętna powierzchnia } \\
\text { użytkowa }\left(\mathrm{m}^{2}\right)\end{array}$} \\
\cline { 4 - 5 } & & mieszkania & na 1 osobę \\
\hline \multirow{2}{*}{ Pomerania } & część polska & 2,9 & 65,8 & 22,6 \\
\cline { 2 - 5 } & część niemiecka & 1,9 & 75,8 & 39,2 \\
\hline \multirow{2}{*}{ Pro Europa Viadrina } & część polska & 3,0 & 68,1 & 22,7 \\
\cline { 2 - 5 } & część niemiecka & 1,9 & 75,3 & 38,7 \\
\hline \multirow{3}{*}{ Sprewa-Nysa-Bóbr } & część polska & 3,0 & 69,9 & 23,1 \\
\cline { 2 - 5 } & część niemiecka & 1,9 & 72,9 & 39,1 \\
\hline \multirow{3}{*}{ Neisse-Nisa-Nysa } & część polska & 2,9 & 68,9 & 23,9 \\
\cline { 2 - 5 } & część czeska & 2,7 & 48,7 & 18,3 \\
\cline { 2 - 5 } & część niemiecka & 1,9 & 74,1 & 38,4 \\
\hline
\end{tabular}

Źródło: GUS, Euroregiony na granicach Polski, http://www.stat.gov.pl/cps/rde/xbcr/wroc/ ASSETS_43-88.pdf [dostęp 17.05.2015].

Podobne wartości wskaźników jak w euroregionach Pomerania i Pro Europa Viadrina odnotowano w Euroregionie Sprewa-Nysa-Bóbr i Neisse-Nisa-Nysa. W tym ostatnim można zauważyć, że najmniejsza powierzchnia użytkowa jest w części czeskiej Euroregionu i wynosi 18,3 osób $/ \mathrm{m}^{2}$. Warunki mieszkaniowe są zdecydowanie lepsze w niemieckich częściach euroregionów.

\section{Usługi medyczne i służba zdrowia}

Ważnym wskaźnikiem poziomu i jakości życia jest poziom służby zdrowia i świadczenia usług medycznych. Dla potrzeb niniejszej dysertacji analizie poddane zostaną: liczba lekarzy na 100 tys. mieszkańców oraz liczba łóżek w szpitalach na 100 tys. mieszkańców.

Zgodnie z danymi wyznaczonymi dla poszczególnych części euroregionów widać wyraźnie, że najwięcej lekarzy jest po stronie niemieckiej i po stronie szwedzkiej. W Euroregionie Pomerania liczba lekarzy wzrastała w całym badanym okresie. Najmniejsza liczba lekarzy jest po stronie polskiej, zaś największa po stronie szwedzkiej (po stronie szwedzkiej jest ich 1,5 razy więcej). 
Tabela 5.11. Liczba lekarzy na 100 tys. mieszkańców

\begin{tabular}{|c|c|c|c|c|c|c|c|c|}
\hline Euroregiony & Części & 2000 & 2002 & 2004 & 2006 & 2008 & 2010 & 2011 \\
\hline \multirow{4}{*}{$\begin{array}{c}\text { Euroregion } \\
\text { Pomerania }\end{array}$} & polska & 209,20 & 218,19 & 241,11 & 218,30 & 215,47 & 237,52 & 250,40 \\
\cline { 2 - 9 } & niemiecka & 281,40 & 289,67 & 303,95 & 315,46 & 324,39 & 340,10 & 348,96 \\
\cline { 2 - 9 } & szwedzka & 324,48 & 347,70 & 362,76 & 373,10 & 384,88 & 393,71 & 399,51 \\
\cline { 2 - 9 } & Euroregion & 279,14 & 292,44 & 309,91 & 309,59 & 315,04 & 331,54 & 341,58 \\
\hline \multirow{4}{*}{$\begin{array}{c}\text { Euroregion } \\
\text { Pro Europa } \\
\text { Viadrina }\end{array}$} & polska & 193,17 & 193,82 & 215,06 & 202,77 & 198,49 & 212,35 & 226,70 \\
\cline { 2 - 9 } & niemiecka & 259,07 & 267,92 & 282,06 & 293,54 & 303,98 & 316,82 & 323,07 \\
\hline \multirow{4}{*}{$\begin{array}{c}\text { Euroregion } \\
\text { Sprewa } \\
\text {-Nysa-Bóbr }\end{array}$} & Euroregion & 245,95 & 249,06 & 257,38 & 255,58 & 267,36 & 280,36 & 284,66 \\
\cline { 2 - 9 } & niemiecka & 259,07 & 267,92 & 282,06 & 293,54 & 303,98 & 316,82 & 323,07 \\
\hline \multirow{2}{*}{$\begin{array}{c}\text { Euroregion } \\
\text { Neisse-Nisa } \\
\text {-Nysa }\end{array}$} & niemiecka & 286,11 & 293,96 & 303,42 & 314,31 & 326,66 & 345,75 & 356,27 \\
\cline { 2 - 9 } & czeska & $\begin{array}{c}\text { brak } \\
\text { danych }\end{array}$ & $\begin{array}{c}\text { brak } \\
\text { danych }\end{array}$ & 308,76 & 311,95 & 314,32 & 315,99 & 320,06 \\
\cline { 2 - 9 } & Euroregion & 259,21 & 265,29 & 279,55 & 279,15 & 285,48 & 287,50 & 297,93 \\
\hline
\end{tabular}

Źródło: opracowanie własne na podstawie bazy danych Eurostat.

Tabela 5.12. Liczba łóżek w szpitalach na 100 tys. mieszkańców

\begin{tabular}{|c|c|c|c|c|c|c|}
\hline Euroregiony & Części & 2003 & 2005 & 2007 & 2009 & 2011 \\
\hline \multirow{4}{*}{ Pomerania } & polska & 1047,09 & 1040,88 & 1033,35 & 1124,40 & 1239,29 \\
\cline { 2 - 7 } & niemiecka & 783,88 & 785,66 & 776,33 & 811,01 & 828,35 \\
\cline { 2 - 7 } & szwedzka & 314,68 & 306,45 & 297,19 & 282,62 & 277,04 \\
\cline { 2 - 7 } & Euroregion & 715,22 & 711,00 & 702,29 & 739,34 & 781,56 \\
\hline \multirow{4}{*}{$\begin{array}{c}\text { Pro Europa } \\
\text { Viadrina }\end{array}$} & polska & 828,50 & 788,33 & 775,92 & 826,89 & 885,68 \\
\cline { 2 - 7 } & niemiecka & 825,65 & 818,73 & 812,27 & 818,95 & 823,34 \\
\cline { 2 - 7 } & Euroregion & 827,08 & 803,53 & 794,1 & 822,92 & 854,51 \\
\hline \multirow{3}{*}{$\begin{array}{c}\text { Sprewa } \\
\text {-Nysa-Bóbr }\end{array}$} & polska & 577,00 & 531,33 & 518,91 & 530,84 & 522,63 \\
\cline { 2 - 7 } & niemiecka & 825,65 & 818,73 & 812,27 & 818,95 & 823,34 \\
\cline { 2 - 7 } & Euroregion & 701,33 & 675,03 & 665,59 & 674,89 & 672,99 \\
\hline \multirow{4}{*}{$\begin{array}{c}\text { Neisse-Nisa } \\
-N y s a\end{array}$} & polska & 833,12 & 810,30 & 783,27 & 798,90 & 778,19 \\
\cline { 2 - 7 } & niemiecka & 881,15 & 853,88 & 837,85 & 848,34 & 851,89 \\
\cline { 2 - 7 } & czeska & $\begin{array}{c}\text { brak } \\
\text { danych }\end{array}$ & $\begin{array}{c}\text { brak } \\
\text { danych }\end{array}$ & 683,45 & 681,92 & 660,86 \\
\cline { 2 - 7 } & Euroregion & 857,14 & 832,09 & 768,19 & 776,39 & 763,65 \\
\hline
\end{tabular}

Źródło: opracowanie własne na postawie bazy danych Eurostat. 
W Euroregionach Pro Europa Viadrina, Sprewa-Nysa-Bóbr oraz Neisse-Nisa -Nysa sytuacja wygląda podobnie. Najmniejszy dostęp do opieki lekarskiej jest po stronie polskiej. Niepokojące jest to, że w części polskiej euroregionów Sprewa -Nysa-Bóbr i Neisse-Nisa-Nysa liczba lekarzy na 100 tys. mieszkańców spadała.

W Euroregionie Pomerania liczba łóżek na przestrzeni lat 2003-2011 wzrosła z poziomu 715 do 781 . Z kolei w Euroregionie Sprewa-Nysa-Bóbr spadła z poziomu 701 do 672, podobny trend zauważalny jest w Euroregionie Neisse-Nisa-Nysa, gdzie liczba łóżek na 100 tys. mieszkańców spadła z poziomu 857 do 763.

\subsubsection{Infrastruktura i przemysł}

Położenie geograficzne Euroregionu Pomerania powoduje, że jego obszar pełni ważną funkcję w ruchu tranzytowym i transporcie międzynarodowym. Infrastruktura komunikacyjna i położenie w rejonie Zatoki Szczecińskiej determinuje poziom rozwoju gospodarczego Euroregionu. Korzystnym uwarunkowaniem jego rozwoju są porty morskie i śródlądowe, które dzięki całej sieci połączeń pasażerskich i towarowych odgrywają główną rolę w transporcie. Do najważniejszych portów w Euroregionie należą: polskie (Szczecin, Police, Świnoujście) oraz niemieckie (Stralsund, Schwedt/Oder i Eberswalde). Na terenie Euroregionu znajduje się również port lotniczy Szczecin-Goleniów. Sieć dróg jest bardzo dobrze rozbudowana w szwedzkiej części Euroregionu, natomiast polska i niemiecka część wymagają podjęcia szeregu inwestycji w celu ulepszenia i rozbudowy infrastruktury drogowej. Jednocześnie zauważalna jest wzajemna współpraca pomiędzy poszczególnymi częściami Euroregionu w ramach wymiany handlowej i dokonywania inwestycji po różnych stronach granic. Głównymi gałęziami gospodarki w Euroregionie jest przemysł stoczniowy (Szczecin), przemysł spożywczy, leczniczy, papierowy i drzewny (Schwedt nad Odrą), chemiczny (Police), samochodowy i elektromaszynowy ${ }^{25}$. W strukturze gospodarki dominują małe i średnie przedsiębiorstwa (89,5\% przedsiębiorstw stanowią podmioty zatrudniające do 9 pracowników), które działają w następujących sektorach ${ }^{26}$ : handel i naprawa pojazdów mechanicznych (22\%), budownictwo (14,2\%), turystyka (10,6\%), usługi naukowe i techniczne świadczone przez osoby wolnych zawodów (8,6\%), opieka zdrowotna i społeczna (7,8\%), sektor produkcji (5\%).

Euroregion Pro Europa Viadrina znajduje się na szlaku komunikacyjnym Rotterdam-Berlin-Warszawa-Moskwa. Przez polską część Euroregionu przebiega droga krajowa S3 (trasa Północ Południe Europy) oraz A2 łącząca wschód z za-

25 Euroregion Pomerania, Krótka prezentacja, Polska, Deutschalnd, Sverige, http://www.pome rania.org.pl/file.php?id=88, s. 11 [dostęp 10.09.2013].

26 http://www.pomerania.net/download/KRD_Pomerania_2014-20_PL_2013-09-30_mit_ Teilkonzepten.pdf, s. 54-55 [dostęp 10.09.2013]. 
chodem Europy. Przez niemiecką część przebiega autostrada A12, którą można dostać się do Berlina lub Frankfurtu, oś wschód-zachód i północ-południe połączona została poprzez sieć dróg federalnych. Euroregion Pro Europa Viadrina położony jest na tle korytarza transportowego TEN-2. Na obszarze Euroregionu znajdują się cztery przejścia graniczne: w Hohenwutzen-Osinow i Kostrzyn-Kustrin-Kietz, Słubice-Frankfurt nad Odrą, Świecko-Frankfurt nad Odrą, Kunowice-Frankfurt nad Odrą. W Euroregionie występują również porty żeglugi śródlądowej (np. Gorzów, Furstenwalde) oraz planowane są kolejne inwestycje w ramach projektu Odra dla turystów współfinansowanego przez UE ${ }^{27}$. Głównymi centrami gospodarczymi są miasta: Frankfurt, Eisenhüttenstadt, Gorzów, Kostrzyn, Słubice. Gospodarka w Euroregionie Pro Europa Viadrina opiera się w znacznej mierze na małych i średnich przedsiębiorstwach. W części polskiej podstawą funkcjonowania gospodarki jest sektor przemysłowy i handlowo-usługowy. W niemieckiej części Euroregionu występuje duża liczba małych i średnich przedsiębiorstw działających w różnych branżach. Do dominujących gałęzi przemysłu należy zaliczyć: budownictwo, przemysł spożywczy, chemiczny, lotniczy, urządzeń kolejowych, papierniczy i drzewny ${ }^{28}$. W polskiej części Euroregionu Pro Europa Viadrina rośnie liczba zakładów w budownictwie (w 2010 r. było ich 1664 ), rozwijają się usługi, natomiast spadek zauważalny jest w przetwórstwie.

Euroregion Sprewa-Nysa-Bóbr jest częścią korytarza paneuropejskiego III8 z osią komunikacyjną Berlin-Cottbus-Wrocław. Przez Euroregion przebiega autostrada A2 z Berlina do Warszawy oraz Europejski Korytarz Transportowy (autostrada A18) oraz drogi o znaczeniu transgranicznym (B97, B112, B115, B156). Na obszarze Euroregionu Sprewa-Nysa-Bóbr funkcjonują przejścia graniczne w Gubin-Guben, Guben/Schlagsdorf-Gubinek, Forst-Olszyna i Forst-Zasieki oraz Łęknica-Bad Muskau i Przewóz-Podrosche. Transport kolejowy w Euroregionie jest ograniczony (w części niemieckiej ograniczona została oferta Kolei Niemieckich, z tego wynika mała liczba połączeń pomiędzy częścią polską a niemiecką). Na uwagę zasługuje fakt, że przez Euroregion przebiega trasa kolejowa łącząca Berlin i Warszawę. Na terenie Euroregionu są cztery lotniska po stronie niemieckiej: Cottbus-Nord (wojskowe), Neunhausen (aeroklub), Welzow i Drewitz (lotnictwo cywilne). W części polskiej lotnisko Zielona Góra Babimost International Airport oraz w Przylepie (okolice Zielonej Góry). Transport wodny po stronie niemieckiej ze względu na utrudnienia na rzece i niewielką jej głębokość nie istnieje, natomiast po stronie polskiej odbywa się głównie na Odrze. Porty na Odrze zlokalizowane

27 http://www.euroregion-viadrina.de/cms/upload/EHK_2014_-_2020_polnische_Printfas sung_-_Download.pdf, s. 32-33 [dostęp 10.09.2013].

28 http://www.euroregion-viadrina.de/cms/upload/Downloads/PDF/DE/EHK_07_pl.pdf, s. 11-12 [dostęp 10.09.2013]. 
są w Nowej Soli, Bytomiu Odrzańskim, w Uradzie oraz Krośnie Odrzańskim² ${ }^{29}$. W niemieckiej części Euroregionu głównymi działami gospodarki są: administracja publiczna, handel, naprawa pojazdów mechanicznych, przemysł przetwórczy, wydobywczy (kopalnie Janschwalde, Cottbus-Nord, Welzow-Sud). W polskiej części Euroregionu rozwijają się branże, takie jak: handel detaliczny, przemysł drzewny, produkcja mebli, przemysł włókienniczy i skórzany, usługi transportowe i finansowe.

W niemieckiej części Euroregionu Neisse-Nisa-Nysa układ dróg związany jest z programem rozwoju regionalnego Saksonii, który oparty został o ponadregionalne osie komunikacyjno-rozwojowe (np. Drezno-Berlin, Cottbus-Berlin, Drezno-Wrocław) oraz regionalne osie komunikacyjne (np. Lipsk-Hoyerswerda). Czeska część położona jest pomiędzy międzynarodowymi korytarzami autostrad D8 (Praga-Drezno) oraz D11 (Praga-Lubawka-Szczecin). Polski obszar Euroregionu obejmuje III Paneuropejski Korytarz Transportowy tworzony przez autostrady A4 i A12. Wschodnia część natomiast wpisuje się w autostradę Szczecin -Lubawka A3. W Euroregionie Neisse-Nisa-Nysa dominującą gałęzią przemysłu są usługi, rozwija się również przemysł maszynowy i budownictwo. Największa liczba zarejestrowanych podmiotów gospodarczych znajduje się po stronie czeskiej, a najmniejsza po stronie niemieckiej ${ }^{30}$.

\subsubsection{Rolnictwo i turystyka}

\section{Rolnictwo w euroregionach}

W Euroregionie Pomerania rolnictwo jest głównym źródłem dochodów na wsiach. W Euroregionie występują dobre warunki naturalne do uprawy roślin. W części niemieckiej Euroregionu na Pomorzu Północnym dominują równiny z glebami dobrej jakości, a na Pomorzu Przednim gleby piaszczysto-gliniaste. Średnie opady to około $600 \mathrm{~mm}$, a średnia temperatura $8^{\circ} \mathrm{C}$. W części polskiej w województwie zachodniopomorskim dominuje klimat umiarkowany oraz dobre jakościowo gleby. W części szwedzkiej dominują bardzo dobre gleby powapienne i równinny krajobraz. Wielkość średniego gospodarstwa rolnego po stronie niemieckiej wynosiła w 2010 r. 275 ha (występują zarówno małe gospodarstwa rodzinne, jak i duże przedsiębiorstwa agrarne), po stronie polskiej dominują małe gospodarstwa rolne o powierzchni około 20 ha, w części szwedzkiej dominują średnie gospodarstwa o powierzchni 65 ha. W części niemieckiej obszary wykorzystywane rolniczo stanowią niespełna $60 \%$ powierzchni (78\% grunty orne, $21 \%$ użytki zielone, $0,4 \%$ owoce i warzywa, $5 \%$ ziemniaki i buraki cukrowe), nieko-

29 http://euroregion-snb.pl/media/dokumenty/Plan_rozwoju_i_dzia_ania.pdf, s. 50-55 [dostęp 10.10.2014].

30 http://euroregion-nysa.pl [dostęp 10.10.2014]. 
rzystnym trendem jest spadek pogłowia zwierząt hodowlanych (średnio 40 szt. na 100 ha), trzody chlewnej i drobiu. W tej części Euroregionu tereny zalesione stanowią około $45 \%$ powierzchni całkowitej w rejonie Barnim oraz 15\% na Wyspie Rugia. W części polskiej $11000 \mathrm{~km}^{2}$ stanowią obszary użytkowane rolniczo (880 000 ha gruntów rolnych, 230000 ha użytków zielonych i 3900 ha upraw ogrodowych). Wysoki udział osób zatrudnionych w rolnictwie (1/4) wyraźnie wskazuje na duże znaczenie rolnictwa dla obszarów wiejskich. Głównymi uprawami są zboża (75\%) i rośliny przemysłowe (8\%). W części szwedzkiej Euroregionu występuje wysoki poziom zmechanizowania rolnictwa, co powoduje, że w tej części jedynie 3\% osób zatrudnionych jest $w$ rolnictwie. Dominującymi działami w rolnictwie w regionie Skanii jest przede wszystkim uprawa ziemniaków, buraków cukrowych, owoców i warzyw skierowana głównie do wewnętrznego dobrze rozwiniętego sektora spożywczego. W Euroregionie Pomerania rozwija się również rybołówstwo morskie i przybrzeżne oraz wydobycie surowców naturalnych dla przemysłu budowlanego

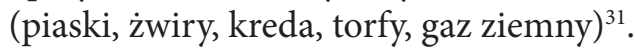

W niemieckiej części Euroregionu Pro Europa Viadrina połowę powierzchni zajmują tereny wykorzystywane rolniczo. Dobre gleby powodują, że coraz większe znaczenie w Euroregionie zajmują uprawy ekologiczne (około 7\% w całości rolnictwa w roku 2012). W polskiej części Euroregionu obszar rolniczy stanowi 33\% powierzchni przy czym użytki rolne to około 200000 ha. W tej części Euroregionu widać wyraźnie, że gospodarstwa typowo rolnicze przekształcają się w gospodarstwa agroturystyczne $z$ bogatą ofertą turystyczną. Jednocześnie zmniejsza się liczba małych zakładów rolnych, a zwiększa średni areał upraw ${ }^{32}$.

Znaczenie rolnictwa dla rozwoju Euroregionu Sprewa-Nysa-Bóbr jest niewielkie, związane jest to z niską jakością gleb, co jest rezultatem funkcjonowania kopalni węgla brunatnego. Powierzchnia rolna w Euroregionie stanowi niespełna 370000 ha. W polskiej części rolnictwo nie odgrywa dużej roli, co wynika z tradycji przemysłowej w Euroregionie i restrukturyzacji rolnictwa, która doprowadziła do lepszego wykorzystania lasów i obszarów rolnych w turystyce. W Euroregionie Sprewa-Nysa-Bóbr rozwija się hodowla ryb. Rolnictwo w niemieckiej części Euroregionu odgrywa dużą rolę w rekultywacji terenów po starych kopalniach węgla brunatnego. Coraz większego znaczenia w Euroregionie nabierają surowce odnawialne, w szczególności biomasa i drewno, będące alternatywą dla energii uzyskiwanej z węgla brunatnego ${ }^{33}$.

31 Transgraniczna Koncepcja rozwoju i działania Euroregionu Pomerania na lata 2000-2006, Berlin 1999, s. 62-64.

32 J. Pułkownik, Euroregion Pro Europa Viadrina jako przykład współpracy transgranicznej, „Zeszyty Studiów Doktoranckich/Uniwersytet Ekonomiczny w Poznaniu", nr 43/2005, s. 37-42.

33 Euroregion Sprewa-Nysa-Bóbr, Plan działania i rozwoju Euroregionu Sprewa-Nysa-Bóbr na lata 2014-2020, Gubin 2013, s. 100-103. 
W Euroregionie Neisse-Nisa-Nysa w strukturze gruntów rolnych 47\% stanowią użytki rolne, a lasy 41\% (2012 r.). Część zurbanizowana i zabudowana w Euroregionie stanowi tylko 6\% powierzchni. W porównaniu z początkiem funkcjonowania Euroregionu zmieniła się powierzchnia poszczególnych upraw. W części niemieckiej o 25\% zwiększyła się powierzchnia zasiewów zbóż, natomiast o prawie $25 \%$ zmniejszyła się powierzchnia uprawy ziemniaka i o $50 \%$ pozostałych warzyw i buraka cukrowego. W części czeskiej zwiększyła się uprawa buraka cukrowego. W polskiej części Euroregionu nastąpił wzrost powierzchni upraw strączkowych i rzepaku przy jednoczesnym zmniejszeniu uprawy innych warzyw, w tym ziemniaków. W porównaniu z latami 90 . XX w. w gospodarstwach rolnych zmniejszyło się wyraźnie pogłowie zwierząt gospodarczych.

\section{Turystyka w euroregionach}

Ważną rolę w Euroregionie Pomerania odgrywa turystyka. Związane jest to z położeniem geograficznym, dostępem do morza oraz dużą ilością obszarów zielonych. Stosunkowo niskie zanieczyszczenie powietrza, piękno krajobrazu oraz wspólne przenikanie się historii i tradycji sprawia, że dużą rolę w Euroregionie odgrywają obiekty historyczne i kulturalne (liczne pałace, zamki). Rozbudowana oferta turystyczna i hotelowa powoduje, że w Euroregionie obroty przemysłu turystycznego w ostatnim okresie wyraźnie wzrastają ${ }^{34}$.

Turystyka w Euroregionie Pro Europa Viadrina jest niezwykle istotnym uwarunkowaniem wzrostu gospodarczego. U podstaw rozwoju turystyki leży wykorzystanie naturalnych zasobów przyrody, tak aby „Przeżywać naturę na całym obszarze". Wśród zrealizowanych projektów turystyki transgranicznej należy wyróżnić między innymi Odra dla turystów, Szlak św. Jakuba, Odrzańsko-Nyski szlak rowerowy, Szlaki Przyrodniczo-Kulturowe po Ziemi Lubuskiej ${ }^{35}$.

W Euroregionie Sprewa-Nysa-Bóbr rozwój turystyki związany jest z różnorodnością krajobrazu, dużą liczbą jezior (ok. 150) i niską gęstością zaludnienia. Umożliwiło to rozwój sportów wodnych, jazdy konnej, ścieżek rowerowych i do wędrówek pieszych. Szczególnie istotnym obszarem turystycznym i rekreacyjnym jest Rezerwat Biosferyczny Szprewald, tereny kopalni odkrywkowej oraz sieć dróg wodnych (Lubuska Droga Wodna) ${ }^{36}$.

Rozwój turystyki ma kluczowe znaczenie dla rozwoju gospodarczego w Euroregionie Neisse-Nisa-Nysa. Wysoki poziom usług turystycznych wynika z jakości i walorów krajobrazu naturalnego i zasobów przyrody. Największymi atrakcjami są Karkonoski Park Narodowy, pasmo Gór Izerskich, formy i miasta skalne, zbiorniki

34 Euroregion Pomerania, Krótka prezentacja, s. 12.

35 Koncepcja Rozwoju i Działania Euroregionu Pro Europa Viadrina, Gorzów Wielkopolski-Frankfurt (Oder) 2013, s. 28-30.

36 http://euroregionsnb.pl/media/dokumenty/Ogolne/plan_rozwoju_i_dzialania_euroregio nu_sprewa_nysa_bobr.pdf, s. 103-107 [dostęp 12.05.2015]. 
wodne, lasy i jaskinie. W Euroregionie znajdują się również budynki o charakterze historyczno-kulturalnym, w tym zamki, pałace, kościoły i budynki sakralne.

Analizując dane związane z przyjazdami turystów, można zauważyć, że najwięcej turystów odwiedza Euroregion Pomerania (od roku 2000 do roku 2013 liczba turystów wzrosła 1,6 razy).

Najwięcej turystów odwiedza niemiecką część Euroregionu, najmniej natomiast odwiedza część polską. Sytuacja wygląda podobnie w przypadku pozostałych euroregionów na zachodniej granicy Polski. Niemiecką część Euroregionu Pomerania w 2013 r. odwiedziło 6,5 razy więcej turystów w porównaniu z częścią polską. W Euroregionie Pro Europa Viadrina w części niemieckiej w 2013 r. było 1,8 razy więcej turystów niż w części polskiej, w Euroregionie Sprewa-Nysa -Bóbr - 2 razy, natomiast w Euroregionie Neisse-Nisa-Nysa - 3,6 razy więcej.

Tabela 5.13. Liczba turystów odwiedzających euroregiony

\begin{tabular}{|c|c|c|c|c|c|c|}
\hline Euroregiony & Części & 2000 & 2004 & 2008 & 2012 & 2013 \\
\hline \multirow{4}{*}{$\begin{array}{c}\text { Euroregion } \\
\text { Pomerania }\end{array}$} & polska & 1179103 & 1073742 & 1362384 & 1536066 & 1588274 \\
\cline { 2 - 7 } & niemiecka & 7653433 & 8528588 & 9440830 & 10196576 & 10308475 \\
\cline { 2 - 7 } & szwedzka & 1957320 & 2107231 & 2106038 & 2169464 & 2220630 \\
\hline \multirow{2}{*}{$\begin{array}{c}\text { Euroregion } \\
\text { Pro Europa } \\
\text { Viadrina }\end{array}$} & puroregion & 8832536 & 9602330 & 10803214 & 11732642 & 14117379 \\
\cline { 2 - 7 } & polska & 1536956 & 1447772 & 1869678 & 2001761 & 2031011 \\
\hline \multirow{2}{*}{$\begin{array}{c}\text { Euroregion } \\
\text { Sprewa }\end{array}$} & puroregion & 4453856 & 4523988 & 5186837 & 5697064 & 5763874 \\
\cline { 2 - 7 }- niemiecka & 2916900 & 3076216 & 3317159 & 3695303 & 3732863 \\
\cline { 2 - 7 } & Euroregion & 4169366 & 4397341 & 5070605 & 5507869 & 5529645 \\
\hline \multirow{2}{*}{$\begin{array}{c}\text { Euroregion } \\
\text { Neisse }\end{array}$} & polska & 1224542 & 1246510 & 1564450 & 1702302 & 1729373 \\
\cline { 2 - 7 }- nisa-Nysa & czeska & 1570182 & 1445383 & 1417847 & 1637399 & 1643578 \\
\cline { 2 - 7 } & Euroregion & 7566540 & 7810634 & 8305349 & 9466698 & 9522622 \\
\hline
\end{tabular}

Źródło: opracowanie własne na podstawie bazy danych Sekretariatów euroregionów.

Biorąc pod uwagę rozwój turystyki w latach 2000-2013, na przestrzeni ponad dekady można zauważyć, że wzrost liczby turystów w euroregionach w porównaniu z okresem wyjściowym wyniósł ponad $20 \%$. 


\subsection{Wybrane inicjatywy euroregionów na rzecz rozwoju przedsiębiorczości i klastrów na zachodniej granicy Polski}

\section{Przedsiębiorczość w euroregionach}

Przedsiębiorczość jest jednym z podstawowych warunków rozwoju euroregionów, dlatego konieczne jest wsparcie i stworzenie jak najbardziej przyjaznych warunków dla prowadzących działalność gospodarczą. Niżej zaprezentowano kilka wybranych przedsięwzięć euroregionalnych na rzecz rozwoju przedsiębiorczości na obszarze transgranicznym Polski i Niemiec.

W działalność Euroregionu Pomerania na trwałe wpisało się Polsko-Niemieckie Forum Przedsiębiorczości, na którym poruszane są tematy związane ze wsparciem dla małych i średnich przedsiębiorstw, rozwojem innowacyjności i przedsiębiorczości, funkcjonowaniem inkubatorów przedsiębiorczości czy też transgraniczną współpracą gospodarczą. Wśród szkoleń należy wyróżnić choćby to związane z Dostępem do finansowania dla innowacyjnych mikro, matych $i$ średnich przedsiębiorstw w Regionie Morza Bałtyckiego, którego celem jest stymulacja w kierunku międzynarodowej kooperacji oraz dostęp do finansowania dla innowacyjnych $\mathrm{MSS}^{37}$. Ważną problematyką poruszaną na seminariach jest Nauczanie dwujęzyczne jako istotny czynnik rozwoju gospodarczego Euroregionu Pomerania. Dla przedstawicieli poszczególnych branż organizowane są szkolenia np. Polsko-niemiecka wymiana doświadczeń dla przedstawicieli branży budowlanej „Kamień naturalny - dar epoki lodowcowej" Szczecin-Meklemburgia-Pomorze Przednie czy też Polsko-niemiecka wymiana doświadczeń dla przedstawicieli branży odnawialnych źródet energii. Dla polskich przedsiębiorców organizowane są szkolenia i seminaria obejmujące problematykę prawno-organizacyjną prowadzenia działalności gospodarczej na terenie Niemiec. Przykładem może tu być seminarium Wybrane aspekty transgranicznej działalności gospodarczej na terenie Niemiec. W ramach współpracy euroregionalnej odbywają się również targi gospodarcze INKONTAKT oraz spotkania przedstawicieli branży budowlanej, innowacyjnych proekologicznych przedsiębiorstw ${ }^{38}$.

Kolejną ciekawą inicjatywą na rzecz rozwoju przedsiębiorczości jest stworzenie Centrum Usługowo-Doradczego Euroregionu Pomerania. Głównym celem powołanej instytucji jest wsparcie przedsiębiorców poprzez organizowanie konferen-

37 M. Czerniecka, Dostęp do finansowania dla innowacyjnych mikro, małych i średnich przedsiębiorstw w Regionie Morza Bałtyckiego. Forum Euroregion Pomerania Przedsiębiorczością stoi - 60, Polsko-Niemieckie Forum Przedsiębiorców, Szczecin 2011, s. 3.

38 Stowarzyszenie Gmin Polskich Euroregionu Pomerania, zakładka Aktualności, http://www. pomerania.org.pl/site/aktualnosci/172 [dostęp 17.12.2015]. 
cji branżowych, powstanie bazy danych gospodarczych, podnoszenie kwalifikacji przedsiębiorców, pomoc dla MŚP we wchodzeniu na nowe rynki zbytu (tłumaczenie umów, coaching, organizacja targów) ${ }^{39}$.

W Euroregionie Pomerania powstało centrum wspierania innowacji w Szczecinie - Szczeciński Park Naukowo-Technologiczny „Pomerania”, którego zadaniem jest wspieranie rozwoju przedsięwzięć innowacyjnych. Ciekawym przedsięwzięciem realizowanym w SPNT jest seminarium Wspieranie przedsiębiorczości - Erasmus dla młodych przedsiębiorców. Projekt ma na celu ułatwienie osobom zainteresowanym otwarciem działalności gospodarczej odbycia zagranicznego stażu w przedsiębiorstwach funkcjonujących i odnoszących sukcesy na rynku niemieckim $^{40}$.

W Euroregionie Pro Europa Viadrina pobudzanie lokalnej przedsiębiorczości jest jednym z podstawowych motywów funkcjonowania. W Euroregionie działa Główny Punkt Informacyjny Funduszy Strukturalnych w Zielonej Górze. W ramach tej inicjatywy odbywają się spotkania informacyjne dotyczące uzyskiwania dofinansowania z UE, przykładem mogą być tu szkolenia dotyczące Zwrotnego wsparcia dla lubuskich przedsiębiorców.

W Euroregionie Pro Europa Viadrina na rzecz rozwoju małych i średnich przedsiębiorstw utworzony został Lubuski Fundusz Pożyczkowy oraz Lubuski Fundusz Poręczeń Kredytowych. Jednocześnie uruchomiona została inicjatywa ukierunkowana na pomoc w zakresie finansowania działalności gospodarczej - Europejskie Centrum Doradztwa Finansowego ${ }^{41}$. Ciekawą inicjatywą Euroregionu Pro Europa Viadrina jest pomoc w wyszukiwaniu partnerów zagranicznych oraz ułatwienie kooperacji z przedsiębiorstwami po drugiej stronie granicy.

Ważną rolę w stymulowaniu przedsiębiorczości w Euroregionie Sprewa-Nysa -Bóbr odgrywają Targi Euroregionu oraz utworzony dla przedsiębiorców Bank Informacji Gospodarczej. W Euroregionie funkcjonuje prężnie działające Biuro Koordynacji Gospodarczej Euroregionu Sprewa-Nysa-Bóbr. Biuro jest wspólnym projektem realizowanym przez Organizację Pracodawców Ziemi Lubuskiej oraz Izbę Przemysłowo-Handlową z Cottbus. Priorytetem działania Biura jest intensyfikacja powiązań gospodarczych w Euroregionie, a także ułatwianie współpracy pomiędzy przedsiębiorstwami po obu stronach granicy oraz podnoszenie konku-

39 Stowarzyszenie Gmin i Powiatów Pomorza Przedniego, Centrum Usługowo Doradcze Euroregionu Pomerania, http://www.ko-pomerania.pl/index.php?option=com_content\&task =blogsection\&id=6\&ltemid=119 [dostęp 17.12.2015].

40 Urząd Miasta Szczecin, Informacja o bieżących sprawach/aktualności współpracy Międzynarodowej Miasta Szczecin, http://www.szczecin.pl/umszczecinSwiat/chapter_59233.asp?soid =03ADDC51251D42AB8699F53EAAFCB6CB [dostęp 10.11.2015].

41 Euroregion Pro Europa Viadrina, Wsparcie lubuskich przedsiębiorców - bezpłatne spotkanie informacyjne, http://www.euroregion-viadrina.pl/content/wsparcie-lubuskich-przedsi\%C4 \%99biorc\%C3\%B3w-\%E2\%80\%93-bezp\%C5\%82atne-spotkanie-informacyjne-\%E2\%80\%93-30042015-r [dostęp 17.10.2015]. 
rencyjności i wsparcie innowacyjnych małych i średnich przedsiębiorstw. Biuro służy również wsparciem dla przedsiębiorstw chcących wejść na rynki międzynarodowe (konsultacje z zakresu regulacji prawno-podatkowych, gospodarczych oraz językowych ${ }^{42}$. Ponadto w Euroregionie organizowanych jest szereg seminariów i konferencji dla przedsiębiorców. Spotkania dotyczą m.in. transgranicznego świadczenia usług, kooperacji polsko-niemieckiej w sektorze spożywczym, budowlanym, branży IT, zakładania i prowadzenia działalności gospodarczej w Niemczech czy też niemieckiego prawa podatkowego. Na obszarze euroregionu działa Organizacja Pracodawców Ziemi Lubuskiej, która zrzesza firmy z całego województwa lubuskiego. Zadaniem organizacji jest zapewnianie pełnego wsparcia dla przedsiębiorców oraz reprezentowanie ich interesów na forach krajowych i zagranicznych.

W Euroregionie Neisse-Nisa-Nysa funkcjonuje Bolesławieckie Towarzystwo Gospodarcze, które organizuje konferencje pt. Wspólpraca gospodarcza w Euroregionie Nysa. Celem konferencji jest zachęcenie przedsiębiorstw do nawiązania współpracy transgranicznej (przedstawienie liderów współpracy transgranicznej i wdrażania nowych innowacji). W ramach organizowanych eureoregionalnych przedsięwzięć należy wyróżnić odbywające się seminaria i szkolenia, których tematem są np. Innowacyjne metody wykorzystywania zasobów mineralnych dla rozwoju gospodarczego w Euroregionie Neisse-Nisa-Nysa $a^{43}$. Celem Euroregionu jest rozwój przedsiębiorczości poprzez kreowanie współpracy pomiędzy sferą biznesu a ośrodkami naukowo-badawczymi oraz pomoc w stworzeniu efektywnego regionalnego systemu innowacji. Jednocześnie władze regionalne podejmują działania pozwalające przedsiębiorcom na pokonywanie barier związanych z nieznajomością języków obcych, problemami w komunikacji, rozwiązywaniem kwestii formalno-prawnych oraz kształtowaniem powiązań pomiędzy podmiotami ${ }^{44}$.

\section{Wybrane inicjatywy klastrowe $w$ euroregionach na zachodniej granicy Polski}

Polityka rozwoju gospodarczego w euroregionach na zachodniej granicy Polski uwzględnia wsparcie finansowe dla klastrów. Interesującym przykładem jest tu Euroregion Pomerania, którego polska część obejmuje zasadniczy obszar województwa zachodniopomorskiego realizującego Regionalny program wspierania klastra na lata 2009-2015. Program uwzględnia wsparcie dla trzech rodzajów kla-

42 Organizacja Pracodawców Ziemi Lubuskiej, WIKOB Biuro Koordynacji Gospodarczej Euroregionu Sprewa-Nysa-Bóbr, http://www.opzl.pl/dzialalnosc/projekty/17,wikob_biuro_koor dynacji_gospodarczej_euroregionu_sprewa-nysa-bobr [dostęp 17.08.2015].

43 Bolesławieckie Towarzystwo Gospodarcze, http://www.btg.boleslawiec.pl/index.php?cat =6\&id=77 [dostęp 19.08.2015].

44 Strategia Rozwoju Euroregionu Nysa 2014-2020, http://www.jawor.pl/pliki/8/strategia-roz woju-euroregionu-nysa-2014-2020-pl.pdf, s. 36 [dostęp 15.05.2014]. 
strów: kluczowych, subregionalnych i sieci technologicznych. Podmioty tworzące tzw. klastry kluczowe dla rozwoju regionów uzyskują dodatkowe punkty w ramach Regionalnego programu operacyjnego i regionalnego komponentu Programu Operacyjnego Kapitał Ludzki. W polskiej części Euroregionu Pomerania istnieje dziewięć klastrów, w tym jeden o zasięgu międzynarodowym (Transgraniczny szlak wodny Berlin-Szczecin-Bałtyk). Dominującymi branżami w Euroregionie Pomerania, w których działają klastry, są: przemysł metalowy, chemiczny, morski, turystyka, medycyna, informatyka, technologie dotyczące środowiska naturalnego. Członkami klastrów w Euroregionie są przedsiębiorstwa, jednostki naukowe, instytucje otoczenia biznesu. Dominującymi podmiotami gospodarczymi są mikroprzedsiębiorstwa, które dominują w liczbie członków klastrów. Współpraca w gronach odbywa się w ścisłej kooperacji z instytucjami otoczenia biznesu.

Wyróżniającym się klastrem w Euroregionie Pomerania jest Stowarzyszenie Transgraniczny Klaster Turystyczny szlak wodny Berlin-Szczecin-Bałtyk. Powstał on na bazie funkcjonującej w Euroregionie Grupy Partnerskiej, a jego podstawowym celem było ukazanie szlaku jako wiodącej oferty turystycznej euroregionu ${ }^{45}$. Klaster jest organizacją obywateli zorganizowanych w organizacjach pozarządowych. Działania mające na celu realizację potrzeb społeczności lokalnych skupiają się wokół: wspierania rozwoju lokalnej społeczności, podniesienia poziomu i jakości życia, działań na rzecz zachowania i rozwoju lokalnych wartości kultury i tradycji ${ }^{46}$.

W Euroregionie Sprewa-Nysa-Bóbr działają cztery klastry, w których dominującymi branżami są przemysł metalowy, telekomunikacja i logistyka. Podobnie jak w Euroregionie Pomerania w strukturze klastra dominują przedsiębiorstwa małe. Wyróżniającą się siecią współpracy jest Lubuski Klaster Metalowy, w którego strukturze dominują przedsiębiorstwa średnie - jest ich dwanaście, małych - cztery, natomiast mikroprzedsiębiorstw - dwa.

W Euroregionach Pro Europa Viadrina i Neisse-Nisa-Nysa nie nawiązano współpracy klastrowej, choć są plany jej powołania. Szczególnie zaskakujący jest fakt, że nie zdecydowano się na rozwój współpracy w Euroregionie Neisse-Nisa -Nysa, choć w samym województwie dolnośląskim funkcjonuje 15 klastrów. Wydaje się, że zaleceniem dla władz wyżej wymienionych euroregionów jest konieczność stworzenia odpowiednich warunków dla rozwoju sieciowej współpracy przedsiębiorstw. Związane jest to $\mathrm{z}$ koniecznością endogenicznego pobudzania regionów transgranicznych oraz wpisuje się we współczesny trend teoretyczny określający składowe zrównoważonego rozwoju regionów.

45 Z. Zbroja, Transgraniczny Klaster Turystyczny-szlak wodny Berlin-Szczecin-Bałtyk, http://www. zagle.com.pl/srodladzie/locja/transgraniczny-klaster-turystyczny-szlak-wodny-ber,33_6731. html [dostęp 10.05.2015].

46 Transgraniczny Klaster szlak wodny Berlin-Szczecin-Bałtyk. Opis dobrej praktyki, http://berlinszczecin-baltyk.pl/ [dostęp 16.05.2015]. 


\subsection{Uwagi końcowe}

Trwały i zrównoważony rozwój odbywa się w ściśle określonych warunkach społecznych, gospodarczych, politycznych. Euroregiony na zachodnim pograniczu Polski należą do obszarów specyficznych, przez długi czas przebiegała przez nie granica oddzielająca państwa Unii Europejskiej od państw Europy Środkowo-Wschodniej. Znamienne jest, że części euroregionów położone po niemieckiej stronie charakteryzują się wyższym poziomem rozwoju społeczno-gospodarczego w porównaniu z częściami polskimi czy czeskimi. Wskaźniki ekonomiczne pozwalają jednak dostrzec pewien trend rozwojowy zwiastujący poprawę poziomu i jakości życia w euroregionach. Diagnoza sytuacji społeczno-ekonomicznej pokazuje, że w poszczególnych krajowych częściach euroregionów występuje duży stopień zróżnicowania rozwoju. Niewątpliwie w euroregionach podjęto szereg działań, które doprowadziły do polepszenia sytuacji gospodarczej i poprawy ochrony środowiska naturalnego. Mimo to konieczna jest dalsza realizacja wyznaczonych przez euroregiony celów i współdziałanie na rzecz zrównoważonego rozwoju obszarów peryferyjnych. 


\section{Rozdział 6}

\section{Potencjał i cele ekorozwoju w euroregionach na zachodnim pograniczu Polski}

\subsection{Uwagi wstępne}

Euroregiony, dążąc do realizacji idei zrównoważonego rozwoju, są niejako zobligowane do wyznaczania sobie celów uwzględniających specyfikę obszarów transgranicznych oraz warunków i możliwości ich realizacji. W rozdziale 6 przedstawiono cele euroregionów w zakresie rozwoju ekonomicznego, społecznego i ochrony środowiska naturalnego. Dokonano próby oceny mocnych, słabych stron, szans i zagrożeń sformalizowanej współpracy transgranicznej zachodniego pogranicza Polski. Przeprowadzono ocenę spójności w euroregionach, wskazano pozytywne doświadczenia, problemy oraz zadania na przyszłość.

\subsection{Cele euroregionów}

Głównym celem euroregionów jest osiągnięcie trwałego i zrównoważonego rozwoju poprzez optymalne wykorzystanie wewnętrznego potencjału rozwojowego i racjonalne zagospodarowanie środków pomocowych z Unii Europejskiej. Rozwój euroregionalny jest efektem jednoczesnego przenikania się szeregu czynników, do których zalicza się: kapitał ludzki, rzeczowy i finansowy, poziom innowacyjności, strukturę gospodarczą, poziom rozwoju infrastruktury technicznej, jakość i sprawność zarządzania szeroko rozumianymi zasobami regionów, efektywność administracji i władz regionalnych ${ }^{1}$.

1 P.Żuber, Rozwój regionalny w Polsce. Raport 2009, Ministerstwo Rozwoju Regionalnego, Warszawa 2009, s. 7. 
Działania władz euroregionalnych ukierunkowane są na zwiększanie poziomu konkurencyjności i optymalne wykorzystanie walorów gospodarczych, turystycznych i społecznych ${ }^{2}$. Poziom konkurencyjności euroregionów z udziałem Polski jest różny, a ich potencjał rozwojowy jest zdeterminowany przez szereg rozmaitych czynników ${ }^{3}$. Zrównoważony i trwały rozwój euroregionów wpisany jest w ich wewnętrzne strategie, koncepcje działania, dokumenty i programy pilotażowe. Działania podejmowane przez władze euroregionalne mają na celu wypracowanie i implementację wspólnych rozwiązań w obszarze polityki, gospodarki, kultury czy ochrony środowiska. Władze euroregionalne podejmują wspólne i kompleksowe działania mające na celu niwelowanie słabych stron euroregionów, zapobieganie pojawiającym się zagrożeniom oraz akcentowanie i podkreślanie mocnych stron i szans rozwojowych.

W Euroregionie Pomerania w okresie programowania na lata 2007-2013 wdrażana była Transgraniczna koncepcja działań i rozwoju Euroregionu Pomerania na lata 2007-2013, w myśl której „Wspólne działania są ukierunkowane na wypracowanie i implementację zintegrowanych rozwiązań w obszarach działań, takich jak polityka, gospodarka i kultura. Rozwiązania mają służyć zrównoważonemu rozwojowi regionu, szczególnie w celu zmniejszenia słabych stron i uporania się z nimi przez ukierunkowane strukturalne wyposażenie regionu, które powinno nastąpić w sposób kompleksowy"4. Wdrażanie koncepcji zrównoważonego i trwałego rozwoju w Euroregionie oparte zostało o priorytety strategiczne określone w programach z Lizbony i Göteborga oraz założenia unijnej polityki regionalnej na lata 2014-2020. Zrównoważony i trwały rozwój ma być osiągnięty przez: wsparcie konkurencyjności, budowę gospodarki opartej na wiedzy, wykorzystanie know-how, wsparcie dla lokalnej przedsiębiorczości, rozwój systemu sieci edukacyjnej dla ludności ${ }^{5}$.

Jednym z priorytetowych celów współpracy w Euroregionie Pro Europa Viadrina jest ochrona zasobów przyrody i wprowadzenie europejskich norm ekologicznych ${ }^{6}$. Koncepcja rozwoju i działania euroregionu podkreśla, że głównym zadaniem funkcjonowania Euroregionu jest rozwój społeczny, gospodarczy oraz

2 E. Wysocka, Istota i czynniki konkurencyjności w regionie, „Wójt i Jego Gmina”, nr 5/2006, S. 11-12.

3 R. Kosmalski, Konwergencja i nierówności regionalne w Polsce w świetle metody DEA (rozprawa doktorska), Uniwersytet Ekonomiczny w Poznaniu, Poznań 2011, s. 97; M. Stec, Znaczenie funduszy pomocowych Unii Europejskiej dla spójności społeczno-gospodarczej polskich regionów, Rzeszów 2011, s. 177-179.

4 Transgraniczna koncepcja działań i rozwoju Euroregionu Pomerania na lata 2007-2013. Wersja końcowa, Szczecin 2006, s. 6.

5 Mitteilung der Kommission, Gemeinsame Maßnahmen für Wachstum und Beschäftigung:Das Lissabonner Programm der Gemeinschaft, Brüssel 2005, s. 2.

6 K. Mączkowski, Przez Viadrinę do Europy ',"E-czytelnia”, nr 3(150)/2004, s. 12. 
transgraniczna współpraca na rzecz zrównoważonego rozwoju przestrzennego i ochrony środowiska naturalnego ${ }^{7}$.

W Euroregionie Sprewa-Nysa-Bóbr za nadrzędny cel zgodnie z umową, na mocy której Euroregion powstał, uznano „wszechstronną działalność na rzecz obszarów przygranicznych Rzeczypospolitej Polskiej i Republiki Federalnej Niemiec, ich sanacji ekologicznej, rozkwitu gospodarczego i kulturalnego oraz stałej poprawy warunków życia ich mieszkańców, w tym zniwelowanie istniejących różnic w sytuacji ekonomicznej"8. Główny kierunek rozwoju Euroregionu został zawarty w programie pilotażowym Ekorozwój w Euroregionie Sprewa-Nysa-Bóbr. Podkreślono, że spójność w wymiarze społecznym, gospodarczym i ochrony środowiska ma być realizowana zgodnie z koncepcją zrównoważonego i trwałego rozwoju. Dbałość o zasoby przyrody i wsparcie dla rozwoju przedsiębiorczości oraz aktywizacja ludności ma w konsekwencji przyczynić się do wzrostu poziomu i jakości życia mieszkańców ${ }^{9}$. Strategia rozwoju zrównoważonego utożsamiana jest tu z ekorozwojem uwzględniającym specyfikę fizyczno-geograficzną obszaru. Zadbane środowisko przyrodnicze uważane jest za warunek konieczny dla rozwoju społeczno-gospodarczego. Walory przyrodnicze i krajobrazowe Euroregionu stanowią jego potencjalny atut i czynnik wyróżniający ${ }^{10}$.

Euroregion Neisse-Nisa-Nysa również dąży do realizacji koncepcji trwałego i zrównoważonego rozwoju poprzez wszechstronne rozwijanie współpracy transgranicznej, promocję obszaru Euroregionu jako atrakcyjnego turystycznie, wspieranie działań priorytetowych związanych z poprawą stanu środowiska naturalnego, rozbudową infrastruktury technicznej i drogowej ${ }^{11}$.

\subsubsection{Kohezja gospodarcza, społeczna i ekologiczna}

W Euroregionie Pomerania w latach 2014-2020 podstawowym celem współpracy pozostaną działania mające na celu zwiększanie wzrostu gospodarczego i społecznego, walka z bezrobociem oraz zrównoważony rozwój transgranicznego obszaru. Priorytety działań pokrywają się ze Strategią Europa 2020 i należy do nich wzrost inteligentny, wzrost zrównoważony oraz wzrost sprzyjający włączeniu społecznemu.

7 Euroregion Pro Europa Viadrina, Koncepcja Rozwoju i Działania Viadrina 2007, Wersja z 27.06.2006, s. 23.

8 Umowa o utworzeniu Euroregionu Sprewa-Nysa-Bóbr, art. 2, pkt 1.

9 I. Rumianowska, Euroregionalny Program Rozwoju Zrównoważonego w Euroregionie Sprewa -Nysa-Bóbr, [w:] B. Fiedor, J. Rymarczyk (red.), Ekonomia i międzynarodowe stosunki gospodarcze, Wydawnictwo Akademii Ekonomicznej im. Oskara Langego, Wrocław 2007, s. 126-127.

10 G. Grzelak, Ekorozwój w Euroregionie "Sprewa-Nysa-Bóbr". Projekt Pilotażowy, Gubin 2000, s. 5.

11 Urząd Statystyczny we Wrocławiu, Czeski Urząd Statystyczny, Krajowy Urząd Statystyczny Saksonii, Rocznik Euroregionu Nysa, Wrocław-Liberec-Kamenz 2011, s. 20. 
W Euroregionie Pro Europa Viadrina podstawowym celem w zakresie zwiększania kohezji jest rozwój ducha przedsiębiorczości, wsparcie dla rozwoju małych i średnich przedsiębiorstw, działania mające na celu rozwój infrastruktury technicznej i drogowej oraz uwzględnienie turystyki jako sektora decydującego o poziomie rozwoju w regionie. Poprawa stanu środowiska naturalnego stanowi jeden z podstawowych priorytetów działania.

W Euroregionie Sprewa-Nysa-Bóbr zwiększanie spójności ma odbywać się poprzez podejmowanie wspólnych działań związanych z rozwojem gospodarki przestrzennej, przedsiębiorczości oraz poprawą stanu środowiska naturalnego. Ważną kwestią jest również podejmowanie transgraniczych działań mających na celu zapobieganie klęskom żywiołowym.

W Euroregionie Neisse-Nisa-Nysa celem podstawowym jest niwelowanie różnic w poziomie rozwoju regionu. Wśród celów szczegółowych jest rozwój planowania przestrzennego, rozwój przedsiębiorstw, poprawa poziomu i jakości życia mieszkańców oraz poprawa stanu środowiska naturalnego.

\subsubsection{Edukacja i świadomość ekologiczna}

Kierunek działań euroregionów jest zgodny ze Strategiq Lizbońską, której głównym przesłaniem są „inwestycje w młodzież, edukację, kształcenie zawodowe, badania i innowacje oraz podejmowanie koniecznych kroków w celu wykształcenia większej ilości wykwalifikowanej siły roboczej posiadającej ducha przedsiębiorczości”"12.

W Euroregionie Pomerania celem podejmowanych działań jest dopasowanie się do globalnych rynków, wykorzystanie branż przyszłościowych, tworzenie wspólnej polityki promocyjnej wspierającej inwestycje w Euroregionie. Celem jest podejmowanie współpracy transnarodowej pomiędzy przedsiębiorstwami, przemysłem a placówkami edukacyjno-badawczymi. W ramach rozwoju edukacji w Euroregionie podejmowane są działania mające na celu: wsparcie współpracy pomiędzy placówkami badawczymi w Euroregionie, promowanie nowych technologii, tworzenie klastrów wysokich technologii i urynkowienie wyników badań, rozbudowę współpracy pomiędzy szkołami wyższymi poprzez realizację wspólnych projektów naukowych i badawczych, podniesienie poziomu wykształcenia,

12 Mitteilung der Kommission an den Rat und das Europäische Parlament, Gemeinsame Maßnahmen für Wachstum und Beschäftigung: Das Lissabon-Programm der Gemeinschaft, KOM (330)2005, s. 3; Vorschlag für einen Beschluss des Europäischen Parlaments über das siebte Rahmenprogramm für Forschung, Technologie und Demonstration (2007-2013), 06.04.2005, KOM(119)2005 endgültig. 
wielojęzycznego kształcenia, podnoszenie kwalifikacji zawodowych i działań na rzecz elastyczności i mobilności zawodowej i regionalnej ${ }^{13}$.

Celem głównym współpracy w Euroregionie Pro Europa Viadrina jest pogłębianie współpracy partnerskiej w celu wykorzystania transgranicznych potencjałów. Jednym z priorytetowych celów jest wspieranie innowacyjności i edukacji. Do poszczególnych celów współpracy w dziedzinie edukacji należą: współpraca $\mathrm{w}$ dziedzinie nauki i badań rozwojowych oraz promocja nowych technologii ${ }^{14}$.

Celem Euroregionu Sprewa-Nysa-Bóbr jest rozwój Euroregionu jako konkurencyjnego i transgranicznego regionu gospodarczo-kulturowego. Celem w zakresie edukacji jest tematyczny rozwój edukacji i rozbudowa transferu technologii ${ }^{15}$.

W Euroregionie Neisse-Nisa-Nysa edukacja jest priorytetowym obszarem działania. Cele współpracy w zakresie edukacji obejmują w Euroregionie wszystkie poziomy, kierunki i formy nauczania oraz partnerstwo gmin i organizacji pozarządowych. Aktywność w sferze edukacji jest nie tylko misją, lecz także szansą rozwoju ${ }^{16}$. Wśród celów edukacyjnych wyróżnione zostały: wymiana informacji i doświadczeń w dziedzinie badań i nauki, organizacja seminariów naukowych dla pracowników naukowych i studentów, warsztaty naukowe zachęcające studentów do realizacji zadań badawczych, transfer kompetencji międzykulturowych, mobilność studentów, uczniów i pracowników naukowych, nauka języków obcych ${ }^{17}$.

\subsubsection{Rozwój przedsiębiorczości}

Jednym z priorytetowych obszarów współpracy w Euroregionie Pomerania jest „Rozwój i modernizacja gospodarki ze szczególnym uwzględnieniem MŚP”. Główne działania podejmowane w Euroregionie związane $\mathrm{z}$ funkcjonowaniem na jego obszarze podmiotów gospodarczych oscylują wokół utrzymania obecnych miejsc pracy i tworzenia nowych. Środkiem dla realizacji tego celu ma być wdrażanie zrównoważonych strategii innowacyjnych, koncentracja na wybranych branżach oraz wsparcie sektora małych i średnich przedsiębiorstw. Celem jest tworzenie szerszej sieci współpracy pomiędzy przedsiębiorstwami poprzez klastry oraz

13 Euroregion Pomerania, Transgraniczna koncepcja działań..., s. 129-135.

14 Euroregion Pro Europa Viadrina, Koncepcja Rozwoju i Działania Euroregionu Pro Europa Viadrina, 2014, s. 54.

15 Euroregion Sprewa-Nysa-Bóbr, Plan rozwoju i działania Euroregionu Sprewa-Nysa-Bóbr, http://euroregion-snb.pl/media/dokumenty/Ogolne/plan_rozwoju_i_dzialania_euroregionu_sprewa_nysa_bobr.pdf, s. 120-121 [dostęp 12.12.2014].

16 Euroregion Neisse-Nisa-Nysa, Edukacja i gospodarka. Uczyć się w Europie i dla Europy, http://www.neisse-nisa-nysa.org/index.php?id=69\&L=2 [dostęp 27.08.2013].

17 Urząd Statystyczny we Wrocławiu, Przedstawicielstwo Okręgowe w Libercu, Krajowy Urząd Statystyczny w Saksonii, Rocznik Euroregionu Nysa 2011, Wrocław-Liberec-Kamenz 2011, s. 27-28. 
ułatwienie dostępu do wysoko rozwiniętych usług dla przedsiębiorstw ${ }^{18}$. Istotnym zadaniem Euroregionu jest poprawienie sytuacji i warunków rozwoju sektora małych i średnich przedsiębiorstw poprzez organizację seminariów, wymianę informacji, wspólne badanie rynku czy planowania przestrzennego wspierającego rozwój infrastruktury techniczno-drogowej ${ }^{19}$.

Rozwój przedsiębiorczości silnie zaakcentowany został w Euroregionie Pro Europa Viadrina, gdzie jednym z podstawowych celów jest wspieranie turystycznych i gospodarczych atutów lokalizacji. Realizacja celu ma się odbywać poprzez podejmowanie działań zmierzających do: rozwoju wspólnych struktur i tworzenia strategii rozwoju, rozwoju turystyki w Euroregionie, rozbudowy szlaków turystycznych oraz infrastruktury technicznej, efektywnego wykorzystania walorów środowiska przyrodniczego i elementów krajobrazu, wsparcia i rozwoju transgranicznej współpracy pomiędzy przedsiębiorstwami, promocji gospodarczej, włączenia przedsiębiorstw do transgranicznej sieci komunikacyjnej ${ }^{20}$. Działania zmierzające do rozwoju przedsiębiorczości w Euroregionie Pro Europa Viadrina wspierane są przez podnoszenie kwalifikacji zawodowych, promowanie regionalnych produktów i wyrobów, tworzenie ram instytucjonalno-prawnych dla powstawania przedsiębiorstw transgranicznych, wsparcie dla sieci polsko-niemieckich przedsiębiorstw, rozwój małych i średnich przedsiębiorstw oraz tworzenie tzw. business cluster dla podmiotów gospodarczych działających w podobnych branżach ${ }^{21}$.

Rozwój gospodarczy jest jednym z celów Euroregionu Sprewa-Nysa-Bóbr, ma on być zrealizowany poprzez wzmocnienie obecnie funkcjonujących podmiotów gospodarczych i głównych branż w Euroregionie. Konieczne jest również stworzenie rozbudowanych sieci regionalnych. Do priorytetowych celów związanych $z$ rozwojem gospodarczym zaliczono: tworzenie i rozbudowę już istniejącej transgranicznej infrastruktury drogowej i technologicznej, efektywne wykorzystanie struktury przestrzennej, poprawę połączeń drogowych i kolejowych pomiędzy ośrodkami miejskimi w euroregionie, zapewnienie wykwalifikowanej kadry pracowniczej, poprawę instytucjonalnych uwarunkowań prowadzenia działalności gospodarczej, rozbudowę transferu technologii ${ }^{22}$.

Euroregion Neisse-Nisa-Nysa, podejmując działania w zakresie rozwoju gospodarki, koncentruje się na zmniejszeniu wad wynikających z przygranicznego położenia. Konieczne według władz Euroregionu są wspólne działania w zakresie badań produktów, zdobywania nowych rynków zbytu czy racjonalnego wyko-

18 http://www.pomerania.net/download/EHK_POMERANIA_2007-13_Endfassung_PL.pdf, s. 109 [dostęp 12.04.2014].

19 http://www.pomerania.net/main.cfm?l=pl\&rubrik=5\&th=31 [dostęp 10.10.2014].

20 Euroregion Pro Europa Viadrina, Koncepcja Rozwoju..., s. 47.

21 Ibidem, s. 50.

22 http://euroregionsnb.pl/media/dokumenty/Ogolne/plan_rozwoju_i_dzialania_euroregio nu_sprewa_nysa_bobr.pdf, s. 120-121 [dostęp 10.10.2014]. 
rzystania istniejących zasobów. Wzrost konkurencyjności powinien odbywać się poprzez: skupienie się na centralnych obszarach działań, określenie kluczowych branż dla rozwoju gospodarczego, strategiczne pozycjonowanie w kierunku biegunów wzrostu i europejskich centrów gospodarczych ${ }^{23}$.

\subsubsection{Racjonalne wykorzystanie zasobów środowiska naturalnego}

Współpraca w Euroregionie Pomerania w zakresie ochrony środowiska naturalnego ma na celu uzgadnianie i harmonizację wspólnych działań dla zachowania naturalnego potencjału regionu. Zasada trwałości ekologicznej połączona jest ze wsparciem alternatywnych gałęzi transportu dla przeciwważenia transportu drogowego. Ochrona środowiska naturalnego w Euroregionie Pomerania jest jednym z priorytetów jego działania. W priorytecie C „Środowisko” wspierane są: „działania na rzecz zachowania przyrody i krajobrazu, konserwacji krajobrazu w celu zachowania atrakcyjności krajobrazu kulturowego regionu. Elementem są tutaj również ochrona przed klęskami żywiołowymi, ochrona przed awariami przemysłowymi i ochrona przeciwpowodziowa" 24 .

Dbanie o środowisko naturalne uwzględnione zostało jako jeden $\mathrm{z}$ głównych celów w Euroregionie Pro Europa Viadrina. Cel ten uwzględnia również rozwój wspólnej infrastruktury i określany jest mianem „Wspólna infrastruktura i ochrona środowiska naturalnego". Wśród zadań związanych z ochroną zasobów przyrody wyróżniono: rozwój i stworzenie sieci między regionalnymi organizacjami ekologicznymi, koncepcję integracji odnawialnych źródeł energii do systemów energetycznych, współpracę instytucji w zakresie zaopatrzenia w wodę pitną, gospodarki odpadami, systemów energetycznych i oczyszczania, rozwój i dalsze działania na rzecz ochrony przeciwpożarowej i zapobiegania katastrofom, działania na rzecz ochrony przed emisjami i poprawę jakości życia mieszkańców euroregionu ${ }^{25}$.

Celem nadrzędnym Euroregionu Sprewa-Nysa-Bóbr w zakresie ochrony zasobów przyrody jest sanacja ekologiczna jego terytorium. Do celów pośrednich zaliczono: współdziałanie polskich i niemieckich podmiotów działalności komunalnej i harmonizację ich działań, podejmowanie wspólnych działań w zapobieganiu

23 H. Grosse, Euroregion Neisse-Nisa-Nysa na drodze do wspólnej przestrzeni gospodarczej, [w:] M. Zdulski (red.), 20 lat współpracy transgranicznej w Euroregionie Neisse-Nysa-Nisa, Wydawnictwo Ad Rem, Jelenia Góra 2011, s. 21.

24 Transgraniczna koncepcja działań i rozwoju Euroregionu Pomerania na lata 2007-2013, s. 57-62.

25 Koncepcja Rozwoju i Działania Euroregionu Pro Europa Viadrina 2014, Gorzów Wielkopolski -Frankfurt (Oder) 2013, s. 23. 
i zwalczaniu klęsk żywiołowych. Wszelkie działania o charakterze gospodarczym powinny iść $\mathrm{w}$ parze $\mathrm{z}$ dbałością o środowiska naturalne ${ }^{26}$.

Problemy ochrony środowiska naturalnego są ważnym elementem strategii i funkcjonowania Euroregionu Neisse-Nisa-Nysa. Eksperci polscy, czescy i niemieccy rozwiązują problemy transgraniczne $\mathrm{w}$ ramach istniejących grup roboczych. Trzy z 17 grup roboczych skupiają się na funkcjonowaniu środowiska naturalnego. Celem „Grupy Lasy” jest współpraca nadleśnictw i ekspertów ds. środowiska naturalnego i rozwiązywanie aktualnych problemów związanych z ochroną zasobów przyrody. W ramach „Grupy Woda - Czysta Nysa” rozwiązywane są problemy związane z zanieczyszczeniem powietrza, wody, odpadami komunalnymi. Celem jest budowa oczyszczalni ścieków oraz zapobieganie klęskom żywiołowym i zwalczanie ich skutków oraz tworzenie odpowiedniej infrastruktury wodno-ściekowej. W ramach „Grupy Zarządzanie Kryzysowe” rozwiązywane są problemy związane $\mathrm{z}$ walką z zagrożeniami i katastrofami przekraczającymi granice państwowe. Celem są również działania mające na celu współpracę i wzajemne programy szkoleniowe dla jednostek straży pożarnej ${ }^{27}$.

\subsection{Analiza potencjału rozwojowego euroregionów}

Ocena mocnych i słabych stron rozwoju euroregionów pozwala na określenie szans i zagrożeń dla ich przyszłego rozwoju. Dla potrzeb niniejszej pracy analiza SWOT zaprezentowana została dla całego zachodniego pogranicza Polski. Należy nadmienić, że w literaturze przedmiotu oraz opracowaniach tworzonych przez euroregiony można znaleźć analizy potencjału dla każdej jednostki oddzielnie ${ }^{28}$. Wydaje się jednak, że obszar transgraniczny pomiędzy Polską i Niemcami jest stosunkowo jednorodny, a warunki jego rozwoju w znacznej mierze uzależnione są od poziomu współpracy pomiędzy tymi dwoma krajami.

26 Umowa o utworzeniu Euroregionu Sprewa-Nysa-Bóbr zawarta między stowarzyszeniem Gmin Rzeczpospolitej Polskiej Euroregion Sprewa-Nysa-Bóbr a Stowarzyszeniem Euroregion-Sprewa-Bóbr, art. 2, pkt 1.

27 http://www.stat.gov.pl/cps/rde/xbcr/wroc/ASSETS_Rocznik_Euroregionu_Nysa_2011.pdf [dostęp 11.11.2014], s. 25-30.

28 Opracowanie własne na podstawie: J. Szlachta, W. Dziemianowicz, P. Nowicka, Założenia Strategii Rozwoju Polski Zachodniej, GEOPROFIT, Wrocław-Opole-Gorzów Wielkopolski -Szczecin 2012, s. 20-22; T. Kudłacz, P. Lityński, Analiza pięciu strategii regionalnych województw Polski zachodniej i problemów stykowych pomiędzy województwami Polski zachodniej z innymi regionami, https://www.polskawschodnia.2007-2013.gov.pl/analizyraportypodsumowania/documents/kudlacz.pdf, s. 46-53 [dostęp 12.04.2015]. 
Tabela 6.1. Analiza SWOT euroregionów zachodniego pogranicza Polski

Mocne strony euroregionów położonych na zachodniej granicy Rzeczpospolitej

- dogodne położenie geograficzne wzdłuż rzeki Odry spajającej przestrzeń społeczno-gospodarczą i przyrodniczą,

- zachodnia granica oddziela Polskę od Niemiec będących jednym z najlepiej rozwiniętych państw świata i liderem w Unii Europejskiej,

- w euroregionach i w ich sąsiedztwie występują wysoko rozwinięte metropolie będące głównymi ośrodkami życia społeczno-gospodarczego i kulturalnego,

- rozwinięty przemysł przetwórczy, energetyczny i wydobywczy,

- wysoki poziom aktywności społecznej i sektora małych i średnich przedsiębiorstw, w szczególności w nawiązywaniu kontaktów z Niemcami,

- występowanie firm, organizacji i instytucji mających doświadczenie w nawiązywaniu kontaktów biznesowych z podmiotami niemieckimi,

- poparcie władz politycznych na szczeblu rządowym i samorządowym dla rozwoju Polski Zachodniej,

- występowanie dobrze rozbudowanej sieci połączeń ponadregionalnych, lądowisk, portów,

- duży udział usług w strukturze gospodarki i wysoki stopień kooperacji przedsiębiorstw,

- rosnący popytu na usługi turystyczne przy jednoczesnym wzroście świadomości i konieczności ochrony środowiska naturalnego,

- realizacja projektów polsko-niemieckich dotyczących rozwoju edukacji i przystosowania do nowych warunków pracy,

- dobrze rozwinięta sieć szkół wyższych,

- występowanie bogatej fauny i flory, duża gęstość lasów i występowanie parków ochrony przyrody.

Słabe strony euroregionów położonych na zachodniej granicy Rzeczpospolitej

- niska spójność komunikacyjna i istotne braki w infrastrukturze drogowej, kolejowej i wykorzystaniu Odry jako węzła komunikacyjnego,

- wysoki poziom polaryzacji w największych ośrodkach miejskich,

- niski poziom produktywności w sferze usług,

- starzenie się społeczeństwa,

- znaczne różnice potencjałów rozwojowych poszczególnych ośrodków edukacyjnych,

- niski poziom innowacyjności przemysłu i infrastruktury technicznej,

- zbyt mały poziom nakładów ponoszonych na innowacyjność, badania i rozwój,

- brak odpowiedniej ilości przejść granicznych na rzekach,

- występowanie regionów tranzytowych,

- brak lokalnej komunikacji transgranicznej,

- stosunkowo słabo rozwinięta szeroko rozumiana infrastruktura społeczna w dziedzinie opieki zdrowia (szczególnie po polskiej stronie),

- duże różnice w poziomie rozwoju i poziomu życia obywateli poszczególnych krajowych części euroregionów,

- niski poziom tzw. transgranicznych produktów turystycznych,

- duże bezrobocie, szczególnie widoczne wśród osób młodych,

- wysoki poziom wydobycia węgla brunatnego destrukcyjnie wpływający na środowisko naturalne i poziom ochrony środowiska naturalnego. 
Tabela 6.1. (cd.)

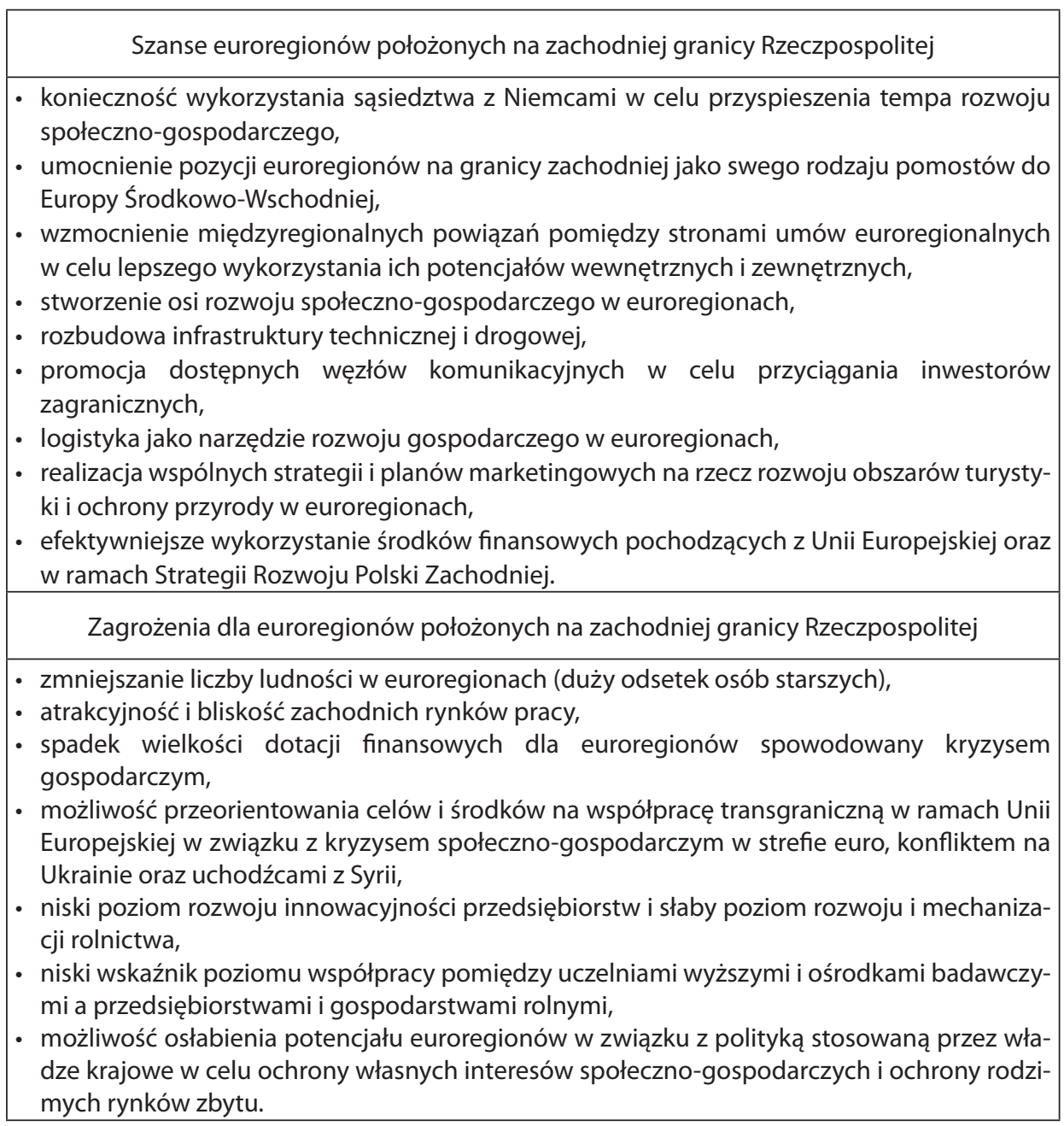

Źródło: opracowanie własne na podstawie: Strategia zrównoważonego rozwoju Euroregionów zachodniego pogranicza Polski na lata 2014-2020.

\subsection{Ocena spójności społecznej, gospodarczej i ekologicznej w euroregionach}

Spójność społeczno-gospodarcza zgodnie z definicją zawartą w art. 158 Traktatu WE jest niezbędna dla "harmonijnego rozwoju całej Wspólnoty” i wymaga zmniejszenia „dysproporcji w poziomach rozwoju różnych regionów”, tzn. „za- 
cofania regionów najmniej uprzywilejowanych"29. Miernikiem spójności gospodarczej jest wskaźnik PKB per capita wyznaczany według parytetu siły nabywczej poszczególnych walut, spójności społecznej stopa bezrobocia a spójności terytorialnej peryferyjność położenia i dostępność ośrodków miejskich ${ }^{30}$.

\section{Spójność ekonomiczna}

Analizując wskaźniki PKB per capita w Euroregionie Pomerania, można zauważyć wyraźną różnicę w poziomie spójności gospodarczej w poszczególnych częściach Euroregionu. Najwyższy wskaźnik poziomu PKB per capita występuje w szwedzkiej części Euroregionu, natomiast najniższy - w części polskiej. Dochód narodowy jest czterokrotnie wyższy w części szwedzkiej w porównaniu z częścią polską. Średni dochód na jednego mieszkańca w całym Euroregionie Pomerania waha się od 16383 euro w 2000 r. do poziomu 22532 euro w 2014 r., można więc zauważyć trend wzrostowy. Porównując wskaźniki PKB per capita do średnich krajowych, można zauważyć, że w polskiej części Euroregionu dochód na jednego mieszkańca jest niższy od średniej krajowej w Polsce. Sytuacja wygląda podobnie w części niemieckiej i szwedzkiej. Jest to naturalna konsekwencja peryferyjnego położenia wzdłuż granicy państw.

W Euroregionie Pomerania najlepiej rozwiniętą częścią pod względem poziomu wskaźnika PKB per capita jest część szwedzka, choć i tutaj poziom rozwoju jest niższy od średniego wskaźnika dochodu na jednego mieszkańca w Szwecji.

Tabela 6.2. PKB per capita w Euroregionie Pomerania (w cenach bieżących: euro)

\begin{tabular}{|c|c|c|c|c|c|c|c|}
\hline \multirow{2}{*}{ Lata } & \multirow{2}{*}{$\begin{array}{c}\text { Część } \\
\text { niemiecka }\end{array}$} & \multirow{2}{*}{$\begin{array}{c}\text { Czesść } \\
\text { polska }\end{array}$} & \multirow{2}{*}{$\begin{array}{c}\text { Część } \\
\text { szwedzka }\end{array}$} & \multirow{2}{*}{$\begin{array}{l}\text { Euroregion } \\
\text { Pomerania }\end{array}$} & \multicolumn{3}{|c|}{ PKB per capita wg cen bieżących } \\
\cline { 6 - 9 } & & & & & Polska & Szwecja & Niemcy \\
\hline 2000 & 16650 & 4900 & 27600 & 16383 & 4900 & 30200 & 24900 \\
\hline 2008 & 17900 & 4900 & 28900 & 17233 & 5300 & 32400 & 26600 \\
\hline 2012 & 20700 & 8600 & 31600 & 20300 & 9500 & 36100 & 30100 \\
\hline 2014 & 23470 & 8579 & 33723 & 21557 & 10083 & 39183 & 31871 \\
\hline
\end{tabular}

Źródło: opracowanie własne na podstawie: Aktualizacja koncepcji rozwoju Euroregionu Pomerania na lata 2014-2020, s. 54-57; Urząd Statystyczny we Wrocławiu, Euroregiony na granicach Polski 2007, Wrocław 2007, s. 44-50; Eurostat; dane z Sekretariatu Euroregionu Pomerania.

29 J.Witkowska, Spójność społeczno-gospodarcza Unii Europejskiej-pozycja Polski i jej regionów, „Problemy Zarządzania”, vol. 8, nr 1(27)/2010, s. 76.

30 M. Greta, K. Lewandowski, Euroregion jako instrument realizacji spójności społeczno-ekonomicznej i Strategii Lizbońskiej, ',Czasopisma Uniwersytetu Rzeszowskiego”, z. 12/2008, s. 72. 
Jeszcze większą dysproporcję widać w części niemieckiej, gdzie PKB na jednego mieszkańca w 2014 r. wyniosło 23404 euro, a PKB per capita dla Niemiec wyniósł 33088 euro. Zatem średni poziom wskaźnika w części niemieckiej Euroregionu był niższy o 1,4 razy w porównaniu ze średnim poziomem wskaźnika dla Niemiec. W Euroregionie Pro Europa Viadrina można zauważyć podobną tendencję.

Tabela 6.3. PKB per capita $w$ Euroregionie Pro Europa Viadrina (w cenach bieżących: euro)

\begin{tabular}{|c|c|c|c|}
\hline Lata & Część niemiecka & Część polska & $\begin{array}{c}\text { Euroregion Pro Europa } \\
\text { Viadrina }\end{array}$ \\
\hline 2000 & 16900 & 4600 & 10750 \\
\hline 2004 & 18200 & 4800 & 11500 \\
\hline 2008 & 21000 & 8400 & 14700 \\
\hline 2012 & 22738 & 8578 & 15658 \\
\hline 2014 & 23793 & 9297 & 16545 \\
\hline
\end{tabular}

Źródło: opracowanie własne na podstawie: Koncepcja rozwoju i działania Euroregionu Pro Europa Viadrina, s. 10-13; Urząd Statystyczny we Wrocławiu, Euroregiony na granicach Polski 2007, Wroctaw 2007, s. 57-66; dane z Sekretariatu Euroregionu Pro Europa Viadrina.

Poziom rozwoju części polskiej jest niższy w porównaniu z częścią niemiecką. Jednocześnie średni poziom PKB per capita dla Euroregionu Pro Europa Viadrina wzrastał w analizowanym okresie z poziomu 10750 do poziomu 16545 euro. Wzrost poziomu wskaźnika widoczny jest w całym analizowanym okresie. W 2014 r. w części niemieckiej dochód na jednego mieszkańca wyniósł 23793 euro, po stronie polskiej 9297 euro. Oznacza to, że po stronie niemieckiej był 2,6 razy wyższy niż po stronie polskiej.

Tabela 6.4. PKB per capita w Euroregionie Sprewa-Nysa-Bóbr (w cenach bieżących: euro)

\begin{tabular}{|c|c|c|c|}
\hline Lata & Część niemiecka & Część polska & $\begin{array}{c}\text { Euroregion Sprewa } \\
- \text { Nysa-Bóbr }\end{array}$ \\
\hline 2000 & 16900 & 4750 & 10825 \\
\hline 2004 & 18200 & 5200 & 11700 \\
\hline 2008 & 21000 & 9050 & 15025 \\
\hline 2012 & 22738 & 9573 & 16156 \\
\hline 2014 & 23793 & 10441 & 17117 \\
\hline
\end{tabular}

Źródło: opracowanie własne na podstawie: Plan działania i rozwoju Euroregionu Sprewa-Nysa -Bóbr na lata 2014-2020, s. 68-71; Urząd Statystyczny we Wrocławiu, Euroregiony na granicach Polski 2007, Wrocław 2007, s. 67-76; dane z Sekretariatu Euroregionu Sprewa-Nysa-Bóbr. 
W latach 2000-2014 dochód na jednego mieszkańca w Euroregionie Sprewa-Nysa-Bóbr wzrastał z poziomu 10825 euro do poziomu 17117 euro, co daje wzrost o 1,6 wskaźnika w badanym okresie. Jednocześnie należy zauważyć, że poziom rozwoju po stronie polskiej jest niższy niż po stronie niemieckiej. Należy jednak nadmienić, że dynamika wzrostu poziomu wskaźnika jest wyższa po stronie polskiej, gdzie zanotowano jego 2-krotny wzrost pomiędzy 2000 a $2014 \mathrm{r}$.

Na końcu analizowanego okresu poziom PKB per capita w niemieckiej części Euroregionu wyniósł 23793 euro, a w części polskiej 10441 euro. Oznacza to, że w części niemieckiej jest 2,3 razy wyższy niż w polskiej części Euroregionu.

Najwyższy wskaźnik PKB per capita w Euroregionie Neise-Nisa-Nysa występuje w jego niemieckiej części. W okresie od 2000 r. wzrósł on z poziomu 16700 do poziomu 24758 euro na jednego mieszkańca w 2014 r. W czeskiej i polskiej części Euroregionu dochód na jednego mieszkańca jest zbliżony. Wzrastał on odpowiednio w latach 2000-2014 z poziomu 5600 do 14532 euro w czeskiej części, a w polskiej z poziomu 5000 euro w 2000 r. do poziomu 12434 euro w $2014 \mathrm{r}$. Najniższy poziom PKB per capita, podobnie jak w przypadku pozostałych euroregionów, występuje po stronie polskiej. Jednocześnie można zauważyć trend rosnący wskaźnika PKB per capita od roku 2004, a więc od daty przystąpienia Polski i Czech do Unii Europejskiej.

Tabela 6.5. PKB per capita (euro) w Euroregionie Neisse-Nisa-Nysa

\begin{tabular}{|c|c|c|c|c|}
\hline Lata & Część czeska & Część niemiecka & Część polska & $\begin{array}{c}\text { Euroregion Neisse } \\
\text {-Nisa-Nysa }\end{array}$ \\
\hline 2000 & 5600 & 16700 & 5000 & 9100 \\
\hline 2004 & 7600 & 19200 & 5400 & 10733 \\
\hline 2008 & 12000 & 21800 & 10200 & 14667 \\
\hline 2012 & 13256 & 23630 & 11271 & 16053 \\
\hline 2014 & 14532 & 24758 & 12434 & 17241 \\
\hline
\end{tabular}

Źródło: opracowanie własne na podstawie: Strategia rozwoju Euroregionu Neisse-Nisa-Nysa na lata 2014-2020, s. 30-32, Urząd Statystyczny we Wrocławiu, Euroregiony na granicach Polski 2007, Wrocław 2007, s. 77-87; dane z Sekretariatu Euroregionu Neisse-Nisa-Nysa.

Dokonując analizy porównawczej wskaźnika PKB per capita w euroregionach na granicy zachodniej, można zauważyć, że podobne wartości przyjmuje on dla wszystkich euroregionów. Najbardziej zbliżone wyniki zanotowano w Euroregionie Pro Europa Viadrina, Sprewa-Nysa-Bóbr i w Euroregionie Neisse-Nisa-Nysa. Najwyższy poziom wskaźnika występuje w Euroregionie Pomerania. Analizując średnie wartości wskaźnika PKB w euroregionach, można zauważyć, że są one niższe od przeciętnych wskaźników dla Niemiec, porównywalne zaś z wynikami Czech i wyższe od wskaźników dla Polski. 


\section{Spójność społeczna}

Wyznacznikiem spójności społecznej jest stopa bezrobocia. W Euroregionie Pomerania w latach 2000-2014 stopa bezrobocia spadała z poziomu 14,7 do 8,6\%.

Tabela 6.6. Stopa bezrobocia w Euroregionie Pomerania (\%)

\begin{tabular}{|c|c|c|c|c|c|c|c|}
\hline \multirow{2}{*}{ Lata } & \multirow{2}{*}{$\begin{array}{c}\text { Część } \\
\text { niemiecka }\end{array}$} & \multirow{2}{*}{$\begin{array}{c}\text { Część } \\
\text { polska }\end{array}$} & \multirow{2}{*}{$\begin{array}{c}\text { Część } \\
\text { szwedzka }\end{array}$} & \multirow{2}{*}{$\begin{array}{c}\text { Euroregion } \\
\text { Pomerania }\end{array}$} & \multicolumn{3}{|c|}{ Średnia stopa bezrobocia } \\
\cline { 6 - 8 } & & & Niemcy & Polska & Szwecja \\
\hline 2000 & 16,35 & 20,4 & 7,3 & $\mathbf{1 4 , 7}$ & 7,9 & 16,3 & 5,5 \\
\hline 2004 & 20,65 & 23,8 & 8,3 & $\mathbf{1 7 , 6}$ & 10,7 & 19,1 & 6,7 \\
\hline 2008 & 13,10 & 9,5 & 7,4 & $\mathbf{1 0 , 0}$ & 7,5 & 7,1 & 6,2 \\
\hline 2012 & 9,55 & 10,9 & 9,4 & $\mathbf{1 0 , 0}$ & 5,5 & 10,1 & 8,0 \\
\hline
\end{tabular}

Źródło: opracowanie własne na podstawie danych z Sekretariatu Euroregionu Pomerania.

Najniższy wskaźnik odnotowywano w szwedzkiej części Euroregionu, gdzie średnia stopa bezrobocia w całym okresie wynosiła niespełna $8 \%$, natomiast najwyższy w części polskiej, gdzie średnio wskaźnik wynosił 16,8\%. Cieszy, że po stronie polskiej stopa bezrobocia w całym okresie spadła wyraźnie z poziomu $20,4 \%$ do poziomu $8,4 \%$.

Ważną rolę w jej spadku odegrało przystąpienie Polski do Unii Europejskiej i możliwość szerszej współpracy z Niemcami. Stopa bezrobocia w niemieckiej części Euroregionu również spadała, należy jednak zauważyć, że niemiecki obszar przygraniczny jest obszarem peryferyjnym, a poziom stopy bezrobocia jest zdecydowanie wyższy od średniej wartości wskaźnika dla Niemiec. Jednocześnie poziom stopy bezrobocia nieznacznie wzrósł w części szwedzkiej Euroregionu. W roku 2014 przeciętna stopa bezrobocia w Euroregionie Pomerania wyniosła 8,6\%.

Stopa bezrobocia w Euroregionie Pro Europa Viadrina w badanym okresie spadała z poziomu 18,6\% w roku 2000 do 7,5\% w 2014 r., co stanowi dwukrotny spadek. Po stronie polskiej stopa bezrobocia jest nieznacznie wyższa w porównaniu z niemiecką. W 2014 r. w części niemieckiej wyniosła 6,7\%, a po stronie polskiej $-8,35 \%$.

Tabela 6.7. Stopa bezrobocia w Euroregionie Pro Europa Viadrina (\%)

\begin{tabular}{|c|c|c|c|}
\hline Lata & Część niemiecka & Część polska & Euroregion Pro Europa Viadrina \\
\hline 2000 & 16,3 & 20,9 & $\mathbf{1 8 , 6}$ \\
\hline 2004 & 19,2 & 24,4 & $\mathbf{2 1 , 8}$ \\
\hline 2008 & 11,5 & 8,0 & $\mathbf{9 , 8}$ \\
\hline 2012 & 8,3 & 10,0 & $\mathbf{9 , 1}$ \\
\hline 2014 & 6,7 & 8,35 & $\mathbf{7 , 5}$ \\
\hline
\end{tabular}

Źródło: opracowanie własne na podstawie danych z Sekretariatu Euroregionu Pro Europa Viadrina. 
Stopa bezrobocia w Euroregionie Sprewa-Nysa-Bóbr spadła z poziomu 17\% w 2000 r. do 7,4\% w roku 2014. Wskaźnik stopy bezrobocia w całym analizowanym okresie po stronie polskiej i niemieckiej był na zbliżonym poziomie.

Tabela 6.8. Stopa bezrobocia w Euroregionie Sprewa-Nysa-Bóbr (\%)

\begin{tabular}{|c|c|c|c|}
\hline Lata & Część niemiecka & Część polska & Euroregion Sprewa-Nysa-Bóbr \\
\hline 2000 & 16,3 & 17,70 & $\mathbf{1 7 , 0}$ \\
\hline 2004 & 19,2 & 21,05 & $\mathbf{2 0 , 1}$ \\
\hline 2008 & 11,5 & 6,30 & $\mathbf{8 , 9}$ \\
\hline 2012 & 8,3 & 8,75 & $\mathbf{8 , 5}$ \\
\hline 2014 & 6,7 & 8,00 & $\mathbf{7 , 4}$ \\
\hline
\end{tabular}

Źródło:opracowanie własne na podstawie danych z Sekretariatu Euroregionu Sprewa-Nysa-Bóbr.

Poziom bezrobocia w niemieckiej części Euroregionu był wyższy od średniego wskaźnika dla Niemiec. W 2014 r. stopa bezrobocia wynosiła w części niemieckiej 6,7\%, a w części polskiej - 8\%. Bezrobocie w polskiej części Euroregionu Sprewa -Nysa-Bóbr było zatem nieznacznie niższe w 2014 r. w porównaniu ze średnią dla Polski.

W Euroregionie Neisse-Nisa-Nysa również można zauważyć spadek stopy bezrobocia z poziomu 15,2\% w 2000 r. do 7,5\% w roku 2014.

Tabela 6.9. Stopa bezrobocia w Euroregionie Neisse-Nisa-Nysa (\%)

\begin{tabular}{|c|c|c|c|c|c|}
\hline Lata & Część czeska & Część niemiecka & Część polska & $\begin{array}{c}\text { Euroregion } \\
\text { Neisse-Nisa } \\
-\mathbf{N y s a}\end{array}$ & Czechy \\
\hline 2000 & 6,8 & 16,1 & 22,6 & $\mathbf{1 5 , 2}$ & 8,8 \\
\hline 2004 & 6,7 & 19,4 & 26,7 & $\mathbf{1 7 , 6}$ & 8,2 \\
\hline 2008 & 4,0 & 12,9 & 9,1 & $\mathbf{8 , 7}$ & 4,4 \\
\hline 2012 & 8,0 & 8,2 & 11,1 & $\mathbf{9 , 1}$ & 7,0 \\
\hline 2014 & 6,3 & 7,2 & 9,1 & $\mathbf{7 , 5}$ & 6,1 \\
\hline
\end{tabular}

Źródło: opracowanie własne na podstawie danych z Sekretariatu Euroregionu Neisse-Nisa-Nysa.

Najwyższy poziom bezrobocia występuje po stronie polskiej, najniższy zaś po stronie czeskiej. W latach 2000-2014 stopa bezrobocia po stronie polskiej spadła dwukrotnie, podobna tendencja spadkowa miała miejsce w części niemieckiej, zaś w części czeskiej stopa bezrobocia w badanym okresie utrzymywała się na podobnym poziomie. W każdej z części Euroregionu Neisse-Nisa-Nysa poziom stopy bezrobocia jest wyższy od średniej stopy bezrobocia w poszczególnych krajach, jednak nie są to zasadnicze różnice.

Dokonując oceny spójności społecznej w euroregionach mierzonej za pomocą wskaźnika stopy bezrobocia, można zauważyć, że w każdym z euroregionów poziom bezrobocia spadał. $\mathrm{W}$ ostatnim okresie jest on na zbliżonym poziomie do 
wskaźników bezrobocia dla całych krajów. Najniższy wskaźnik stopy bezrobocia odnotowano w Euroregionie Sprewa-Nysa-Bóbr, najwyższy zaś - w Euroregionie Pomerania. Podsumowując, spójność społeczna mierzona za pomocą stopy bezrobocia zwiększa się, co może oznaczać, że współpraca w euroregionach przynosi pozytywne rezultaty.

\section{Spójność ekologiczna w euroregionach}

Spójność ekologiczna jest niezwykle ważną miarą świadczącą o rozwoju danego regionu z uwzględnieniem poszanowania zasobów przyrody. Zmierzenie spójności ekologicznej w regionach jest trudne, gdyż wymaga szerszego spojrzenia na problematykę ochrony środowiska naturalnego. Problemem jest tu w szczególności dostęp do danych związanych z ochroną środowiska naturalnego. Dla potrzeb niniejszej monografii dane związane z postępem spójności ekologicznej opisane zostały w oparciu o zasoby Eurostatu i ich dostępność dla poszczególnych euroregionów na zachodniej granicy Polski.

Jedną z dostępnych miar pozwalającą wyznaczyć wartości dla wszystkich czterech euroregionów jest wskaźnik generowania odpadów komunalnych. Brak danych spowodował, że dla Euroregionu Pomerania dane wyznaczone zostały jedynie dla części niemieckiej i polskiej.

Tabela 6.10. Wskaźnik generowania odpadów komunalnych w euroregionach (1 000 t)

\begin{tabular}{|c|c|c|c|c|}
\hline Lata & Pomerania & Pro Europa Viadrina & Sprewa-Nysa-Bóbr & Neisse-Nisa-Nysa \\
\hline 2004 & 747,5 & 598,2 & 756,3 & 827,2 \\
\hline 2008 & 749,3 & 638,3 & 798,4 & 835,0 \\
\hline 2012 & 739,3 & 631,6 & 801,1 & 829,8 \\
\hline 2014 & 776,1 & 668,9 & 833,4 & 686,5 \\
\hline
\end{tabular}

Źródło: opracowanie własne na podstawie danych z Eurostat.

Analizując wskaźnik generowania odpadów komunalnych w euroregionach na zachodniej granicy Polski, można zauważyć, że po roku 2004 w Euroregionach Pomerania, Pro Europa Viadrina i Sprewa-Nysa-Bóbr mamy do czynienia ze wzrostem wskaźnika generowania odpadów komunalnych. W Euroregionie Pomerania w roku 2004 wynosił on 747,5 tys. ton, a w 2014 r. 776,1 tys. ton, w Euroregionie Sprewa-Nysa-Bóbr wzrósł z poziomu 756,3 do 833,4 tys. ton, w Euroregionie Pro Europa Viadrina wzrósł z poziomu 598,2 do 668,9 tys. ton. Natomiast w Euroregionie Neisse-Nisa-Nysa na przestrzeni lat 2004-2014 wskaźnik spadł z poziomu 827,2 do 686,5 tys. ton.

Dokonując analizy danych odnośnie recyklingu w euroregionach, można zauważyć pozytywne efekty działań podejmowanych w zakresie ochrony środowiska naturalnego. W latach 2004-2014 w każdym euroregionie nastąpił wzrost liczby materiałów poddanych recyklingowi. 
W latach 2004-2014 ilość materiałów poddanych recyklingowi wzrosła w Euroregionie Pomerania o 463,1 tys. ton, w Euroregionie Sprewa-Nysa-Bóbr o 512,4 tys. ton, w Euroregionie Pro Europa Viadrina o 410,5 tys. ton, a w Euroregionie Neisse-Nisa-Nysa o 301,28 tys. ton.

Tabela 6.11. Materiały poddane recyklingowi (tys. ton)

\begin{tabular}{|c|c|c|c|c|}
\hline Lata & $\begin{array}{c}\text { Euroregion } \\
\text { Pomerania }\end{array}$ & $\begin{array}{c}\text { Euroregion Sprewa } \\
\text {-Nysa-Bóbr }\end{array}$ & $\begin{array}{c}\text { Euroregion Pro } \\
\text { Europa Viadrina }\end{array}$ & $\begin{array}{c}\text { Euroregion } \\
\text { Neisse-Nisa-Nysa }\end{array}$ \\
\hline 2004 & 679,3 & 400,2 & 387,9 & 388,8 \\
\hline 2008 & 864,1 & 622,8 & 584,4 & 567,6 \\
\hline 2012 & 1028,7 & 783,4 & 697,7 & 597,3 \\
\hline 2014 & 1142,4 & 912,6 & 798,4 & 690,1 \\
\hline
\end{tabular}

Źródło: opracowanie własne na podstawie danych z Sekreatariatów Euroregionów oraz Eurostat.

W euroregionach można dostrzec również poprawę dostępności do publicznych zasobów wody pitnej. Należy nadmienić, że poziom dostępu do wody w niemieckich i szwedzkich częściach euroregionów wynosił po roku 2000 niespełna $100 \%$. Gorzej sytuacja wyglądała w przypadku części polskiej i czeskiej. W Euroregionie Pomerania w 2011 r. dostęp do wody pitnej wynosił 96\%, w Euroregionie Neisse-Nisa-Nysa 95\%, a w Euroregionach Sprewa Nysa Bóbr i Pro Europa Viadrina po $94 \%$.

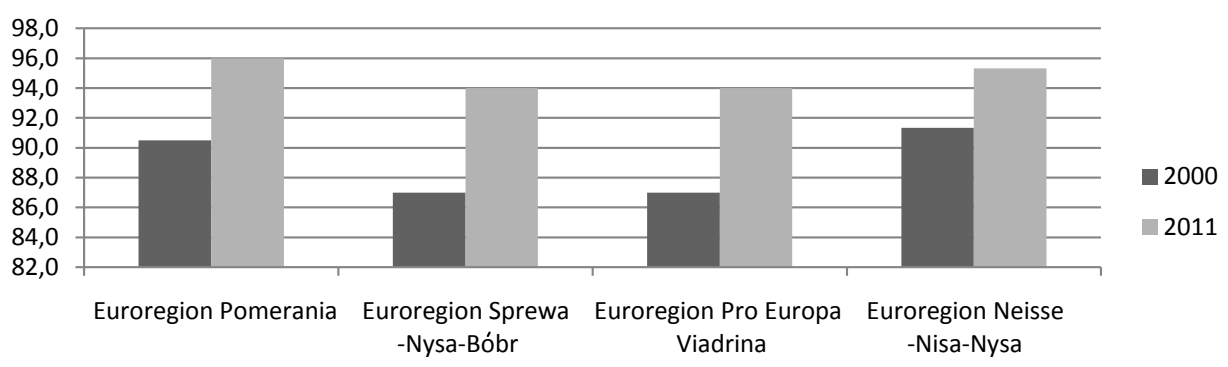

Wykres 6.1. Procent populacji euroregionów z dostępem do wody publicznej

Źródło: opracowanie własne na podstawie GUS, Euroregiony na granicach Polski oraz Eurostat.

Kolejną miarą związaną z oszczędnym zagospodarowaniem energii jest wskaźnik „stopniodzień ogrzewania” (heating degree day). Wskaźnik umożliwia śledzenie, czy gospodarowanie energią jest oszczędne. W latach 2000-2014 w każdym z euroregionów na zachodnim pograniczu Polski możemy dostrzec wzrost poziomu wskaźnika. 
Tabela 6.12. Wskaźnik HDD „stopniodzień ogrzewania” w euroregionach

\begin{tabular}{|c|c|c|c|c|}
\hline Lata & $\begin{array}{c}\text { Euroregion } \\
\text { Pomerania }\end{array}$ & $\begin{array}{c}\text { Euroregion Pro } \\
\text { Europa Viadrina }\end{array}$ & $\begin{array}{c}\text { Euroregion } \\
\text { Sprewa-Nysa-Bóbr }\end{array}$ & $\begin{array}{c}\text { Euroregion } \\
\text { Neisse-Nisa-Nysa }\end{array}$ \\
\hline 2000 & 2948,6 & 2833,0 & 2773,6 & 3054,7 \\
\hline 2004 & 3305,8 & 3239,8 & 3198,8 & 3447,1 \\
\hline 2008 & 3022,8 & 2967,9 & 2935,8 & 3155,6 \\
\hline 2012 & 3108,9 & 3088,5 & 3082,0 & 3312,7 \\
\hline 2014 & 3092,2 & 3081,6 & 3081,3 & 3303,7 \\
\hline
\end{tabular}

Źródło: opracowanie własne na podstawie danych Eurostat.

W Euroregionie Pomerania wskaźnik w badanym okresie wzrósł o 143,6, w Euroregionie Pro Europa Viadrina o 248,6, w Euroregionie Sprewa-Nysa-Bóbr o 307,7 a w Euroregionie Neisse-Nisa-Nysa o 249.

Analiza dostępnych danych związanych z ochroną środowiska naturalnego nie pozwala na dokonanie jednoznacznej oceny działań podejmowanych w euroregionach w zakresie ochrony środowiska. Pozytywnym efektem jest to, że coraz większa liczba ludności ma dostęp do wody pitnej oraz wzrasta poziom materiałów poddanych recyklingowi. Może to świadczyć o coraz większej świadomości ekologicznej wśród mieszkańców pogranicza.

\subsection{Doświadczenia euroregionów na zachodniej granicy Polski}

Euroregiony na zachodniej granicy Polski odegrały istotną rolę w integracji Polski z Unią Europejską. Dzięki bezpośrednim relacjom pomiędzy społecznościami po obu stronach granicy udało się przezwyciężyć część stereotypów oraz nawiązać pozytywne relacje sąsiedzkie. Poniżej omówione zostały wybrane doświadczenia, bariery oraz wnioski na przyszłość dla euroregionów na zachodniej granicy Polski.

\section{Euroregion Pomerania}

Pozytywne doświadczenia:

- kooperacja w Euroregionie prowadząca do generowania wartości dodanej w gospodarce, społeczeństwie i ochronie środowiska naturalnego,

- nawiązanie ścisłej współpracy pomiędzy lokalnymi instytucjami i uczelniami wyższymi,

- wymiana informacji i doświadczeń związanych z rozwojem regionalnym,

- stworzenie nowych miejsc spotkań kulturalnych, edukacyjnych, 
- wzrost rozpoznawalności Euroregionu poprzez promocję turystyki i inwestycje w infrastrukturę turystyczną,

- działania w Dolinie Dolnej Odry prowadzące do zapewnienia ochrony środowiska naturalnego w Euroregionie,

- zapewnienie usług publicznych i podjęcie wyzwań związanych ze zmianami demograficznymi.

Problemy i deficyty:

- odmienność struktur organizacyjno-prawnych w poszczególnych krajowych częściach Euroregionu,

- różnice w poziomie rozwoju społeczno-gospodarczego,

- brak wystarczających uregulowań wewnątrzkrajowych związanych z podejmowaniem przez władze lokalne działań związanych z obrotem publiczno-prawnym,

- słabe postępy we wdrażaniu wspólnych celów edukacyjnych,

- deficyty w sieci transportowej wschód-zachód,

- brak sieci doradztwa zawodowego,

- bariera językowa,

- niewielkie możliwości zaangażowania nowych podmiotów gospodarczych we współpracę partnerską w Euroregionie,

- niewystarczający poziom dostępu do usług publicznych dla ludności,

- brak wspólnej oferty turystycznej,

- niski poziom warunków życia na obszarach wiejskich,

- niewystarczające środki finansowe w stosunku do dużych potrzeb,

- odmienne uregulowania prawne oraz różnice w strukturze administracyjnej.

Wnioski i zadania na przyszłość:

- ujednolicenie struktur organizacyjno-prawnych w krajowych częściach Euroregionu,

- konieczność wprowadzenia uregulowań wewnątrzkrajowych związanych $\mathrm{z}$ podejmowaniem przez władze lokalne działań związanych $\mathrm{z}$ obrotem publiczno-prawnym,

- zwiększenie współpracy pomiędzy uczelniami wyższymi, lepsze wykorzystanie potencjału naukowego, współfinansowanie kursów językowych,

- silniejsze wsparcie dla sektora małych i średnich przedsiębiorstw, wprowadzenie programów współpracy oraz rozbudowa centrów gospodarczych,

- utworzenie sieci doradztwa zawodowego,

- usieciowienie oferty turystycznej,

- poprawa jakości życia na obszarach wiejskich,

- dalsza współpraca na rzecz zapewnienia usług publicznych dla lokalnej ludności,

- opracowanie priorytetów dalszej współpracy związanych z ochroną środowiska naturalnego. 


\section{Euroregion Pro Europa Viadrina}

Pozytywne doświadczenia: ${ }^{31}$

- nawiązanie miarodajnej i efektywnej współpracy pomiędzy administracją samorządową a przedsiębiorstwami,

- realizacja wielu polsko-niemieckich projektów, których celem jest rozwój gospodarczy, społeczny i poprawa stanu środowiska naturalnego,

- nawiązanie sąsiedzkich relacji pomiędzy społecznościami po obu stronach granicy,

- nawiązanie partnerskiej współpracy pomiędzy poszczególnymi gminami po ubu stronach granicy w kwestiach związanych z kulturą, sportem, życiem gospodarczym, społecznym,

- nawiązanie współpracy przez organizacje pozarządowe (np. OSP) czy organizacje pracodawców (np. Zachodnia Izba Przemysłowo-Handlowa w Gorzowie Wielkopolskim z Izbą Przemysłowo-Handlową we Frankfurcie nad Odrą).

Problemy i deficyty:

- niski poziom środków finansowych pozostawionych do dyspozycji władz regionalnych,

- zróżnicowanie w poziomie i strukturze gospodarki po obu stronach granicy,

- problemy związane $\mathrm{z}$ funkcjonowaniem struktury organizacyjnej w Euroregionie,

- skomplikowane procedury związane ze składaniem wniosków o dofinansowania $\mathrm{z}$ funduszy unijnych i problemy $\mathrm{z}$ ich rozpatrywaniem,

- wysokie nakłady finansowe na administrację,

- niewystarczająca komunikacja transgraniczna,

- odmienne uregulowania i przepisy prawne po obu stronach granicy.

Zadania na przyszłość:

- rozwiązanie kwestii prefinansowania projektów oraz stworzenie centrów wsparcia dla wnioskodawców składających wnioski o dofinansowanie z funduszy UE,

- poszerzenie tematyki wymiany doświadczeń w dziedzinie gospodarki, spraw społecznych, ochrony środowiska naturalnego,

- zmniejszenie nakładów na administrację oraz poprawa funkcjonowania struktur euroregionalnych,

- doradztwo dla podmiotów gospodarczych zarejestrowanych w Euroregionie,

- rozwój komunikacji transgranicznej,

- ujednolicenie uregulowań prawnych po obu stronach granicy.

31 http://old.ue.poznan.pl/att/DZIEK_EKON/j.pulkownik_z43.pdf [dostęp 10.04.2015]. 


\section{Euroregion Sprewa-Nysa-Bóbr}

Pozytywne doświadczenia:

- nawiązanie pozytywnych kontaktów pomiędzy polską a niemiecką stroną Euroregionu i ich szybki rozwój,

- wzrost wzajemnego zaufania,

- rozwój współpracy polsko-niemieckiej,

- dobrze opracowane działania związane z informacją i rozdysponowaniem środków finansowych na realizację małych projektów,

- promocja dobrych praktyk z zakresu współpracy transgranicznej,

- wymiana młodzieży, wspólne wyjazdy integracyjne oraz kursy językowe,

- koordynacja działań związanych z zapobieganiem i zwalczaniem klęsk żywiołowych,

- udzielanie pomocy merytorycznej i współpraca z organizacjami i instytucjami,

- pozytywne oceny beneficjentów dotyczące pomocy merytorycznej, transferu wiedzy i środków finansowych.

Problemy i deficyty:

- niedostateczny poziom zaangażowania $\mathrm{w}$ nawiązywanie relacji gospodarczych po stronie niemieckiej,

- skomplikowane procedury realizacji i rozliczania projektów (zbyt duża liczba instytucji pośredniczących) oraz niedostateczny poziom dofinansowania z UE,

- słaba promocja Euroregionu i działań w nim podejmowanych,

- różnice związane z funkcjonowaniem samorządów lokalnych.

Wnioski na przyszłość:

- lepsza promocja współpracy (w szczególności po stronie niemieckiej),

- konieczność zmniejszenia liczby instytucji pośredniczących przy projektach z UE,

- optymalizacja przepisów i procedur związanych z pozyskiwaniem funduszy pieniężnych oraz udzielanie pomocy przy tworzeniu budżetów projektów euroregionalnych,

- prace związane z ujednolicaniem przepisów prawnych po obu stronach granicy.

\section{Euroregion Neisse-Nisa-Nysa}

Pozytywne doświadczenia:

- wdrożenie trójstronnej Koncepcji rozwoju transportu oraz mapy inwestycji drogowych, a także nawiązanie komunikacji transgranicznej,

- wprowadzenie nowoczesnego marketingu w turystyce,

- współpraca instytucji w dziedzinie energetyki,

- współpraca naukowo-badawcza i wdrażanie innowacji w Euroregionie, 
- działania związane z poprawą jakości wody w Nysie, budowa oczyszczalni ścieków oraz podjęcie działań mających na celu ochronę lasów,

- nawiązanie przez uczelnie wyższe współpracy i utworzenie oferty wspólnego kształcenia akademickiego.

Problemy i deficyty:

- skomplikowane procedury związane z finansowaniem projektów i ich wdrażaniem, w tym za bardzo rozbudowana struktura biurokratyczna,

- zmiana zasad funkcjonowania programów w trakcie realizacji projektów,

- nieodpowiedni stan infrastruktury drogowej utrudniający współpracę transgraniczną,

- brak sieci powiązań pomiędzy instytucjami badawczymi i naukowymi a biznesem,

- strategie rozwoju gospodarczego i turystyki uwzględniające potrzeby krajowe, a nieskoncentrowane na obszarze współpracy transgranicznej,

- słaba znajomość języków obcych wśród osób odpowiedzialnych za rozwój gospodarczy, społeczny i ochronę środowiska naturalnego w Euroregionie,

- nieodpowiednie wyposażenie jednostek odpowiedzialnych za bezpieczeństwo w Euroregionie,

- odmienne zakresy odpowiedzialności związane z zarządzaniem kryzysowym w państwach,

- niski poziom współpracy w zakresie szkolnictwa podstawowego i średniego,

- zły stan zabytków związany z brakiem środków finansowych na ich renowacje.

Wnioski na przyszłość:

- ograniczenie nadmiernej biurokracji oraz zapewnienie pomocy w zakresie pozyskiwania funduszy unijnych,

- konieczność podejmowania dalszych działań sprzyjających wzrostowi spójności społeczno-gospodarczej w Euroregionie, modernizacja i budowa nowych przejść granicznych, stworzenie odpowiedniej infrastruktury informacyjno-komunikacyjnej,

- stworzenie sieci współpracy pomiędzy ośrodkami naukowo-badawczymi,

- opracowanie nowych planów rozwoju obszaru transgranicznego,

- dofinansowanie kursów językowych,

- stworzenie wspólnych planów w zakresie zarządzania kryzysowego,

- nawiązanie współpracy pomiędzy szkołami podstawowymi i średnimi,

- konieczność stworzenia planów i budżetów ochrony zabytków,

- podejmowanie dalszych działań sprzyjających integracji społeczności lokalnych. 


\subsection{Uwagi końcowe}

Potencjał rozwojowy euroregionów na zachodniej granicy Polski w analizowanym okresie wzrastał. Zauważalna jest poprawa wskaźników związanych z rozwojem gospodarczym i społecznym. Nastąpiła poprawa wskaźnika dochód na jednego mieszkańca, spadła stopa bezrobocia, wzrósł poziom świadomości ekologicznej wśród mieszkańców pogranicza. Konkludując, euroregion dzięki odpowiedniej strukturze organizacyjnej i realizowanym strategiom przyczynia się do aktywizacji terenów przygranicznych. Przejawia się to poprawą poszczególnych wskaźników gospodarczych, społecznych i wybranych ochrony środowiska naturalnego. Wydaje się zatem słuszne twierdzenie, że rozwiązywanie problemów związanych z gospodarką odpadami, ograniczeniem zanieczyszczeń czy aktywizacją gospodarczą ludności wymaga podejmowania działań w skali ich występowania, a więc we współpracy pomiędzy gminami, powiatami i województwami. 



\section{Rozdział 7}

\section{Analiza wpływu funduszy unijnych na zrównoważony rozwój euroregionów}

\subsection{Uwagi wstępne}

Celem tego rozdziału jest statystyczna ocena wpływu unijnej polityki regionalnej na zrównoważony i trwały rozwój w euroregionach. W pierwszej części omówiona została problematyka związana $\mathrm{z}$ instrumentami polityki regionalnej i ich wykorzystaniem w euroregionach. Właściwa część rozważań poświęcona została statystycznej ocenie wpływu funduszy unijnych na zrównoważony rozwój obszarów sformalizowanej współpracy transgranicznej. Wstępem dla stochastycznej weryfikacji głównej hipotezy jest wskaźnikowa ocena zrównoważonego rozwoju w euroregionach przy wykorzystaniu wskaźnika Perkala. Ocena ta została podzielona na trzy etapy: w pierwszej części wyznaczono wskaźnik Perkala i wskaźnik postępu, następnie przeprowadzono analizę korelacji i analizę wieloraką wpływu poszczególnych wskaźników cząstkowych na kształtowanie się miary Perkala oraz dokonano prognozy wskaźnika $\mathrm{z}$ wykorzystaniem metody ekstrapolacji trendu. Wyznaczony wskaźnik zrównoważonego rozwoju pozwolił na wyznaczenie linii trendu dla wpływu środków unijnych na postęp w euroregionach.

\subsection{Instrumenty finansowe Unii Europejskiej wspierające zrównoważony rozwój euroregionów zachodniego pogranicza Polski}

Euroregiony położone na zachodnim pograniczu Polski charakteryzują się niskim poziomem rozwoju (PKB per capita nie przekracza 75\% średniej dla UE-28). Jako regiony problemowe znajdują się one w centrum zainteresowania unijnej po- 
lityki regionalnej. Instrumentami wspierającymi rozwój badanych euroregionów są następujące programy: Phare CBC oraz Interreg. W przypadku Phare środki finansowe wspierały rozwój obszarów przygranicznych graniczących z Unią Europejską ${ }^{1}$ i obejmowały: restrukturyzację i modernizację przemysłu, rolnictwa, sektora bankowego, infrastrukturę i ochronę środowiska naturalnego ${ }^{2}$. Z punktu widzenia rozwoju terenów przygranicznych przy zachodniej granicy Rzeczpospolitej podstawowe znaczenie miał wydzielony z Programu Phare Program Współpracy Przygranicznej (Phare CBC - 25\% środków w ramach Phare). Środki z funduszy przekazywane były w pierwszym okresie na rozwój czterech euroregionów na granicy polsko-niemieckiej. Pozytywne efekty współpracy przyczyniły się do zwiększenia obszaru wsparcia na całość granic Rzeczpospolitej Polskiej.

Największą inicjatywą Unii Europejskiej wspierającą rozwój regionów przygranicznych jest Interreg. Zrealizowane inicjatywy objęły następujące programy i okresy programowania: Interreg I na lata 1991-1993, Interreg II w latach 1994 -1999, Interreg III w latach 2000-2006, Interreg IV na lata 2007-2013. Polska stała się beneficjentem programu Interreg wraz z przystąpieniem do Unii Europejskiej. W pierwszym okresie programowania Rzeczpospolita Polska uzyskała 221,4 mln euro, w tym na: Komponent A - współpraca transgraniczna (177,09 mln - 80\%), Komponent B - współpraca transnarodowa (30,99 mln - 14\%), Komponent C współpraca międzyregionalna (13,28 $\mathrm{mln}-6 \%)$.

W ramach komponentu współpraca transgraniczna na terenie Polski realizowanych jest siedem programów, w tym pięć dwustronnych: Meklemburgia -Pomorze Przednie (Euroregion Pomerania), Polska-Brandenburgia (Euroregion Pro Europa Viadrina otrzyma 43,5\% środków na FMP, a Euroregion Sprewa -Nysa-Bóbr 56,5\%), Polska-Saksonia i Polska-Czechy (Euroregion Neisse-Nisa -Nysa), Polska-Słowacja oraz dwa trójstronne: Polska-Litwa-Federacja Rosyjska, Polska-Białoruś-Ukraina.

Zasadniczą część środków w ramach funduszy unijnych przeznaczono na następujące obszary tematyczne: transport (51\%), ochronę zasobów przyrody $(26 \%)$, rozwój gospodarczy $(2,3 \%)$, zasoby ludzkie $(7,4 \%)$, infrastrukturę komunalną $(3,8 \%)^{3}$.

Z Funduszu Małych Projektów Programu Phare CBC w latach 1995-2003 największe dofinansowanie uzyskał Euroregion Pomerania (5,8 mln euro), najmniejsze Euroregion Sprewa-Nysa-Bóbr (3,9 mln euro). W ramach inicjatywy Interreg w latach 2001-2006 budżet programu operacyjnego Meklemburgia-Pomorze Przednie wyniósł 251 mln euro, Programu Polska-Saksonia 176,9 mln euro, a Polska-Brandenburgia 256,7 mln euro.

$1 \quad$ P. Churski, Programy wspólnotowe i ich struktura w systemie środków pomocowych dla Polski, Wyższa Szkoła Humanistyczno-Ekonomiczna we Włocławku, http://www.staff.amu.edu. pl/ chur/bibliografia/PROGRAMY\%20WSPOLNOTOWE.pdf, s. 4 [dostęp 12.07.2012].

3 http://euroregion-snb.pl/program/phare [dostęp 15.09.2014]. 
Tabela 7.1. Alokacja funduszy unijnych w euroregionach zachodniego pogranicza Polski (euro)

\begin{tabular}{|c|c|c|c|c|c|}
\hline Instrument & Lata & $\begin{array}{c}\text { Euroregion } \\
\text { Pomerania }\end{array}$ & $\begin{array}{c}\text { Euroregion } \\
\text { Pro Europa } \\
\text { Viadrina }\end{array}$ & $\begin{array}{c}\text { Euroregion } \\
\text { Sprewa } \\
\text {-Nysa-Bóbr }\end{array}$ & $\begin{array}{c}\text { Euroregion } \\
\text { Neisse } \\
\text {-Nisa-Nysa }\end{array}$ \\
\hline $\begin{array}{c}\text { Funduszu Małych } \\
\text { Projektów Programu } \\
\text { Phare CBC }\end{array}$ & $1995-2003$ & $5,8 \mathrm{mln}$ & $4,2 \mathrm{mln}$ & $3,9 \mathrm{mln}$ & $5 \mathrm{mln}$ \\
\hline Interreg & $2001-2006$ & $118,2 \mathrm{mln}$ & \multicolumn{2}{|c|}{$132,2 \mathrm{mln}$} & $71,9 \mathrm{mln}$ \\
\cline { 2 - 6 } & $2007-2013$ & $132,8 \mathrm{mln}$ & \multicolumn{2}{|c|}{$124,5 \mathrm{mln}$} & $105 \mathrm{mln}$ \\
\hline
\end{tabular}

Źródło: opracowanie własne na podstawie danych z Sekretariatów Euroregionów.

W latach 2001-2013 w Euroregionie Pomerania średniorocznie realizowano 125 projektów, a przeciętna roczna kwota dofinansowania wszystkich projektów wyniosła 1,2 mln euro, w Euroregionie Pro Europa Viadrina - 129 projektów, a średnia kwota dofinansowania wyniosła 0,8 mln euro, w Euroregionie Sprewa -Nysa-Bóbr - 186 projektów, a średnia kwota dofinansowania wyniosła 2,9 mln euro, w Euroregionie Neisse-Nisa-Nysa - 102 projekty, a średnia kwota dofinansowania wyniosła 1,1 mln euro.

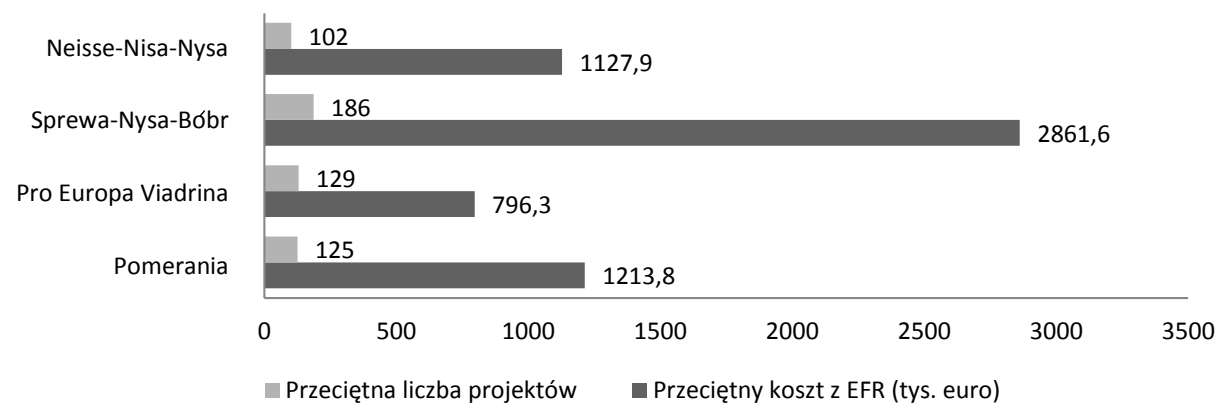

Wykres 7.1. Przeciętne roczne kwoty dofinansowania z Funduszu Małych Projektów oraz przeciętna roczna liczba zrealizowanych projektów w latach 2001-2013

Źródło: obliczenia własne na podstawie danych z Sekretariatów Euroregionów.

\subsection{Statystyczna ocena wpływu unijnych funduszy regionalnych na zrównoważony rozwój euroregionów}

Zrównoważony rozwój badanych euroregionów uwarunkowany jest przez szereg czynników o charakterze egzogenicznym i endogenicznym. Niewątpliwie jednak sąsiedztwo z Niemcami oraz transfery środków w ramach polityki regio- 
nalnej UE powodują, że rozwój ten nabiera większego tempa i pozwala zmniejszać negatywne aspekty przygranicznego położenia. Instrumenty finansowe unijnej polityki regionalnej istotnie przyczyniają się do poprawy jakości i warunków życia lokalnych społeczności. Świadectwem dla takiego stwierdzenia są materialne i niematerialne projekty zrealizowane w euroregionach ze środków unijnych, które nie doszłyby do skutku bez zaangażowania funduszy europejskich. Statystyczne badanie mające na celu zweryfikowanie głównej hipotezy badawczej przeprowadzono w dwóch etapach:

1. Wyznaczono syntetyczny wskaźnik zrównoważonego rozwoju euroregionów zachodniego pogranicza Polski oraz określono funkcję dominującą regionu z wykorzystaniem wskaźnika specjalizacji Florence’a (zmierzono stopień korelacji pomiędzy rozwojem ekonomicznym, społecznym i środowiskowym w każdym euroregionie oraz określono stopień statystycznej zależności pomiędzy rozwojem poszczególnych euroregionów),

2. Stworzono model empiryczno-indukcyjny pozwalający na ocenę wpływu funduszy polityki regionalnej Unii Europejskiej na zrównoważony rozwój euroregionów zachodniego pogranicza Polski.

\subsubsection{Metodyka badań}

W literaturze przedmiotu występuje pewien niedosyt jeżeli chodzi o badanie wpływu funduszy regionalnych UE na zrównoważony rozwój euroregionów. Istnieje natomiast szereg badań i pomiarów dotyczących rozwoju regionalnego ${ }^{4}$.

Podjęta problematyka niesie za sobą konieczność określenia zależności przyczynowo-skutkowej pomiędzy środkami z funduszy unijnej polityki regionalnej a zrównoważonym rozwojem zachodniego pogranicza Polski. Związek pomiędzy dwoma zmiennymi zmierzono z wykorzystaniem wskaźnika korelacji Pearsona, natomiast analizę przyczynowo-skutkową przeprowadzono $\mathrm{z}$ wykorzystaniem metod stochastycznych z jedną zmienną objaśniającą.

Analiza rozwoju euroregionów zbudowana została w oparciu o syntetyczny wskaźnik Perkala, który charakteryzuje się przejrzystością oraz nieznacznym ubytkiem informacji podczas agregacji ${ }^{5}$. Wskaźnik Perkala jest sumą standaryzowanych wskaźników cząstkowych, których dobór wynika z literatury przedmiotu. Kryteria, które brane były pod uwagę w wyborze wskaźników to: bezpośrednia mierzalność i porównywalność danych oraz ich dostępność dla całego badanego okresu.

4 G. Karmowska, Badanie i pomiar rozwoju regionalnego na przykładzie województwa zachodniopomorskiego, „Roczniki Nauk Rolniczych. Seria G", nr 2/2011, t. 98.

5 Z. Chojnicki, T. Czyż, Zróżnicowanie przestrzenne poziomu życia ludności,„Biuletyn KPZK PAN”, nr 153/1991, s. 153. 
Syntetyczny wskaźnik zrównoważonego rozwoju euroregionów $\left(W_{r}\right)$ obliczono zgodnie z metodą sum standaryzowanych, przy założeniu, że zrównoważony rozwój euroregionów jest równy sumie wskaźników cząstkowych: wskaźnika rozwoju ekonomicznego $\left(W_{e}\right)$, wskaźnika rozwoju społecznego $\left(W_{s p}\right)$ oraz wskaźnika środowiskowego $\left(W_{s r}\right)$. Formalnie można to zapisać wzorem:

$$
W_{r}=W_{e}+W_{s p}+W_{s} r
$$

Wstępna analiza zmiennych przeprowadzona została pod kątem stopnia skorelowania, aby wyeliminować te, które zawierają informacje powtarzające się. Jako wartość progową przyjęto współczynnik korelacji $\mathrm{r}=|0,75|$.

Tworząc wskaźnik rozwoju ekonomicznego $\left(W_{e}\right)$, użyto wskaźników:

$x_{1}-\mathrm{PKB}$ per capita w euroregionach,

Tworząc wskaźnik rozwoju społecznego $\left(W_{s p}\right)$, użyto wskaźników:

$x_{2}$ - procentowy udział osób zatrudnionych $\mathrm{w}$ ogólnej liczbie ludności w wieku produkcyjnym,

$x_{3}$ - procentowy udział osób posiadających wykształcenie co najmniej średnie w ogólnej liczbie ludności pomiędzy 18-64 rokiem życia,

$x_{4}$ - liczbę personelu medycznego w euroregionach,

Tworząc wskaźnik ochrony środowiska $\left(W_{s r}\right)$, użyto wskaźników:

$x_{5}$ - wskaźnik generowania odpadów komunalnych,

$x_{6}$ - wskaźnik heating degree days.

Wybrane wskaźniki mają różne jednostki i wagi stąd też konieczność dokonania standaryzacji zmiennych tak, aby wyeliminować jednostki miary i wyrównać wartości zmiennych. Standaryzację zmiennych obliczono zgodnie ze wzorem:

$$
W P_{n \times k}=\frac{X_{n k}-\overline{X_{k}}}{S k}
$$

gdzie: $\overline{X_{k}}=\frac{1}{w} \sum_{i=1}^{w} X_{n k}$

$$
S k=\sqrt{\frac{\sum_{i=1}^{W}\left(X_{n k}-\overline{X_{k}}\right)^{2}}{w}}
$$

gdzie:

$k=1,2,3, \ldots, n$

$X_{k}$ - średnia arytmetyczna $k$-tej zmiennej,

$S k$ - odchylenie standardowe $k$-tej zmiennej,

$W P_{n \times k}$ - standaryzowana wartość $k$-tej zmiennej w $i$-tej jednostce,

$w$ - liczba obserwacji. 
Wystandaryzowany wskaźnik zrównoważonego rozwoju euroregionów obliczony został dla piętnastu obserwacji rocznych od 2000 do 2014 r. Wśród wskaźników wykorzystanych do stworzenia syntetycznego wskaźnika zrównoważonego rozwoju można wyróżnić stymulanty i destymulanty, co spowodowało konieczność zamiany destymulant na stymulanty. W niniejszej mnografii dokonano tego, zmieniając znaki plus na minus i odwrotnie przed wartościami destymulant, a następnie stworzono syntetyczne wskaźniki Perkala, będące sumą standaryzowanych wartości cząstkowych w oparciu o wzór:

$$
W P=\frac{1}{n} \sum_{j=1}^{n} y_{i j}
$$

gdzie:

WP - wskaźnik Perkala,

$y_{i j}$ - standaryzowana wartość $j$-tej cechy w $i$-tym obiekcie,

$n$ - liczba badanych cech.

Następnie wyznaczono wskaźnik postępu jako różnicę pomiędzy wartościami wyznaczonych wskaźników Perkala dla analizowanych euroregionów pomiędzy okresem końcowym (2014 r.) a okresem bazowym (2000 r.) w opraciu o wzór:

$$
W_{\text {postępu }}=W P_{2014}-W P_{2000}
$$

Kolejny etap analizy zrównoważonego rozwoju euroregionów poświęcony został badaniu wpływu zmiennych cząstkowych określonych jako zmienna rozwoju ekonomicznego, społecznego i środowiskowego na kształtowanie się zrównoważonego rozwoju. W celu sprawdzenia poziomu zależności liniowej pomiędzy analizowanymi miernikami posłużono się wskaźnikiem korelacji Pearsona. Estymator współczynnika korelacji liniowej obliczono zgodnie ze wzorem:

$$
\begin{gathered}
r_{x y}=\frac{\sum_{1=1}^{n}\left(x_{i}-x_{s} r\right)\left(y_{i}-y_{s r}\right)}{\sqrt{\sum_{i=1}^{n}\left(x_{i}-x_{s r}\right)^{2}} \sqrt{\sum_{i=1}^{n}\left(y_{i}-y_{s r}\right)^{2}}} \\
r_{x y} \in[-1 ; 1]
\end{gathered}
$$

gdzie:

$r_{x y}$ - współczynnik korelacji Pearsona,

$x_{s r}, y_{s r}-$ średnie wartości zmiennych,

$x, y$-zmienne poddane analizie.

Współczynnik pozwolił na dokonanie oceny siły korelacji pomiędzy analizowanymi zmiennymi. W prowadzonej analizie przyjęto następujące siły związku korelacyjnego: 
- $|r|=0$ brak korelacji,

- $(0 ;|r| ; 0,4\rangle$ słaba korelacja,

- $(0,4 ;|r| ; 0,7\rangle$ średnia korelacja,

- $(0,7 ;|r| ; 0,9\rangle$ silna korelacja,

- $(0,9 ;|r| ; 1\rangle$ bardzo silna.

Analiza korelacji stosowana jest do oceny stopnia powiązania pomiędzy zmiennymi, natomiast jej uzupełnienie, jeżeli chodzi o metody oceny stopnia współzależności pomiędzy zmiennymi, stanowi analiza regresji. Pozwala ona na dokonanie ilościowego opisu zachodzących powiązań pomiędzy zmiennymi.

W celu sprawdzenia zależności funkcyjnej pomiędzy wskaźnikami zrównoważonego rozwoju przeprowadzono estymację przy pomocy Klasycznej Metody Najmniejszych Kwadratów (KMNK), której idea polega na wyznaczeniu takich estymatorów $a_{1}, a_{2}, \ldots, a_{K}$, przy których suma kwadratów reszt byłaby najmniejsza.

Równanie regresji wyznaczono zgodnie ze wzorem $^{6}$ :

$$
V=\sum_{j=1}^{n}\left(y_{j}-y_{S z j}\right)^{2}=\sum_{j=1}^{n} z_{j}^{2}=\min \rightarrow 0
$$

Kolejny etap badania polegał na próbie oszacowania prognozowanych wartości wskaźnika Perkala w euroregionach w latach 2015-2020. Prognoza sporządzona została w oparciu o metodę ekstrapolacji trendu. Wybór tej metody związany jest z tym, że postać analityczna funkcji trendu dla wskaźnika Perkala i wartość jej parametrów strukturalnych w okresie $t$, dla którego dokonano prognozy, nie powinny ulec istotnej zmianie $\mathrm{w}$ porównaniu $\mathrm{z}$ okresami wcześniejszymi, które posłużyły za podstawę do oszacowania funkcji trendu. Przy wykorzystaniu metody ekstrapolacji trendu stworzono model addytywny wahań w czasie zgodnie $\mathrm{z}$ następującym wzorem:

$$
Y_{t}=F(t)+G_{i}(t)+\xi_{t}
$$

natomiast jego oszacowanie:

$$
Y_{t}=f(t)+g_{i t}+z_{t}
$$

gdzie:

$Y_{t}$ - poziom badanego zjawiska,

$F(t)$ - funkcja tendencji rozwojowej lub stały poziom zjawiska w populacji generalnej,

6 N. Łapińska-Sobczak, Opisowe modele ekonometryczne. Elementy teorii. Przykłady i zadania, Wydawnictwo Uniwersytetu Łódzkiego, Łódź 2001, s. 42. 
$G_{i}(t)$ - funkcja wahań okresowych, przy czym $i=1,2, \ldots, d$ oznacza liczbę podokresów w cyklu okresowości,

$f(t)$ - funkcja trendu (czasu),

$g_{\text {it }}$ - oszacowanie wahań addytywnych - absolutne poziomy wahań,

$\xi_{t}$ - składnik losowy modelu wahań w czasie.

Funkcję dominującą euroregionów wyznaczono z wykorzystaniem wskaźnika specjalizacji Florence’a:

$$
W_{s i}=\frac{Z_{i r}}{Z_{r}} \div \frac{Z_{i k}}{Z_{k}}
$$

gdzie $^{7}$ :

$W_{s i}$ - współczynnik specjalizacji pracujących $\mathrm{w} i$-tej funkcji euroregionu,

$Z_{i r}$ - liczba pracujących $\mathrm{w} i$-tym dziale gospodarki w regionie,

$Z_{i K}$ - liczba pracujących $\mathrm{w} i$-tym dziale gospodarki w kraju,

$Z_{r}$ - ogólna liczba pracujących w regionie,

$Z_{k}$ - ogólna liczba pracujących w kraju.

Wskaźnik pozwolił na wyodrębnienie i ocenę poziomu specjalizacji euroregionów. Wartości wskaźnika wyższe od jedności wskazały na egzogeniczny charakter prowadzonej w euroregionach działalności.

Końcowy fragment badania pozwolił na zweryfikowanie postawionej we wstępie monografii hipotezy badawczej. W pierwszej kolejności dokonano pomiaru poziomu wykorzystania Funduszu Małych Projektów za pomocą wskaźnika absorbcji. Informacje na temat pozyskiwania funduszy Unii Europejskiej przez euroregiony na zachodnim pograniczu Polski w perspektywie 2009-2014 zaczerpnięte zostały ze stron internetowych euroregionów. Obliczono wskaźnik wykorzystania Funduszu Małych Projektów UE w euroregionach zgodnie ze wzorem:

$$
W_{A}=0,6 * W_{p}+0,4 * L_{P}
$$

gdzie:

$W_{A}$ - wskaźnik absorbcji z FMP,

$W_{p}-$ kwota dofinansowania na 1 tys. mieszkańców,

$L_{p}-$ liczba projektów na mieszkańca.

7 G. Karmowska, Badanie i pomiar rozwoju regionalnego na przykładzie województwa zachodniopomorskiego, „Roczniki Nauk Rolniczych. Seria G”, nr 2/2011, t. 98, s. 87. 
Następnie stworzono funkcję zależności pomiędzy różnicą wskaźnika Perkala w euroregionach w latach 2000-2014 (wskaźnika postępu) a wartością środków finansowych przekazanych $w$ ramach funduszy unijnych na rzecz współpracy transgranicznej oraz przeprowadzono analizę korelacji i regresji pomiędzy analizowanymi zmiennymi.

\subsubsection{Wyniki badań}

Analiza wskaźnika zrównoważonego rozwoju w euroregionach przeprowadzona dla lat 2000-2014 pozwala dostrzec, że w każdym z euroregionów nastąpił jego wzrost (tabela 7.2). W 2000 r. trzy euroregiony (Pomerania, Sprewa-Nysa-Bóbr oraz Neisse-Nisa-Nysa) objęte badaniem wykazały ujemne wartości standaryzowanego wskaźnika rozwoju zrównoważonego, natomiast w 2014 r. wszystkie miary były dodatnie. Najszybciej rozwijającymi się euroregionami są Euroregiony Neisse -Nisa-Nysa, gdzie standaryzowany wskaźnik rozwoju (We) w 2000 r. wyniósł -4,76, a w 2014 r. 8,26 oraz Euroregion Pomerania, gdzie wzrósł z poziomu -6,87 do poziomu 6,3. Niższy poziom rozwoju prezentują Euroregion Pro Europa Viadrina, gdzie wskaźnik ten wyniósł w 2000 r. 0,52, a w 2014 - 2,95 oraz Euroregion Sprewa-Nysa -Bóbr, gdzie wskaźnik przyjął odpowiednio wartości -3,47 oraz 5,28.

Tabela 7.2. Wystandaryzowane wskaźniki rozwoju dla euroregionów oraz wskaźnik Perkala (WP) na zachodnim pograniczu Polski

\begin{tabular}{|c|c|c|c|c|c|c|c|c|c|c|}
\hline \multirow{3}{*}{ Lata } & \multicolumn{5}{|c|}{ Pomerania } & \multicolumn{5}{|c|}{ Pro Europa Viadrina } \\
\hline & \multicolumn{4}{|c|}{$\begin{array}{c}\text { Standaryzowane wskaźniki } \\
\text { rozwoju }\end{array}$} & \multirow[t]{2}{*}{$W P$} & \multicolumn{4}{|c|}{$\begin{array}{c}\text { Standaryzowane wskaźniki } \\
\text { rozwoju }\end{array}$} & \multirow[t]{2}{*}{$W P$} \\
\hline & $W_{e}$ & $W_{s}$ & $W_{s r}$ & $W_{r}$ & & $W_{e}$ & $W_{s}$ & $W_{i r}$ & $W_{r}$ & \\
\hline 2000 & $-1,11$ & $-4,35$ & $-1,41$ & $-6,87$ & $-1,15$ & $-1,37$ & 0,79 & 1,11 & 0,52 & 0,09 \\
\hline 2001 & $-1,23$ & $-1,44$ & $-1,61$ & $-4,28$ & $-0,71$ & $-1,12$ & $-1,47$ & 0,02 & $-2,57$ & $-0,43$ \\
\hline 2002 & $-1,04$ & $-0,77$ & $-0,13$ & $-1,94$ & $-0,32$ & $-1,11$ & $-0,89$ & 1,42 & $-0,58$ & $-0,10$ \\
\hline 2003 & $-0,99$ & $-0,19$ & $-0,26$ & $-1,44$ & $-0,24$ & $-1,22$ & $-1,13$ & 0,97 & $-1,38$ & $-0,23$ \\
\hline 2004 & $-0,77$ & $-0,82$ & $-0,25$ & $-1,84$ & $-0,31$ & $-0,99$ & $-2,49$ & $-0,97$ & $-4,46$ & $-0,74$ \\
\hline 2005 & $-0,52$ & $-0,18$ & 0,05 & $-0,65$ & $-0,11$ & $-0,65$ & $-2,43$ & $-1,26$ & $-4,34$ & $-0,72$ \\
\hline 2006 & $-0,14$ & $-0,58$ & 0,73 & 0,01 & 0,00 & $-0,31$ & $-0,57$ & $-0,57$ & $-1,46$ & $-0,24$ \\
\hline 2007 & 0,47 & 0,59 & 2,02 & 3,08 & 0,51 & 0,15 & 0,65 & 0,74 & 1,54 & 0,26 \\
\hline 2008 & 0,48 & 1,68 & 1,66 & 3,82 & 0,64 & 0,64 & 1,51 & 0,33 & 2,49 & 0,42 \\
\hline 2009 & $-0,34$ & 1,71 & $-0,52$ & 0,85 & 0,14 & 0,18 & 1,63 & $-1,38$ & 0,44 & 0,07 \\
\hline 2010 & 0,58 & 2,05 & $-0,53$ & 2,10 & 0,35 & 0,71 & 2,08 & $-0,41$ & 2,38 & 0,40 \\
\hline 2011 & 1,06 & 2,30 & $-0,53$ & 2,83 & 0,47 & 1,01 & 2,34 & $-0,90$ & 2,46 & 0,41 \\
\hline 2012 & 0,99 & 3,07 & 0,68 & 4,74 & 0,79 & 1,13 & 2,07 & $-1,05$ & 2,16 & 0,36 \\
\hline 2013 & 1,19 & 3,54 & 0,79 & 5,52 & 0,92 & 1,36 & 2,39 & $-1,19$ & 2,56 & 0,43 \\
\hline 2014 & 1,38 & 4,02 & 0,91 & 6,30 & 1,05 & 1,59 & 2,71 & $-1,34$ & 2,95 & 0,49 \\
\hline
\end{tabular}


Tabela 7.2. (cd.)

\begin{tabular}{|c|c|c|c|c|c|c|c|c|c|c|}
\hline \multirow{3}{*}{ Lata } & \multicolumn{5}{|c|}{ Sprewa-Nysa-Bóbr } & \multicolumn{5}{|c|}{ Neisse-Nisa-Nysa } \\
\hline & \multicolumn{4}{|c|}{$\begin{array}{c}\text { Standaryzowane wskaźniki } \\
\text { rozwoju }\end{array}$} & \multirow{2}{*}{$W P$} & \multicolumn{4}{|c|}{$\begin{array}{c}\text { Standaryzowane wskaźniki } \\
\text { rozwoju }\end{array}$} & \multirow{2}{*}{$W P$} \\
\hline & $W_{e}$ & $W_{s}$ & $W_{s i}$ & $W_{\dot{r}}$ & & $W_{e}$ & $W_{s}$ & $W_{s r^{\circ}}$ & $W_{\dot{r}}$ & \\
\hline 2000 & $-1,12$ & $-5,12$ & 2,77 & $-3,47$ & $-0,58$ & $-1,47$ & $-2,54$ & $-0,75$ & $-4,76$ & $-0,79$ \\
\hline 2001 & $-0,82$ & $-1,88$ & 0,00 & $-2,70$ & $-0,45$ & $-1,15$ & $-2,33$ & $-1,83$ & $-5,31$ & $-0,89$ \\
\hline 2002 & $-0,80$ & $-0,91$ & 1,20 & $-0,51$ & $-0,09$ & $-0,90$ & $-1,67$ & 0,07 & $-2,50$ & $-0,42$ \\
\hline 2003 & $-0,90$ & $-0,31$ & 0,85 & $-0,36$ & $-0,06$ & $-0,95$ & $-1,10$ & $-0,88$ & $-2,93$ & $-0,49$ \\
\hline 2004 & $-0,62$ & $-1,04$ & $-0,58$ & $-2,23$ & $-0,37$ & $-0,69$ & $-0,73$ & $-0,51$ & $-1,93$ & $-0,32$ \\
\hline 2005 & $-0,20$ & $-1,62$ & $-1,83$ & $-3,65$ & $-0,61$ & $-0,31$ & $-0,20$ & $-1,73$ & $-2,24$ & $-0,37$ \\
\hline 2006 & 0,19 & $-0,37$ & $-1,09$ & $-1,27$ & $-0,21$ & 0,16 & 0,36 & $-0,88$ & $-0,36$ & $-0,06$ \\
\hline 2007 & 0,72 & 1,30 & 0,78 & 2,80 & 0,47 & 0,66 & 1,94 & 2,03 & 4,63 & 0,77 \\
\hline 2008 & 1,3 & 2,71 & 0,17 & 4,18 & 0,70 & 1,18 & 2,87 & 2,16 & 6,21 & 1,04 \\
\hline 2009 & 0,82 & 2,13 & $-1,50$ & 1,45 & 0,24 & 0,72 & 1,76 & 0,87 & 3,35 & 0,56 \\
\hline 2010 & 1,43 & 2,53 & $-0,77$ & 3,18 & 0,53 & 1,21 & 1,54 & 1,44 & 4,19 & 0,70 \\
\hline 2011 & 1,80 & 2,59 & $-1,50$ & 2,89 & 0,48 & 1,54 & 0,09 & 1,00 & 2,63 & 0,44 \\
\hline 2012 & 1,95 & 3,85 & $-1,75$ & 4,04 & 0,67 & 1,84 & 2,64 & 1,85 & 6,33 & 1,06 \\
\hline 2013 & 2,22 & 4,44 & $-20,00$ & 4,66 & 0,78 & 2,12 & 3,05 & 2,13 & 7,30 & 1,22 \\
\hline 2014 & 2,05 & 5,03 & $-2,25$ & 5,28 & 0,88 & 2,41 & 3,45 & 2,40 & 8,26 & 1,38 \\
\hline
\end{tabular}

Źródło: obliczenia własne.

Wyznaczony wskaźnik Perkala pozwala ocenić, że wszystkie analizowane euroregiony znajdują się na stosunkowo niskim poziomie zrównoważonego rozwoju, przy czym decydujący wpływ na ten stan rzeczy mają wskaźniki określające stan ochrony środowiska naturalnego. W euroregionach zachodniego pogranicza Polski na przestrzeni lat 2000-2014 miała miejsce poprawa wskaźnika Perkala. Najwyższy jego poziom w 2014 r. miał miejsce w Euroregionie Neisse-Nisa-Nysa $(1,38)$ oraz w Euroregionie Pomerania $(1,05)$. Niski poziom rozwoju odnotowano zaś w Euroregionie Pro Europa Viadrina $(0,49)$ oraz w Euroregionie Sprewa -Nysa-Bóbr $(0,88)$.

Przeprowadzona wstępna analiza wskaźnika zrównoważonego rozwoju pozwala ocenić, że otrzymane rezultaty są zgodne z faktycznym stanem rzeczy i w dużej mierze wynikają z peryferyjnego położenia wzdłuż granic państwowych. Należy jednocześnie zauważyć, że o niskim poziomie zrównoważonego rozwoju w znacznej mierze decyduje dużo niższy poziom rozwoju polskich i czeskich części euroregionów w porównaniu z częściami niemieckimi (przy czym należy odnotować, że niemiecki obszar transgraniczny przy granicy z Polską jest jednym z najbardziej opóźnionych pod względem gospodarczym, społecznym i środowiskowym terenów Niemiec). 


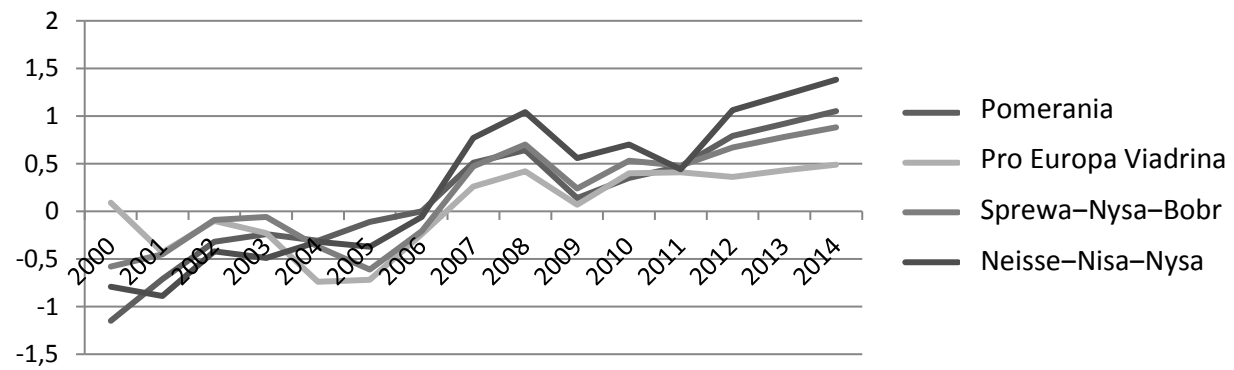

Wykres 7.2. Wskaźniki Perkala w euroregionach zachodniego pogranicza Polski w latach 2000-2014

Źródło: opracowanie własne.

Wybrane statystyki opisowe dla analizy wskaźników zrównoważonego rozwoju zaprezentowano w tabeli 7.3. Maksymalna wartość wskaźnika Perkala w Euroregionie Pomerania wynosi 1,05, minimalna wartość $-1,14$, odchylenie standardowe 0,62 , wariancja (będąca średnią arytmetyczną kwadratów odchyleń poszczególnych wartości cechy od wartości oczekiwanej) wynosi 0,39, mediana (wartość środkowa zbioru danych) 0,14 , średnia wartość wskaźnika 0,14 , natomiast kurtoza (wskazuje, na ile obserwacje są skoncentrowane wokół średniej) -0,34.

Tabela 7.3. Wybrane statystyki opisowe dla wskaźników zrównoważonego rozwoju

\begin{tabular}{|c|c|c|c|c|c|c|c|c|}
\hline & \multicolumn{4}{|c|}{ Pomerania } & \multicolumn{4}{c|}{ Pro Europa Viadrina } \\
\cline { 2 - 10 } Statystyka & $\begin{array}{c}\text { Wskaź- } \\
\text { nik } \\
\text { ekono- } \\
\text { miczny }\end{array}$ & $\begin{array}{c}\text { Wskaź- } \\
\text { nik spo- } \\
\text { łeczny }\end{array}$ & $\begin{array}{c}\text { Wskaź- } \\
\text { nik śro- } \\
\text { dowi- } \\
\text { skowy }\end{array}$ & $W P$ & $\begin{array}{c}\text { Wskaź- } \\
\text { nik } \\
\text { ekono- } \\
\text { miczny }\end{array}$ & $\begin{array}{c}\text { Wskaź- } \\
\text { nik spo- } \\
\text { łeczny }\end{array}$ & $\begin{array}{c}\text { Wskaź- } \\
\text { nik śro- } \\
\text { dowi- } \\
\text { skowy }\end{array}$ & $W P$ \\
\hline Średnia & 0,00 & 0,71 & 0,11 & 0,14 & 0,00 & 0,48 & $-0,30$ & 0,03 \\
\hline Mediana & $-0,14$ & 0,59 & $-0,13$ & 0,14 & 0,15 & 0,79 & $-0,57$ & 0,09 \\
\hline Minimum & $-1,23$ & $-4,35$ & $-1,61$ & $-1,14$ & $-1,37$ & $-2,49$ & $-1,38$ & $-0,74$ \\
\hline Maksimum & 1,38 & 4,02 & 2,02 & 1,05 & 1,59 & 2,71 & 1,42 & 0,49 \\
\hline $\begin{array}{c}\text { Odchylenie } \\
\text { standardo- } \\
\text { we }\end{array}$ & 0,93 & 2,22 & 1,02 & 0,62 & 1,03 & 1,82 & 0,98 & 0,42 \\
\hline Wariancja & 0,86 & 4,92 & 1,05 & 0,39 & 1,07 & 3,31 & 0,97 & 0,18 \\
\hline Rozstęp & 2,61 & 8,37 & 3,63 & 2,20 & 2,96 & 5,20 & 2,80 & 1,23 \\
\hline Kwartyl & 1,98 & 3,07 & 1,32 & 0,94 & 2,12 & 3,21 & 1,93 & 0,65 \\
\hline Skośność & 0,09 & $-0,52$ & 0,20 & $-0,42$ & 0,09 & $-0,42$ & 0,55 & $-0,71$ \\
\hline Kurtoza & $-1,61$ & 0,40 & $-0,31$ & $-0,34$ & $-1,58$ & $-1,35$ & $-1,28$ & $-0,75$ \\
\hline
\end{tabular}


Tabela 7.3. (cd.)

\begin{tabular}{|c|c|c|c|c|c|c|c|c|}
\hline & \multicolumn{4}{|c|}{ Sprewa-Nysa-Bóbr } & \multicolumn{4}{c|}{ Neisse-Nisa-Nysa } \\
\cline { 2 - 10 } Statystyka & $\begin{array}{c}\text { Wskaź- } \\
\text { nik } \\
\text { ekono- } \\
\text { miczny }\end{array}$ & $\begin{array}{c}\text { Wskaź- } \\
\text { nik spo- } \\
\text { teczny }\end{array}$ & $\begin{array}{l}\text { Wskaźnik } \\
\text { środowi- } \\
\text { skowy }\end{array}$ & WP & $\begin{array}{c}\text { Wskaź- } \\
\text { nik } \\
\text { ekono- } \\
\text { miczny }\end{array}$ & $\begin{array}{c}\text { Wskaź- } \\
\text { nik spo- } \\
\text { teczny }\end{array}$ & $\begin{array}{c}\text { Wskaźnik } \\
\text { środowi- } \\
\text { skowy }\end{array}$ & $W P$ \\
\hline Średnia & 0,56 & 0,89 & $-0,50$ & 0,16 & 0,42 & 0,61 & 0,49 & 0,26 \\
\hline Mediana & 0,72 & 1,30 & $-0,77$ & 0,24 & 0,66 & 0,36 & 0,87 & 0,44 \\
\hline Minimum & $-1,12$ & $-5,12$ & $-2,25$ & $-0,61$ & $-1,47$ & $-2,54$ & $-1,83$ & $-0,89$ \\
\hline Maksimum & 2,50 & 5,03 & 2,77 & 0,88 & 2,41 & 3,45 & 2,40 & 1,38 \\
\hline $\begin{array}{c}\text { Odchylenie } \\
\text { standardo- } \\
\text { we }\end{array}$ & 1,26 & 2,79 & 1,43 & 0,52 & 1,28 & 2,01 & 1,50 & 0,77 \\
\hline Wariancja & 1,59 & 7,80 & 2,06 & 0,27 & 1,64 & 4,05 & 2,25 & 0,59 \\
\hline Rozstęp & 3,62 & 10,15 & 5,02 & 1,49 & 3,88 & 5,99 & 4,23 & 2,27 \\
\hline Kwartyl & 2,60 & 3,75 & 2,53 & 1,04 & 2,44 & 3,74 & 2,91 & 1,46 \\
\hline Skośnośćn & 0,09 & $-0,42$ & 0,83 & $-0,16$ & 0,02 & $-0,15$ & $-0,21$ & $-0,05$ \\
\hline Kurtoza & $-1,56$ & $-0,17$ & 0,15 & $-1,58$ & $-1,42$ & $-1,34$ & $-1,55$ & $-1,55$ \\
\hline
\end{tabular}

Źródło: obliczenia własne.

W Euroregionie Pro Europa Viadrina maksymalna wartość wskaźnika Perkala wynosi 0,49 , minimalna wartość $-0,74$, odchylenie standardowe 0,42 , wariancja 0,18 , mediana 0,09 , średnia wartość wskaźnika 0,03, kurtoza $-0,75$. W Euroregionie Sprewa-Nysa-Bóbr maksymalna wartość wskaźnika Perkala wynosi 0,88, minimalna wartość $-0,61$, odchylenie standardowe 0,52 , wariancja 0,27 , mediana 0,24 , średnia wartość wskaźnika 0,16 , kurtoza -1,58. W Euroregionie Neisse -Nisa-Nysa maksymalna wartość wskaźnika Perkala wynosi 1,38, minimalna wartość -0,89, odchylenie standardowe 0,77 , wariancja 0,59 , mediana 0,44 , a średnia wartość wskaźnika 0,26, kurtoza -1,55.

Wskaźnik postępu (WP) zaprezentowany został na wykresie 7.3. Największy postęp w rozwoju odnotowano w Euroregionie Pomerania 2,2 oraz w Euroregionie Neisse-Nisa-Nysa 2,17. Najniższy zaś w Euroregionie Pro Europa Viadrina na poziomie 0,41 .

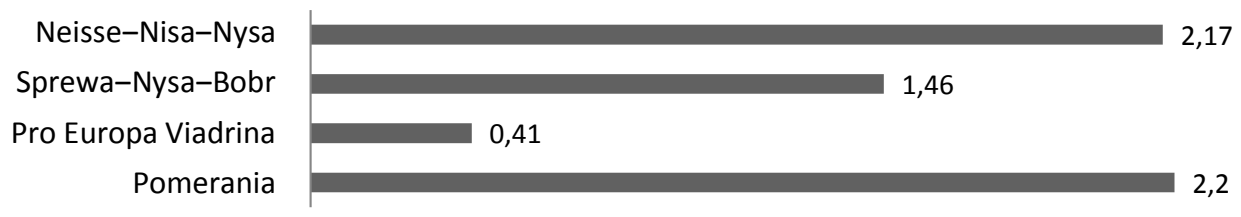

Wykres 7.3. Postęp $w$ euroregionach zachodniego pogranicza Polski na przestrzeni lat 2000-2014

Źródło: obliczenia własne. 
Można zauważyć, że największy postęp dotyczy euroregionów, które posiadają większe zasoby materialne i niematerialne, większą liczbę miast o dużym znaczeniu dla lokalnej gospodarki, potencjał ludzki, dobrze rozbudowaną sieć instytucji naukowych oraz szeroko rozwiniętą promocję współpracy transgranicznej.

Badanie potwierdziło, że występuje istotna statystycznie zależność pomiędzy zrównoważonym rozwojem poszczególnych euroregionów (tabela 7.4)

Tabela 7.4. Korelacje pomiędzy rozwojem poszczególnych euroregionów. Oznaczone współczynniki korelacji są istotne $z p<, 05000 \mathrm{~N}=15$

\begin{tabular}{|c|c|c|c|c|c|c|}
\hline & Średnia & $\begin{array}{c}\text { Odchylenie } \\
\text { standardowe }\end{array}$ & WrP & WrPEV & WrS-N-B & WrN-N-N \\
\hline$W r P$ & 0,815 & 3,733 & 1,000 & $\mathbf{0 , 6 7 1}$ & $\mathbf{0 , 9 1 8}$ & $\mathbf{0 , 9 5 7}$ \\
\hline$W r P E V$ & 0,181 & 2,533 & $\mathbf{0 , 6 7 1}$ & 1,000 & $\mathbf{0 , 8 7 4}$ & $\mathbf{0 , 7 8 7}$ \\
\hline$W r S-N-B$ & 0,953 & 3,138 & $\mathbf{0 , 9 1 8}$ & $\mathbf{0 , 8 7 4}$ & 1,000 & $\mathbf{0 , 9 5 0}$ \\
\hline$W r N-N-N$ & 1,524 & 4,606 & $\mathbf{0 , 9 5 7}$ & $\mathbf{0 , 7 8 7}$ & $\mathbf{0 , 9 5 0}$ & 1,000 \\
\hline
\end{tabular}

WrP - syntetyczny wskaźnik rozwoju Euroregionu Pomerania,

WrPEV - syntetyczny wskaźnik rozwoju Euroregionu Pro Europa Viadrina, WrS-N-B - syntetyczny wskaźnik rozwoju Euroregionu Sprewa-Nysa-Bóbr, $W r N-N-N$ - syntetyczny wskaźnik rozwoju Euroregionu Neisse-Nisa-Nysa.

Źródło: opracowanie własne.

Najwyższy poziom zależności 0,96 występuje pomiędzy rozwojem w Euroregionie Neisse-Nisa-Nysa i Pomerania. Wydaje się, że to konsekwencja zbliżonych uwarunkowań i potencjału społeczno-gospodarczego. Najniższy poziom korelacji odnotowano pomiędzy Euroregionem Pomerania i Pro Europa Viadrina, co z kolei może świadczyć o dużej dysproporcji potencjałów obu analizowanych obszarów.

Wskaźniki korelacji pomiędzy poszczególnymi składowymi rozwoju zrównoważonego zebrano w tabeli 7.5.

Tabela 7.5. Korelacje. Oznaczone współczynniki korelacji są istotne z $p<, 05000 N=15$

\begin{tabular}{|c|c|c|c|c|c|c|}
\hline \multicolumn{7}{|c|}{ Euroregion Pomerania } \\
\hline & Średnia & $\begin{array}{c}\text { Odchylenie } \\
\text { standardowe }\end{array}$ & $\begin{array}{c}\text { Wskaźnik } \\
\text { ekonomiczny }\end{array}$ & $\begin{array}{c}\text { Wskaźnik } \\
\text { społeczny }\end{array}$ & $\begin{array}{c}\text { Wskaźnik } \\
\text { śodowi- } \\
\text { skowy }\end{array}$ & $\begin{array}{c}\text { Wskaźnik } \\
\text { rozwoju }\end{array}$ \\
\hline $\begin{array}{c}\text { Wskaźnik } \\
\text { ekonomiczny }\end{array}$ & 0,000 & 0,926 & 1,000 & $\mathbf{0 , 8 8 0}$ & $\mathbf{0 , 5 9 7}$ & $\mathbf{0 , 9 3 5}$ \\
\hline $\begin{array}{c}\text { Wskaźnik } \\
\text { społeczny }\end{array}$ & 0,709 & 2,217 & $\mathbf{0 , 8 8 0}$ & 1,000 & $\mathbf{0 , 5 2 1}$ & $\mathbf{0 , 9 5 5}$ \\
\hline $\begin{array}{c}\text { Wskaźnik śro- } \\
\text { dowiskowy }\end{array}$ & 0,107 & 1,024 & $\mathbf{0 , 5 9 7}$ & $\mathbf{0 , 5 2 1}$ & 1,000 & $\mathbf{0 , 7 3 2}$ \\
\hline $\begin{array}{c}\text { Wskaźnik } \\
\text { rozwoju }\end{array}$ & 0,815 & 3,733 & $\mathbf{0 , 9 3 5}$ & $\mathbf{0 , 9 5 5}$ & $\mathbf{0 , 7 3 2}$ & 1,000 \\
\hline
\end{tabular}


Tabela 7.5. (cd.)

\begin{tabular}{|c|c|c|c|c|c|c|}
\hline \multicolumn{7}{|c|}{ Euroregion Pro Europa Viadrina } \\
\hline & Średnia & $\begin{array}{c}\text { Odchylenie } \\
\text { standardowe }\end{array}$ & $\begin{array}{c}\text { Wskaźnik } \\
\text { ekonomiczny }\end{array}$ & $\begin{array}{c}\text { Wskaźnik } \\
\text { społeczny }\end{array}$ & $\begin{array}{c}\text { Wskaźnik } \\
\text { środowi- } \\
\text { skowy }\end{array}$ & $\begin{array}{c}\text { Wskaźnik } \\
\text { rozwoju }\end{array}$ \\
\hline $\begin{array}{c}\text { Wskaźnik } \\
\text { ekonomiczny }\end{array}$ & 0,000 & 1,035 & 1,000 & $\mathbf{0 , 8 4 4}$ & $-\mathbf{0 , 5 8 9}$ & $\mathbf{0 , 7 8 6}$ \\
\hline $\begin{array}{c}\text { Wskaźnik } \\
\text { społeczny }\end{array}$ & 0,480 & 1,820 & $\mathbf{0 , 8 4 4}$ & 1,000 & $-0,256$ & $\mathbf{0 , 9 6 4}$ \\
\hline $\begin{array}{c}\text { Wskaźnik śro- } \\
\text { dowiskowy }\end{array}$ & $-0,299$ & 0,984 & $-\mathbf{0 , 5 8 9}$ & $-0,256$ & 1,000 & $-0,036$ \\
\hline $\begin{array}{c}\text { Wskaźnik } \\
\text { rozwoju }\end{array}$ & 0,181 & 2,533 & $\mathbf{0 , 7 8 6}$ & $\mathbf{0 , 9 6 4}$ & $-0,036$ & 1,000 \\
\hline
\end{tabular}

\begin{tabular}{|c|c|c|c|c|c|c|}
\hline \multicolumn{7}{|c|}{ Euroregion Sprewa-Nysa-Bóbr } \\
\hline & Średnia & $\begin{array}{c}\text { Odchylenie } \\
\text { standardowe }\end{array}$ & $\begin{array}{c}\text { Wskaźnik } \\
\text { ekonomiczny }\end{array}$ & $\begin{array}{c}\text { Wskaźnik } \\
\text { społeczny }\end{array}$ & $\begin{array}{c}\text { Wskaźnik } \\
\text { środowi- } \\
\text { skowy }\end{array}$ & $\begin{array}{c}\text { Wskaźnik } \\
\text { rozwoju }\end{array}$ \\
\hline $\begin{array}{c}\text { Wskaźnik } \\
\text { ekonomiczny }\end{array}$ & 0,565 & 1,260 & 1,000 & $\mathbf{0 , 9 3 6}$ & $\mathbf{- 0 , 7 0 4}$ & $\mathbf{0 , 9 1 2}$ \\
\hline $\begin{array}{c}\text { Wskaźnik } \\
\text { społeczny }\end{array}$ & 0,888 & 2,792 & $\mathbf{0 , 9 3 6}$ & 1,000 & $-0,702$ & 0,944 \\
\hline $\begin{array}{c}\text { Wskaźnik śro- } \\
\text { dowiskowy }\end{array}$ & $-0,500$ & 1,435 & $\mathbf{- 0 , 7 0 4}$ & $\mathbf{- 0 , 7 0 2}$ & 1,000 & $-0,450$ \\
\hline $\begin{array}{c}\text { Wskaźnik } \\
\text { rozwoju }\end{array}$ & 0,953 & 3,138 & $\mathbf{0 , 9 1 2}$ & $\mathbf{0 , 9 4 4}$ & $-0,450$ & 1,000 \\
\hline
\end{tabular}

\begin{tabular}{|c|c|c|c|c|c|c|}
\hline \multicolumn{7}{|c|}{ Euroregion Neisse-Nisa-Nysa } \\
\hline & Średnia & $\begin{array}{c}\text { Odchylenie } \\
\text { standardowe }\end{array}$ & $\begin{array}{c}\text { Wskaźnik } \\
\text { ekonomiczny }\end{array}$ & $\begin{array}{c}\text { Wskaźnik } \\
\text { społeczny }\end{array}$ & $\begin{array}{c}\text { Wskaźnik } \\
\text { środowi- } \\
\text { skowy }\end{array}$ & $\begin{array}{c}\text { Wskaźnik } \\
\text { rozwoju }\end{array}$ \\
\hline $\begin{array}{c}\text { Wskaźnik } \\
\text { ekonomiczny }\end{array}$ & 0,425 & 1,281 & 1,000 & $\mathbf{0 , 9 2 2}$ & $\mathbf{0 , 8 6 0}$ & $\mathbf{0 , 9 6 1}$ \\
\hline $\begin{array}{c}\text { Wskaźnik } \\
\text { społeczny }\end{array}$ & 0,609 & 2,012 & $\mathbf{0 , 9 2 2}$ & 1,000 & $\mathbf{0 , 8 6 6}$ & 0,975 \\
\hline $\begin{array}{c}\text { Wskaźnik śro- } \\
\text { dowiskowy }\end{array}$ & 0,491 & 1,498 & $\mathbf{0 , 8 6 0}$ & $\mathbf{0 , 8 6 6}$ & 1,000 & $\mathbf{0 , 9 4 3}$ \\
\hline $\begin{array}{c}\text { Wskaźnik } \\
\text { rozwoju }\end{array}$ & 1,524 & 4,606 & $\mathbf{0 , 9 6 1}$ & $\mathbf{0 , 9 7 5}$ & $\mathbf{0 , 9 4 3}$ & 1,000 \\
\hline
\end{tabular}

Źródło: opracowanie własne.

Zgodnie z wyznaczonymi współczynnikami korelacji liniowej Pearsona w każdymzanalizowanych euroregionów można dostrzec wysoki poziom istotnej statystycznie zależności pomiędzy rozwojem gospodarczym, społecznym i środowiskowym.

Należy jednakże zauważyć, że wyższe wskaźniki Pearsona uzyskano dla korelacji pomiędzy rozwojem ekonomicznym i społecznym (wynoszą one powyżej $80 \%$ ). Natomiast niższa korelacja występuje pomiędzy rozwojem gospodarczym 
i środowiskowym oraz społecznym i środowiskowym (powyżej 50\%). Wydaje się, że otrzymane wyniki są zgodne z faktycznym stanem poziomu rozwoju społeczno-gospodarczego obszarów transgranicznych. Można również stwierdzić, że w pierwszej kolejności zarządzający obszarami współpracy transgranicznej kładą nacisk na rozwój społeczno-gospodarczy, a dopiero w dalszej kolejności podejmują działania ukierunkowane na rozwój środowiska naturalnego.

Wyniki estymacji Klasyczną Metodą Najmniejszych Kwadratów przedstawiono w tabeli 7.6. Badanie przeprowadzono oddzielnie dla każdego z euroregionów, tworząc model regresji liniowej prostej (zmienna zależna uzależniona została od jednej zmiennej niezależnej).

Tabela 7.6. Estymacja KMNK, wykorzystane obserwacje 2000-2014 ( $N=15)$

\begin{tabular}{|c|c|c|c|c|c|c|c|}
\hline \multicolumn{8}{|c|}{ Euroregion Pomerania } \\
\hline & $b^{*}$ & $\begin{array}{c}\text { Błąd } \\
\text { standardowy } z b^{*}\end{array}$ & $b$ & Błąd standardowy z $b$ & $t(11)$ & $p$ & $R^{2}$ \\
\hline $\begin{array}{l}\text { Wyraz } \\
\text { wolny }\end{array}$ & & & 0,64 & 0,74 & 0,86 & 0,41 & \multirow[t]{2}{*}{0,45} \\
\hline WrPEV & 0,67 & 0,21 & 0,99 & 0,30 & 3,26 & 0,01 & \\
\hline $\begin{array}{l}\text { Wyraz } \\
\text { wolny }\end{array}$ & & & $-0,23$ & 0,42 & $-0,54$ & 0,60 & \multirow[t]{2}{*}{0,84} \\
\hline$W r S-N-B$ & 0,92 & 0,11 & 1,09 & 0,13 & 8,36 & 0,00 & \\
\hline $\begin{array}{l}\text { Wyraz } \\
\text { wolny }\end{array}$ & & & $-0,37$ & 0,31 & $-1,19$ & 0,25 & \multirow[t]{2}{*}{0,92} \\
\hline WrN-N-N & 0,96 & 0,08 & 0,78 & 0,07 & 11,87 & 0,00 & \\
\hline
\end{tabular}

\begin{tabular}{|c|c|c|c|c|c|c|c|}
\hline \multicolumn{8}{|c|}{ Euroregion Pro Europa Viadrina } \\
\hline $\begin{array}{l}\text { Wyraz } \\
\text { wolny }\end{array}$ & & & $-0,19$ & 0,52 & $-0,37$ & 0,72 & \multirow{2}{*}{0,45} \\
\hline WrPom & 0,67 & 0,21 & 0,46 & 0,14 & 3,26 & 0,01 & \\
\hline $\begin{array}{l}\text { Wyraz } \\
\text { wolny }\end{array}$ & & & $-0,49$ & 0,35 & $-1,42$ & 0,18 & \multirow[t]{2}{*}{0,76} \\
\hline$W r S-N-B$ & 0,87 & 0,13 & 0,71 & 0,11 & 6,48 & 0,00 & \\
\hline $\begin{array}{l}\text { Wyraz } \\
\text { wolny }\end{array}$ & & & $-0,48$ & 0,44 & $-1,08$ & 0,30 & \multirow[t]{2}{*}{0,62} \\
\hline$W r N-N-N$ & 0,79 & 0,17 & 0,43 & 0,09 & 4,61 & 0,00 & \\
\hline
\end{tabular}

\begin{tabular}{|c|c|c|c|c|c|c|c|}
\hline \multicolumn{8}{|c|}{ Euroregion Sprewa-Nysa-Bóbr } \\
\hline $\begin{array}{l}\text { Wyraz } \\
\text { wolny }\end{array}$ & & & 0,32 & 0,34 & 0,95 & 0,36 & \multirow{2}{*}{0,84} \\
\hline WrPom & 0,92 & 0,11 & 0,77 & 0,09 & 8,36 & 0,00 & \\
\hline $\begin{array}{l}\text { Wyraz } \\
\text { wolny }\end{array}$ & & & 0,76 & 0,41 & 1,85 & 0,09 & \multirow{2}{*}{0,76} \\
\hline WrPEV & 0,87 & 0,13 & 1,08 & 0,17 & 6,48 & 0,00 & \\
\hline $\begin{array}{l}\text { Wyraz } \\
\text { wolny }\end{array}$ & & & $-0,03$ & 0,28 & $-0,12$ & 0,90 & \multirow[t]{2}{*}{0,90} \\
\hline WrN-N-N & 0,95 & 0,09 & 0,65 & 0,06 & 11,01 & 0,00 & \\
\hline
\end{tabular}


Tabela 7.6. (cd.)

\begin{tabular}{|c|c|c|c|c|c|c|c|}
\hline \multicolumn{8}{|c|}{ Euroregion Neisse-Nisa-Nysa } \\
\hline $\begin{array}{l}\text { Wyraz } \\
\text { wolny }\end{array}$ & & & 0,56 & 0,37 & 1,53 & 0,15 & \multirow{2}{*}{0,92} \\
\hline WrPom & 0,96 & 0,08 & 1,18 & 0,10 & 11,87 & 0,00 & \\
\hline $\begin{array}{l}\text { Wyraz } \\
\text { wolny }\end{array}$ & & & 1,27 & 0,76 & 1,66 & 0,12 & \multirow{2}{*}{0,62} \\
\hline WrPEV & 0,79 & 0,17 & 1,43 & 0,31 & 4,61 & 0,00 & \\
\hline $\begin{array}{l}\text { Wyraz } \\
\text { wolny }\end{array}$ & & & 0,19 & 0,40 & 0,48 & 0,64 & \multirow[t]{2}{*}{0,90} \\
\hline WrS-N-B & 0,95 & 0,09 & 1,39 & 0,13 & 11,01 & 0,00 & \\
\hline
\end{tabular}

$b^{*}$ - szacowana wartość parametru przy zmiennej objaśniającej,

$b$ - współczynnik regresji,

$t(11)$ - statystyka t-Studenta,

$p$ - prawdopodobieństwo popełnienia błędu przy odrzuceniu hipotezy zerowej,

$R^{2}$ - współczynnik determinacji,

WrPom - syntetyczny wskaźnik rozwoju Euroregionu Pomerania,

WrPEV - syntetyczny wskaźnik rozwoju Euroregionu Pro Europa Viadrina,

WrS-N-B- syntetyczny wskaźnik rozwoju Euroregionu Sprewa-Nysa-Bóbr,

$W r N-N-N$ - syntetyczny wskaźnik rozwoju Euroregionu Neisse-Nisa-Nysa.

Źródło: obliczenia własne.

Zgodnie z wyznaczonymi współczynnikami determinacji (określającymi stosunek zmienności zmiennej objaśnionej przez równanie do całkowitej zmienności zmiennej objaśnianej ${ }^{8}$ ) można zauważyć wysoki stopień objaśnienia zmiennej zależnej. Najniższy stopień objaśnienia ma miejsce w przypadku funkcyjnej oceny zależności pomiędzy rozwojem Euroregionu Pro Europa Viadrina i Euroregionu Neisse-Nisa-Nysa (45\%). Uzyskane współczynniki determinacji dla pozostałych zależności są na wyższym poziomie. Najwyższy poziom współczynnika determinacji wynoszący $92 \%$ odnotowano $\mathrm{w}$ przypadku badania zależności pomiędzy Euroregionem Pomerania i Euroregionem Neisse-Nisa-Nysa. Pogrubione wartości otrzymanych parametrów są istotne statystycznie i mają wpływ na kształtowanie się zmiennej zależnej są istotne statystycznie na poziomie 0,005 (ocena istotności przeprowadzona zgodnie $\mathrm{z}$ testem $\mathrm{t}$-Studenta).

Dokonując podsumowania wyników regresji, można dostrzec zależność funkcyjną pomiędzy rozwojem we wszystkich analizowanych euroregionach. W każdym przypadku jest to zależność dodatnia, zatem można stwierdzić, że rozwój jednego euroregionu prowadzi do rozwoju pozostałych euroregionów na zachodniej granicy Polski.

Wyniki prognozy wskaźnika Perkala dla analizowanych euroregionów pokazują, że w każdym z analizowanych obszarów współpracy transgranicznej będzie miał miejsce dalszy rozwój (wykres 7.4).

8 J.B. Gajda, Ekonometria, Wydawnictwo C.H. Beck, Warszawa 2004, s. 50. 


\begin{tabular}{|c|c|c|c|c|c|c|c|}
\hline \\
\hline \multirow{4}{*}{ 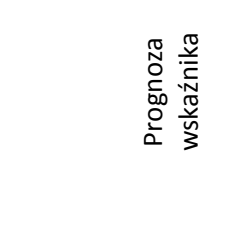 } & \multirow{3}{*}{$\begin{array}{r}2,5 \\
2 \\
1,5 \\
1 \\
0,5\end{array}$} & \multicolumn{6}{|c|}{ 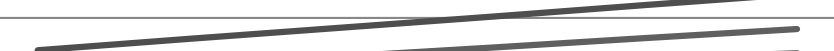 } \\
\hline & & \\
\hline & & \\
\hline & 0 & 2015 & 2016 & 2017 & 2018 & 2019 & 2020 \\
\hline Pomerania & & 1,18 & 1,32 & 1,45 & 1,58 & 1,71 & 1,84 \\
\hline Pro Europa Vi & adrina & 0,56 & 0,62 & 0,69 & 0,76 & 0,82 & 0,89 \\
\hline Sprewa-Nysa & -Bobr & 0,98 & 1,09 & 1,19 & 1,29 & 1,4 & 1,5 \\
\hline Neisse-Nisa-I & Jysa & 1,54 & 1,7 & 1,86 & 2,02 & 2,18 & 2,34 \\
\hline
\end{tabular}

Wykres 7.4. Prognoza rozwoju euroregionów w latach 2015-2020

Źródło: obliczenia własne.

W Euroregionie Pomerania w 2015 r. wskaźnik Perkala wyniósł 1,18, a w 2020 r. wzrośnie do poziomu 1,84. W Euroregionie Pro Europa Viadrina wzrośnie z poziomu 0,56 do 0,89, w Euroregionie Sprewa-Nysa-Bóbr z poziomu 0,98 do 1,5, a w Euroregionie Neisse-Nisa-Nysa z poziomu 1,54 do 2,34.

\section{Funkcja dominująca euroregionu}

Wyznaczone wskaźniki Florence’a dla Euroregionów w 2014 r. zebrano w tabeli 7.7. Wartości współczynników wyższe od jedności wskazują na działalność o charakterze egzogenicznym.

Najwyższe współczynniki Florence’a w Euroregionie Pomerania uzyskano dla działów: Zakwaterowanie i gastronomia $(1,94)$, Administracja $(1,36)$, Transport i gospodarka magazynowa $(1,23)$. Najwyższe współczynniki Florence’a w Euroregionie Pro Europa Viadrina uzyskano dla działów: Transport i gospodarka magazynowa $(1,25)$, Administracja publiczna i obrona narodowa, Obowiązkowe zabezpieczenia społeczne $(1,2)$, Pozostała działalność usługowa $(1,18)$. W Euroregionie Sprewa-Nysa-Bóbr dla Transport i działalność magazynowa $(1,13)$, Handel $(1,08)$ oraz Budownictwo $(1,05)$. W Euroregionie Neisse-Nisa-Nysa najwyższe wskaźniki uzyskano dla działu Administrowanie i działalność wspierająca $(1,57)$, Informacja i komunikacja $(1,32)$, Zakwaterowanie i gastronomia $(1,22)$.

Najniższe wartości wskaźnika Florence’a, wskazujące na endogeniczny charakter działalności, odnotowano dla działu Rolnictwo, leśnictwo i rybołówstwo $(0,59)$ w Euroregionie Pomerania; Informacja i komunikacja $(0,46)$ w Euroregionie Pro Europa Viadrina; Informacja i komunikacja $(0,73)$ i Działalność Finansowa w Euroregionie Sprewa-Nysa-Bóbr oraz Rolnictwo, leśnictwo, łowiectwo i rybactwo $(0,5)$ w Euroregionie Neisse-Nisa-Nysa. 
Tabela 7.7. Wskaźnik Florence'a w Euroregionach zachodniego pogranicza Polski w 2014 r.

\begin{tabular}{|c|c|c|c|c|}
\hline \multirow[b]{2}{*}{ Działy gospodarki } & \multicolumn{4}{|c|}{ Wskaźnik Florence'a } \\
\hline & $\begin{array}{l}\text { Pomera- } \\
\text { nia }\end{array}$ & $\begin{array}{l}\text { Pro Europa } \\
\text { Viadrina }\end{array}$ & \begin{tabular}{|c|} 
Sprewa \\
-Nysa-Bóbr
\end{tabular} & $\begin{array}{c}\text { Neisse } \\
\text {-Nisa-Nysa }\end{array}$ \\
\hline $\begin{array}{c}\text { Rolnictwo, leśnictwo, łowiectwo } \\
\text { i rybactwo }\end{array}$ & 0,59 & 0,68 & 0,86 & 0,50 \\
\hline Budownictwo & 1,13 & 0,93 & 1,05 & 1,02 \\
\hline $\begin{array}{l}\text { Handel; naprawa pojazdów } \\
\text { samochodowych }\end{array}$ & 1,07 & 1,04 & 1,08 & 0,98 \\
\hline Transport i gospodarka magazynowa & 1,23 & 1,25 & 1,13 & 0,99 \\
\hline Zakwaterowanie i gastronomia & 1,94 & 0,92 & 0,84 & 1,22 \\
\hline Informacja i komunikacja & 0,79 & 0,46 & 0,73 & 1,32 \\
\hline $\begin{array}{l}\text { Działalność finansowa } \\
\text { i ubezpieczeniowa }\end{array}$ & 0,83 & 0,73 & 0,73 & 1,12 \\
\hline Obsługa rynku nieruchomości & 1,11 & 0,92 & 0,88 & 1,02 \\
\hline $\begin{array}{c}\text { Działalność profesjonalna, naukowa } \\
\text { i techniczna }\end{array}$ & 0,85 & 0,65 & 0,87 & 1,17 \\
\hline $\begin{array}{c}\text { Administrowanie i działalność } \\
\text { wspierająca }\end{array}$ & 0,90 & 1,08 & 1,03 & 1,57 \\
\hline $\begin{array}{l}\text { Administracja publiczna i obrona } \\
\text { narodowa, obowiązkowe } \\
\text { zabezpieczenia społeczne }\end{array}$ & 1,36 & 1,20 & 0,86 & 0,99 \\
\hline Edukacja & 1,15 & 1,01 & 0,94 & 0,99 \\
\hline Opieka zdrowotna i pomoc społeczna & 1,15 & 0,98 & 0,83 & 1,11 \\
\hline $\begin{array}{c}\text { Działalność związana z kulturą, } \\
\text { rozrywką i rekreacją }\end{array}$ & 1,14 & 0,97 & 0,81 & 1,11 \\
\hline Pozostała działalność usługowa & 1,18 & 1,18 & 0,96 & 0,99 \\
\hline
\end{tabular}

Źródło: obliczenia własne.

\section{Wpływ funduszy unijnych na zrównoważony rozwój euroregionów}

Statystyczna ocena wpływu środków z Unii Europejskiej na zrównoważony rozwój euroregionów niesie ze sobą poważny problem badawczy. W świetle dostępnej literatury przedmiotu oraz opinii badaczy niezasadne jest zbadanie zależności liniowej czy funkcyjnej przy pomocy współczynnika korelacji linowej Pearsona czy wykorzystaniu statystycznej analizy regresji ze względu na stosunkowo niski poziom całkowitego dofinansowania ze środków wspólnotowych. Opinię taką potwierdziła przeprowadzona analiza zależności liniowej i funkcyjnej pomiędzy przekazanymi funduszami w okresach rocznych a zrównoważonym rozwojem euroregionów zachodniego pogranicza Polski. Dlatego też weryfikację głównej hipotezy przeprowadzono $\mathrm{w}$ dwóch etapach: wyznaczono wskaźnik absorpcji środków z Funduszu Małych Projektów UE, a następnie wyznaczono zależność liniową 
pomiędzy wskaźnikiem postępu w euroregionach a przekazanym całkowitym dofinansowaniem $\mathrm{z}$ unijnej polityki regionalnej.

Wyznaczony wskaźnik absorbcji funduszy UE przyjął wartości od 0,17 do 4,7 (tabela 7.8). Euroregion Sprewa-Nysa-Bóbr pozyskuje z funduszy europejskich najwięcej środków finansowych przypadających na mieszkańca. Poziom wykorzystania FMP w Euroregionach Neisse-Nisa-Nysa i Euroregionie Pro Europa Viadrina jest na podobnym poziomie. Najsłabsze poziomy wskaźnika odnotowane natomiast zostały w Euroregionie Pomerania, gdzie wykorzystanie FMP wahało się na poziomie $0,31 \mathrm{w} 2009 \mathrm{r}$. do $0,17 \mathrm{w}$ roku $2014 \mathrm{r}$.

Tabela 7.8. Wskaźnik absorbcji środków z Funduszu Małych Projektów w euroregionach

\begin{tabular}{|c|c|c|c|c|c|c|}
\hline \multirow{2}{*}{ Euroregion } & \multicolumn{7}{|c|}{ Rok } \\
\cline { 2 - 7 } & 2009 & 2010 & 2011 & 2012 & 2013 & 2014 \\
\hline Pro Europa Viadrina & 0,43 & 0,68 & 0,65 & 0,59 & 0,54 & 0,62 \\
\hline Sprewa-Nysa-Bóbr & 0,58 & 4,70 & 2,88 & 1,35 & 2,04 & 2,18 \\
\hline Neisse-Nisa-Nysa & 0,45 & 0,65 & 0,69 & 0,74 & 0,49 & 0,65 \\
\hline Pomerania & 0,31 & 0,35 & 0,22 & 0,26 & 0,19 & 0,17 \\
\hline
\end{tabular}

Źródło: obliczenia własne na podstawie danych z Sekretariatów Euroregionów.

Zależność pomiędzy różnicą wskaźnika Perkala $\mathrm{w}$ euroregionach $\mathrm{w}$ latach 2000-2014 (wskaźnika postępu) a wartością środków finansowych przekazanych w ramach funduszy unijnych na rzecz współpracy transgranicznej (analizowana jest całość środków przekazywanych w ramach EWT) przedstawiono na wykresie 7.5.

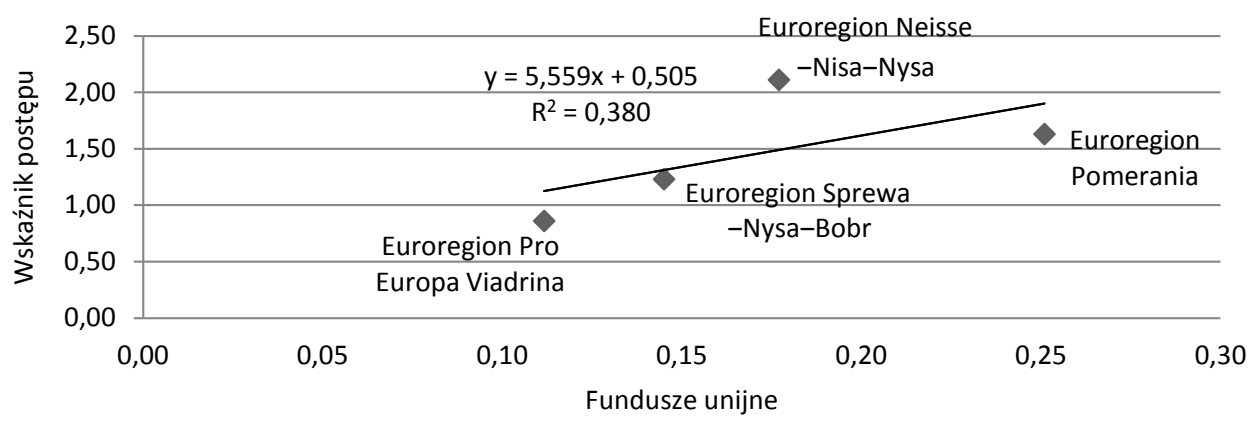

Wykres 7.5. Zależność między zrównoważonym rozwojem euroregionów a przekazanym dofinansowaniem z UE

Źródło: opracowanie własne. 
Wyznaczona linia trendu jest rosnąca, co oznacza, że napływ środków z funduszy europejskich z programów Europejskiej Współpracy Terytorialnej na rzecz rozwoju obszarów transgranicznych jest wprost proporcjonalny do zrównoważonego rozwoju euroregionów zachodniego pogranicza Polski. Równanie wyznaczonej linii trendu przyjęło następującą postać:

$$
Y=5,559 x+0,505
$$

gdzie:

$Y$ - postęp w zrównoważonym rozwoju euroregionów w latach 2001-2013, $x$ - środki unijne przekazane w ramach EWT w latach 2001-2013 (mld euro).

Analizując rozkład poszczególnych euroregionów względem linii trendu, łatwo zauważyć, że jedynym obszarem sformalizowanej współpracy transgranicznej znajdującym się powyżej wyznaczonej linii trendu jest Euroregion Neisse -Nisa-Nysa. Należy zatem stwierdzić, że Euroregion ten jako jedyny wykorzystuje efektywnie środki unijnej polityki regionalnej, co znajduje swoje odzwierciedlenie $\mathrm{w}$ istotnym wpływie środków z UE na zrównoważony rozwój jego obszaru. Pozostałe euroregiony znajdują się nieznacznie poniżej wyznaczonej linii trendu. Należy odnotować, że największe dofinansowanie z Unii Europejskiej uzyskał Euroregion Pomerania, a najmniejsze Euroregion Pro Europa Viadrina.

Euroregion Neisse-Nisa-Nysa w największym stopniu wykorzystał szansę, jaką dało mu wdrażanie unijnej polityki regionalnej. Euroregiony Pomerania, Pro Europa Viadrina i Sprewa-Nysa-Bóbr charakteryzują się gorszym wykorzystaniem dostępnych środków.

Przeprowadzona analiza pomiędzy wielkościami wskaźnika Perkala dla euroregionów a funduszami unijnymi w poszczególnych latach nie wykazała istotnego statystycznie związku. Wydaje się jednak, że charakter rozwoju i jego ciągłość są rezultatem wieloletniego procesu zmian i działań ukierunkowanych na jego pobudzanie. Zasadnym zatem z punktu widzenia statystycznej analizy jest przeprowadzenie oceny wpływu, jaki miały skumulowane wartości przepływów pieniężnych z Unii Europejskiej na zrównoważony rozwój euroregionów zachodniego pogranicza Polski. Wyniki korelacji dla tak sformułowanego badania przedstawiono na wykresie 7.6.

Wyniki korelacji pokazują, że pomiędzy analizowanymi zmiennymi występuje silna i bardzo silna istotna statystycznie zależność. Najwyższe wskaźniki korelacji Pearsona odnotowano w Euroregionie Pomerania $(0,93)$ i w Euroregionie Neisse-Nisa-Nysa $(0,91)$, najniższe zaś w Euroregionie Pro Europa Viadrina $(0,73)$. Można zatem stwierdzić, że skumulowane wartości środków finansowych przekazywanych w ramach polityki regionalnej mają pozytywny i znaczący wpływ na rozwój euroregionów zachodniego pogranicza Polski. 


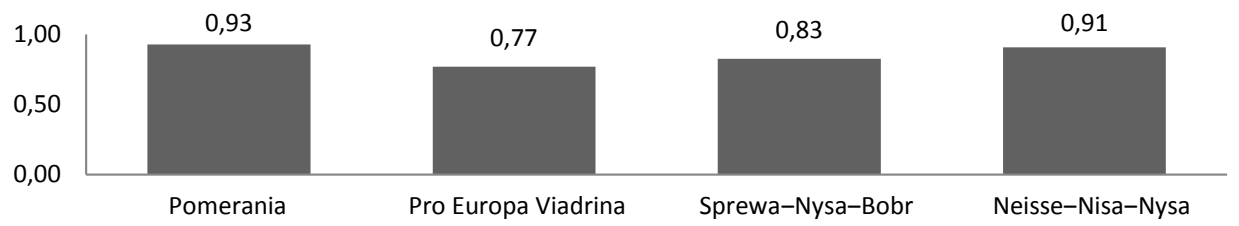

Wykres 7.6. Korelacje dla wskaźnika Perkala i skumulowanych przepływów Pieniężnych z Programów EWT dla lat 2000-2014

Źródło: obliczenia własne.

W tak skonstruowanym modelu można zauważyć również istotną zależność funkcyjną pomiędzy analizowanymi zmiennymi (tabela 7.9).

Tabela 7.9. Wyniki statystycznej analizy regresji (Klasyczna Metoda Najmniejszych Kwadratów) dla zmiennych Zrównoważony rozwój i Skumulowane przepływy środków z UE

\begin{tabular}{|c|c|c|c|c|c|c|c|c|}
\hline & $n=13$ & $b^{*}$ & $\begin{array}{c}\text { Błąd } \\
\text { standar- } \\
\text { dowy } b^{*}\end{array}$ & $b$ & $\begin{array}{c}\text { Błąd } \\
\text { standar- } \\
\text { dowy z } b\end{array}$ & $t(11)$ & $p$ & $R^{2}$ \\
\hline \multirow{2}{*}{$\begin{array}{l}\text { Euro- } \\
\text { region } \\
\text { Pomera- } \\
\text { nia }\end{array}$} & W. wolny & & & $-0,597605$ & 0,107745 & $-5,54648$ & 0,00017 & \multirow[b]{2}{*}{0,86} \\
\hline & $\begin{array}{c}\text { Fundusze } \\
\text { UE }\end{array}$ & 0,926462 & 0,113486 & 0,005810 & 0,000712 & 8,16369 & 0,00005 & \\
\hline
\end{tabular}

\begin{tabular}{|c|c|c|c|c|c|c|c|c|}
\hline \multirow{2}{*}{$\begin{array}{c}\text { Eurore- } \\
\text { gion Pro } \\
\text { Europa } \\
\text { Viadrina }\end{array}$} & $\begin{array}{l}\text { Wyraz } \\
\text { wolny }\end{array}$ & & & $-0,594790$ & 0,167194 & $-3,55748$ & 0,00443 & \multirow{2}{*}{0,59} \\
\hline & $\begin{array}{c}\text { Fundusze } \\
\text { UE }\end{array}$ & 0,768988 & 0,192745 & 0,009613 & 0,002409 & 3,98966 & 0,00213 & \\
\hline
\end{tabular}

\begin{tabular}{|c|c|c|c|c|c|c|c|c|}
\hline \multirow{2}{*}{$\begin{array}{l}\text { Euro- } \\
\text { region } \\
\text { Sprewa } \\
\text {-Nysa } \\
\text {-Bóbbr }\end{array}$} & $\begin{array}{l}\text { Wyraz } \\
\text { wolny }\end{array}$ & & & $-0,530960$ & 0,162668 & $-3,26408$ & 0,00754 & \multirow{2}{*}{0,68} \\
\hline & $\begin{array}{c}\text { Fundusze } \\
\text { UE }\end{array}$ & 0,825488 & 0,170179 & 0,008656 & 0,001784 & 4,85071 & 0,00050 & \\
\hline
\end{tabular}

\begin{tabular}{|c|c|c|c|c|c|c|c|c|}
\hline \multirow{2}{*}{$\begin{array}{c}\text { Euro- } \\
\text { region } \\
\text { Neisse } \\
\text {-Nisa } \\
\text {-Nvsa }\end{array}$} & $\begin{array}{l}\text { Wyraz } \\
\text { wolny }\end{array}$ & & & $-0,707878$ & 0,158396 & $-4,46903$ & 0,00098 & \multirow{2}{*}{0,82} \\
\hline & $\begin{array}{c}\text { Fundusze } \\
\text { UE }\end{array}$ & 0,907464 & 0,126674 & 0,011085 & 0,001547 & 7,16379 & 0,00008 & \\
\hline
\end{tabular}

$b^{*}$ - szacowana wartość parametru przy zmiennej objaśniającej,

$b$ - współczynnik regresji,

$t(11)$ - statystyka t-Studenta,

p - prawdopodobieństwo popełnienia błędu przy odrzuceniu hipotezy zerowej,

$R^{2}$ - współczynnik determinacji.

Źródło: obliczenia własne. 
Uzyskany współczynnik determinacji $R^{2}$ określający stosunek zmienności objaśnianej przez równanie do całkowitej zmienności zmiennej objaśnianej dla wpływu funduszy unijnych na zrównoważony rozwój Euroregionu Pomerania przyjął wartość $86 \%$, zatem za pomocą równania udało się objaśnić $86 \%$ zmienności zmiennej objaśnianej. W przypadku Euroregionu Pro Europa Viadrina współczynnik determinacji wyniósł 59\%, dla wpływu funduszy na rozwój Euroregionu Sprewa-Nysa-Bóbr wyniósł 68\%, a dla Euroregionu Neisse-Nisa-Nysa - 82\%. Wyznaczony współczynnik determinacji wskazuje na wysokie dopasowanie równania do zmiennych empirycznych.

Wyznaczone równania regresji przyjęły następującą postać:

$$
\begin{aligned}
& W P_{\text {Pomerania }}=-0,597605+0,005810 * \text { Fundusze UE } \\
& W P_{\text {ProEuropaViadrina }}=-0,594790+0,009613 * \text { Fundusze UE } \\
& W P_{\text {Sprewa-Nysa-Bóbr }}=-0,530960+0,008656 * \text { Fundusze UE } \\
& W P_{\text {Neiss-Nisa-Nysa }}=-0,707878+0,011085 * \text { Fundusze UE }
\end{aligned}
$$

Otrzymane dodatnie znaki przy współczynnikach stojących przy zmiennej Fundusze UE świadczą o dodatnim wpływie przepływów pieniężnych na zrównoważony rozwój w euroregionach. Oszacowane parametry przyjęły następujące wartości:

- $b_{1}=0,00581$ dla Euroregionu Pomerania, zatem wzrost funduszy o $1 \mathrm{mln}$ euro spowoduje wzrost wskaźnika o 0,0058,

- $b_{1}=0,009613$ dla Euroregionu Pro Europa Viadrina, zatem wzrost funduszy o 1 mln euro spowoduje wzrost wskaźnika o 0,009613,

- $b_{1}=0,008565$ dla Euroregionu Sprewa-Nysa-Bóbr, zatem wzrost funduszy o 1 mln euro spowoduje wzrost wskaźnika o 0,008565,

- $b_{1}=0,011085$ dla Euroregionu Neisse-Nisa-Nysa, zatem wzrost funduszy o $1 \mathrm{mln}$ euro spowoduje wzrost wskaźnika o 0,011085.

Do sprawdzenia istotności parametrów wykorzystano test t-Studenta, postawiono hipotezę zerową: $\mathrm{H}_{0}=0$ oraz hipotezę alternatywną $\mathrm{H}_{1} \neq 0$. Sprawdzianem hipotezy $\mathrm{H}_{0}$ jest statystyka $t\left(b_{j}\right)=b_{j} / S\left(b_{j}\right)$.

W każdym równaniu uzyskano statystyki $t\left(b_{1}\right)$ większe od wartości krytycznych odczytanych $\mathrm{z}$ tablic, zatem odrzucono hipotezę $\mathrm{H}_{0}$ na rzecz $\mathrm{H}_{1}$. Wszystkie uzyskane parametry są istotne statystycznie, więc w każdym $\mathrm{z}$ analizowanych euroregionów zmienna objaśniająca istotnie wpływa na zmienną objaśnianą.

Błąd standardowy danej statystyki, będący odchyleniem standardowym rozkładu tej wartości z prób we wszystkich analizowanych równaniach jest na niskim poziomie, zatem należy stwierdzić, że przewidywane wartości parametrów są dokładne. 


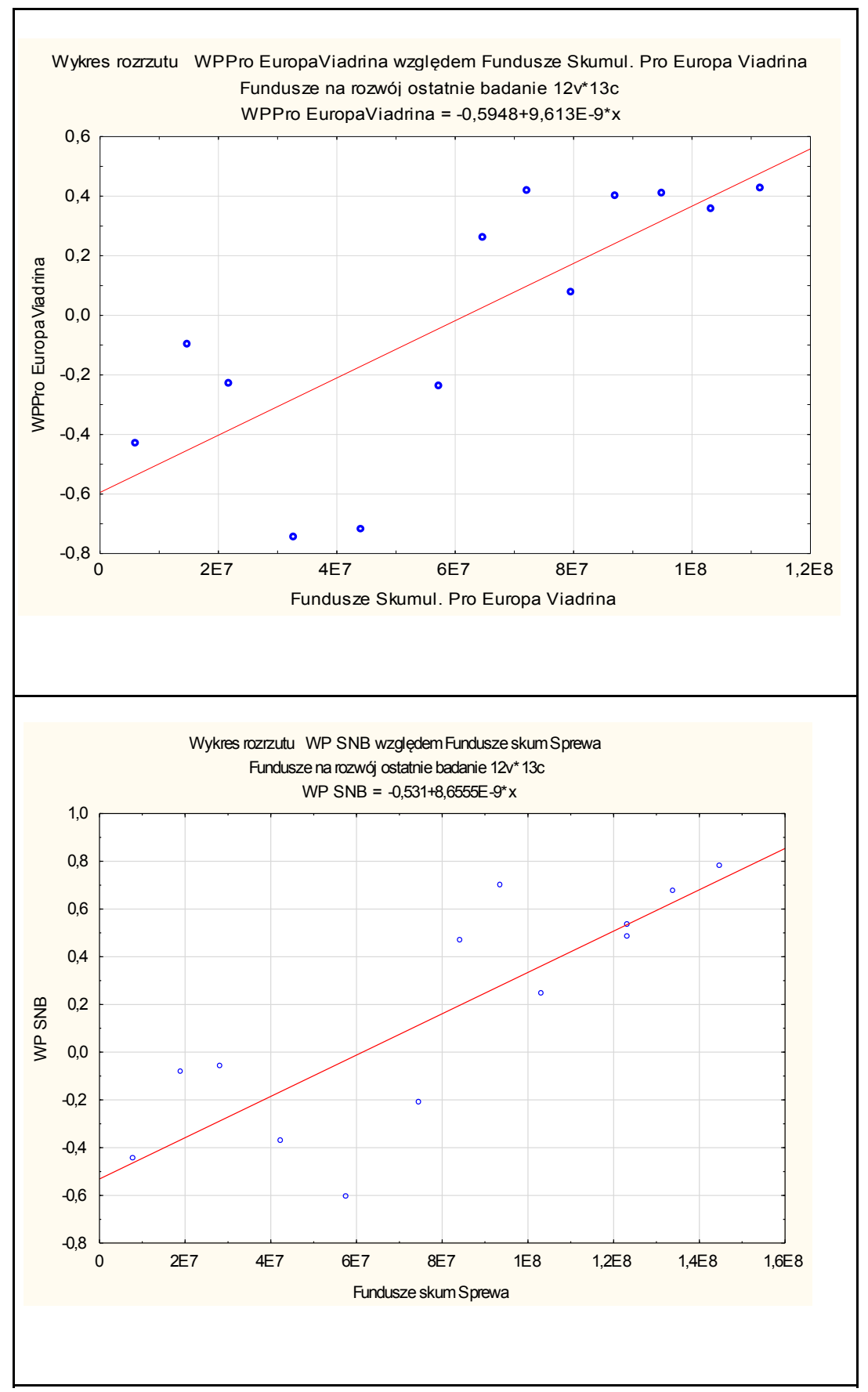




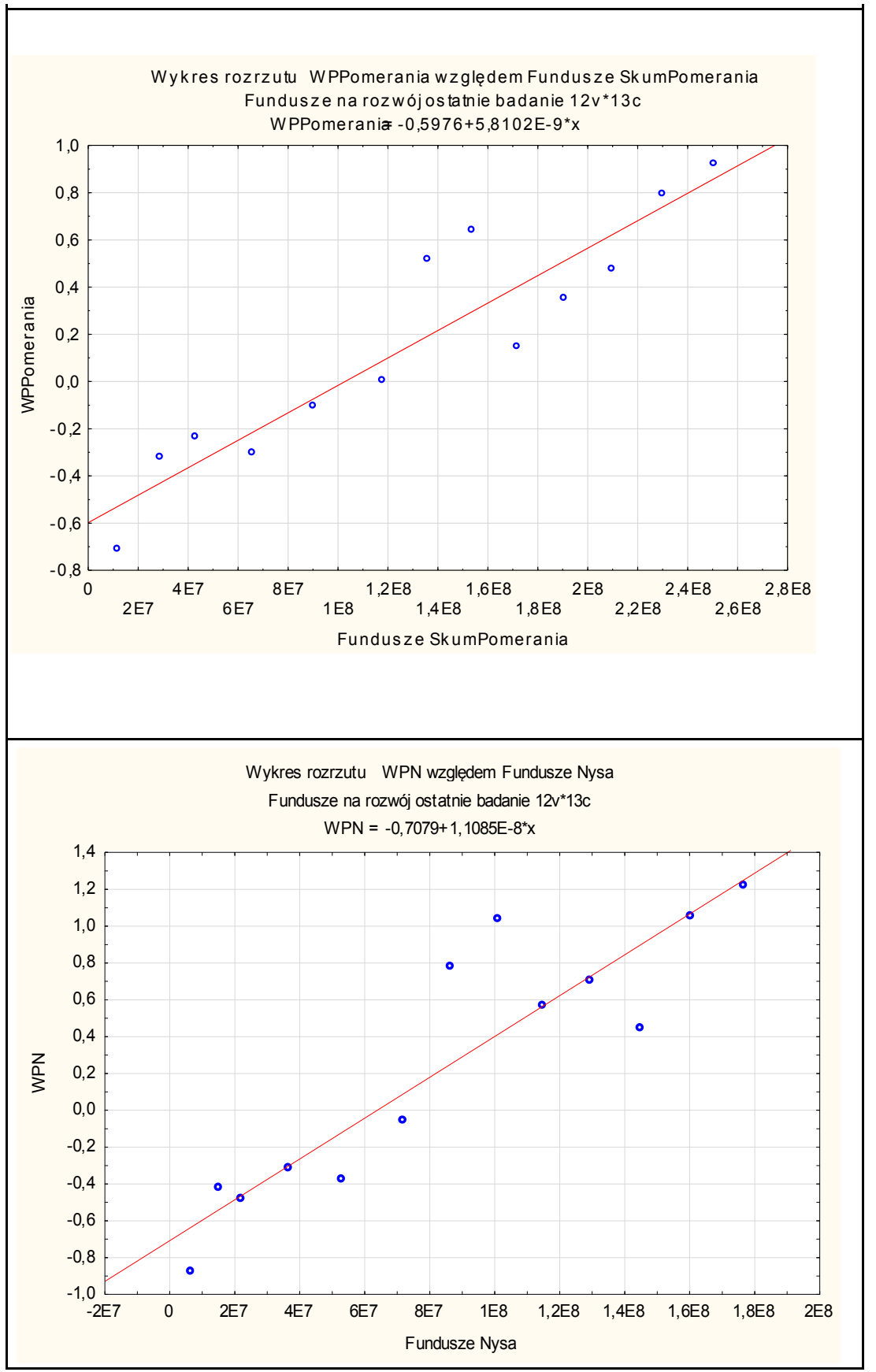

Wykres 7.7. Rozrzut pomiędzy wielkością funduszy UE a zrównoważonym rozwojem euroregionów

Źródło: obliczenia własne. 
Zgodnie z przedstawioną statystyczną analizą wpływu środków w ramach Europejskiej Współpracy Terytorialnej na zrównoważony rozwój euroregionów należy potwierdzić postawioną hipotezę o istotności wpływu środków unijnych na rozwój obszarów transgranicznych zachodniego pogranicza Polski.

\subsection{Uwagi końcowe}

Wskaźnik rozwoju zrównoważonego obliczony metodą Perkala pozwala zauważyć wyraźny wzrostowy trend rozwojowy we wszystkich analizowanych euroregionach. Wyznaczona prognoza dla lat 2015-2020 pozwala ocenić, że w euroregionach zachodniego pogranicza Polski ta tendencja zostanie również utrzymana. Jednocześnie podstawą rozwoju euroregionów są działania podejmowane w sferze gospodarczej i społecznej. Znamienitą rolę w rozwoju obszarów transgranicznych odgrywają transfery środków unijnych przekazywanych w ramach Europejskiej Współpracy Terytorialnej. Świadectwem istotnego wpływu funduszy unijnych na rozwój obszarów peryferyjnych są materialne i niematerialne efekty realizacji unijnej polityki regionalnej oraz przeprowadzona statystyczna analiza pozwalająca na pozytywną ocenę realizacji programów unijnych realizowanych w euroregionach. 



\section{Zakończenie}

Problematyka zrównoważonego rozwoju obszarów sfromalizowanej współpracy transgranicznej stanowi niezwykle interesujący problem badawczy. Współpraca euroregionalna jest jednym z podstawowych elementów strategii integracji i rozwoju peryferyjnych obszarów transgraniczych Unii Europejskiej. Szeroki wachlarz podejmowanych działań, obejmujący współpracę gospodarczą, społeczną i w ochronie środowiska doskonale wpisuje się w działania na rzecz zrównoważonego rozwoju. Unia Europejska uznaje euroregiony za jedną $\mathrm{z}$ formuł polityki regionalnej, a ich funkcjonowanie ma służyć uzyskiwaniu korzyści w wyniku kolektywnego działania ponad granicami państwowymi. Zrównoważony rozwój euroregionów uwarunkowany jest przez wykorzystanie ich wewnętrznego potencjału oraz transfer środków pieniężnych z Unii Europejskiej do regionów peryferyjnych.

Realizacja koncepcji zrównoważonego i trwałego rozwoju na poziomie regionalnym jest konsekwencją wzrostu roli i znaczenia regionów w Unii Europejskiej. Spowodowane jest to zwiększeniem świadomości regionalnej, zmianą reguł i zależności ekonomicznych oraz coraz większym znaczeniem struktur terytorialnych dla rozwoju krajów i ugrupowań integracyjnych. Świadomość regionalna i poczucie przynależności do lokalnej społeczności niosą za sobą konieczność efektywnego zarządzania swoim obszarem. U podstaw wzrostu roli regionów w Unii Europejskiej leży przekonanie o tym, że regiony skuteczniej adoptują się do zmieniających się warunków społeczno-gospodarczych, a przy tym działają efektywniej niż całe państwa. Pozycja regionów w Unii Europejskiej jest dodatkowo wzmacniana przez postępujące procesy integracji gospodarek i wdrażanie zasady subsydiarności. Regiony zaczynają odgrywać rolę pierwszoplanowych aktorów, a debaty na ich temat koncentrują się na zwiększeniu ich autonomii i uprawnień.

Narzędziem wykorzystywanym przez Unię Europejską na rzecz pomocy regionom słabiej rozwiniętym jest polityka regionalna. Jej ewolucja w ostatnich latach zorientowana jest na jak najbardziej efektywne wykorzystanie środków finansowych, czego przejawem jest wprowadzenie nowych, prostszych procedur oraz położenie nacisku na planowanie rozwoju regionalnego uwzględniające potencjał 
innowacyjny regionów. Dlatego konieczne jest zaangażowanie instytucji i podmiotów regionalnych oraz społeczności lokalnych w realizację jej założeń. Kierunek rozwoju polityki regionalnej Unii Europejskiej w okresie programowania 2014-2020 wyraźnie wskazuje na coraz większe znaczenie czynników strukturalnych wpływających na zwiększenie konkurencyjności. Finansowanie z funduszy ukierunkowane jest na wsparcie badań i rozwoju, wdrażanie nowych rozwiązań technologicznych czy inwestowanie w zasoby ludzkie.

Euroregiony są zinstytucjonalizowaną formą współpracy transgranicznej. Nazwa euroregion może oznaczać zarówno wyodrębniony region europejski położony na pograniczu sąsiadujących ze sobą państw, jak i organizację utworzoną przez strony umowy euroregionalnej w celu koordynacji i wsparcia współpracy na obszarze pogranicza. Istotne jest, aby umowa ta miała charakter dobrowolny oraz została zaakceptowana przez Unię Europejską, która wykorzystując instrumenty polityki regionalnej, może wspierać finansowo jej działalność. Szeroki wachlarz działań euroregionalnych ukierunkowany jest na wymianę doświadczeń i informacji, poprawę warunków życia lokalnej społeczności, rozwój gospodarki, handlu, turystyki i infrastruktury technicznej. Euroregiony odgrywają ważną rolę w aktywizacji pogranicza, prowadząc do polepszenia sytuacji gospodarczej i poprawy ochrony środowiska naturalnego. Przeprowadzona analiza cech euroregionów na zachodniej granicy Polski wskazuje, że dzięki podejmowanym w nich, skoordynowanym działaniom następuje poprawa podstawowych wskaźników ekonomicznych, społecznych i wzrasta świadomość ekologiczna mieszkańców.

Wielopłaszczyznowość współpracy euroregionalnej daje nowe szanse dla tworzenia przedsiębiorstw i rozwoju przedsiębiorczości lokalnej w regionach peryferyjnych. Euroregiony są podstawowym ogniwem strategii tworzenia małych i średnich przedsiębiorstw oraz kreowania sieci współpracy pomiędzy nimi. Zadaniem euroregionów jest podejmowanie takich działań, które będą sprzyjały i ułatwiały przedsiębiorcom funkcjonowanie oraz pobudzały lokalną społeczność do podejmowania inicjatyw gospodarczych. W odniesieniu do doświadczeń euroregionów można zauważyć, że ich niewątpliwym walorem jest zasobność endogeniczna, natomiast problemy związane z peryferyjnym położeniem udało się ograniczyć. Współpraca euroregionalna poprzez mobilizację potencjału regionów transgranicznych oraz stosowanie wypracowanych mechanizmów kooperacji pomiędzy władzami regionalnymi i samorządowymi a ośrodkami naukowo-badawczymi, uczelniami wyższymi, przedsiębiorstwami i instytucjami odgrywa istotną rolę $\mathrm{w}$ procesie kształtowania się konkurencyjnej i innowacyjnej gospodarki opartej na wiedzy. Jedną z możliwości uzyskania przewagi konkurencyjnej w polityce regionalnej jest budowa klastrów transgranicznych. Tworzenie klastrów zwiększa zdolność konkurencyjną i prowadzi do szybszego rozwoju regionów peryferyjnych. Euroregiony na drodze ku osiągnięciu smart specialization powinny korzystać z możliwości, jakie dają im grona. Słuszne jest twierdzenie, że euroregionalizacja 
poprzez tworzenie więzi pomiędzy lokalnymi społecznościami stanowi podstawowy czynnik rozwoju klastrów w regionach peryferyjnych.

W euroregionach zachodniego pogranicza Polski w całym analizowanym okresie miał miejsce rozwój. Wskazują na to wyznaczone wskaźniki analityczne oraz syntetyczny wskaźnik rozwoju Perkala. Miernik ten wskazuje na stosunkowo niski poziom zrównoważonego rozwoju w badanych obszarach sformalizowanej współpracy transgranicznej. Najwyższy jego poziom w 2014 r. odnotowano w Euroregionie Neisse-Nisa-Nysa $(1,38)$ oraz w Euroregionie Pomerania $(1,05)$. Niski poziom rozwoju odnotowano zaś w Euroregionie Pro Europa Viadrina $(0,49)$ oraz w Euroregionie Sprewa-Nysa-Bóbr $(0,88)$. Na podkreślenie zasługuje fakt, że w analizowanym czasie nastąpił znaczący postęp w euroregionach. Wskaźnik postępu wyznaczony jako różnica we wskaźniku Perkala pomiędzy okresem końcowym (2014 r.) a okresem bazowym (2000 r) wskazuje, że największy postęp odnotowano w Euroregionie Pomerania $(2,2)$ oraz w Euroregionie Neisse-Nisa-Nysa $(2,17)$. Najniższy zaś w Euroregionie Pro Europa Viadrina na poziomie 0,41. Prognoza wskaźnika Perkala również daje podstawy dla pozytywnej oceny dalszego rozwoju euroregionów i słuszności podejmowanych w nich działań.

Zrównoważony rozwój badanych euroregionów uwarunkowany jest przez szereg czynników o charakterze egzogenicznym i endogenicznym. Niewątpliwie jednak sąsiedztwo z Niemcami oraz transfery środków w ramach polityki regionalnej UE powodują, że rozwój ten nabiera większego tempa i pozwala zmniejszać negatywne aspekty przygranicznego położenia. Instrumenty finansowe unijnej polityki regionalnej istotnie przyczyniają się do poprawy jakości i warunków życia lokalnych społeczności. Świadectwem dla takiego stwierdzenia są materialne i niematerialne projekty zrealizowane w euroregionach ze środków unijnych, które nie doszłyby do skutku bez zaangażowania funduszy europejskich.

Hipotezę główną dysertacji potwierdza przeprowadzana analiza statystyczna. Wyznaczona linia trendu dla zależności pomiędzy wskaźnikiem postępu w euroregionach zachodniego pogranicza Polski a wartością środków finansowych jest rosnąca, co pozwala na pozytywną ocenę wpływu unijnej polityki regionalnej na zrównoważony rozwój euroregionów. Należy jednak zauważyć, że jedynie Euroregion Neisse-Nisa-Nysa w sposób efektywny wykorzystuje środki unijnej polityki regionalnej. Pozostałe euroregiony znajdują się nieznacznie poniżej wyznaczonej linii trendu. Należy odnotować, że największe dofinansowanie z Unii Europejskiej uzyskał Euroregion Pomerania, a najmniejsze Euroregion Pro Europa Viadrina. Również przeprowadzona statystyczna analiza korelacji i regresji pomiędzy skumulowanymi wartościami przepływów pieniężnych z Unii Europejskiej a zrównoważonym rozwojem euroregionów wskazuje na wysoki poziom statystycznej zależności pomiędzy analizowanymi zmiennymi.

Odpowiadając na postawione we wstępie rozprawy pytania badawcze, należy stwierdzić, że zasadność realizacji koncepcji zrównoważonego rozwoju na poziomie regionalnym związana jest ze wzrostem roli regionów w Unii Europejskiej. 
Zmniejszanie dysproporcji $\mathrm{w}$ poziomie rozwoju regionów jest podstawowym celem unijnej polityki regionalnej, której obecny model wykształcił się na podstawie wieloletnich doświadczeń. Cele i instrumenty polityki regionalnej są tak formułowane, aby w sposób jak najbardziej efektywny, a zarazem dopasowany do bieżącej sytuacji społeczno-gospodarczej, przyczyniać się do rozwoju regionów. Euroregiony dzięki odpowiedniej strukturze prawno-organizacyjnej oraz roli w polityce regionalnej Unii Europejskiej przyczyniają się do aktywizacji terenów przygranicznych oraz odgrywają zasadniczą rolę w realizacji koncepcji zrównoważonego rozwoju obszarów peryferyjnych. Współpraca euroregionalna poprzez podejmowanie działań zachęcających i wspierających lokalnych przedsiębiorców sprzyja rozwojowi przedsiębiorstw $\mathrm{w}$ regionach transgraniczych. 


\section{Bibliografia}

\section{Monografie oraz artykuły naukowe}

Amin A., An Institutionalist Perspective on Regional Economic Development, „International Journal of Urban and Regional Research", vol. 23, no 2/1999.

Balak-Hryńkiewicz M., Europa regionów a zasada subsydiarności w Unii Europejskiej, „Świętokrzyskie Centrum Edukacji na Odległość", nr 1/2007.

Banaszak S., Statystyka, [w:] M. Zdulski (red.), 20 lat współpracy transgranicznej w Euroregionie Neisse-Nisa-Nysa, Wydawnictwo Ad Rem, Jelenia Góra 2011.

Benio M., Bober J., Hausner J., Kołdras S., Kudłacz T., Mamica Ł., Programowanie rozwoju regionalnego, Poradnik dla samorzq̨dów województwa, Małopolska Szkoła Administracji Publicznej Akademii Ekonomicznej w Krakowie, Kraków 1999.

Borys T., Jak budować program ekorozwoju w regionie. Agenda 21, t. II "Zielony Region", Wydawnictwo Fundacja Karkonoska, Warszawa-Jelenia Góra 1998.

Borys T., Problemy statystyki transgranicznej, ,Wiadomości Statystyczne”, nr 9/1999.

Borys T., W stronę zrównoważonego rozwoju polskich gmin i powiatów, [w:] T. Borys (red.), Zarzqdzanie zrównoważonym rozwojem. Agenda 21 w Polsce - 10 lat po Rio, Wydawnictwo Ekonomia i Środowisko, Białystok 2003.

Bruszewska E., Państwo we współpracy transgranicznej, [w:] M. Perkowski (red.), Współpraca transgraniczna. Aspekty prawno-ekonomiczne, Fundacja Prawo i Partnerstwo, Białystok 2010.

Calster G., Berwin S.J., Deketelaere K., The Intergovernmental Conference and Greening the EU Treaty, „European Environmental Law Review”, no 1/1998.

Chojnicki Z., Czyż T., Zróżnicowanie przestrzenne poziomu życia ludności, „Biuletyn KPZK PAN, nr 153/1991.

Chojnicki Z., Region w ujęciu geograficzno-systemowym, [w:] T. Czyż (red.), Podstawy regionalizacji geograficznej, Bogucki Wydawnictwo Naukowe, Poznań 1996.

Chojnicki Z., Problematyka metodologiczna studiów regionalnych, „Studia Regionalne i Lokalne”, $\mathrm{nr} 4(18) / 2004$.

Chorąży K., Zagadnienia ustroju lokalnego Francji, Wydawnictwo Verba, Lublin 1998.

Churski P., Czynniki rozwoju regionalnego w świetle koncepcji teoretycznych, „Zeszyty Naukowe Wyższej Szkoły Humanistyczno-Ekonomicznej we Włocławku. Nauki ekonomiczne", t. XIX, z. 3/2005.

Cichocki M., Regionalizacja versus integracja. Teorie rozwoju regionalnego a polityka bezpieczeń-

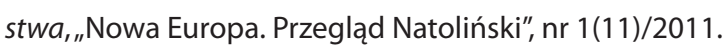


Ciepielewska M., Mucha-Leszko B., Integracja Europejska. Droga do unii ekonomicznej i monetarnej, Wydawnictwo Uniwersytetu Marii Curie-Skłodowskiej, Lublin 1994.

Ciok S., Bariery i ograniczenia współpracy transgranicznej, [w:] J. Kitowski, Czynniki bariery regionalnej współpracy transgranicznej - próba syntezy, Wydawnictwo UMCS, Lublin 1998.

Cyrek M., Procesy upodabniania się struktur gospodarczych Polski i wybranych krajów Unii Europejskiej, „Zeszyty Naukowe Uniwersytetu Rzeszowskiego”, nr 8/2006.

Czachór Z., Słowniczek europejski, Przedstawicielstwo Komisji Europejskiej w Polsce, Warszawa 1996. Czarny R.M., Regionalizm w stosunkach międzynarodowych 1945-75, Wydawnictwo WSP, Kielce 1986.

Czerniecka M., Dostęp do finansowania dla innowacyjnych mikro, małych i średnich przedsiębiorstw w Regionie Morza Battyckiego. Forum Euroregion Pomerania Przedsiębiorczością stoi - 60, Polsko-Niemieckie Forum Przedsiębiorców, Szczecin 2011.

Czubocha K., Finansowanie polityki regionalnej Unii Europejskiej a wyzwania XXI wieku, ee-Finanse. Kwartalnik Finansowy", nr 3/2006.

Czykier-Wierzba D., Finansowanie polityki regionalnej w Unii Europejskiej. Euro od A do Z, Narodowy Bank Polski, Warszawa 2004.

Dammeyer M., Rozwój regionów w Europie, „'Studia Europejskie”, nr 2/1999.

Damrosz J., Region i regionalizm (Studium interdyscyplinarne), Instytut Kultury, Warszawa 1987.

Danielewski F., Regionalizm: pojęcie, ewolucja, [w:] R. Fedan (red.), Przedsiębiorstwo i region, Przedsiębiorstwo i region w procesie transformacji, Uniwersytet Rzeszowski, Rzeszów 2006.

Dąbrowski A., Globalizacja a regionalizm, „Prace Naukowe Uniwersytetu Ekonomicznego we Wrocławiu", nr 244/2012.

Dołzbłasz S., Raczyk A., Współpraca transgraniczna w Polsce po akcesji do UE, Wydawnictwo Wolters Kluwer Polska SA, Warszawa 2010.

Domański R., Geografia ekonomiczna, PWN, Warszawa 1982.

Drabiński A., Nieznański P., Odrzańska Droga Wodna a środowisko przyrodnicze. Studia nad rozwojem Dolnego Śląska, Urząd Marszałkowski Województwa Dolnośląskiego, Wrocław 2010.

Dumała H., Czy istnieje model „polskiego" euroregionu?, [w:] W. Malendowski, M. Szczepaniak (red.), Euroregiony: mosty do Europy bez granic, Wydawnictwo Elipsa, Warszawa 2000.

Dziembała M., Wspieranie innowacyjności gospodarek regionalnych w świetle Strategii Europa 2020, Prace Naukowe Uniwersytet Ekonomiczny w Katowicach, Katowice 2013.

Dziemianowicz W., Kapitał zagraniczny a rozwój regionalny i lokalny w Polsce, "Studia Regionalne i Lokalne", nr 21(54)/1997.

Ercman S., Das Europäische Rahmenübereinkommen über die grenzüberschreitende Zusammenarbeit zwischen Gebietskörperschaften, [w:] M., Bothe, M. Prieur, G. Ress (red.), Rechtsfragen grenzüberschreitender Umweltbelastungen, Fachtagung/Saarbrucken, Berlin 1984.

Fabish I., Równość szans, [w:] M. Zdulski, 20 lat współpracy transgranicznej w Euroregionie Neisse -Nysa-Nisa, Wydawnictwo Ad Rem, Jelenia Góra 2011.

Fic M., Elementy metodologii obszarów przygranicznych, „Wiadomości Statystyczne”, nr 11/1996.

Fic M., Ogrodowicz S., Badania społeczno-gospodarcze obszarów przygranicznych, „Wiadomości Statystyczne", nr 6/1996.

Florida R., Toward the learning region, „Futures”, vol. 27, no 5/1995. 
Fujita, M., Mori, T., Frontiers of the New Economic Geography, "Institute of Developing Economies. Discussion Paper", no 27/2005.

Furmankiewicz M., Polskie samorządy gminne w organizacjach międzynarodowych, Instytut Geografii i Rozwoju Regionalnego, Uniwersytet Wrocławski, Wrocław 2004.

Gajda J.B., Ekonometria, Wydawnictwo C.H. Beck, Warszawa 2004.

Gałęski M., 20 lat ochrony przed zagrożeniami. Przeciwdziałanie i usuwanie skutków katastrof i klęsk na styku granic Niemiec, Czech i Polski, [w:] M. Zdulski, 20 lat współpracy transgranicznej w Euroregionie Neisse-Nysa-Nisa, Wydawnictwo Ad Rem, Jelenia Góra 2011.

Gawlikowska-Hueckel K., Zielińska-Głębocka A., Integracja europejska. Od jednolitego rynku do unii walutowej, Wydawnictwo C.H. Beck, Warszawa 2004.

Gellrich R., Edukacja: stan obecny i perspektywy, [w:] M. Zdulski, 20 lat współpracy transgranicznej w Euroregionie Neisse-Nysa-Nisa, Wydawnictwo Ad Rem, Jelenia Góra 2011.

Gierczycka J., konomiczne i społeczne problemy realizacji zrównoważonego rozwoju (w aspekcie Strategii Lizbońskiej), [w:] Uwarunkowania i mechanizmy zrównoważonego rozwoju. Materiały VI Międzynarodowej Konferencji Naukowej, Wydawictwo Wyższej Szkoły Ekonomicznej w Białymstoku, Białystok 2007.

Gierczyńska J., Ewolucja wspólnych polityk Unii Europejskiej w kierunku zrównoważonego rozwoju, [w:] D. Kiełczewski, B. Dobrzańska (red.), Ekologiczne problemy zrównoważonego rozwoju, Wydawnictwo Wyższej Szkoły Ekonomicznej w Białymstoku, Białystok 2009.

Godłów-Legiędź J., Transformacja ustrojowa z perspektywy nowej ekonomii instytucjonalnej, „Ekonomista", nr 2/2005.

Golejewska A., Kapitał ludzki, innowacje i instytucje a konkurencyjność regionów Europy Środkowej Wschodniej, „"Centrum Europejskie Natolin", z. 49/2012.

Golka M., Pogranicza - transgraniczność - transkulturowość, [w:] L. Gołdyka (red.), Transgraniczność w perspektywie socjologicznej - kontynuacje, Lubuskie Towarzystwo Naukowe, Zielona Góra 1999.

Gorynia, M., Jankowska, B., Koncepcja klastrów jako sposób regulacji zachowań podmiotów gospodarczych, „Ekonomista”, nr 3/2007.

Gorzelak G., Reforma ekonomiczna w Polsce na tle rozwoju regionalnego, "Ekonomista”, nr 1/1989.

Greta M., Endogeniczność w rozwoju regionów/euroregionów w aspekcie europejskich wyzwań smart specialistaion, „,Optimum. Studia Ekonomiczne”, nr 1(67)/2014.

Greta M., Euroregionalizacja i jej wpływ na lokalny rynek pracy, [w:] D. Kopycińska (red.), Działania ekonomiczne podmiotów rynkowych, Katedra Mikroekonomii Uniwersytetu Szczecińskiego, Szczecin 2007.

Greta M., Euroregiony a integracja europejska. Wnioski dla Polski, Wydawnictwo Uniwersytetu Łódzkiego, Łódź 2003.

Greta M., Euroregiony polskie w procesie integracji europejskiej oraz w przezwyciężaniu peryferyjności i dysproporcji regionalnych, Wydawnictwo Uniwersytetu Łódzkiego, Łódź 2013.

Greta M., Kostrzewa-Zielińska T., Od współpracy transgranicznej do euro regionalizacji i uruchamiania przedsiębiorczości lokalnej, „Ekonomia i Zarządzanie. Zeszyty Naukowe Politechniki Białostockiej", z. 12/2008. 
Greta M., Lewandowski K., Euroregion Bałtyk wobec wyzwań aktywujących pogranicze „ „Ostrołęckie Towarzystwo Naukowe im. Adama Chętnika. Zeszyty Naukowe", nr 20/2006.

Greta M., Lewandowski K., Euroregion jako instrument realizacji spójności społeczno-ekonomicznej iStrategii Lizbońskiej „„Czasopisma Uniwersytetu Rzeszowskiego”, z. 12/2008.

Grosse H., Euroregion Neisse-Nysa-Nisa na drodze do wspólnej przestrzeni gospodarczej, [w:] M. Zdulski (red.), 20 lat współpracy transgranicznej w Euroregionie Neisse-Nysa-Nisa, Wydawnictwo Ad Rem, Jelenia Góra 2011.

Grosse T.G., Wybrane koncepcje teoretyczne i doświadczenia praktyczne dotyczq̨ce rozwoju regionów peryferyjnych, „Studia Regionalne i Lokalne”, nr 1(27)/2007.

Grossman G., Helpman E., Innovation and Growth in the Global Economy, MIT Press, Cambridge 1991.

Grzela J., Region, regionalizm, regionalizacja - wybrane aspekty teoretyczne, „Studia i Materiały. Miscellanea Oeconomicae", nr 1(15)/2011.

Grzelak G., Ekorozwój w Euroregionie "Sprewa-Nysa-Bóbr", Projekt Pilotażowy, Gubin 2000.

Hajduk S., Szlaki turystyczne jako element integracji regionów transgranicznych, „CZłowiek i Środowisko", nr 31(3-4)/2007.

Haliżak E., Regionalizm w stosunkach międzynarodowych, [w:] E. Haliżak, R. Kuźniar (red.), Stosunki międzynarodowe. Geneza, struktura, dynamika, Wydawnictwo Uniwersytetu Warszawskiego, Warszawa 2006.

Hołuj A., Korecki D., Uwarunkowania rozwoju regionalnego w Polsce, „Zeszyty Naukowe Wyższej Szkoły Ekonomicznej w Bochni", nr 7/2008.

Huber P., Regional labour market developments in transition, "The European Journal of Comparative Economics", no 4(2)/2007.

Jabłońska A., Hryniewiecka W., Projekt Europejski jako forma współpracy transgranicznej, [w:] M. Perkowski (red.), Współpraca transgraniczna. Aspekty prawno-ekonomiczne, Fundacja Prawo i Partnerstwo, Białystok 2010.

Jankowska A., Fundusze Unii Europejskiej w okresie programowania 2007-2013, Polska Agencja Rozwoju Przedsiębiorczości, Warszawa 2005.

Jasiński A.H., Innowacje i transfer techniki w procesie transformacji, Wydawnictwo Difin, Warszawa 2006.

Jasiński L.J., Globalna pozycja Unii Europejskiej w dłuższej perspektywie, „Studia Europejskie. Centrum Europejskie Uniwersytetu Warszawskiego", nr 4(72)/2014.

Jasiński L.J., Uwagi na temat Strategii „Europa 2020”, Aktualna prognoza makroekonomiczna INE-PAN, Konwersatorium o „Przyszłości Społecznej i Gospodarczej Polski”, 13 maja 2010 r.

Jastrzębska W., Rola euroregionów i współpracy transgranicznej w procesie integracji europejskiej, Wydawnictwo Uniwersytetu Rzeszowskiego, Rzeszów 2008.

Jurkowska B., Unijne programy wsparcia współpracy transgranicznej w latach 2007-2013 w państwach członkowskich i sąsiadujących z Uniq̨ Europejskq , Studia Lubuskie", t. VII/2011.

Juszczyk S., Jasionek M., Źródła i bariery działalności innowacyjnej w przedsiębiorstwach branży spożywczej województwa podlaskiego, „Stowarzyszenie Ekonomistów Rolnictwa i Agrobiznesu. Roczniki Naukowe", t. XIII, z. 2/2011. 
Juszczyk S., Korporatyzacja innowacji jako współczesna bariera rozwoju nauk ekonomicznych, „Rocznik Nauk Rolniczych. Seria G. Ekonomika Rolnictwa", t. 97, z. 2/2010.

Karmowska G., Badanie i pomiar rozwoju regionalnego na przykładzie województwa zachodniopomorskiego, ,"Roczniki Nauk Rolniczych. Seria G", t. 98, z. 2/2011.

Kawałko B., Granica wschodnia jako czynnik ożywienia i rozwoju społeczno-ekonomicznego regionów przygranicznych. Synteza, Ekspertyza dla Ministerstwa Rozwoju Regionalnego, Warszawa 2008.

Kawałko B., Stymulowanie rozwoju w regionie transgranicznym, "Gospodarka Narodowa", nr 6/1997.

Kawałko B., Wybrane problemy polsko-ukraińskiej współpracy transgranicznej „,Barometr Regionalny. Analizy i prognozy", nr 2(24)/2011.

Keating M., Is there a regional level of government in Europe?, [w:] P. Le Gales, Ch. Lequense (red.), Regions in Europe, London-New York 1998.

Kiełczewski D., Rozwój zrównoważony w skali regionalnej. Środowisko przyrodnicze - czynnik czy bariera rozwoju?, Forum Inicjatyw Wspólnotowych, Białystok 2009.

Klassen L., Area, Economic and Social Redevelopment, Paris 1965, [za:] Z. Szymla, Podstawy badań nad rozwojem regionalnym, „Zeszyty Naukowe Wyższej Szkoły Ekonomicznej w Bochni”, nr 3/2005.

Klasik A., Kuźnik F., Konkurencyjny rozwój regionów w Europie, [w:] Z. Szymla (red.), Konkurencyjność miast i regionów, Wydawnictwo Akademii Ekonomicznej w Krakowie, Kraków 2001.

Kociszewski A., Regionalizm mazowiecki, Wydawnictwo Triada, Warszawa 1993.

Köning F., Południowy Tyrol - trudna droga do pojednania w duchu europejskim, [w:] M. Zalewska-Zemła, Euroregiony, Wydawnictwo Wokół Nas, Gliwice 1993.

Konopacki S., Polska pięć lat w Unii Europejskiej, Wydawnictwo Ibidem, Łódź 2009.

Kopaliński W., Słownik wyrazów obcych i zwrotów obcojęzycznych, Wydawnictwo Wiedzy Powszechnej, Warszawa 1989.

Korczak J., Ewolucja form współdziałania jednostek samorządu terytorialnego na forum międzynarodowym, [w:] J. Sługocki (red.), Samorząd terytorialny w Polsce i w Europie. Doświadczenia i dylematy dalszego rozwoju, Wydawnictwo Kujawsko-Pomorskiej Szkoły Wyższej, Bydgoszcz 2009.

Kosiedowski W., Słowińska B., Położenie przygraniczne jako szansa rozwoju północno-wschodniej Polski w warunkach integracji europejskiej (w świetle badań ankietowych), [w:] Z. Strzelecki (red.), Samorzad terytorialny w Polsce. Szanse rozwoju regionalnego i lokalnego w warunkach Unii Europejskiej, Wydawnictwo SGH, Warszawa 2008.

Kosmalski R., Konwergencja i nierówności regionalne w Polsce w świetle metody DEA (rozprawa doktorska), Uniwersytet Ekonomiczny w Poznaniu Wydział Informatyki i Gospodarki Elektronicznej, Poznań 2011.

Kozak M., Pyszkowski A., Szewczyk R., Słownik rozwoju regionalnego, PARR, Warszawa 2001.

Krakowiak-Bal A., Potencjał gospodarczy gmin przygranicznych Polski Południowej, ,Infrastruktura i Ekologia Terenów Wiejskich", nr 2(2)/2006.

Krok K., Smętkowski M., Polsko-ukraińska współpraca transgraniczna, [w:] G. Gorzelak, K. Krok (red.), Nowe granice Unii Europejskiej - współpraca czy wykluczenie?, Wydawnictwo Naukowe Scholar, Warszawa 2006. 
Krugman P.R., Obstfeld M., Ekonomia międzynarodowa. Teoria i polityka, t. 2, Wydawnictwo Naukowe PWN, Warszawa 2007.

Kudełko J., Uwarunkowania rozwoju regionalnego w świetle założeń europejskiej polityki spójności na lata 2014-2020, "Uniwersytet Ekonomiczny w Katowicach. Studia Ekonomiczne”, nr 166/2014.

Kukliński A., Gospodarka przestrzenna i studia regionalne. Problemy dyskusyjne, „Biuletyn KPZK PAN", nr 111/1980.

Kulesza E., Współpraca transgraniczna jako czynnik rozwoju lokalnego na przykładzie gmin polskiego pogranicza z Rosja, Toruń 2003.

Kulesza M., Transformacja ustroju administracyjnego Polski (1990-2000), "Studia luridica”, nr 38/2000.

Kulesza M., Zasada subsydiarności jako klucz do reform ustroju administracyjnego państw Europy Środkowej i Wschodniej (na przykładzie Polski), [w:] D. Milczarek (red.), Subsydiarność, Centrum Europejskie Uniwersytetu Warszawskiego, Warszawa 1998.

Kupiec T., Rola regionów w Europie w kontekście polityki spójności UE, Wydział Rozwoju Regionalnego Urzędu Marszałkowskiego Województwa Śląskiego, Katowice 2009.

Kusiak-Winter R., Współpraca transgraniczna gmin Polski i Niemiec - studium administracyjnoprawne „,Prace Naukowe Wydziału Prawa, Administracji i Ekonomii Uniwersytetu Wrocławskiego”, nr 11/2011.

Kwaśniewski K., Słownik etnologiczny. Terminy ogólne, Państwowe Wydawnictwo Naukowe, Warszawa-Poznań 1987.

Kwilecki A., Region i badania regionalne w perspektywie socjologii, „Ruch Prawniczy, Ekonomiczny i Socjologiczny", z. 2/1992.

Latocha T., Bezpośrednie inwestycje zagraniczne w Unii Europejskiej w świetle teorii rozwoju regionalnego i teorii lokalizacji, „Centrum Europejskie Uniwersytetu Warszawskiego. Studia Europejskie", nr 2/2005.

Lipowicz I., Europejski standard samorządu terytorialnego a ustawodawstwo polskie, "Samorząd Terytorialny", nr 11-12/1991.

Lis M., Regiony jako trzeci poziom współpracy europejskiej, [w:] M. Maciejewski (red.), Społeczeństwo w przełomie. Polska, Niemcy i Unia Europejska, Wydawnictwo Uniwersytetu Wrocławskiego, Wrocław 1999.

Lucas R.E., On the Mechanics of Economic Development, "Journal of Monetary Economics", no $1(22) / 1988$.

Ładysz J., Polityka strukturalna Polski i Unii Europejskiej, Wydawnictwo Naukowe PWN, Warszawa 2008.

Łapińska-Sobczak N., Opisowe modele ekonometryczne. Elementy teorii. Przykłady i zadania, Wydawnictwo Uniwersytetu Łódzkiego, Łódź 2001.

Łodziński S., Cele i zasady polityki regionalnej w Unii Europejskiej, „Kancelaria Sejmu. Biuro Studiów i Ekspertyz", nr 483/1997.

Łuków E., Integracja gospodarcza i walutowa w Unii Europejskiej, XVIII Ogólnopolska Szkoła Europejska, Przemyśl 2001.

Machowski J., Ochrona środowiska. Prawo i zrównoważony rozwój. (Stan prawny na dzień 1 stycznia 2003 r.), Wydawnictwo Akademickie „Żak", Warszawa 2003. 
Malarski S., Euroregiony obszarów przygranicznych Polski oraz podstawy prawno-traktatowe stosunków Polski z państwami sq̨siadującymi, [w:] M. Perkowski (red.), Współpraca transgraniczna. Aspekty prawno-ekonomiczne, Fundacja Prawo i Partnerstwo, Białystok 2010.

Malendowski W., Ratajczak M., Euroregiony - pierwszy krok do integracji europejskiej, Wydawnictwo Alta 2, Wrocław 1998.

Malendowski W., Szczepaniak M., Rola euroregionów w procesie integracji europejskiej, [w:] W. Malendowski, M. Szczepaniak (red.), Euroregiony - mosty bez granic, Wydawnictwo Dom Wydawniczy Elipsa, Warszawa 2000.

Małecka E. (red.), Euroregiony na granicach Polski 2003, Urząd Statystyczny, Wrocław 2004.

Martin, R., Institutional Approaches in Economic Geography, [w:] E. Sheperd, T.J. Barnes (red.), A Companion in Economic Geography, Blackwell, Oxford 2000.

Matusiewicz Z., Lokalny wymiar integracji europejskiej, [w:] M. Barański, M. Stolarczyk (red.), Władze lokalne i regionalne $w$ warunkach globalizacji, Wydawnictwo Uniwersytetu Śląskiego, Katowice 2003.

Mazur-Wierzbicka, E., Koncepcja zrównoważonego rozwoju w praktyce społeczno-gospodarczej Unii Europejskiej, „Ekonomia", nr 4(21)/2012.

Mączka L., Gospodarka globalna u progu XXI wieku, Wydawnictwo Akademii Ekonomicznej w Krakowie, Kraków 2003.

Mączkowski K., Przez Viadrinę do Europy „,E-czytelnia”, nr 3(150)/2004 .

McLean I., The Concise Oxford Dictionary of Politics, Oxford University Press, Oxford-New York 1996.

Mempel-Śnieżyk A., Koncepcje rozwoju regionalnego ze Szczególnym uwzględnieniem klastrów i inteligentnych specjalizacji, „Biblioteka Regionalisty”, nr 13/2013.

Michałek K., Master B., Jak fundusze europejskie zmieniają Polskę. Scenariusz zajęć, Fundacja Viribus Unitis, Katowice 2009.

Michałowska G., Mały słownik stosunków międzynarodowych, Wydawnictwo Szkolne i Pedagogiczne, Warszawa 1996.

Mierosławska A., Czynniki aktywizujące i hamujące rozwój współpracy transgranicznej, „,Samorząd Terytorialny", nr 3/2004.

Mierosławska A., Euroregiony na granicach Polski, Wydawnictwo Instytutu Ekonomiki Rolnictwa i Gospodarki Żywnościowej, Warszawa 1999.

Mikuła-Baczek E., Czynniki ograniczajqce i aktywizujące współpracę transgraniczną Polski i Ukrainy, [w:] M.G. Woźniak (red.), Spójność społeczno-ekonomiczna a modernizacja regionów transgranicznych, Wydawnictwo Uniwersytetu Rzeszowskiego, Rzeszów 2008.

Mindur M., Polityka współpracy transgranicznej na polskich pograniczach wschodnich, północnych i południowych a przyspieszenie procesów integracyjnych Polski z państwami Unii Europejskiej, „Polityka Gospodarcza”, nr 5-6/2001-2002.

Misiak W., Siemiński J.L., Koncepcje rozwoju regionalnego Polski w świetle doświadczeń integracyjnych Europy ',"Studia Europejskie", nr 3/2001.

Misiuda-Rewera W., Włochy. Republika autonomii, Wydawnictwo UMCS, Lublin 2005.

Mogiła Z., Zaleski J., Zathey M., Wykorzystanie przygranicznego położenia terenów znajdujących się w zachodniej części Polski dla rozwoju społeczno-gospodarczego, Ekspertyza przygotowana 
na zamówienie Ministerstwa Rozwoju Regionalnego w ramach prac nad Strategią Rozwoju Polski Zachodniej, Wrocław 2011.

Myrdal G., Economic Theory and Underdeveloped Regions, Duckworth, London 1957.

Naruszewicz S., Polityka spójności Unii Europejskiej. Wybrane zagadnienia, Wydawnictwo Difin, Warszawa 2004.

Niewiadomski Z., Samorząd terytorialny, [w:] Z. Niewiadomski (red.), Prawo administracyjne, Wydawnictwo Uniwersytetu Kardynała Stefana Wyszyńskiego w Warszawie, Warszawa 2007. North D.C., Understanding Economic Change and Economic Growth, [w:] G.W. Kołodko (red.), Globalizacja, marginalizacja, rozwój, Wydawnictwo Wyższej Szkoły Przedsiębiorczości i Zarządzania im. Leona Koźmińskiego, Warszawa 2003.

Novotná Galuszková J., Kardaczyńska D., Siara M., Euroregion Silesia, Przekraczamy granice, Wydawnictwo i Agencja Informacyjna WAW Grzegorz Wawoczny, Racibórz 2009.

Nowak P., Nowy paradygmat rozwoju regionalnego na przykładzie wybranych regionów Europy zachodniej (rozprawa doktorska), Uniwersytet Ekonomiczny w Poznaniu, Poznań 2011.

Nye J.S., International Regionalism: Readings, Little, Brown \& Co., Boston 1968.

Obrębalski M., Społeczno-ekonomiczna charakterystyka pogranicza Polski, „Wiadomości Statystyczne", nr 10/1999.

Ogrodowicz S., Ruch i handel graniczny oraz ich skutki społeczne i ekonomiczne , Wiadomości Statystyczne", nr 11/1999.

Olechnicka A., Regiony peryferyjne w gospodarce informacyjnej, Wydawnictwo Naukowe Scholar, Warszawa 2004.

Osmańczyk E.J., Encyklopedia spraw międzynarodowych i ONZ, PWN, Warszawa 1974.

Otto J., Kostrzewa-Zielińska T., Greta M., Przedsiębiorczość w założeniach i realizacji Strategii lizbońskiej oraz w założeniach Strategii Europa 2020, „Zeszyty Naukowe Uniwersytetu Szczecińskiego. Ekonomia. Problemy Usług", nr 63/2011.

Otto J., Kostrzewa-Zielińska T., Greta M., Unijna polityka wsparcia sektora MSP elementem uwarunkowań międzynarodowej aktywności przedsiębiorstw, [w:] J. Witkor, A. Żbikowska (red.), Marketing międzynarodowy. Uwarunkowania i kierunki rozwoju, Wydawnictwo PWE, Warszawa 2010.

Pakulska T., Poniatowska-Jaksch M., Rozwój zrównoważony - „szeroka i wąska” interpretacja, stan wiedzy, Wydawnictwo Szkoły Głównej Handlowej, Warszawa 2009.

Palej A., Wzrost znaczenia regionów i ich roli w Unii Europejskiej na przykładzie najnowszych propozycji i postulatów w wymiarze politycznym i ekonomicznym, Instytut Europeistyki Uniwersytet Jagielloński, Kraków-Przegorzały 2009.

Pałka R., Globalizacja i integracja regionalna a rola państwa, "Gazeta Innowacje”, nr 18/2003.

Pancer-Cybulska E., Uwarunkowania samorządności lokalnej i regionalnej w Polsce w aspekcie kreowania i wzrostu konkurencyjności, [w:] M. Klamut (red.), Konkurencyjność regionów, Wydawnictwo Akademii Ekonomicznej we Wrocławiu, Wrocław 1999.

Parzymies S., Europa regionów, "Sprawy Międzynarodowe”, nr 3/1994.

Pearce D., Economics, Equity and Sustainable Development, „Futures”, vol. 20, no 6/1988. 
Perkowski M., Prawo zarządzania projektami finansowymi z funduszy europejskich, Wydawnictwo Wolters Kluwer, Warszawa 2008.

Perkowski M., Współpraca transgraniczna. Aspekty prawno-ekonomiczne, Fundacja Prawo i Partnerstwo, Białystok 2010.

Pietrzyk I., Polityka regionalna Unii Europejskiej i regiony w państwach członkowskich, Wydawnictwo Naukowe PWN, Warszawa 2002.

Piontek B., Koncepcja rozwoju zrównoważonego i trwałego Polski, Wydawnictwo Naukowe PWN, Warszawa 2002.

Pisarenko S., Bariery społeczno-gospodarcze ukraińsko-polskiej współpracy transgranicznej, [w:] J. Kitowski, Czynniki i bariery regionalnej współpracy transgranicznej - próba syntezy, Wydział Ekonomiczny Filii Uniwersytetu Marii Curie-Skłodowskiej, Rzeszów 1998.

Podskrobko B., Teoretyczne aspekty ekorozwoju, ,Ekonomia i Środowisko", nr 1(10)/1997.

Podskrobko B., Zarządzanie środowiskiem, Wydawnictwo PWE, Warszawa 1998.

Porter M.E., Porter o konkurencji, Wydawnictwo PWE, Warszawa 2001.

Proniewski M., Wpływ granicy i współpracy transgranicznej na rozwój regionalny i lokalny regionu północno-wschodniego, [w:] A. Mync, R. Szul (red.), Rola granicy i współpracy transgranicznej w rozwoju regionalnym i lokalnym, Europejski Instytut Rozwoju Regionalnego, Warszawa 1999.

Proniewski M., Uwarunkowania i kierunki polityki rozwoju regionalnego Unii Europejskiej, „Przestrzeń i Regiony. Rocznik Wydziału Gospodarki Przestrzennej Wyższej Szkoły Finansów i Zarządzania", nr 2/2013.

Pułkownik J., Euroregion Pro Europa Viadrina jako przykład współpracy transgranicznej, „Zeszyty Studiów Doktoranckich/Uniwersytet Ekonomiczny w Poznaniu", nr 43/2005.

Radek R., Znaczenie współpracy transgranicznej w rozwoju społeczności lokalnych i regionalnych, Uniwersytet Śląski Wydział Nauk Społecznych Instytut Nauk Politycznych i Dziennikarstwa, Katowice 2007.

Rasz H., Euroregiony na granicach Polski, Biuro Studiów i Ekspertyz, Informacja nr 686/1999.

Richardson H.W., Regional policy in a slow-growth economy, [w:] G. Demko (ed.), Regional Development Problems and Policies in Eastern and Western Europe, Croom Helm, London 1984.

Rokicki B., Teoria ekonomiczna a regionalne zróżnicowanie rynku pracy, Uniwersytet Warszawski, Warszawa 2008.

Romer P.M., Endogenous Technological Change , ,Journal of Political Economy", no 98/1990.

Rosińska M., Analiza ekonomiczna przedsiębiorstwa w oparciu o teorie instytucjonalne - koncepcja „instytucjonalizmu organizacyjnego przedsiębiorstw" , „Acta Universitatis Lodziensis. Folia Oeconomica", nr 221/2008.

Różycki S., Idea euroregionalizacji i jej ocena na przykładzie badań ankietowych w euroregionie Nysa, Wydawnictwo Akademii Ekonomicznej, Liberez 1995.

Rudnicki M., Polityka regionalna Unii Europejskiej, Wydawnictwo Wyższej Szkoły Bankowej, Poznań 2000.

Rumianowska I., Euroregionalny Program Rozwoju Zrównoważonego w Euroregionie Sprewa -Nysa-Bóbr, [w:] B. Fiedor, J. Rymarczyk (red.), Ekonomia i międzynarodowe stosunki gospodarcze, Wydawnictwo Akademii Ekonomicznej im. Oskara Langego, Wrocław 2007. 
Sagan I., Współczesne studia regionalne - teoria i metodologia, a także praktyka, „Studia Regionalne i Lokalne", nr 2(16)/2004.

Sala S., Wpływ procesów globalizacji na region, „Prace Komisji Geografii Przemysłu”, nr 10/2008.

Schurr Ch., Lasy - żywa wymiana w zielonej części Euroregionu Nysa, [w:] M. Zdulski (red.), 20 lat współpracy transgranicznej w Euroregionie Neisse-Nysa-Nisa, Wydawnictwo Ad Rem, Jelenia Góra 2011.

Simmie J., Innovation and urban regions as national and international nodes for the transfer and sharing of knowledge ,"Regional Studies”, vol. 37, no 6-7/2003.

Skoczek T., Wpływ lokalizmu i regionalizmu na media, „,Kultura”, nr 1(27)/2009.

Skorowski H., Antropologiczno-etyczne aspekty regionalizmu, Wydawnictwo Salezjańskie, Warszawa 1990.

Skowroński A., Zrównoważony rozwój perspektywą dalszego postępu cywilizacyjnego „Problemy Ekorozwoju", t. 1, nr 2/2006.

Sodu K., Foreign Direct Investment for Development. Maximizing Benefits Minimizing Costs, OECD Report 2002.

Stappen R., Raport Brundtland, New York 2006.

Stec M., Znaczenie funduszy pomocowych Unii Europejskiej dla spójności społeczno-gospodarczej polskich regionów, „Modernizacja dla spójności społeczno-ekonomicznej”, nr 18/2008.

Stroper M., The Regional Word. Territorial Development in a Global Economy, The Guilford Press, New York 1997.

Strzelec J., Doświadczenia i wyzwania rozwoju regionalnego w latach 1999-2013 na przykładzie województwa świętokrzyskiego, Wydawnictwo Uniwersytetu Humanistyczno-Przyrodniczego im. Jana Kochanowskiego, Kielce 2010.

Strzeszewski C., Katolicka nauka społeczna, Ośrodek Dokumentacji i Studiów Społecznych, Warszawa 1985.

Suchocka R., Regiony w procesie europejskiej integracji, [w:] P. Buczkowski, K. Bondyra, P. Śliwa (red.), Jaka Europa? Regionalizacja a integracja, Wydawnictwo Wyższej Szkoły Bankowej, Poznań 1998.

Szadkowska E., Pojęcie współpracy transgranicznej, [w:] M. Perkowski, Współpraca transgraniczna. Aspekty prawno-ekonomicznego, Fundacja Prawo i Partnerstwo, Białystok 2010.

Szadkowska E., Prawny wymiar współpracy transgranicznej, [w:] M. Perkowski, Współpraca transgraniczna. Aspekty prawno-ekonomicznego, Fundacja Prawo i Partnerstwo, Białystok 2010.

Szlachta J., Dziemianowicz W., Nowicka P., przy współpracy Urzędów Marszałkowskich Województw Dolnośląskiego, Lubuskiego, Opolskiego, Wielkopolskiego i Zachodniopomorskiego, Założenia Strategii Rozwoju Polski Zachodniej, Geoprofit, Wrocław-Opole-Gorzów Wielkopolski-Szczecin 2012.

Szyjko C.T., Enigma nowego regionalizmu europejskiego, Wydawnictwo i Drukarnia „Złote Myśli”, Warszawa 2010.

Szymla Z., Podstawy badań rozwoju regionalnego, „Zeszyty Naukowe Wyższej Szkoły Ekonomicznej w Bochni", nr 3/2005. 
Ślusarz G., Czynniki rozwoju społeczno-gospodarczego - aspekty teoretyczne, [w:] A. Czudec, G. Ślusarz (red.), Regionalne uwarunkowania rozwoju wiejskich obszarów przygranicznych Polski i Ukrainy, Wydawnictwo Uniwersytetu Rzeszowskiego, Rzeszów 2003.

Świeca A., Brzezińska-Wójcik T., Region w ujęciu geograficznym, [w:] M. Dziekanowska, J. Styka (red.), Region w koncepcjach teoretycznych i diagnozach empirycznych, Wydawnictwo Perfecta Info, Lublin 2008.

Świeca J., Regionalizacja i federalizm, a ustrojowa kwestia elastyczności europejskich systemów demokratycznych na przykładzie Szwajcarii, Belgii i Niemiec, Wyższa Szkoła Zarządzania i Marketingu w Sosnowcu, Sosnowiec 2004.

Toczyński W., Sartorius W., Zaucha J., Międzynarodowa współpraca regionów. Wybór ekspertyz, Przedświt, Warszawa 1997.

Tödtling F., Trippl M., One size fits all? Towards a differentiated regional innovation policy approach, „Research Policy”, vol. 34, no 8/2005.

Tomaszewski K., Regiony w procesie integracji europejskiej, Oficyna Wolters Kluwer Polska, Kraków 2007.

Trojan S.S., Tyszczenko J., Wpływ procesów demokratyzacji w państwach Europy Środkowo-Wschodniej na współpracę transgranicznq, [w:] M. Malikowski, D. Wojakowski, Granice i pogranicza nowej Unii Europejskiej: Z badań regionalnych, etnicznych i lokalnych, Wydawnictwo Nomos, Kraków 2005.

Waldziński D., Polityka regionalna w Polsce w procesie przemian kulturowo-cywilizacyjnych. Zarys problemu, Wydawnictwo Uniwersytetu Warmińsko-Mazurskiego, Olsztyn 2005.

Warych-Juras A., Euroregiony jako nowa forma współpracy europejskiej, "Informator Polskiego Towarzystwa Geograficznego Oddział w Krakowie", t. 1/2003.

Weidenfeld W., Wessels W., Europa od A do Z, Wydawnictwo „Wokół Nas”, Gliwice 1999.

Weinkauf A., Kajcińska M., Diagnoza demograficzno-epidemiologiczna dotyczq̨ca osób starszych w Polsce i na Mazowszu w latach 2004-2005, Mazowieckie Centrum Zdrowia Publicznego, Warszawa 2006.

Wilde de E., Ten years of European outline convention on transfrontier co-operation - Results and new prospects, [w:] Council of Europe, 5th European Conference of Frontier Regions Rovaniemi/ Finland, 18-21 June 1991.

Winiarski B., Polityka gospodarcza, Wydawnictwo Naukowe PWN, Warszawa 2006.

Winzeler M., Historia, [w:] M. Zdulski, 20 lat współpracy transgranicznej w Euroregionie Neisse -Nysa-Nisa, Wydawnictwo Ad Rem, Jelenia Góra 2011.

Witkowska J., Bezpośrednie inwestycje zagraniczne w Europie Środkowowschodniej na gruncie teorii bezpośrednich inwestycji zagranicznych, Wydawnictwo Uniwersytetu Łódzkiego, Łódź 1996.

Witkowska J., Spójność społeczno-gospodarcza Unii Europejskiej-pozycja Polski i jej regionów, „Problemy Zarządzania”, vol. 8, nr 1(27)/2010.

Wlaź A., Instytucje Unii Europejskiej, Ministerstwo Spraw Zagranicznych, Warszawa 2010.

Wlaźlak K., Rozwój regionalny jako zadanie administracji publicznej, Oficyna Wolters Kluwer Polska, Warszawa 2010. 
Wojnicka E., Rot P., Tamowicz P., Brodzicki T., Regionalny system innowacyjny w województwie pomorskim, „Polska Regionów”, nr 26/2001.

Wosiek M., Współczesna teoretyczna koncepcja regionu ekonomicznego, [w:] А.A. Ткач (red.), Інститучіональний вектор економічного розвитку, збірник наукових праць, Випуск 1(2), МІДМУ „КПУ", Mielitopol 2008.

Woś B., Europejska integracja a podmiotowość regionów, [w:] Z. Mikołajewicz (red.), Uwarunkowania i strategie rozwoju regionalnego w procesach europejskiej integracji, Wydawnictwo Uniwersytetu Opolskiego, Opole 2000.

Woś B., Rozwój regionów i polityka regionalna w Unii Europejskiej oraz w Polsce, Oficyna Wydawnicza Politechniki Wrocławskiej, Wrocław 2005.

Woźniak-Hasik Z., Trendy demograficzne dotyczq̨ce wieku w UE, Materiały szkoleniowe, Dział Programów Zdrowotnych i Promocji Zdrowia Mazowieckie Centrum Zdrowia Publicznego, Warszawa 2007.

Wysocka E., Teoretyczne podstawy konkurencyjności w planowaniu przestrzennym, Wydawnictwo IGPiK, Warszawa 2001.

Wysocka E., Istota i czynniki konkurencyjności w regionie, „Wójt i Jego Gmina”, nr 5/2006.

Wysokińska Z., Witkowska J., Integracja europejska, Wydawnictwo Naukowe PWN, WarszawaŁódź 1999.

Zając M., Zadania polityki regionalnej Unii Europejskiej wobec wzrostu zróżnicowań regionalnych zwiqzanych z ostatnim rozszerzeniem, „Zeszyty Naukowe Akademii Ekonomicznej w Krakowie", nr 701/2006.

Zaufal B., Białecka M., Ekorozwój szansą przetrwania cywilizacji - materiały z konferencji Polskiego Klubu Ekologicznego, Wydawnictwo Akademii Górniczo-Hutniczej, Kraków 1986.

Źurba I., Euroregion jako najbardziej zaawansowany organizacyjnie i funkcjonalnie poziom współpracy transgranicznej, „Nierówności Społeczne a Wzrost Gospodarczy”, nr 12/2008.

Żebrowska J., Angielsko-polski słownik dla beneficjentów programu PHARE spójność gospodarcza i społeczna, Polska Agencja Rozwoju Regionalnego, Warszawa 2001.

Żelazo A., Pojęcie współpracy transgranicznej samorzq̨du terytorialnego, „Polski Instytut Spraw Międzynarodowych. Biuletyn", nr 24(212)/2004.

Żelazo A., Współpraca międzynarodowa gmin przygranicznych „,,Polski Instytut Spraw Międzynarodowych. Biuletyn. Seria Z", nr 59/2002.

Żuber P., Rozwój regionalny w Polsce. Raport 2009, Ministerstwo Rozwoju Regionalnego, Warszawa 2009.

\section{Artykuły ze źródeł internetowych}

Chruski P., Programy wspólnotowe i ich struktura w systemie środków pomocowych dla Polski, Wyższa Szkoła Humanistyczno-Ekonomiczna we Włocławku, http://www.staff.amu.edu.pl/ chur/biblio grafia/PROGRAMY\%2OWSPOLNOTOWE.pdf [dostęp 12.07.2012]. 
Dubowska A., Polityka regionalna Unii Europejskiej - ewolucja koncepcji w kontekście pogłębiania integracji, http://civitaseuropae.eu/wp-content/uploads/2009/02/anna_dubowska_regiony. pdf [dostęp 03.03.2014].

Dutkowski M., Polityka regionalna w Unii Europejskiej, www.zpsb.szczecin.pl [dostęp 15.12.2012].

Fiedor B., Nowa Ekonomia Instytucjonalna jako podstawa teoretycznej refleksji nad procesem transformacji od gospodarki centralnie sterowanej do rynkowej, Otwarty Uniwersytet Ekonomiczny Wiedzainfo.pl, http://www.wiedzainfo.pl [dostęp 10.10.2012].

Godowska M., Region uczący się - uwarunkowania i determinanty rozwoju na przykładzie województwa małopolskiego, http://p-e.up.krakow.pl/article/viewFile/126/65 [dostęp 10.02.2012].

Góra J., Model dynamiki klastra jako narzędzie badania możliwości adaptacyjno-rozwojowych klastra, http://www.instytut.info/IVkonf/referaty/Gora.pdf [dostęp 10.09.2014].

Hadyńska A., Komitet Regionów a wielopoziomowe sprawowanie rządów w Unii Europejskiej, http://euro.ue.poznan.pl/pl/konferencja/535/fb1324cf04d3d3eaec06a811fbe6903cfb 1324cf04d3d3eaec06a811fbe6903c [dostęp 12.02.2014].

Jarosz-Angowska A., Zróżnicowanie regionalne gospodarki, http://www.studium.agrobiznesu. up.lublin.pl/images/materialy/w2.pdf [dostęp 14.12.2012].

Klamut M., Cele i narzędzia polityki regionalnej Unii Europejskiej, http://www.pzdu.pl/uploads/ files/konferencje/1/08_Miroslawa_Klamut.pdf [dostęp 15.01.2013].

Kochmańska M., Regionalne systemy innowacji, http://www.sbc.org.pl [dostęp 10.02.2012].

Komosa I., Łączq̨c Europę (Connecting Europe Facility), http://www.uniaeuropejska.org/qczc-eu ropq-connecting-europe-facility [dostęp 10.12.2013].

Kudłacz T., Lityński P., Analiza pięciu strategii regionalnych województw polski zachodniej i problemów stykowych pomiędzy województwami polski zachodniej z innymi regionami, https://www. polskawschodnia.2007-2013.gov.pl/analizyraportypodsumowania/documents/kudlacz.pdf [dostęp 12.04.2015].

Kuźmicka J., Bentkowska J., Współpraca transgraniczna w euroregionie Pradziad, http://www.euro pradziad.pl/doce/050123_wspolpraca.doc [dostęp 26.05.2015].

Lechwar M., Instytucjonalne podstawy europejskiej współpracy transgranicznej, http://www.univ.rze szow.pl/nauka/konferencje/rl_most/02-Lechwar.pdf [dostęp 15.03.2014].

Lewandowski A., Regionalizmy i lokalizmy, Katowice, europrojekty.pl [dostęp 15.02.2014].

Macios K., Regionalizm i współpraca regionalna, wos.org.pl [dostęp 10.08.2012].

Michałowska-Gorywoda K., Instytucje finansowe unii europejskiej, http://www.nbportal.pl/library/ pub_auto_B_0002/KAT_B2008.PDF [dostęp 05.10.2009].

Miszczuk A., Współpraca transgraniczna, http://www.euroreg.uw.edu.pl/doc/Akademia2007_ 2008/Sesja_IX/MISZCZUK/Miszczuk_wspolpraca_transgraniczna.pdf [dostęp 17.05.2014].

Olbrycht J., Status regionów a programowanie na poziomie regionalnym, Ekspertyza na zlecenie Departamentu Koordynacji Polityki Strukturalnej w MGPiPS, Warszawa, 2004, http://www. funduszestrukturalne.gov.pl [dostęp 17.06.2012].

Osowska A., NUTS (nowe jednostki terytorialne dla celów statystycznych), http://www.profesor. pl/publikacja,12299,Artykuly,NUTS-nowe-jednostki-terytorialne-do-celow-statystycznych [dostęp 14.12.2012]. 
Stabińska A., Historia i rola Komitetu Regionów, http://www.mazovia.pl/komitet-regionow/histo ria-i-rola-komitetu-regionow [dostęp 10.01.2014].

Szlachta J., Europejski Fundusz Rozwoju Regionalnego - szansa dla Polski, http://www.bzfe.uw.gda. pl/download/Europejski\%20Fundusz\%20Rozwoju\%20Regionalnego.pdf [dostęp 15.05.2014].

Szlachta J., Strategia Europa 2020 a europejska polityka spójności po 2013 roku, http://kolegia.sgh. waw.pl/pl/KAE/struktura/IRG/publikacje/Documents/pim88_9.pdf [dostęp 01.03.2014].

Willak W., Polityka spójności na lata 2007-2013, http://www.malopolskie.pl/Pliki/2006/4_CONF24FEB2006WWillakPL.pdf [dostęp 16.05.2014].

Zbroja Z., Transgraniczny Klaster Turystyczny - szlak wodny Berlin-Szczecin-Bałtyk, http://www. zagle.com.pl/srodladzie/locja/transgraniczny-klaster-turystyczny-szlak-wodny-ber,33_6731. html [dostęp 10.05.2015].

\section{Dokumenty i akty prawne}

Commitee des Regions, The EU's Assembly of Regional and Local Representatives, Committee of the Regions at a glance, Information Brochure.

Commitee of the Regions, Regional and local democracy in the European Union, Brussels, 1999.

Committee of the Regions, 114th Meeting of the Committee of the Regions Bureau, Brussels, 28 January 2009.

Council of Europe, Explanatory report on the European Charter of Local Self-Government, Strasbourg 1984.

Deutsche Projekt Union sp. z o.o. We współpracy z FVR Verkehrslogistik und Regionalplanung $\mathrm{GmbH}$, Rostock oraz AHT INTERNATIONAL GmbH, Essen, Transgraniczna Koncepcja rozwoju i działania Euroregionu Pomerania na lata 2000-2006, Berlin 1999.

Dokumentacja Rady Europy: Final activity report of the Steering Commitee on Local and Regional Democracy (CDLR) to the Commitee of Ministers on the complation of the groundwork for the elaboration of legal instrument on regional self-government.

Dyrektywa 92/43/EWG Rady z 21 maja 1992 r. o obszarach FFH - dyrektywa siedliskowa, dyrektywa 79/409/EWG Rady z 2 kwietnia 1979 r. (dyrektywa ptasia).

European Parliament. Directorate General for Research, Regionalisation in Europe, Working Paper, Regional Policy Series REGI 108aXX.

European Trend Chart on Innovation. Thematic Report Cluster Policies, Covering Period up to March 2003, European Comission Enterpreise Directorate General.

Europejska Karta Samorządu Lokalnego, Dz.U. z 1994 r., nr 124, poz. 607.

Europejska Konwencja Ramowa o Współpracy Transgranicznej między Wspólnotami i Władzami Terytorialnymi sporządzona w Madrycie dnia 21 maja 1980 r., Dz.U. z dnia 10 lipca 1993 r.

Europejski Komitet Ekonomiczno-Społeczny, Opinia Europejskiego Komitetu Ekonomiczno-Społecznego w sprawie euroregionów, (2007/C 256/23), 17 stycznia 2007 r.

Euroregion Sprewa-Nysa-Bóbr, Plan działania i rozwoju Euroregionu Sprewa-Nysa-Bóbr na lata 2014-2020, Zielona Góra/Poczdam, 1 marca 2013 r. 
Komisja Europejska Dyrekcja ds. polityki regionalnej, Urząd publikacji Unii Europejskiej, Polityka spójności 2014-2020, Inwestycje w rozwój gospodarczy i wzrost zatrudnienia, Luksemburg 2011. Komisja Europejska, Polityka spójności 2007-2013. Komentarze i teksty oficjalne, Belgia 2007. Kommunalgemeinschaft Europaregion Pomerania, Stowarzyszenie Gmin Polskich Euroregionu Pomerania, Transgraniczna koncepcja rozwoju i działania Euroregionu Pomerania na lata 2014-2020, Szczecin.

Komunikat Komisji, EUROPA 2020 Strategia na rzecz inteligentnego i zrównoważonego rozwoju sprzyjającego włączeniu społecznemu.

Koncepcja Rozwoju i Działania Euroregionu PRO EUROPA VIADRINA Viadrina 2014, Gorzów Wielkopolski-Frankfurt (Oder) 2013.

Ministerstwo Środowiska, Raport dla Obszaru Dorzecza Odry z realizacji art. 5 i 6, zał. II, III, IV Ramowej Dyrektywy Wodnej 2000/60/WE, Warszawa 2005.

Mitteilung der Kommission an den Rat und das Europäische Parlament, Gemeinsame Maßnahmen für Wachstum und Beschäftigung: Das Lissabon-Programm der Gemeinschaft, KOM (2005).

Problemy polsko-ukraińskiej współpracy przygranicznej, Biuletyn PAN IGiPZ, nr 9/1995.

Projekt Narodowego Planu Rozwoju na lata 2007-2013, Warszawa 2005.

Przedstawicielstwo Komisji Europejskiej w Polsce, Co to jest PHARE?, Przedstawicielstwo Komisji Europejskiej w Polsce wspólnie z Wydawnictwem Wokół nas, Warszawa.

Przewodnik LACE: część 1. Rozwój ekonomiczny.

Rada Europy, Europejska Konwencja Ramowa o współpracy transgranicznej między wspólnotami i władzami terytorialnymi - dokument Rady Europy podpisany 21 maja 1980 r. w Madrycie.

Regional and Local Powers In Europe, Commitee of the Regions, Brussels 2002.

Regional structures in the applicant countries and their compatibility with the Structural Funds, EP. Directorate General for Research, PE No. 311.200, kwiecień 2002.

Rezolucja Parlamentu Europejskiego w sprawie znaczenia spójności terytorialnej w rozwoju regionalnym (2004/2256(INI)), Znaczenie spójności terytorialnej dla rozwoju regionalnego, Dziennik Urzędowy Unii Europejskiej C 227 E/509, 28 września 2005 r.

Stowarzyszenie Europejskich Regionów Granicznych, Praktyczny przewodnik współpracy transgranicznej, Warszawa 1997.

Traktat z Lizbony zmieniający Traktat o Unii Europejskiej i Traktat ustanawiający Wspólnotę Europejską podpisany w Lizbonie dnia 13 grudnia 2007 r. Dziennik Urzędowy C 306 z 17 grudnia 2007, art. 4.

Transgraniczny Związek Euroregion Tatry, Wspólna polsko-słowacka Strategia Rozwoju Euroregionu "Tatry" na lata 2008-2015.

Unity, Solidarity, Diversity for Europe, its People and its Territory. Second Report on Economic and Social Kohesion, Statistical Annex, European Kommission, Brussels, January 2001.

Vorschlag für einen Beschluss des Europäischen Parlaments über das siebte Rahmenprogramm für Forschung, Technologie und Demonstration (2007-2013), 06.04.2005, KOM(2005)119 endgültig.

W.O.W. Kommunalberatung und Projektbegleitung GmbH/Döllinger Architekten Inregia AB Stockholm Inros Lackner AG Rostock Regionalne Biuro Gospodarki Przestrzennej Województwa 
Zachodniopomorskiego, Transgraniczna koncepcja działań i rozwoju Euroregionu POMERANIA na lata 2007-2013, sierpień 2006, Szczecin.

Wspólnotowa Karta Regionalizacji, Aneks do rezolucji o polityce regionalnej Wspólnoty i o roli regionów, Official 1989, Council 1996.

Znaczenie spójności terytorialnej dla rozwoju regionalnego, Rezolucja Parlamentu Europejskiego w sprawie znaczenia spójności terytorialnej w rozwoju regionalnym (2004/2256(INI)), Dziennik Urzędowy Unii Europejskiej C 227 E/509, 28 września 2005 r.

Annule et remplace le document $\operatorname{COM(2011)611~du~6.10.2011~Concerne:~toutes~les~versions~}$ linguistiques, Wniosek Rozporządzenie Parlamentu Europejskiego w sprawie przepisów szczegółowych dotyczących wsparcia z Europejskiego Funduszu Rozwoju Regionalnego w ramach celu „Europejska współpraca terytorialna”, Bruksela, dnia 14.3.2012 r. COM(2011) 611 final/2 2011/0273 (COD).

\section{Źródła internetowe}

http://20090209.archiwa.gov.pl/repository/wspolpraca/Fundusze_strukturalne.pdf [dostęp 15.05.2014].

http://archiwumukie.polskawue.gov.pl/HLP/files.nsf/0/81B767C7051F6C90C1256E7B004840F6/

\$file/EUROREGI.PDF [dostęp 12.07.2014].

http://berlin-szczecin-baltyk.pl/ [dostęp 16.05.2015].

http://ec.europa.eu/employment_social/esf/discover/participate_en.htm [dostęp 10.05.2014]. http://ec.europa.eu/regional_policy/sources/docgener/presenta/working2008/work_pl.pdf

[dostęp 16.05.2015].

http://europa.eu/about-eu/institutions-bodies/cor/index_pl.htm [dostęp 11.04.2014].

http://europa.eu/rapid/press-release_MEMO-13-1011_pl.htm [dostęp 19.11.2013].

http://euroregionbug.pl/content/view/10/8/ [dostęp 13.06.2015].

http://euroregion-nysa.pl [dostęp 10.10.2014].

http://euroregionsnb.pl/media/dokumenty/Ogolne/plan_rozwoju_i_dzialania_euroregionu_

sprewa_nysa_bobr.pdfs.65 [dostęp 15.05.2015].

http://euroregion-snb.pl/o_nas/wladze [dostęp 15.04.2014].

http://euroregion-viadrina.pl/content/struktura-i-schemat-organizacyjny-0 [dostęp 12.04.2015]. http://klubue.3lo.pl/index.php?option=com_content\&view=article\&id=110\&ltemid=86 [dostęp

10.03.2014].

http://lukdan.vxm.pl/karpacki/podstawy_prawne.html\#umowy [dostęp 04.04.2013].

http://marketcontact.eu/pl/wiadomosci-gospodarcze/91-euroregiony.html [dostęp 12.09.2014]. http://old.ue.poznan.pl/att/DZIEK_EKON/j.pulkownik_z43.pdf [dostęp 10.04.2015].

http://pliki.euroregion-snb.pl/umowa_snb.pdf [dostęp 15.04.2015].

http://polskazachodnia2020.pl/attachments/article/14/Wykorzystanie\%20po\%C5\%82o\%C5\%BCenia

\%20przygranicznego....J.\%20Zaleski.pdf [dostęp 10.08.2014].

http://pomerania.org.pl/file.php?id=8 [dostęp 10.09.2013]. 
http://uniaeuropejska.org/unia/files/encyklopedia/EFS_MKarapuda_\%20FKE.pdf [dostęp 12.01.2013].

http://www.btg.boleslawiec.pl/index.php?cat=6\&id=77 [dostęp 19.08.2015].

http://www.cie.gov.pl [dostęp 12.01.2015].

http://www.ern.cz/analyza/ern_cz/pl/index.php?D=10 [dostęp 22.06.2014].

http://www.euractiv.pl/innowacyjnosc-i-kreatywnosc/wywiad/raport-komisji-europejskiej-w-

sprawie-zrownowaonego-rozwoju-001161 [dostęp 10.02.2012].

http://www.eurobalt.org.pl/index.php [dostęp 17.08.2014].

http://www.euroregion-beskidy.pl/pl/images/stories/zdjecia/strategiaerb.pdf [dostęp 15.05.2015]. http://www.euroregionbug.pl/content/view/12/18/ [dostęp 17.06.2015].

http://www.euroregion-silesia.eu [dostęp 17.02.2014].

http://www.euroregion-viadrina.de/cms/upload/EHK_2014_-_2020_polnische_Printfassung_-_

Download.pdf [dostęp 10.09.2013].

http://www.euroregion-viadrina.pl/content/wsparcie-lubuskich-przedsi\%C4\%99biorc\%C3\%

B3w-\%E2\%80\%93-bezp\%C5\%82atne-spotkanie-informacyjne-\%E2\%80\%93-30042015 [do-

stęp 17.10.2015].

http://www.ewt.gov.pl/WstepDoFunduszyEuropejskich/Strony/Beneficjenci.aspx [dostęp

02.03.2013].

http://www.ewt.wzp.pl/ewt/ewt_2007-2013/europejska_wspolpraca_terytorialna_2007_-_2013.

htm [dostęp 02.03.2013].

http://www.funduszspojnosci.gov.pl/Podstawowe+informacje/ [dostęp12.05.2013].

http://www.greenways.olza.pl/ [dostęp 12.04.2014].

http://www.jawor.pl/pliki/8/strategia-rozwoju-euroregionu-nysa-2014-2020-pl.pdf [dostęp

06.09.2015].

http://www.kamillo.bpl.vectranet.pl/eurokraszak/PODSTRONY/euroregiony.htm [dostęp

16.05.2014].

http://www.karpacki.pl/euroregion-fundusze_unijne-dane_ogolne-35.html [dostęp 12.06.2014].

http://www.karpacki.pl/euroregion-karpacki/euroregiony-w-/ [dostęp 10.02.2014].

http://www.mrr.gov.pl/aktualnosci/rozwoj_regionalny/Strony/Reforma_polityki_spojnosci_wla

tach07_13_Implikacie_FE_209.aspx [dostęp 12.01.2013].

http://www.neisse-nisa-nysa.org/index.php?id=69\&L=2 [dostęp 27.08.2013].

http://www.niemen.org.pl/index.php?option=com_content\&view=category\&layout=blog\&id=

2\&ltemid=4\&lang=pl [dostęp 17.08.2014].

http://www.opzl.pl/dzialalnosc/projekty/17,wikob_biuro_koordynacji_gospodarczej_eurore-

gionu_sprewa-nysa-bobr [dostęp 17.08.2015].

http://www.pomerania.net/download/EHK_POMERANIA_2007-13_Endfassung_PL.pdf [dostęp 18.03.2013].

http://www.pomerania.org.pl/site/aktualnosci/172 [dostęp 17.12.2015].

http://www.portfel.pl/pdf/art773 [dostęp 17.03.2013].

http://www.powiat-olsztynski.pl/t2/index.php?page=projlyna [dostęp 17.08.2014].

http://www.regiontransmanche.com/index.html [dostęp 25.04.2014].

http://www.regioset.pl/monitor.php?lg=0\&art=7\&unit=5 [dostęp 15.04.2013]. 
http://www.stat.gov.pl/cps/rde/xbcr/wroc/ASSETS_14-19.pdf [dostęp 20.05.2014].

http://www.strasburgre.msz.gov.pl/pl/o_re/o_radzie_europy_info/ [dostęp 14.02.2014] http://www.szczecin.pl/umszczecinSwiat/chapter_59233.asp?soid=03ADDC51251D42AB8699F 53EAAFCB6CB [dostęp 10.11.2015].

http://www.wrotapodlasia.pl/pl/region/wspolpraca_zagraniczna/euroregiony/puszcza_ bia\%C5\%82owieska/ [dostęp 14.08.2014].

http://www.wup-rzeszow.pl/sporzl/files/63_WytyczneEFS_aktualizacja180306.pdf [dostęp 10.05.2014].

https://polskawue.gov.pl/Komitet,Regionow,(KR),,czlonkowie,329.html [dostęp 10.01.2014]. https://www.ewt.gov.pl/strony/o-programach/przeczytaj-o-programach/urbact-iii/ [dostęp 23.05.2015]. 


\section{Spis schematów}

1.1. Ujęcia definicyjne „regionu" - zmiany w czasie $\quad 15$

1.2. Ujęcia definicyjne „regionu” - wielowymiarowość 16

1.3. Typologia regionów wg L. Klassena $\quad 22$

2.1. Działania w ramach strategii Europa $2020 \quad 48$

3.1. Rodzaje współpracy terytorialnej 64

3.2. Główne przesłanki rozwoju współpracy transgranicznej w Europie 65 



\section{Spis tabel}

1.1. Etapy rozwoju regionalizmu $\quad 17$

1.2. Wybrane współczesne koncepcje rozwoju regionalnego 28

2.1. Etapy polityki regionalnej UE 43

2.2. Instrumenty pomocy przedakcesyjnej 46

2.3. Ewolucja programu PHARE

2.4. Edycje Programu Interreg 58

5.1. Euroregion Pomerania - podstawowe informacje $\quad 110$

5.2. Euroregion Pro Europa Viadrina 111

5.3. Euroregion Sprewa-Nysa-Bóbr 112

5.4. Euroregion Neisse-Nisa-Nysa 112

5.5. Prognoza liczby ludności wg grup wiekowych w Euroregionie Pomerania $\quad 118$

$\begin{array}{ll}\text { 5.6. Wybrane dane o edukacji w Euroregionie Pomerania } & 121\end{array}$

5.7. Wybrane dane o edukacji w Euroregionie Pro Europa Viadrina 122

5.8. Wybrane dane o edukacji w Euroregionie Sprewa-Nysa-Bóbr 122

5.9. Wybrane dane o edukacji w Euroregionie Neisse-Nisa-Nysa 123

5.10. Zasoby mieszkaniowe w euroregionach na pograniczu zachodnim (2010 r.) $\quad 124$

5.11. Liczba lekarzy na 100 tys. mieszkańców 125

5.12. Liczba łóżek w szpitalach na 100 tys. mieszkańców 125

5.13. Liczba turystów odwiedzających euroregiony 131

6.1. Analiza SWOT euroregionów zachodniego pogranicza Polski 145

6.2. PKB per capita w Euroregionie Pomerania (w cenach bieżących: euro) 147

6.3. PKB per capita w Euroregionie Pro Europa Viadrina (w cenach bieżących: euro) $\quad 148$

6.4. PKB per capita w Euroregionie Sprewa-Nysa-Bóbr (w cenach bieżących: euro) 148

6.5. PKB per capita (euro) w Euroregionie Neisse-Nisa-Nysa 149

6.6. Stopa bezrobocia w Euroregionie Pomerania (\%) 150

6.7. Stopa bezrobocia w Euroregionie Pro Europa Viadrina (\%) 150

6.8. Stopa bezrobocia w Euroregionie Sprewa-Nysa- Bóbr (\%) 151

6.9. Stopa bezrobocia w Euroregionie Neisse-Nisa-Nysa (\%) 151

6.10. Wskaźnik generowania odpadów komunalnych w euroregionach (1000 t) 152 
6.11. Materiały poddane recyklingowi (tys. ton) 153

6.12. Wskaźnik HDD "stopniodzień ogrzewania” w euroregionach 154

7.1. Alokacja funduszy unijnych w euroregionach zachodniego pogranicza Polski (euro) 163

7.2. Wystandaryzowane wskaźniki rozwoju dla euroregionów oraz wskaźnik Perkala $\begin{array}{ll}\text { (WP) na zachodnim pograniczu Polski } & 169\end{array}$

7.3. Wybrane statystyki opisowe dla wskaźników zrównoważonego rozwoju 171

7.4. Korelacje pomiędzy rozwojem poszczególnych euroregionów. Oznaczone współ$\begin{array}{ll}\text { czynniki korelacji są istotne z } p<, 05000 N=15 & 173\end{array}$

7.5. Korelacje. Oznaczone wsp. korelacji są istotne z $p<, 05000 N=15$

7.6. Estymacja KMNK, wykorzystane obserwacje 2000-2014 (N=15) 175

7.7. Wskaźnik Florence'a w Euroregionach zachodniego pogranicza Polski w 2014 r. $\quad 178$

7.8. Wskaźnik absorbcji środków z Funduszu Małych Projektów w euroregionach $\quad 179$

7.9. Wyniki statystycznej analizy regresji (Klasyczna Metoda Najmniejszych Kwadratów) dla zmiennych Zrównoważony rozwój i Skumulowane przepływy środków z UE 


\section{Spis wykresów}

$\begin{array}{ll}\text { 5.1. Liczba ludności w Euroregionie Pomerania } & 117\end{array}$

5.2. Liczba ludności w Euroregionie Pro Europa Viadrina 118

5.3. Procentowy udział grup wiekowych w Euroregionie Pro Europa Viadrina $\quad 119$

5.4. Liczba ludności w Euroregionie Sprewa-Nysa-Bóbr 119

5.5. Procentowy udział grup wiekowych w Euroregionie Sprewa-Nysa-Bóbr $\quad 120$

5.6. Euroregion Neisse-Nisa-Nysa 120

5.7. Procentowy udział grup ludnościowych w Euroregionie Neisse-Nisa-Nysa $\quad 120$

6.1. Procent populacji euroregionów z dostępem do wody publicznej 153

7.1. Przeciętne roczne kwoty dofinansowania z Funduszu Małych Projektów oraz przeciętna roczna liczba zrealizowanych projektów w latach 2001-2013 163

7.2. Wskaźniki Perkala w euroregionach zachodniego pogranicza Polski w latach 2000 $-2014$

7.3. Postęp $w$ euroregionach zachodniego pogranicza Polski na przestrzeni lat 2000 $-2014$

7.4. Prognoza rozwoju euroregionów w latach 2015-2020

7.5. Zależność między zrównoważonym rozwojem euroregionów a przekazanym dofinansowaniem z UE

7.6. Korelacje dla wskaźnika Perkala i skumulowanych przepływów Pieniężnych z Programów EWT dla lat 2000-2014

7.7. Rozrzut pomiędzy wielkością funduszy UE a zrównoważonym rozwojem euroregionów 